\title{
FREEDOM OF INFORMATION IN THE EUROPEAN UNION
}

\author{
KUO-LIEN HSIEH
}

$\mathrm{PhD}$

The University of Edinburgh

2005 


\section{THE UNIVERSITY OF EDINBURGH}

\section{ABSTRACT OF THESIS}

Name of
Candidate: Kuo-lien Hsieh
Address:

Code:

Degree: Ph.D.

Title of

Thesis:

No. of words in the main text of $\quad 100,000$ words

Thesis:

This thesis is in three parts. The first and second parts analyse the development of the law and policy on freedom of information in the European Economic Community and European Union between 1984 and 2004. These two parts focus on how the Council, the Commission, and the Parliament enacted and implemented the rules on FOI protection, and on the role of the Community court in this field. The third part examines the roles of the European Parliament and the European Ombudsman, which have supplemented the role of the Court in securing this right. As to the objectives of this project: on the one hand, it seeks to understand the degree of legal protection offered to freedom of information in the Union over the last two decades; on the other, it seeks to identify how the current EU FOI regime could be improved. To accomplish these objectives, attention is drawn to the following interrelated issues. First of all, we consider the major controversies surrounding FOI law and policy between 1984 and 2004. In particular, this thesis focuses on the extent to which the 2001 FOI Regulation addresses the pre-existing obstacles to FOI protection. Secondly, the exceptions in Article 4(1) and Article 4(2) of the 2001 Regulation can be categorised as mandatory and discretionary respectively, but the distinction between the two provisions is vague. This indistinct dividing line should be removed to end the misunderstanding that the Council, the Commission, and the Parliament are entitled to refuse requests systematically when invoking the so-called mandatory exceptions. Thirdly, we take into account the principles established by the 2001 Regulation, the EC Treaty, or by the Court to guide the interpretation of the exceptions laid down in the Regulation. Fourthly, we argued that the EU legislator should expressly incorporate the principle of proportionality into the 2001 Regulation. Finally, we analyse recent initiatives to adopt a constitution for Europe. In the light of the "no" votes to the Treaty establishing a Constitution for Europe in the referendums in France and the Netherlands in mid 2005, further steps are now required to guarantee freedom of information in the future. 


\section{Table of Contents}

Table of Cases and Inquiries by the European Ombudsman i

Chapter 1 Introduction 1

$\begin{array}{ll}\text { PART I: } \quad \text { Initial Development } & 17\end{array}$

Chapter 2 Tentative Steps towards Freedom of Information Protection -

$\begin{array}{ll}\text { Evolution I (1984 1992) } & 17\end{array}$

Chapter 3 The Framework Established by the Code of Conduct -

Evolution II (1993 2000)

PART II: $\quad$ The Present FOI Regime in the EU: Evolution W (2001 2004) 155

Chapter 4 Article 255 EC: Implications and Limitations 157

$\begin{array}{lll}\text { Chapter } 5 & \text { Regulation EC 1049/2001 } & 176\end{array}$

PART III: $\quad$ Alternative Methods of Guaranteeing Freedom of Information

within the EU 255

$\begin{array}{lll}\text { Chapter } 6 & \text { The Role of the European Parliament } & 261\end{array}$

Chapter 7 The Role of the European Ombudsman 280

$\begin{array}{lll}\text { Chapter } 8 & \text { Conclusion } & 317\end{array}$

$\begin{array}{ll}\text { Bibliography } & 348\end{array}$

Appendix Regulation EC 1049/2001 of the European Parliament and the

Council of 30 May 2001 regarding public access to European

Parliament, Council and Commission Documents [2001] OJ

L145/43 


\section{Table of Cases and Inquiries by the European Ombudsman}

(listed chronologically)

\section{The Court of Justice}

Case 26/62, Van Gend en Loos v. Nederlandse Administratie der Belastingen [1963] ECR 1.

Case 22/70, Commission v. Council [1971] ECR 263.

Case 44/79, Liselotte Hauer v. Land Rheinland-Pfalz [1979] ECR 3727.

Case 138/79, SA Roquette Frères v. Council [1980] ECR 3333.

Case 139/79, Maizena GmbH v. Council [1980] ECR 3393.

Case 222/84, Johnston v. Chief Constable of the Royal Ulster Constabulary [1986] ECR 1651.

Case 5/88, Hubert Wachauf v. Bundesamt für Ernährung und Forstwirtschaft [1989] ECR 2609.

Case 33/88, Pilar Allué and Carmel Mary Coonan v. Università degli studi di Venezia [1989] ECR 1591.

Case C-2/88, Zwartveld and others [1990] ECR I-3365.

Case C-331/88, The Queen v. Minister of Agriculture, Fisheries and Food and Secretary of State for Health, ex parte: Fedesa and others [1990] ECR I-4023.

Case C-24/90, Hauptzollamt Hamburg-Jonas v. Werner Faust Offene Handelsgesellschaft KG [1991] ECR I-4905.

Case C-25/90, Hauptzollamt Hamburg-Jonas v. Wünsche Handelsgesellschaft GmbH \& Co. KG [1991] ECR I-4939.

Joined cases C-259/91, C-331/91 and C-332/91, Pilar Allué and Carmel Mary Coonan and others $v$. Università degli studi di Venezia and Università degli studi di Parma [1993] ECR I-4309.

Case C-58/94, Netherlands v. Council [1996] ECR I-2169.

Case C-84/95, Bosphorus Hava Yollari Turizm ve Ticaret AS v. Minister for Transport, Energy and Communications and others [1996] ECR I-3953. 
Case C-254/95P, Parliament v. Angelo Innamorati [1996] ECR I-3423.

Joined cases C 171/98 and C 189/98, Kingdom of the Netherlands and Gerard van der Wal v. Commission [2000] ECR I-0001.

Case C-353/99P, Council v. Hautala [2001] ECR I-9565.

Case C-41/00, Interporc Im- und Export GmbH v. Commission [2003] ECR I-2125.

Joined cases C-465/00, C-138/01 and C-139/01, Rechnungshof v. Österreichischer Rundfunk and others and Christa Neukomm and Joseph Lauermann $v$. Österreichischer Rundfunk [2003] ECR I-4989.

Case C-101/01, Criminal Proceedings against Bodil Lindqvist [2003] ECR I-12971.

Case C-353/01, Olli Mattila v. Council and Commission [2004] ECR I-0000.

\section{The Court of First Instance}

Case T-194/94, John Carvel and Guardian Newspapers v. Council [1995] ECR II2769.

Case T-105/95, WWF (United Kingdom) v. Commission [1997] ECR II-313.

Case T-174/95, Svenska Journalistförbundet v. Council [1998] ECR II-2289.

Case T-50/96, Primex Produkte Import-Export and Others v. Commission [1998] ECR II-3773.

Case T-83/96, Gerard van der Wal v. Commission [1998] ECR II-545.

Case T-124/96, Interporc Im- und Export GmbH v. Commission [1998] ECR II-231.

Case T-188/97, Rothmans International BV v. Commission [1999] ECR II-2463.

Case T-610/97, Carlsen and others v. Council [1998] ECR II-485.

Case T-14/98, Hautala v. Council [1999] ECR II-2489.

Case T-92/98, Interporc v. Commission [1999] ECR II-3521.

Case T-188/98, Kuijer v. Council [2000] ECR II-1959.

Case T-191/99, David Petrie, Victoria Jane Primhak, David Verzoni and Others $v$. Commission [2001] ECR II-3677. 
Case T-204/99, Olli Mattila v. Council and Commission [2001] ECR II-2265.

Case T-211/00, Aldo Kuijer v Council [2002] ECR II-485.

Case T-311/00, British American Tobacco (Investments) Ltd v. Commission [2002] ECR II-2781.

Case T-47/01, Co-Frutta Soc.coop.rl v. Commission [2003] ECR II-4441.

Case T-76/02, Mara Messina v. Commission [2003] ECR II-3203.

Case T-2/03, Verein für Konsumenteninformation v. Commission [2005] ECR II0000 .

Case T-84/03, Maurizio Turco v. Council [2004] ECR II-0000.

\section{European Court of Human Rights}

Leander v. Sweden (1987) 9 EHRR 433.

Gaskin v. United Kingdom (1989) 12 EHRR 36.

\section{The Supreme Court of Ireland}

Crotty v. An Taoiseach [1987] IR 713

\section{The European Ombudsman}

\section{Special Reports}

Special Report from the European Ombudsman to the European Parliament following the draft recommendation to the Council of the European Union in complaint 1542/2000/(PB)SM.

Special Report from the European Ombudsman to the European Parliament following the draft recommendation to the European Parliament in complaint 341/2001/(BB)IJH.

Special Report from the European Ombudsman to the European Parliament following the draft recommendation to the European Commission in owninitiative inquiry $\mathrm{OI} / 2 / 2003 / \mathrm{GG}$. 


\section{Draft Recommendations}

Draft recommendation of the European Ombudsman on the own inquiry into public access to documents (616/PUBAC/F/IJH).

Draft recommendation to the European Commission in the own initiative inquiry 1004/97/PD.

Draft recommendations to Europol in own initiative inquiry OI/1/99/IJH into public access to documents.

Draft recommendation to the Council of the European Union in complaint 573/2001/IJH.

Draft recommendation to the European Commission in complaint 1128/2001/IJH.

Draft recommendation to the European Commission in complaint 1874/2003/GG.

Draft recommendation to the European Personnel Selection Office in complaint 2028/2003/(MF)PB.

Draft recommendation to the European Personnel Selection Office in complaint 2097/2003/(ADB)PB.

Draft recommendation to the Council of the European Union in complaint 2371/2003/GG.

Draft recommendation to the European Personnel Selection Office in complaint 413/2004/(MF)PB. 


\title{
Freedom of Information in the European Union
}

\author{
1 Introduction
}

\subsection{Problematic trends}

The European Union (EU) is widely considered to be insufficiently democratic, a concern neatly highlighted by the phrase "democratic deficit". ${ }^{1}$ The EU's lack of democracy can be analysed from various perspectives, but previous research on this phenomenon has very much focused on the policy and rule making of the EC institutions. ${ }^{2}$ The issue of freedom of information does, however, deserve particular attention as failure to secure this right has a negative impact on the democratic nature of the Union. This is especially so, given the proposition that citizens should have a

\footnotetext{
${ }^{1}$ T. Hartley, Constitutional Problems of the European Union (Oxford, Oxford University Press, 1999), 18; P. Birkinshaw, Freedom of Information, The Law, the Practice and the Ideal ( $3^{\text {rd }}$ edn., London, Butterworths, 2001), 1. Democratic deficit refers broadly to the belief that the Union lacks sufficient democratic control. L. Dobson and A. Weale, 'Government and Legitimacy,' in E. Bomberg and A. Stubb (eds.), The European Union: How Does it Work? (Oxford, Oxford University Press, 2003), 157.

${ }^{2}$ For instance, many community experts have long been interested in the operation of the European Parliament and European Commission. Several writers have pointed out that the Community has no government or opposition which can be held directly accountable for the EU's action. Hartley, n. 1 above, at 19, and Dobson and Weale, ibid. Some commentators consider the Commission the government of the community, but it is not a party government. No political party is responsible for the policies proposed by the Commission as no party holds power. Secondly, some political analysts originally thought that the problem of the democratic deficit would be solved as soon as the European Parliament was directly elected by the European citizens. Nevertheless, the Parliament gave the Community little more than a façade of democracy, because the directly-elected Parliament had initially limited control over the legislative process, though its position has been enhanced by procedural changes introduced by the Maastricht and Amsterdam revisions to the Treaty of Rome: the co-decision procedure introduced under Article 251 (ex Article 189b) EC. Thirdly, the excessive secretiveness in the Council is also a major cause of the democratic deficit. This institution's lack of openness has a negative impact on the EU citizens' freedom of information, which will be examined in detail in later chapters.
} 
right to information held by their governments has at present been recognised within liberal democracies, such as Sweden, the U.S.A., and the U.K., which have adopted statutes to realise freedom of information.

At least two factors, other than the respective roles and operation of the EU institutions, have led to the democratic deficit displayed by the Union in its practices. First, the origin of the Union as an international organisation has ensured that secrecy and sensitivity attended its diplomatic relations. The European enterprise began on 18 April 1951 when three large Member States and three small ones met in Paris to sign the Treaty establishing the European Coal and Steel Community, which was the result of the "Schuman Plan". ${ }^{3}$ French Foreign Minister, Robert Schuman, emboldened by Jean Monnet's suggestion and by the swing in official French opinion towards an economic accord with Germany, floated the proposal with secrecy and speed. Before the plan was revealed to the public, Mr. Monnet and Mr. Schuman clandestinely obtained approval from three key parties: the French, German, and U.S. governments. ${ }^{4}$ As regards policy-making within the ECSC, the ECSC Treaty did not state that the highest decision-making body, namely the High Authority, was entitled to operate in absolute secrecy. However, the High Authority consisting of nine members, most of whom were appointed by the Member States, was allowed to make various arrangements for the operation of its departments, according to Articles 9(1), 10(1), and 16(1) of the ECSC Treaty. ${ }^{5}$ Such information

\footnotetext{
${ }^{3}$ The three large Member States are Germany, France, and Italy, and the three small ones are Belgium, the Netherlands, and Luxembourg. This Treaty entered into force on 25 July 1952.

${ }^{4}$ D. Dinan, Ever Closer Union? An Introduction to the European Integration $\left(2^{\text {nd }}\right.$ edn., Basingstoke, Macmillan, 1999), 21-22, and sources there cited.

${ }^{5}$ Article $9(1)$ of the ECSC Treaty provides that "[t]he High Authority shall consist of nine members appointed for six years and chosen on the grounds of their general competence", while Article 10(1) states that "[t]he Governments of the Member States shall appoint eight members of the High Authority by common accord. These eight members shall appoint the ninth member, who shall be duly elected if he receives at least five votes". Under Article 16(1) of this Treaty, that "[t]he High Authority shall make all appropriate administrative arrangements for the operation of its departments"
} 
as was to be made available to the public was merely a sketchy description of the activities and the administrative expenditure of the ECSC, under Article 17 of the ECSC Treaty. ${ }^{6}$ Whatever Community jurists may say of its present nature, the EU's origin ensured that maximum secrecy would attend the political relationships between the Member States.

Second, the lack of a European identity among the population also poses a dilemma for European democracy. Democracy, which means popular sovereignty and implies the existence of a people, a demos, depends on a sufficient number of individuals feeling that they belong to the same political community. Democracy presupposes that most members of the electorate think of other voters in some sense as "one of us". The feeling of belonging to the same community is often expressed by terms such as "one nation". However, originally only the Member States rather than individuals played a role in the Community, though it is possible to see greater status afforded to the individual within the EU system through the introduction of direct elections and the concept of EU citizenship. Despite this, EU citizens, drawn from a number of separate nations, have only a limited sense of being European. ${ }^{7}$

Easier access to information from public authorities would help European citizens become familiar with the operation of the Union and assist them in participating in decision-making. In other words, the right to information is undoubtedly an essential part of the democratisation of the EU administration.

The foundation of freedom of information concerns the democratic principle

(emphasis added).

${ }^{6}$ Article 17 of the ECSC Treaty states that "[t]he High Authority shall publish annually, not later than one month before the opening of the session of the Assembly, a general report on the activities and the administrative expenditure of the Community". The Assembly refers to the Common Assembly, the precedent of the European Parliament.

${ }^{7}$ Hartley, n. 1 above, at 20; I. Harden, 'Citizenship and Information' (2001) 7 European Public Law 184. 
which has both "affirmative" and "critical" aspects. The affirmative aspect of democracy is that popular sovereignty is the source of authority to create and enforce obligations on citizens. The critical aspect, on the other hand, questions, limits and constrains public power. ${ }^{8}$ Freedom of information is based on the latter but also has a link to the former. Professor Ian Harden says that "[t]he right [to call public authorities to account] cannot be exercised effectively without access to information about what the public authorities are doing and why. Public access enables citizens to scrutinise the activities of those exercising public authority and to make an independent evaluation of them". ${ }^{9}$ Elaborating on the functions of this freedom, Professor Patrick Birkinshaw notes that "[f]reedom of information does not mean access to brute information alone such as documents or records in whatever form, as we shall see. It leads into open government in so far as it necessitates access to governmental decision-making in a more participatory form. The claims are couched in terms of a right to know, a democratic right" ${ }^{10}$ The issues concerning access to the documents produced for decision-making of the EU authorities fall within the scope of this study. It does not, however, seek to consider generally all the issues regarding decision-making processes in the Union. ${ }^{11}$

The issues relating to FOI protection were almost completely neglected by Community jurists and the Community administration, prior to the initial defeat of

\footnotetext{
${ }^{8}$ Harden, n. 7 above, at $184-185$.

${ }^{9}$ Harden, n. 7 above, at 185 .

${ }^{10}$ Birkinshaw, n. 1 above, at 28.

1 Some academic writers have considered generally the major issues concerning decision-making in the Union, which closely relate to a broad and ever-expanding concept of "accountability". A. Arnull and D. Wincott (eds.), Accountability and Legitimacy in the European Union (Oxford, Oxford University Press, 2002); C. Harlow, Accountability in the European Union (Oxford, Oxford University Press, 2002); D. Curtin, 'Delegation to EU Non-Majoritarian Agencies and Emerging Practices of Public Accountability,' in D. Geradin, R. Munoz, and N. Petit (eds.), Regulation through Agencies: a New Paradigm of European Governance (Cheltenham Glos, Edward Elgar Publishing, 2005), 1-32.
} 
the Treaty of Maastricht in June 1992 in Denmark, and its narrow approval in France three months later. ${ }^{12}$ During the early days of the history of European integration, the discordance between the expectation of freedom of information and the secretiveness of the Union did not lead to a "crisis of legitimacy". The difficulties encountered in adoption of the Maastricht Treaty, nevertheless, revealed the huge gap that existed between European citizens and the high-ranking officials which governed them. In the early 1990s, as Professor Desmond Dinan has said, "[t]he Council seemed secretive and self-serving, the Commission remote and technocratic, and the EP expensive and irrelevant". ${ }^{13}$ The challenge encountered in obtaining the citizens' approval was attributable to the lack of information which citizens had about the Treaty and the proposed change to the EC at that time. The citizens of the Member States apparently felt that they were alienated from a complex system of governance, which was based on unelected institutions, perceived as remote and inaccessible owing to lack of participation.

Granting freedom of information to citizens in the Member States has played a crucial role in improving the EU's imperfect democratic order, especially following the accession of two Nordic countries, Sweden and Finland, in 1995. As Professor Inger Österdahl records, upon Sweden's entry into the Union, many Swedish people feared that their domestic legislation on openness would not survive EU membership, because Community law at that time allowed for far less openness in certain areas than Swedish law. ${ }^{14}$ Throughout this thesis, references are made to relevant FOI initiatives in other countries, particularly those in the EU, where there is a great

12 Denmark rejected ratification of the Maastricht Treaty by referendum on 2 June 1992. A referendum in France ratified this Treaty on 20 September 1992 by only 50.4 percent to 49.4 percent.

${ }_{13}^{13}$ Dinan, n. 4 above, at 152.

${ }^{14}$ I. Österdahl, 'Openness v. Secrecy: Public Access to Documents in Sweden and the European Union' (1998) 23 European Law Review 336. 
diversity of cultures of openness. The focus of this thesis is, however, on the development of FOI law in the EU and how this can be improved, and, given the present word constraints, it has not been possible to do more than touch on these issues.

\subsection{Scope of freedom of information}

For many who employ the phrase freedom of information, it means having access to government documents or information in any other form in order better to understand the policies of the government. In some jurisdictions, it means not only allowing access to files in whatever form they exist, but also opening up the meetings of governments, their advisory bodies and client groups to public scrutiny. Alternatively, it may involve access by individuals to files containing information about them - and an assurance that such information is not being used for improper or unauthorised purposes. $^{15}$

The term "transparency" has been frequently employed in the language of the institutions to refer to openness in the working of the Community institutions. "It is linked to a variety of demands for broader public access to information and EU documents and more easily readable instruments (simplification of the Treaties, consolidation and better drafting of legislation)". ${ }^{16}$ Complaints regarding lack of transparency, "tend to reflect a general feeling that the European institutions are remote and secretive and that decision-making procedures are difficult for the

\footnotetext{
${ }^{15}$ Birkinshaw, n. 1 above, at 1.

${ }^{16}$ This definition is available at the section entitled "Glossary" of Europa, the EU's portal website, http://www.europa.eu.int/scadplus/leg/en/cig/g4000t.htm\#t4
} 
ordinary European citizen to understand". ${ }^{17}$ This definition indicates that transparency, a central theme in the EU administration, has a wider reach than freedom of information. ${ }^{18}$

Freedom of information may, in turn, be seen as wider ranging than another commonly used phrase, "open government", in so far as the former covers potentially all information in the public and private domain. The two terms are not absolutely the same though very closely related. This study concentrates on the latter, which refers to openness of processes, as well as documentation, in the field of governmental decision making, and may concern private institutions in so far as they are used as a surrogate for such decision-making. ${ }^{19}$

\subsection{Structure}

This project has three main parts. My objectives in this study will be to:

(1) Set out and explain the key Community regulatory provisions in this field noting, in particular, the range of information covered and scope

\footnotetext{
${ }^{17}$ Ibid.

${ }^{18}$ Professor Deidre Curtin has also said that "[t]ransparency refers not only to access to government-held information by individuals and legislative assemblies (both the European Parliament and the national parliaments), but also, more widely, to open government as such (the question of opening up meetings, rule-making proceedings and governmental deliberations to the public)". D. Curtin, "Civil Society' and the European Union: Opening Spaces for Deliberative Democracy?,' in Academy of European law (ed.), Collected Courses of the Academy of European Law vol. VII, Book 1 (The Hague, Kluwer Law International, 1999), 250. See also C. Harlow, "Freedom of Information and Transparency as Administrative and Constitutional Rights," in A. Dashwood and A. Ward (eds.), Cambridge Yearbook of European Legal Studies vol. II (Oxford, Hart Publishing, 2000), 285-286. It bears noting that the scope of transparency has not yet been fully crystallised. However, some academic writers have made attempts to identify its elements. For instance, Dr. Linda Senden discusses Articles 253-255 EC and the principle of certainty when she considers the principle of transparency. L. Senden, Soft Law in European Community Law (Oxford, Hart Publishing, 2004), 96-104.

${ }^{19}$ Birkinshaw, n. 1 above, at 27-28
} 
of any exceptions to openness.

(2) Assess the effectiveness of the procedures for obtaining information, in particular, the availability of information concerning what is available, for example, through a register of documents, and enforcement mechanisms. In addition, issues concerning the availability of appeal procedures and the EC institutions' duty to provide reasons for refusals to grant information will also be analysed.

(3) Examine the role of the Community courts in interpretation and enforcement of the above mentioned provisions.

(4) Focus on the roles of the European Parliament and the European Ombudsman in EU FOI protection, which offer alternative mechanisms for enforcing transparency and openness of the EU institutions, agencies, and bodies. The Parliament and Ombudsman have long employed a number of measures, such as inquiries and petition procedures, in order to safeguard freedom of information in the Union.

Chapters 2 to 5 examine the evolution of freedom of information legislation and policy in the Union. The Union, which at present commits itself to giving "the fullest possible effect to the right of public access to documents and to lay down the general principles on such access", ${ }^{20}$ does not have a long history of active steps to protect the right to information. ${ }^{21}$ The evolution of policies and legislation in this field can be divided into three stages. The first stage, from 1984 to 1992 , dealt with in Chapter

\footnotetext{
${ }^{20}$ Regulation EC 1049/2001 of the European Parliament and the Council of 30 May 2001 regarding public access to European Parliament, Council and Commission Documents [2001] OJ L145/43.

${ }^{21}$ Professor Curtin also said in 1999 that " $[\mathrm{t}]$ he topic of transparency, in the sense of the openness of the EU legislative process, was until a couple of years ago a virtual non-subject". Curtin, n. 18 above, at 250 .
} 
2, was a phase of tentative steps towards openness. The European Parliament adopted an initial resolution on access to Community information in $1984 .^{22}$ Four years later, it adopted another resolution, ${ }^{23}$ as neither the Commission nor the Council took action to make information in the Community more accessible to the public. The most significant initiative of the Commission on the subject during this period, namely its proposal for a draft directive on the freedom of access to information on the environment, ${ }^{24}$ will be examined. In addition, the 1990 Zwartveld judgment concerning conflicts between secrecy within the Commission and freedom of information will also be analysed. ${ }^{25}$ Policy governing freedom of information in the Union was born out of a deep crisis of legitimacy which threatened the integration of Europe in the late 1980s and early 1990s. Our analysis indicates that both the public and the EC institutions can, therefore, be considered victims of the absence of FOI legislation at this first stage of the FOI evolution.

Attention then focuses on the policies and legislation made between 1993 and 2000, principally the 1993 Code of Conduct and corresponding Council Decision 93/731 and Commission Decision 94/90, in response to the legitimacy crisis. ${ }^{26}$ This constitutes the second phase of Community involvement in this field. The Code of Conduct, the two decisions, and court rulings relating to these three measures, are

${ }^{22}$ Resolution on the compulsory publication of information by the European Community [1984] OJ C172/176.

${ }^{23}$ Resolution on the compulsory publication of information by the European Community [1988] OJ C49/174.

${ }^{24}$ Proposal for a Council Directive on the freedom of access to information on the environment [1988] OJ C355/5. The Council of Ministers adopted the Directive (90/313/EEC [1990] OJ L158/56), which entered into force on 1 January 1993. A decade later, the Parliament and the Council adopted a new Directive on access to environmental information. Directive 2003/4/EC of the European Parliament and of the Council of 28 January 2003 on public access to environmental information and repealing Council Directive 90/313/EEC [2003] OJ L41/26.

${ }_{25}$ Case C-2/88 Imm, Zwartveld and others [1990] ECR I-3365.

${ }^{26}$ The Code of Conduct concerning public access to Council and Commission documents (93/730/EC) [1993] OJ L340/41. Council Decision of 20 December 1993 on public access to Council documents (93/731/EC) [1993] OJ L340/43, and Commission Decision of 8 February 1994 on public access to Commission documents (94/90/ECSC, EC, Euratom) [1994] OJ L46/58. 
examined in detail in Chapter 3. First of all, we concentrate on the legal rules or principles employed by applicants and the Court to interpret narrowly the exceptions set out in the Code of Conduct and the corresponding Council and Commission decisions. In particular we can see that:

(1) The CFI stressed the importance of the principle of "widest possible access" set out in the first section of the Code of Conduct.

(2) Section 4, subsection 2 of the Code of Conduct was held by the Court to require a balancing test. The CFI elaborated on the balancing test and repeatedly emphasised its importance.

(3) The CFI stressed that the Commission, in refusing access to the documents sought, should have provided sufficient reasons as required by Article 190 (now Article 253 EC). ${ }^{27}$ Nonetheless, the CFI has not adopted a consistent approach when interpreting the term "sufficient reasons" and "adequate reasoning".

(4) The CFI introduced the principle of proportionality into the EU FOI field.

Secondly, the Council and Commission between 1993 and 2000 tended to refuse applications systematically, which indicated that the two institutions held to the view that secrecy ought to be the rule and openness the exception. Thirdly, there seemed to be a clear distinction between the two categories of exceptions set out in the Code of Conduct. The first category of exceptions appeared to be mandatory and the other

\footnotetext{
${ }^{27}$ Former Article 190 EC provides that "[r]egulations, directives and decisions adopted jointly by the European Parliament and the Council, and such acts adopted by the Council or the Commission, shall state the reasons on which they are based and shall refer to any proposals or opinions which were required to be obtained pursuant to this Treaty".
} 
discretionary. ${ }^{28}$ However, the judgments delivered by the Courts between 1995 and 2001 indicate that the distinction between these two provisions is not at all distinct.

Towards the end of the second stage, the Amsterdam Treaty, signed in June 1997, explicitly acknowledged a right of access to documents held by the EU institutions. It directed that an implementing regulation should be adopted within two years of the entry into force of the Treaty. The European Parliament and the Council adopted a new regulation in May 2001, ${ }^{29}$ which came into effect the following December, marking the start of the third stage. Chapter 5 analyses the 2001 Regulation, its implementation, and relevant court decisions. In particular, it considers whether the Union has now done enough to meet the demands for more openness or, alternatively, whether it has achieved only partial success. Professor Ian Harden said in 2001 that "[w]hen the (2001) public access Regulation is implemented, it should significantly enhance the openness of the European Union". 30 Meanwhile, Professor Patrick Birkinshaw observed that the general feeling was that the European Parliament had done well to see through its major proposals on the subject, though certain parties were still disappointed by some of the concessions on "sensitive" documents. ${ }^{31}$

The steps taken by the EU do seem significant. Nonetheless, this thesis analyses the 2001 Regulation in more detail to ascertain which of the provisions could, or indeed are, proving problematic for freedom of information. We consider not only

\footnotetext{
${ }^{28}$ As to the first category of exceptions, section 4, subsection 1 of the Code of Conduct stated that, the Council and the Commission "will refuse access to any document whose disclosure could undermine" the protection of certain public interests, as well as privacy, and commercial secrecy, etc. According to section 4, subsection 2 of the Code of Conduct, the two institutions "may also refuse access in order to protect the institution's interest in the confidentiality of its proceedings", n. 26 above.

${ }^{29}$ n. 20 above.

${ }^{30}$ Harden, n. 7 above, at 193 .

${ }^{31}$ Birkinshaw, n. 1 above, at 484.
} 
the provisions of the 2001 Regulation and the relevant judgments, but also the influence of established administrative attitudes and norms about the confidentiality of interstate communications, which could have a significant impact on how the rules operate in practice and which could even trump demands for freedom of information. By the end of December 2004, the most important policy documents were:

(1) Council Annual Reports on Access to Documents for 2002 and 2003; ${ }^{32}$

(2) Reports from the Commission on the Application in 2002 and 2003 of the 2001 Regulation; ${ }^{33}$

(3) Report from the Commission on the Implementation of the principles in the 2001 Regulation. ${ }^{34}$

In addition, the Court of Justice has continued to make a contribution to the law and has made a number of important rulings following the entry into force of the 2001 Regulation. These judgments are considered in detail in Chapter 5. Although many of these concern the earlier Code of Conduct and linked decisions, they are of interest because they may suggest how the Court will rule on, in some circumstances closely analogous, provisions in the 2001 Regulation. What do these judgments mainly indicate?

32 The Council, Council Annual Report on Access to Documents - 2002 (Brussels, the Council, April 2003), http://register.consilium.eu.int/utfregister/frames/introfsEN.htm; The Council, Council Annual Report on Access to Documents - 2003 (Brussels, the Council, April 2004), http://ue.eu.int/uedocs/cmsUpload/RapAnCons.en03.pdf

${ }^{33}$ The European Commission, Report from the Commission on the Application in 2002 of Regulation (EC) No 1049/2001 of the European Parliament and of the Council regarding Public .1ccess to European Parliament, Council and Commission documents, COM(2003) 216 final, (Brussels, European Commission, 29 April 2003), http://europa.eu.int/smartapi/cgi/sga_doc?smartapi!celexapi!prod!CELEXnumdoc\&lg=EN\&numdoc=520 03DC0216\& model-guichett; The European Commission, Report from the Commission on the Application in 2003 of Regulation (EC) No 1049/2001 regarding Public Access to European Parliament, Council and Commission documents, $\operatorname{COM(2004)~} 347$ final, (Brussels, European Commission, 30 April 2004), http://europa.eu.int/eur-lex/lex/LexUriServ/site/en/com/2004/com2004_0347en01.pdf

${ }_{34}$ European Commission, Report from the Commission on the Implementation of the principles in EC Regulation No 1049/2001 regarding Public Access to European Parliament, Council and Commission Documents, COM(2004)45 final, (Brussels, European Commission, 30 Jan. 2004), http://europa.eu.int/eur-lex/en/com/rpt/2004/com2004_0045en01.pdf 
(1) The CFI stressed that the Council and Commission were obliged to consider the principle of proportionality when they refused access to documents on the basis of protecting international relations. However, it remains uncertain whether an institution bears the same duty when invoking any of the other exceptions as the basis for a refusal.

(2) The issues relating to the authorship rule became extremely contentious after the 2001 Regulation came into effect. The case law indicates that this rule ran counter to the principle of widest possible access set out in the Code of Conduct. ${ }^{35}$ In particular, the CFI regarded the reference to the authorship rule to provide a sufficiently clear basis for a refusal of access and to be in conformity with the duty to give reasons in Article 253 EC.

(3) Article 4(5) of the 2001 Regulation or the so-called "non-disclosure rule", which can be regarded as a "Member State" exception, differs significantly from the authorship rule set out in the Code of Conduct. ${ }^{36}$ Under Article 4(5), the Council, the Commission, and the Parliament are not bound by the requests from the Member States, but the CFI has not paid sufficient attention to this important feature. The invocation of this highly controversial provision is expected to trigger ongoing debate.

(4) As regards the public interest exceptions relating to investigations, inspections, and court proceedings set out in the Code of Conduct, as

\footnotetext{
${ }^{35}$ The authorship rule provides that "[w] here the document held by an institution was written by a natural or legal person, a Member State, another Community institution or body or any other national or international body, the application must be sent direct to the author".

${ }^{36}$ Article 4(5) states that "[a] Member State may request the institution not to disclose a document originating from that Member State without its prior agreement".
} 
well as the two corresponding decisions, the case law indicates that the purpose behind these exceptions was unclear.

Part I and Part II of this thesis examine both the relevant implementing measures adopted by the EU institutions and the disputes concerning freedom of information which have come before the ECJ and CFI to date. A key question which underlies this analysis is whether the judicial institutions of the Community were able to develop appropriate guidelines in this area and make significant inroads into secrecy. Generally, the Court has made a considerable contribution to FOI protection in the Union. It has not, however, adopted a consistent approach when applying legal rules or principles, such as the balancing test and the principle of proportionality, to counter systematic refusals of access to information.

The EU experience of reform gave cause for optimism because it led to the adoption of new treaty provisions and the Code of Conduct, two corresponding Council and Commission decisions, as well as the 2001 Regulation, which appeared to have improved the EU imperfect democratic order. But does the EU truly recognise freedom of information as a fundamental right? Or does it take advantage of this right instrumentally for political objectives, in particular, to strengthen public confidence in the Union? The significant body of case law, which highlights problems with the operation of the right of access, indicates that the Council and Commission have been systematically refusing access to information by invoking certain exceptions. To reduce such refusals, we suggest that the EU legislator include an explicit reference to the principle of proportionality in the 2001 Regulation. This proposed provision requires that (A) the proportionality test be applied when any of the exceptions set out in the Regulation are invoked, and (B) the way this test is 
applied in any given cases should be expressly indicated in the refusal.

The third part (Chapters 6 and 7) of this study concentrates on the roles of the European Parliament and Ombudsman in this field. The Ombudsman's functions and findings deserve specific attention, as the institution has long been active in influencing other institutions and bodies and has made a considerable contribution in this field. As Professor Patrick Birkinshaw has said, "[t]he Ombudsman has in fact attacked secrecy in the EU with missionary zeal. All institutions not covered by the Code [of Conduct], including the court, eventually accepted that they should adopt their own practices in relation to access which were based on the Code. Without such a practice, they would run the risk of being found guilty of maladministration". ${ }^{37}$

The eighth and final chapter pulls together the conclusions reached in the previous chapters and makes a number of proposals for reform of the existing law. First of all, it re-evaluates the remarkable changes in position of the Council and the Commission towards FOI protection. It also looks at the case law and annual reports which demonstrate the institutions' overbroad interpretation of the public interest exceptions relating to inspections, investigations, court proceedings, and of the authorship rule. Second, this chapter considers how such controversies might be reduced and focuses, in particular, on how the role played by the principle of proportionality could be enhanced. In the final section of this chapter, we consider what we can learn from recent initiatives to adopt a constitution for Europe. In the light of the "no" votes to the Treaty establishing a Constitution for Europe in the referendums in France and the Netherlands in mid 2005, what further steps are

\footnotetext{
${ }^{37}$ Birkinshaw, n. 1 above, at 368-369, and reference there cited. The Ombudsman also boasted that his inquiries on public access to EU documents "led almost all the Community institutions and bodies to adopt and publish rules on access". European Ombudsman, What can the European Ombudsman Do for You (Strasbourg, European Ombudsman, 2002), 15.
} 
required to guarantee freedom of information? We argue that collaborative efforts to secure freedom of information by the Commission, the Council, the Parliament, the Court, and the Ombudsman will continue to be essential in the future. 


\section{PART I \\ Initial Development}

2

\section{Tentative Steps towards Freedom of Information Protection - Evolution I (1984 1992)}

\subsection{Resolutions adopted by the Parliament}

Some writers argue that policy governing access to information in the EU institutions was born out of a crisis of legitimacy that confronted the project of European integration in the late 1980s and early 1990s. ${ }^{1}$ Nonetheless, the European Parliament started to work out its policy on freedom of information as early as the first half of the 1980s. It became the first Community institution to show an interest in this area when it adopted a Resolution on 24 May 1984, some eight years before the Treaty on the European Union was signed in Maastricht. ${ }^{2}$ This Resolution is the first measure

\footnotetext{
' A. Roberts, 'Multilateral Institutions and the Right to Information: Experience in the European Union' (2002) 8 European Public Law 258. Professor Emmanuel Paraschos has also said the EU did not start to focus on its information policies until the Maastricht Treaty began to face serious questions both before and after its signing in December 1991 and February 1992. E. Paraschos, Media Law and Regulation in the European Union, National, Transnational and U.S. Perspectives (Armes, Iowa State University Press, 1998), 116.

${ }^{2}$ Resolution on the compulsory publication of information by the European Community [1984] OJ
} 
in the Community calling for introduction of legislation on freedom of information, though few have discussed the plan revealed in this Resolution to ameliorate the Community democratic order. ${ }^{3}$ The first directly elected Parliament adopted this Resolution, ${ }^{4}$ one month before the second elections and three months after it passed the "Draft Treaty Establishing the European Union", a proposal of decision-making reform designed to improve efficiency and to close the democratic deficit. ${ }^{5}$

The Parliament, according to this Resolution, considered that "the European Community should have its own legislation on openness of government of Community affairs", and instructed its President to call on the newly elected Parliament at that time to press for the drafting of legislation on this matter. The Parliament also considered that activities of the various Community institutions "should be expanded so as to satisfy the information requirements of European citizens to an even greater extent". This Resolution indicated that the Parliament, whose members had been elected by direct universal suffrage since 1979 , realised in the early 1980 s that there was an urgent need for more openness.

Although the Parliament pointed out that the Community should have its own

\footnotetext{
C172/176.

${ }^{3}$ Many writers ignore this Resolution in their discussion of Community FOI evolution. A few others realise that the Parliament showed an interest in the subject for the first time when adopting this Resolution. Professors Deirdre Curtin and Herman Meijers said in 1995 that the Parliament showed a pioneering interest in freedom of information more than a decade ago and adopted the Resolution in 1984, calling for the introduction of the legislation. D. Curtin and H. Meijers, 'Access to European Union Information: an Element of Citizenship and a Neglected Constitutional Right' in N. Neuwahl and A. Rosas (eds.), The European Union and Human Rights (The Hague, Martinus Nijhoff, 1995), 81. In addition, Professor Michael O'Neill also says that the Parliament, on its crusade to redress the democratic deficit, had sought to place the general issue of access to information on the Community agenda, with the adoption of its Resolution on the compulsory publishing of information in 1984. M. O'Neill, 'The Right of Access to Community - Held Documentation as a General Principle of EC Law' (1998) 4 European Public Law 407-408. Unfortunately, these two articles do not touch on the proposal set out in this first measure in the Community FOI field.

${ }^{4}$ The first directly elected Parliament, which lacked influence, wished to revive the process of European integration. Between April 1980 and February 1982, the Parliament passed no less than eight Resolutions advocating institutional and policy reform in the Community. D. Dinan, Ever Closer Union, An Introduction to European Integration ( $2^{\text {nd }}$ edn., Basingstoke, Macmillan Press, 1999), 98. ${ }^{5}$ Ibid.
} 
FOI legislation, neither the Council nor the Commission took action in response. In another attempt to create a more open Community, the Parliament adopted a further Resolution on access to Community information on 22 January $1988,{ }^{6}$ seven months after a United Kingdom (and Irish) citizen raised the issue of the compatibility of the SEA provisions on political cooperation with the policy of neutrality long pursued by Ireland. $^{7}$ The difficulty in ratification of the Single European Act signed in 1986 gave intimation of the potential troubles if public opinion was ignored.

The Parliament, according to the 1988 Resolution, regretted that the Council and the Commission had failed to act in response to the 1984 Resolution. The Parliament said that "the right to information is one of the fundamental freedoms of the people of Europe and that it should be recognised as such by the European Community". This was the first time that a Community institution expressly stated that this right should be regarded as a fundamental right, though this right was at most an aspiration in the Community at that time.

The Parliament urged the Commission to draw up a proposal for Community legislation on access to information on Community administrative measures. It also worked out a framework for the future legislation. According to the Resolution:

The European Parliament hopes that this legislation will contain a precise definition of the nature and scope of the right to information, the exemptions on the grounds of confidentiality, the description of documents intended for internal use, the procedure for publication of the documents and administrative measures covered by this legislation, the settlement of any disputes and the

\footnotetext{
${ }^{6}$ Resolution on the compulsory publication of information by the European Community [1988] OJ C49/174.

${ }^{7}$ The Supreme Court of Ireland ruled (Crotty v. An Taoiseach [1987] IR 713) that, in accordance with the Constitution, Irish ratification could proceed only following a positive result in a national referendum. In May 1987 a healthy majority (69.9 percent against 30.1 percent) supported the necessary amendment.
} 
penalties for failure to comply with the legislation.

The Parliament drew up a framework for the legislation and realised what could be the most controversial issues in the future. To make the decision-making procedure of the Council accessible to the public, the Parliament, according to the Resolution, "requests that the minutes of Council meetings which concern the discussion of and decision-making on a regulation or directive should be published, including the statements which alter the purpose of the directive or give another interpretation to the published document".

The Parliament also "wishes to see open access to information concerning the activities of the management and the advisory committees, with a view to obtaining precise information on the scope of the decisions taken". The Parliament believed that the operation of not only the Council but also the advisory committees should be available to the public, or citizens in the Community would only be able to access incomplete information about the decision-making. The advisory committees are known as "comitology committees". Most decisions at EC level are purely administrative and concern the implementation of various policies. The Commission has primary responsibility for such decisions, but a complicated committee procedure exists under the name of comitology, which allows national officials to monitor the execution of the policies. ${ }^{8}$ The Commission has expressed little enthusiasm for improving transparency by allowing access to records of comitology committees. Commentators have jokingly said what is clear is that "the only person who truly understands [comitology] is the doorman at 35 Avenue Brochart in Brussels (the venue for most meetings) who can survey the hundreds of national and EU

\footnotetext{
${ }^{8}$ A. Stubb, H. Wallace, and J. Peterson, 'The Policy-Making Process' in E. Bomberg and A. Stubb (eds.), The European Union: How Does it Work? (Oxford, Oxford University Press, 2003), 142.
} 
bureaucrats and experts walking in and out of comitology meetings on a daily basis". ${ }^{9}$

The adoption of the two Resolutions indicated that the Parliament had laboured during the 1980 s to supply the citizens in the Community with more freedom of information, but the content of the Resolutions was merely aspirational owing to their unclear legal effects. Article 249 EC (former Article 189 EC) lists five categories of acts that may be adopted by the Parliament and the Council acting jointly, by the Council, or by the Commission, three of which - regulations, directives and decisions - are usually binding. ${ }^{10}$ Resolutions such as the two adopted by the Parliament are, however, a different kind of measure and are not specially mentioned in Article $249 \mathrm{EC}$, though they perform a similar function to non-binding recommendations and opinions. They can be adopted by the Parliament, the Commission, or by the Council, but they are not readily capable of inclusion in the forms set out in Article 249 EC. Such measures, which are listed as one form of action for forming and shaping the legal order in the Community, are within the categnry of sui generis acts ${ }^{11}$ Resolutions only set out the views and intentions of an

\footnotetext{
${ }^{9}$ Ibid.

${ }^{10} \mathrm{Article} 249 \mathrm{EC}$ lists five kinds of acts and contains a description of the characteristics they have. It states that:

In order to carry out their task and in accordance with the provisions of this Treaty, the European Parliament acting jointly with the Council, the Council and the Commission shall make regulations and issue directives, take decisions, make recommendations or deliver opinions.

A regulation shall have general application. It shall be binding in its entirety and directly applicable in all Member States.

A directive shall be binding, as to the result to be achieved, upon each Member State to which it is addressed, but shall leave to the national authorities the choice of form and methods. A decision shall be binding in its entirety upon those to whom it is addressed. Recommendations and opinions shall have no binding force.

${ }^{11}$ Resolutions fall within the category of sui generis acts, but they only have vague characteristics. J. Shaw, Law of the European Union ( $3^{\text {rd }}$ edn., Basingstoke, Palgrave, 2000), 247. In Case 22/70, Commission v. Council [1971] ECR 263, the Court stated that "[u]nder Article 173, the Court has a duty to review the legality of acts of the Council ... other than recommendations or opinions". Professor Trevor Hartley says that Article 249 EC appears to form a neat and tidy system in which formal designations correspond to differences in function. The differences suggest a hierarchy.
} 
institution regarding the overall process of integration and specific tasks within and outside the Community. ${ }^{12}$ Thus, the two Resolutions adopted in 1984 and 1988 by the Parliament, whose legal effects were not as intense as regulations, directives, or decisions, were tentative steps towards FOI protection, in contrast to the more concrete measures taken by the EC institutions following the Maastricht Treaty.

The Parliament in the two Resolutions called on the Commission to draw up a proposal for Community legislation on access to information on Community administrative measures, but the Commission only worked out a plan concerning access to environmental information rather than regarding all administrative acts.

\subsection{The Commission initiative}

The Commission in October 1988 submitted to the Council a proposal for a Council Directive on the freedom of information on the environment. ${ }^{13}$ Article 1 of the proposal stated that "[f]reedom of access to information on the environment held by the public authorities and its dissemination shall be ensured throughout the Community in accordance with the provisions of this Directive". Such information, however, could never be "ensured throughout the Community" because the term

\footnotetext{
Nevertheless, one of the major complications is that resolutions do not fall into any of the categories enumerated in Article 249 EC. T. Hartley, The Foundations of European Community Law $\left(5^{\text {th }}\right.$ edn., Oxford, Oxford University Press, 2003), 104. Dr Klaus-Dieter Borchardt has said that "the primary significance of resolutions is that they help to give the Council's future work a political direction. ... Any assessment of [resolutions'] legal significance must also take account of these functions, i.e. they should remain a flexible tool and not be tied down by too many legal requirements and obligations". K.-D. Borchardt, The ABC of Community Law ( $5^{\text {th }}$ edn., Brussels, European Commission, 2000), 71.

${ }_{12}$ Borchardt, n. 11 above, at 71.

${ }^{13}$ Proposal for a Council Directive on the freedom of access to information on the environment [1988] OJ C355/5.
} 
"public authorities", according to paragraph 1 of Article 2(c), "means State administrations and any public body or State-supervised body with powers at national, regional or local level". These rules were not intended to apply to the Community institutions. In addition, “[b]odies exercising judicial powers or legislative bodies", according to paragraph 2 of Article 2(c), were not required to make the information in their possession available to the public.

This plan revealed that the Commission was generous in making Member State information available to the public but declined to show the same generosity of spirit when addressing its own or any other institution's information. The Commission later decided to consult the European Economic and Social Committee, the non-political organisation which had long been the only consultative body in the Community that provided not only the Commission but also the Parliament and the Council with views of the people in Member States. ${ }^{14}$ This Committee adopted an opinion on the proposal, disagreeing with the Commission's reluctance to work out draft legislation on environmental information it held. ${ }^{15}$ The Committee said that:

The draft Directive's scope is confined to Member States' public authorities, corporations, etc. If the need for a Directive of this kind is recognised, there is an equally strong need for Community bodies and authorities to provide access to information. The Committee sees no reason for putting off this legislation until a later date. ${ }^{16}$

\footnotetext{
${ }^{14}$ This Committee boasts that it gives the EC institutions the views of the people "on the ground" those most directly affected by EC legislation. This non-political organisation consists of representatives of employers' organisations, trade unions, farmers, consumer groups, and professional associations in Europe. Answers to frequently asked questions concerning this Committee: http://www.esc.eu.int/pages/en/faq/faq.htm. For more information about this Committee, see The European Economic and Social Committee, The EESC in Ten Points (Brussels, European Economic and Social Committee, 2005). This booklet is also available on the web site of this Committee, http://www.esc.eu.int/publications/pdf/leaflets/EESC-2002-016-EN.pdf

15 Opinion on the proposal for a Council Directive on the freedom of access to information on the environment [1989] OJ C139/47.

${ }^{16}$ Ibid.
} 
The Committee stressed that "the obligation to disclose information should also cover the European Community authorities" when commenting on Article 2(c) paragraph 2 of the proposal, which defined the term "public authorities" as "[s]tate administrations and any public body or State-supervised body with powers at national, regional or local level". The Committee also criticised the attempt shown in Article 2(c) paragraph 2 to exclude legislative bodies from such obligation. It said that "[i]t also does not seem logical to the Committee to exclude legislative bodies from this obligation. The private citizen and other interested parties could have a legitimate interest in the opinions, etc., of these bodies".

The Council in June 1990 adopted the Directive without extending the scope of the draft to the Community authorities. ${ }^{17}$ This legislation came into force on 1 January 1993. According to Article 1 of this Directive, "[t]he object of this Directive is to ensure freedom of access to, and dissemination of, information on the environment held by public authorities and to set out the basic terms and conditions on which such information should be made available". The Council avoided claiming that dissemination of the environmental information held by the public authorities would be ensured throughout the Community. Article 2(b) states that "“public authorities' shall mean any public administration at national, regional or local level with responsibilities, and possessing information, relating to the environment with the exception of bodies acting in a judicial or legislative capacity". This provision indicated that this Directive was still intended to apply to the Member States rather than the Communities authorities.

In January 2003, the Parliament and the Council adopted a new Directive on

\footnotetext{
${ }^{17}$ Council Directive of 7 June 1990 on the freedom of access to information on the environment (90/313/EEC) [1990] OJ L158/56. This Directive is no longer in force.
} 
access to environmental information. ${ }^{18}$ This Directive sets out measures in addition to those in the 1990 Directive in order to expand the access to environmental information in the EU. Nevertheless, the scope of the 2003 Directive is still confined to the public authorities at national, regional or local level rather than those at Community level. ${ }^{19}$

\subsection{The Zwartveld case ch $^{20}$}

The Directive on environmental information noted above revealed that the Commission was generous in making Member State information available to the public but declined to extend similar rules to its information. What was the attitude of the Commission? Was it opposed to openness or just cautious in moving forward at this time as it was preparing to offer more freedom of information to people in the Community? The Zwartveld judgment is very important because it was the first time that the Commission revealed its attitude as to whether its documents should be accessible to the public.

\subsubsection{Facts}

The Rechter-commissaris (investigating magistrate) at the Arrondissementsrechtbank

\footnotetext{
${ }^{18}$ Directive 2003/4/EC of the European Parliament and of the Council of 28 January 2003 on public access to environmental information and repealing Council Directive 90/313/EEC [2003] OJ L41/26.

${ }_{19}$ Articles 1(a) and 2(2) of this Directive, n. 18 above.

${ }^{20}$ Case C-2/88 Imm, Zwartveld and others [1990] ECR I-3365.
} 
(District Court) Groningen, the Netherlands, submitted to the European Court of Justice a "request for judicial cooperation", saying the members of the management of a Dutch fish market were under investigation for having allegedly committed a crime of fraud when introducing a black market, in addition to the official market. This was in breach of the Dutch law adopted to implement the Community rules on fishing quotas. ${ }^{21}$ The Rechter-commissaris told the ECJ that European Economic Community (EEC) inspectors conducted inspections in the Netherlands between 1983 and $1986 .^{22}$ He requested the Commission to offer the inspection reports, and if necessary, to allow him to take evidence from the inspectors. ${ }^{23}$ This request was refused as "the documents formed part of a file on legal matters pending in the Commission". ${ }^{24}$ He referred to Articles 1 and 12 of the Protocol on the Privileges and Immunities of the European Communities, ${ }^{25}$ requesting the ECJ to order the Commission to offer the documents that he had failed to obtain. He also asked the ECJ to order or at least allow the inspectors and senior officials in the Directorate-General for Fisheries to be examined as witnesses by him or in his presence by a Community examining magistrate. ${ }^{26}$

The Commission contended before the ECJ that the Rechter-commissaris's request was inadmissible. ${ }^{27}$ The Commission said that " $[\mathrm{t}]$ he right of national courts to refer a case to the Court was regulated exhaustively in Article 177 of the EEC

${ }^{21}$ para. 1(i) and para. 1(ii), n. 20 above.

22 para. 1(iii), n. 20 above.

${ }^{23}$ para. 1(iv), n. 20 above.

24 para. 1(v), n. 20 above.

${ }^{25}$ This protocol was annexed to the Treaty establishing a Single Council and Single Commission of the European Communities of 8 April 1965. Article 1 of the Protocol provides that " $[t]$ he premises and buildings of the Communities shall be inviolable. They shall be exempt from search, requisition, confiscation or expropriation. The property and assets of the Communities shall not be the subject of any administrative or legal measure of constraint without the authorisation of the Court of Justice". Article 12 of the Protocol details types of the privileges and immunities granted to officials of the European Communities.

${ }^{26}$ para. 2 , n. 20 above.

${ }^{27}$ para. 3, n. 20 above. 
Treaty". ${ }^{28}$ Under former Article 177(a) EEC (now Article 234 EC), the Court has jurisdiction to give preliminary rulings concerning the interpretation of this Treaty. The Commission said the request at issue "did not concern the interpretation of a provision of the EEC Treaty or secondary legislation". ${ }^{29}$ It also stated the legal basis on which it opposed disclosure, saying there was no obligation to do so under Articles 1 and 2 of the Protocol. ${ }^{30}$ It added that "[A]rticle 12 did not concern the hearing of officials and other servants of the Community as witnesses or the lifting in that connection of the immunities enjoyed by those persons". ${ }^{31}$ The Commission eventually revealed its views on the report sought in the following statement:

[T]he report drawn up by [the] inspectors were documents which of their nature could not be used except for internal information. They were purely internal documents and could not commit the Commission or reflect its position. Their production might in addition jeopardise the Commission's relations with the Member States in the delicate area of supervision. ${ }^{32}$

The Commission said it was not prepared to divulge the identity of the inspectors or to authorise them to give evidence. "Any obligation on inspectors to be examined as witnesses would appreciably affect their work and therefore the effectiveness of

\footnotetext{
${ }^{28}$ Former Article 177 EEC provides that:

The Court of Justice shall have jurisdiction to give preliminary rulings concerning:

(a) the interpretation of this Treaty;

(b) the validity and interpretation of acts of the institutions of the Community;

(c) the interpretation of the statutes of bodies established by an act of the Council, where those statutes so provide.

Where such a question is raised before any court or tribunal of a Member State, that court or tribunal may, if it considers that a decision on the question is necessary to enable it to give judgment, request the Court of Justice to give a ruling thereon.

Where any such question is raised in a case pending before a court or tribunal of a Member State, against whose decisions there is no judicial remedy under national law, that court or tribunal shall bring the matter before the Court of Justice.

${ }^{29}$ para. 4 , n. 20 above.

${ }^{30}$ Article 2 of the Protocol states that " $[t]$ he archives of the Communities shall be inviolable".

${ }^{31}$ para. 5 , n. 20 above.

32 para. 7 , n. 20 above.
} 
Community supervision", 33

\subsubsection{Held}

The ECJ stated that relations between the Member States and the Community institutions were governed, according to former Article 5 EEC (now Article 10 EC), ${ }^{34}$ by a principle of sincere cooperation. ${ }^{35}$ It said the Protocol, designed to avoid interference with the functioning of the Communities, did not permit the institutions to neglect the duty of sincere cooperation with the national authorities, adding that such duty is referred to in Article 19 of the Protocol itself. ${ }^{36}$ The ECJ stated that "[i]t is incumbent upon every Community institution to give its active assistance to such national legal proceedings, by producing documents to the national court and authorising its officials to give evidence in the national proceedings". 37

Addressing the Commission's challenge to its jurisdiction, the Court stated that "[t]he Court, which is responsible under Article 164 of the EEC Treaty ${ }^{38}$ for ensuring that in the interpretation and application of the Treaty the law is observed, must have the power to review ... whether the duty of sincere cooperation,

${ }_{33}$ para. 10, n. 20 above.

${ }^{34}$ Former Article 5 EEC provides that:

Member States shall take all appropriate measures, whether general or particular, to ensure fulfillment of the obligations arising out of this Treaty or resulting from action taken by the institutions of the Community. They shall facilitate the achievement of the Community's tasks.

They shall abstain from any measure which could jeopardise the attainment of the objectives of this Treaty.

${ }_{35}^{35}$ para. 17, n. 20 above.

${ }^{36}$ paras. 19 and 21, n. 20 above. Article 19 of the Protocol states that "[t]he institutions of the Communities shall, for the purpose of applying this Protocol, cooperate with the responsible authorities of the Member States concerned".

${ }_{37}^{37}$ para. 22 , n. 20 above.

${ }^{38}$ Former Article 164 EEC provides that " $[t]$ he Court of Justice shall ensure that in the interpretation and application of this Treaty the law is observed". 
incumbent on the Commission in this case, has been complied with". ${ }^{39}$ Consequently, the Court held that the Commission had to produce to the Rechter-commissaris the requested documents and to authorise its officials to be witnesses before the district court, unless the Commission could present imperative reasons concerning the need to safeguard the functioning of the communities and could justify its refusal. ${ }^{40}$

\subsubsection{Comment}

The disputes in the present case appeared to relate to the scope of sincere cooperation and privileges of the Community institutions, but the nature of the controversy concerned conflicts between secrecy and freedom of information, rather than the definition of cooperation and privileges. Where the Commission agreed to assist the Rechter-commissaris in the investigation by offering the documents to him, it was unnecessary for him to take evidence from the inspectors concerned. The disputes were, in fact, triggered by the Commission refusal. There was a strong need for more freedom of information because the Member States and the institutions would not be able to cooperate sincerely with each other without sharing information. It was, therefore, the FOI legislation rather than definition of the terms "sincere cooperation" and "privileges" that could help end this controversy.

The Commission adopted three major strategies to avoid disclosing the information sought or allow the EEC inspectors to be witnesses. First, it took advantage of the privileges granted by the Protocol, which was intended to avoid

\footnotetext{
39 para. 23 , n. 20 above.

40 paras. 25 and 26, n. 20 above.
} 
interference with the functioning and independence of the Communities. As there were no definitions of the terms "archives" and "inviolable" in Article 2 or the other provisions of the Protocol, the Commission defined them in the broadest sense. Offering of investigation reports to the Rechter-commissaris was regarded by the Commission to be a violation of archives, even though the information related to potential infringements of Community law. Describing the reports sought as "purely internal documents", the Commission said production of them "might in addition jeopardise the Commission's relations with the Member States in the delicate area of supervision". However, the Rechter-commissaris was seeking to ensure that Community law was respected and it is thus arguable that he should be allowed to make use of the reports, even though these relations could be slightly damaged.

The second strategy adopted by the Commission was to read the term "work" in a narrow fashion, arguing that the work of the EEC inspectors would be appreciably affected if they served as witnesses. However, cooperation with judicial authorities of a Member State to guarantee the application and effectiveness of Community law was also part of the officials' work. This cooperation should not to be regarded as having a negative impact on the effectiveness of Community supervision. Third, the Commission made a literal interpretation of Article 2 of the Protocol when stressing that this provision did not empower the ECJ to lift the inviolability of the law. It made a further attempt to exclude the Court from addressing this dispute in its interpretation of Article $177 \mathrm{EEC}$, before it stated that both Articles 1 and 2 of the Protocol did not relate to this case, suggesting that the Rechter-commissaris had misinterpreted these two provisions.

It was almost impossible for the ECJ to admit that it had no jurisdiction in this case, because if it did so, the institution would be able to avoid cooperation with the 
Member States by extending the scope of "purely internal information". The ECJ stressed it "must have the power" to review this case under Article 164 EEC. However, it did not respond to the basis of the challenge by the Commission, which stated that the district court was not entitled to refer this case to the ECJ under Article 177 EEC.

The ECJ provided the Rechter-commissaris with the right to the requested information by interpreting the term "sincere cooperation" very broadly, but this measure helped solve only part of the real problem. The citizens in the Community would presumably be supportive of the ECJ's efforts to extend the scope of the right to information. ${ }^{41}$ It is, however, contentious whether the Court should have made such a broad interpretation of sincere cooperation, an uncertain legal concept in EC law. We also doubt whether the ECJ would apply the principle again if a court in a Member State were to request access to documents held by the Parliament or Court.

This dispute indicated that the Community was in need of FOI legislation. In the present case, the Commission tried stopping the Rechter-commissaris from obtaining the information by extending the scope of its legal privileges. This case also indicated that the jurisdiction of the ECJ concerning the right to information should be explicitly defined in legislation, or its jurisdiction could be challenged by a party trying to avoid judicial scrutiny. In addition, the citizens in the Community were in need of not only the documents possessed by the Commission but also those held by the other institutions.

The first stage of the development of EU policy in the field of freedom of

\footnotetext{
${ }^{41}$ This innovative judgment was widely hailed at the time as the first step towards creating greater openness in the administration of the Community in general. Curtin and Meijers, n. 3 above, at 82 and 83. It should, however, be noted that although the Court extended the scope of FOI protection to the Member States, it did not extend it to citizens in the Community in this judgment.
} 
information highlights the attitude of the decision-makers in the 1980s and lays the ground-work for analysis of the second stage of the evolution. It can be concluded that the Parliament made an effort to create a framework for FOI legislation from the beginning of this stage, but the Council and Commission took little action in response and even tried to obstruct Member States from accessing its documentation.

\subsection{Ratification crisis}

The Netherlands was the first Member State to show serious interest in freedom of information in the Community. It was the only nation to indicate awareness in January 1991 at the Maastricht Intergovernmental Conference (IGC) that there could be a future transparency problem. The Dutch delegation proposed to amend Article 213 EEC (now Article 284 EC). ${ }^{42}$ The idea was to establish explicit competence for the Council to adopt a regulation on access to information held by the Community institutions and organs. ${ }^{43}$ These efforts indicate that the Dutch delegation was of the opinion that the issue of freedom of information was not so much a matter of the internal working procedures of the institutions, but rather that of the public's right to information. ${ }^{44}$ There was, however, only a consolation prize for the Netherlands:

\footnotetext{
${ }^{42}$ Former Article 213 EEC states that "[t]he Commission may, within the limits and under the conditions laid down by the Council in accordance with the provisions of this Treaty, collect any information and carry out any checks required for the performance of the tasks entrusted to it".

${ }^{43}$ According to the plan by the Dutch delegation, some of the institutions and organs, including the Court of Justice, the Court of Auditors, the European Investment Bank and the European Central Bank, were excluded for imperative reasons tied to their independence from political interference. D. Curtin and H. Meijers, n. 3 above, at 83 , and references there cited.

${ }^{44}$ Ibid.
} 
Declaration 17 to the Maastricht Treaty (Treaty on European Union). The Maastricht IGC stated in a non-legally binding Declaration that:

The Conference considers that transparency of the decision-making process strengthens the democratic nature of the institutions and the public's confidence in the administration. The Conference accordingly recommends that the Commission submit to the Council no later than 1993 a report on measures designed to improve public access to the information available to the institutions.

Those attending the IGC, with the exception of the Dutch delegates, did not grasp the chance to enhance public accountability directly themselves by amending the Treaty of Rome. They recommended the Commission, an institution which, as we have seen, had not contributed much to FOI protection, to design the measures to increase access to the information held by itself and the other the Community institutions.

On 2 June 1992, of the 82.9 percent Danish voters who voted, 49.3 voted to approve the Maastricht Treaty but 50.7 percent were against it in a referendum. ${ }^{45}$ The Commission, the Danish government, and other Member States that spent a year negotiating the Maastricht Treaty, never considered that a majority of Danes, or of any other nationality, would vote against this Treaty. ${ }^{46}$ They were extraordinarily complacent owing to Denmark's positive results of the 1972 accession referendum ${ }^{47}$ and the 1986 Single European Act (SEA) referendum. ${ }^{48}$ The "yes" votes suggested

\footnotetext{
${ }^{45}$ Like the SEA, the Maastricht Treaty had to be ratified by each Member State before it could come into force. Ratification procedures differed from country to country in the Community. In Denmark, it was up to the electorate to decide in a referendum. Dinan, n. 4 above, at 149.

${ }^{46}$ Dinan, n. 4 above, at 149.

47 The referendum in Denmark resulted in an impressive endorsement of membership in early October, 1972, one week after a narrow majority voted against accession in a non-binding vote. 63 percent voted in favour of accession. It was necessary for Denmark to enter the enlarged Community at that time, with the bulk of the country's exports going to the United Kingdom and Germany.

${ }^{48}$ A majority of Danes in 1986 endorsed the SEA following the Danish parliament's rejection of it.
} 
that a majority of Danes would presumably support major treaty reform again. The Danish electorate's narrow rejection of the Treaty thwarted implementation of it and jeopardised the future of European integration. The impact of this vote was all the more striking as ratification was proceeding smoothly in every other Member State.

The Irish referendum followed on 18 June 1992, two weeks after the Danish "no" vote. Of the 57 percent who voted, 69 percent favoured the ratification and 31 percent against. The French electorate went to the polls on 20 September 1992, which assumed much more significance for the Treaty as France had historically been a pivotal member of the Community. A positive result would help dispel the gloom caused by the Danish "no" vote, but a negative one would shake the Community to its core. The result revealed that, in a 70 percent turnout, only a narrow majority of 51.05 percent voted in favour of the ratification and 48.95 percent voted against it.

After the negative result in Denmark, exhaustive analyses indicated a host of reasons for the no votes, including, inter alia, concerns about European Monetary Union, about losing national identity, and about the role of small states in the Community. ${ }^{49}$ In addition, Professor Desmond Dinan says that "[a]t issue in Denmark and elsewhere was the so-called democratic deficit: the EU's perceived remoteness and lack of accountability". ${ }^{50}$ A writer also said the Maastricht Treaty's

\footnotetext{
${ }^{49}$ Dinan, n. 4 above, at 149. The Danish government embodied the Danes' concerns in a White Paper published in October 1992. The Danish government said in this document that it wanted the other Member States to accept clauses that would, inter alia, permit Denmark to opt out of currency union, any future common defence policy, any institutionalisation of European citizenship. D. Urwin, Community of Europe: A History of European Integration Since 1945 ( $2^{\text {nd }}$ edn., London, Longman, 1995), 258. These conditions were accepted in full by participants in the European Council in Edinburgh in December 1992. See 'Decision of the Heads of State and Government, Meeting within the European Council, concerning Certain Problems Raised by Denmark on the Treaty on European Union,' European Council, Edinburgh Summit, 11-12 December 1992, available at http://www.europarl.eu.int/summits/edinburgh/b1_en.pdf

50 Professor Dinan says the issue concerning the democratic deficit remains a major challenge for the Union into the twenty-first century. D. Dinan, 'How Did We Get Here?' in Bomberg and Stubb (eds.),
} 
defeat in Denmark and the narrow approval in France had pointed out the large gap that existed between European citizens and those who governed them, especially the Eurocrats in Brussels. ${ }^{51}$ In addition, Mr. Peter Dyrberg says that the Danish and French referenda, as well as opinion polls in other countries that demonstrated scant popular support for the Union, "made it urgent to act upon this Declaration, and transparency found its way onto the agenda of European Council meetings". 52 To be brief, a lack of transparency in the Community was one of the major reasons for the "no" votes in Denmark. The ratification crisis also revealed that Declaration 17, a compromise solution and the "sop" to the Dutch demands for a more open administration, was insufficient to satisfy the information requirements of European citizens, if no action was taken accordingly in response of demands for more FOI protection.

\subsection{Response of the Heads of State or Government at the European Council summits in Birmingham and Edinburgh}

Leaders of the Community and high-ranking officials of the Member States grasped the seriousness of the Danish referendum result. Among these leaders was Mr. Jacques Delors, European Commission President from 1985 to 1995, who resolved to emphasise subsidiarity to ensure the Union's compatibility with the political

\footnotetext{
n. 8 above, at 35 .

${ }_{51}^{51}$ Paraschos, n. 1 above, at 115.

52 P. Dyrberg, 'Accountability and Legitimacy: What is the Contribution of Transparency?' in A. Arnull and D. Wincott (cds.), Accountability and Legitimacy in the European Union (Oxford, Oxford University Press, 2002), 87.
} 
aspirations of its citizens, ${ }^{53}$ and to make the legislative process more transparent.

\subsubsection{The Birmingham summit}

In response to the significance of the Danish and French votes, the Heads of State or

Government of the Member States participating in the Birmingham summit in October 1992 stated in the first part of the "Birmingham Declaration" entitled "A Community close to its citizens" that "[a]s a community of democracies, we can only move forward with the support of our citizens". ${ }^{4}$ This statement indicated that they had realised that the future of the Community could be jeopardised if they kept ignoring the Community's perceived lack of democracy. To make the legislative process more transparent, the leaders of the Member States welcomed the Commission's offer to consult more widely before proposing legislation, which could include a more systematic use of consultation documents (green papers), stating that "[w]e want Community legislation to become simpler and clearer". ${ }^{55}$

Acting in response to the concerns raised in the debates prior to this summit, the

\footnotetext{
${ }^{53} \mathrm{Mr}$. Delors began to explore subsidiarity from the time that he became Commission President in 1985 , in order to search for a doctrine that would allow the Union to become involved in certain "high political" issucs traditionally at the core of national sovereignty without encroaching on policy areas that should remain in the national or regional domain. Dinan, n. 4 above, at 152, and sources there cited. Former Article $3 \mathrm{~b}$ EC (now Article $5 \mathrm{EC}$ ) provides that:

The Community shall act within the limits of the powers conferred upon it by this Treaty and of the objectives assigned to it therein.

In areas which do not fall within its exclusive competence, the Community shall take action, in accordance with the principle of subsidiarity, only if and insofar as the objectives of the proposed action cannot be sufficiently achieved by the Member States and can therefore, by reason of the scale or effects of the proposed action, be better achieved by the Community.

Any action by the Community shall not go beyond what is necessary to achieve the objectives of this Treaty.

${ }^{54}$ See particular the Declaration by the Heads of State or Government European Council, Birmingham, 16 Oct. 1992, http://www.europarl.eu.int/summits/birmingham/bi_en.pdf

${ }^{55}$ Ibid.
} 
Birmingham European Council stated that it must, inter alia, "make the Community more open, to ensure a better informed public debate on its activities". To realise this ideal, the participants continue to say that:

Foreign ministers will suggest ways, before the Edinburgh European Council, of opening up the work of the Community's institutions, including the possibility of some open Council discussion - for example on future work programmes. ... We ask the Commission to complete by early [1993] its work on improving public access to the information available to it and to other Community institutions. ${ }^{56}$

The European Council's legal status should be considered when assessing its contribution to greater EC transparency at Birmingham. The European Council operated to an extent outside the main institutional structure of the Community until the late 1980s, though Article 2 SEA in 1986 gave it legal recognition. ${ }^{57}$ The Maastricht IGC introduced Article D TEU (now Article 4 TEU) that built on Article 2 SEA; Article D TEU provided that " $[\mathrm{t}] \mathrm{he}$ European Council shall provide the Union with the necessary impetus for its development and shall define the general political guidelines thereof" ${ }^{58}$ In other words, the European Council was expected by the

${ }^{56}$ n. 54 above.

57 Two important summits of the European Council, in The Hague in 1969 and Paris in 1972, were agenda-setters for succeeding years. Article 2 SEA gave legal recognition to the European Council, stating that:

The European Council shall bring together the Heads of State or of Government of the Member States and the President of the Commission of the European Communities. They shall be assisted by the Ministers for Foreign Affairs and by a Member of the Commission.

The European Council shall meet at least twice a year.

This provision, which was later repealed after successive treaty amendments, put the European Council on to a more official basis. H. Wallace, 'The Institutional Setting' in H. Wallace and W. Wallace (eds.), Policy-making in the European Union ( $4^{\text {th }}$ edn., Oxford, Oxford University Press, 2000), 20.

${ }^{58}$ In practice, when the European Council addresses Community matters, it usually takes general political decisions; these are then translated into legal form at meetings of the Council held at ministerial level. Hartley, n. 11 above, at 26. 
Maastricht IGC to address strategic questions. ${ }^{59}$ Participants at the Birmingham summit did not lay down any guideline on FOI legislation, though they would have realised the importance of FOI protection owing to the "no" vote in Denmark. The only effort made by the political leaders was, however, to demand once again that the Commission should improve access to information. They did not address one of the main reasons for the negative result in Denmark -- the excessive secrecy in the Council, a major cause of the democratic deficit.

As regards the Council, it consists of the delegates of the Member States, and each State is represented by a government minister authorised to commit his or her government. ${ }^{60}$ It has long been the institution where the interests of the Member States find direct expression. Under the co-decision procedure introduced by Maastricht Treaty, the Council, working with the Parliament, ${ }^{61}$ takes the final decision on most EC legislation and concludes agreements with foreign countries. The Council, jointly with the Parliament, also makes decisions on the Community budget. Deliberations of this important EC institution were, however, rarely available for the public prior to the upheaval caused by the EU Treaty ratification crisis. A writer said in 1991 that "[political] behavior inside the Council of Ministers is the least well studied or understood part of the activities of the European Community". ${ }^{62}$

\footnotetext{
59 The role of the European Council changed from the late 1980s and during the 1990s. It has increasingly become a venue for dealing with history-making decisions in the Union, i.e. the big and more strategic questions about core new tasks of the Union and those that define its 'identity' as an arena for collective action. Wallace, n. 57 above, at 20.

${ }^{60}$ Article 203 EC (ex Article 146 EC), Article 27 ECSC, and Article 116 Euratom.

${ }^{61}$ The Council and Parliament share legal responsibility for legislation under the co-decision procedure. The second paragraph of former Article 189b EC (now Article $251 \mathrm{EC}$ ) states that:

The Council, acting by a qualified majority after obtaining the opinion of the European Parliament, shall adopt a common position. The Common position shall be communicated to the European Parliament. The Council shall inform the European Parliament fully of the reasons which led it to adopt its common position. The Commission shall inform the European Parliament fully of its position.

${ }^{62} \mathrm{H}$. Wallace, 'The Council and the Commission after the Single European Act' in L. Hurwitz and C. Lequesne (eds.), The State of the European Community: Policies, Institutions, and Debates in the
} 
The participants in the Birmingham European Council only committed that "[f]oreign ministers will suggest ways of opening up the work of the Community's institutions, including the possibility of some open Council discussion - for example on future work programmes". This promise of uncertain and partial openness was obviously insufficient to improve the democratic order of the Council.

\subsubsection{The Edinburgh summit}

The Heads of State or of Government of the Member States participating in the subsequent Edinburgh European Council summit in December 1992 said they adopted specific measures to support transparency, adding they welcomed the Commission's decision to produce annual work programmes every October to allow for wider debate, including in the national parliaments. ${ }^{63}$ They also reconfirmed their invitation at Birmingham for the Commission to complete, by early 1993, its work "resulting from the declaration in the Maastricht Treaty on improving access to the information available to it and to other Community institutions".

An annex to the Edinburgh European Council's conclusions of the Presidency entitled "Transparency - Implementation of the Birmingham Declaration" revealed that the participants tried to strengthen public confidence by offering them more information about the Council. For instance, "[w]hen a formal vote is taken in

Transition Years (Boulder, Lynne Rienner, 1991), 20.

${ }^{63}$ The Commission made the decision about transparency to translate the decisions made by the Birmingham European Council into a formal form. This decision also included seeking closer consultation with the Council on the annual legislative programme; wider consultation before making proposals; use of green papers; making Commission documents public in all Community languages; and attaching higher priority to consolidation and codification of legal texts. "Conclusions of the Presidency - Edinburgh", http://www.europarl.eu.int/summits/edinburgh/a0_en.pdf 
Council, the record of the vote (including explanations of votes where delegations request these) shall be published". The participants said there would be open debates on relevant Presidency, Commission work programmes, and on major issues, adding that public access would be achieved by televising the debate for viewing in the press area of the Council building. Meanwhile, an effort was made to simplify the way to access Community legislation. However, some exceptions to these rules indicated that what the participants had achieved in the subject of transparency was limited. For example, they claimed there would be open debates on major issues of Community interest, but they said only the Council would have the right to decide whether it would approve a debate proposal, adding that such decision would be made on a case by case basis and on unanimity. Another example was that, although the participants said that "[m]ajor new legislative proposals will, whenever appropriate, be the subject of a preliminary open debate, in the relevant Council, on the basis of the Commission's legislative proposal", they also said the Council was entitled to decide whether it would approve a debate proposal on a case by case basis and on unanimity.

As to FOI protection, the political leaders of the Member States stated that transparency as to decisions of the Council would be extended to all Council positions through the practice of publishing a full description in the press release of the conclusions reached by the Council. They showed a generous spirit in this statement but immediately set out exceptions to the measure: "exceptions being made for cases where such information would damage the interests of the Member States, the Council, or the Community - e.g. negotiating mandates". The lack of definition of the term "interests" reduced the value of this measure, indicating that the Edinburgh European Council did not promise the public significantly more FOI 
protection.

Other specific measures noted by the participants in the Edinburgh summit revealed that they sought to make European citizens believe that the EC institutions were closer to them than they had been previously. This conference emphasised the need for better informed public debate on the Community's activities and measures to support this, as the Heads of State or of Government of the Member States appeared to have noticed the growing public resentment towards the Community. Unfortunately, they failed to realise that the best way to close the Community's democratic deficit was to help enact FOI legislation. They did not recognise freedom of information as a fundamental right, because they did not make a call for change in the EU Treaty to include explicit competence for the Council to adopt a regulation on access to information held by the Community institutions. In fact, they made no attempt at all to help the Community have its own FOI legislation.

\subsubsection{Conclusion}

The European Council is not a Community institution, but it has been expected to meet to resolve intractable problems and lead the Union at the highest political level. It is, however, surprising that the participants in the two summits achieved less than the European Parliament in 1994. The Parliament showed serious interest in this subject and adopted a resolution eight years before the Edinburgh summit. ${ }^{64}$ The Parliament, according to the Resolution, considered that "the European Community should have its own legislation on openness of government of Community affairs".

\footnotetext{
${ }^{64}$ n. 2 above.
} 
The political leaders at the Birmingham and Edinburgh summits made four major efforts to realise transparency within the Community.

(1) They stated that some Council debates might be available to the public.

(2) They demanded the production by the Commission of the annual work programme every October.

(3) They decided to simplify and clarify Community legislation.

(4) They repeatedly demanded that the Commission design and implement the rules on freedom of information in 1993.

Generally, freedom of information means having access to government documents or information in other forms, to understand the government's policies. Transparency has a wider reach than freedom of information as it is also linked to a variety of demands such as those for more open debates on key public issues and more easily readable instruments. The specific measures adopted at these summits achieved something in making the legislative process more transparent but achieved little in providing the public with more FOI protection. It should be stressed that information on the ongoing legislative process is only part of the information beneficial to the public. In this regard, the three summits took only limited steps to realise transparency and it was clear that FOI protection would not be realised without a regulation on this subject. 


\subsection{The Commission report}

In Declaration 17 to the Maastricht Treaty, the Maastricht IGC recommended that "the Commission submit to the Council no later than 1993 a report on measures designed to improve public access to the information available to the institutions". Participants in the Birmingham and Edinburgh summits also demanded that the Commission complete such a report in 1993. The pressure for stronger assurance on a right of access came not only from these demands and the setbacks in Demark and France, but also from negotiations for accession to the Union with Sweden and Finland. The two Nordic nations had strong traditions of governmental openness. ${ }^{65}$ On 5 May 1993, the Commission submitted to the Council the long-awaited report, entitled "Public Access to the Institutions' Documents", 66 following a comparative survey of existing FOI policies in the Member States and those in some third countries, such as the United States and Australia. The Commission stated in the report that:

The Commission views [Declaration 17] as an important element of the Community's policy on transparency of the institutions. Improved access to information will be a means of bringing the public closer to the Community institutions and of stimulating a more informed and involved debate on Community policy matters. It will also be a means of increasing the public's confidence in the Community.

\footnotetext{
${ }^{65}$ C. Hoskyns, 'Democratizing the EU: Evidence and Argument' in C. Hoskyns and M Newman (eds.), Democratizing the European Union, Issues for the Twenty-First Century (Manchester, Manchester University Press, 2000), 180. In addition, Nils Herlitz, a professor emeritus of constitutional and administrative law at the University of Stockholm, said in 1958 that many in other countries had expressed surprise over the Swedish access to documents legislation when a Swede said that "the records of public authorities are open to anybody who wants to see a document." N. Herlitz, 'Publicity of official documents in Sweden' (1958) Public Law 50.

${ }^{66}$ Public Access to the Institutions' documents (Communication to the Council, the Parliament and the Economic and Social Committee) [1993] OJ C156/5.
} 
The Commission said it considered Declaration 17 a key element of transparency policy and that the survey was conducted to implement this Declaration. The Commission stated in this report that it would establish a framework for granting general access to documents. "This will entail some adjustments of the Commission's working practices but the Commission considers that general arcess is a particularly important instrument to bring the Community closer to its citizens" ${ }^{67}$ Nonetheless, the Commission only carried out part of the duties the Maastricht IGC imposed on it. The IGC in the Declaration recommended that the Commission submit "a report on measures to improve the public access to the information available to the institutions", but the Commission report indicated that the Commission did not work out any concrete measures to increase access to information held by the other EU institutions. The Commission only said it "felt" that the principle of access to information should be shared by the other institutions and Member States.

The Commission stated in this report that "[t]he public is granted access to specific types of information in some countries, ... Directive 90/313/EEC on access to environmental information is an example of a Community initiative on access to a specific area of information". This statement indicated that the Commission had endeavoured to realise freedom of information previously, but the Directive, as we have seen, was intended to apply only to relevant "public administration at national, regional or local level", rather than the Community institutions. ${ }^{68}$

In June 1993, participants in the European Council in Copenhagen asked the

\footnotetext{
${ }^{67}$ Ibid.

${ }^{68}$ Article 2(b) of the Directive provides that "'public authorities' shall mean any public administration at national, regional or local level with responsibilitics, and possessing information, relating to the environment with the exception of bodies acting in a judicial or legislative capacity". n. 17 above.
} 
Council and Commission to continue to improve FOI protection, stating that "[i]n the area of public access to information, [the European Council] invited the Council and the Commission to continue their work based on the principle of the citizens having the fullest possible access to information. The aim should be to have all necessary measures in place by the end of $1993 " .69$ The participants at this summit set up the timetable for implementation of the rules on access to information for the first time. The Copenhagen European Council, however, ignored that both the Council and the Commission had never conducted their work in the field of transparency on the principle of the "fullest possible access to information".

Five months later, the Danish voters approved the Maastricht Treaty in a second referendum in May 1993. Of the 71.4 percent who voted, 56.7 percent of them favoured an approval of this Treaty and 43.3 percent against, allowing the EU to come into being in November 1993. This should not be regarded as Danish citizens' firm support for the Union, as 43.3 percent of the voters were against the Treaty. Professor Desmond Dinan says that exhaustive analyses indicate a host of reasons for the result, but "[w]hatever the reasons, the result showed how oblivious the Danish and other governments were to growing public resentment toward the EC". ${ }^{70}$

\footnotetext{
69 The full text of "Conclusions of the Presidency - Copenhagen" is available at: http://www.europarl.eu.int/summits/copenhagen/co_en.pdf

70 Dinan, n. 4 above, at 149.
} 


\section{3}

\section{The Framework Established \\ by the Code of Conduct \\ - Evolution II (1993 2000)}

The Council and Commission in November 1993 adopted a common instrument the Code of Conduct concerning public access to Council and Commission documents. ${ }^{1}$ The Code of Conduct provides that the two institutions would severally take steps to implement its principles before 1 January 1994. The implementation took the form of decisions taken by the two institutions separately in December 1993 and February 1994 - Council Decision 93/731 and Commission Decision 94/90. ${ }^{2}$ This chapter analyses the Code of Conduct, the two corresponding decisions, and relevant court decisions relating to the mandatory and discretionary exemptions set out in the three measures. The aim of the examination is to obtain a clear picture of the exceptions' nature and to determine the Community court's views on the application of the two categories of exception.

\footnotetext{
1 (93/730/EC) [1993] OJ L340/41.

${ }^{2}$ Council Decision of 20 December 1993 on public access to Council documents (93/731/EC) [1993] OJ L340/43, and Commission Decision of 8 February 1994 on public access to Commission documents (94/90/ECSC, EC, Euratom) [1994] OJ L46/58.
} 


\title{
3.1 The Code of Conduct and corresponding
}

\author{
decisions
}

\subsubsection{Exclusion of other institutions}

The Code of Conduct, a common agreement between the Commission and Council, was the first EC provision to deal generally with access to information held by its institutions, but it was far from perfect. First of all, the Code of Conduct was deficient as it excluded many key institutions in the EU. Crucially, it only covered the Council and Commission. The EU institutions are dynamic organisms exercising a unique mix of legislative, executive, and judicial power. ${ }^{3}$ In addition to the five most important institutions - the Commission, the Council, the European Council, the Parliament, and the European Court of Justice, ${ }^{4}$ there are other institutions carrying out a variety of representative, oversight, or managerial functions in the Union. There was, however, no reference in the Code of Conduct and corresponding decisions to the European Council, to the other institutions, or to the Second and Third Pillars of the Union. Institutions and satellites emanating from these institutions were also excluded. The inability of the Council and Commission to impose such requirements on these other bodies is a direct result of deciding to proceed not through a recognised legislative measure but by means of an internal agreement.

\footnotetext{
${ }^{3}$ E. Bomberg, L. Cram, and D. Martin, 'The EU's Institutions' in E. Bomberg and A. Stubb (eds.), The European Union: How Does it Work?" (Oxford, Oxford University Press, 2003), 43.

${ }^{4}$ Ibid. Strictly speaking, the European Council is not an EU institution, but its role is of great importance as it is required to address strategic questions. The European Council, according to Article 4 TEU, "shall provide the Union with the necessary impetus for its development and shall define the general political guidelines thereof".
} 
For instance, prior to the adoption of the Code of Conduct, the plan to establish the European Central Bank (ECB) had been laid down in the Maastricht Treaty to better formulate the EU's monetary policy. ${ }^{5}$ The ECB, which was inaugurated on 1 June 1998, faced problems of openness after the Maastricht Treaty was signed in December $1991 .^{6}$ The issue of how, and to what extent, the European banking system should be made accountable then became controversial, ${ }^{7}$ but the Code of Conduct and two related decisions showed that the Council and Commission did not plan to make the ECB's documents available to the public. Analogous domestic specialised organisations are, however, typically included under national FOI law. ${ }^{8}$

In sum, the Council and Commission adopted the Code of Conduct to allow access only to the documents in their possession, though the European Ombudsman was capable of partially remedying this deficiency. This is because, when the Ombudsman investigates complaints, it has wide powers of access to documents held by Community institutions. ${ }^{9}$

\footnotetext{
${ }^{5}$ The ECB was made the most significant specialised institution by the participants in the Maastricht IGC. Former Article $107 \mathrm{EC}$ (now Article $108 \mathrm{EC}$ ) provided that the Community institutions and bodies and the government of the Member States shall not seek to influence the members of the decision-making bodies of the ECB or of the national central banks in the performance of their tasks.

${ }^{6}$ After the Maastricht Treaty was signed, the ECB has tried to maintain independence and to be viewed as accountable and legitimate to the European public at the same time.

${ }^{7}$ Some believe that no more than performance in maintaining price stability in the medium term should be used by the public to judge the success of the Eurosystem, but others think that decision-making by technocrats is acceptable and viable only if the institution to which these decisions are delegated is accountable to the public at large and to its elected representatives. C. Harlow, Accountability in the European Union (Oxford, Oxford University Press, 2002), 48-49.

${ }^{8}$ For instance, documents available to the Swedish public are those held, received or drawn up by any public authority, according to Article 3 of Chapter 2 of the 1949 Freedom of the Press Act, one of the four fundamental laws which made up the constitution of Swedish. The English translation of the Freedom of the Press Act is available at the Swedish government website: http://www.riksdagen.se/english/work/fundamental/press/index.htm

${ }^{9}$ For example, the first paragraph of Article 3(2) of the European Ombudsman Statute provides that "[t]he Community institutions and bodies shall be obliged to supply the Ombudsman with any information he has requested of them and give him access to the files concerned. They may refuse only on duly substantiated grounds of secrecy". [1994] OJ L113/15. The Ombudsman's role in EU FOI protection is examined in Chapter 7.
} 


\subsection{2 "Widest possible access"}

The Code of Conduct provided for more, but only limited, freedom of information. The general principle of the Code of Conduct is that: "The public will have the widest possible access to documents held by the Commission and the Council. 'Document' means any written text, whatever its medium, which contains existing data and is held by the Council or the Commission". ${ }^{10}$

Suppose a citizen of the Union asks a public body for a document that has never been released, there are two possible approaches to address the request:

(1) a presumption that the information ought to be offered to the citizen unless decision-makers within the Union have a good reason not to do so; or

(2) a presumption that the information should be kept secret unless the decision-makers decide to release it.

The Code of Conduct's appreciation concerning both the "widest possible access to documents" and "any written text" seemed to be a response to the call for "fullest possible access" made by the Copenhagen European Council. Such phrases suggested that the former approach had been adopted and that the Council and Commission, which had not made material efforts to realise the idea of access to information before the Code of Conduct, had altered their stance on the issue. However, the real position of the two major EU institutions at this time cannot be ascertained without examining the other parts of the legislation, in particular the provisions setting out exceptions to openness and those establishing the procedures for applying for documents.

\footnotetext{
${ }^{10}$ First section of the Code of Conduct entitled "general principle".
} 
Considering, first, the exceptions, these are set out in the Code of Conduct's fourth section entitled "exceptions":

The institutions will refuse access to any document whose disclosure could undermine:

-- the protection of the public interest (public security, international relations, monetary stability, court proceedings, inspections and investigations),

-- the protection of the individual and of privacy,

-- the protection of commercial and industrial secrecy,

-- the protection of the Community's financial interests,

-- the protection of confidentiality as requested by the natural or legal persons that supplied the information or as required by the legislation of the Member State that supplied the information.

They may also refuse access in order to protect the institution's interest in the confidentiality of its proceedings. (emphasis added)

This first subsection of this section covered almost all the usual areas contained in exemptions to openness in domestic legislation and couched them in mandatory terms; access will be denied where disclosure could undermine the abovementioned interests. Professor Carol Harlow has said that "[the] list of mandatory exceptions to disclosure [is] so extensive as to change the balance: from positive rights with negative exceptions to a text which treats access as the exception". ${ }^{11}$

The lists of specific exceptions were followed by a provision which provided the Council and Commission with a discretionary exemption where they wished to defend the confidentiality of their proceedings. The two institutions would have the right to impose an almost total ban on freedom of information to protect the abovementioned rights and interests. A Swedish writer has said that:

${ }^{11}$ Harlow, n. 7 above, at 38. 
[The Code of Conduct] includes precisely such a broad and imprecise category of exceptions which may be invoked as a last resort by Community institutions if none of the specifically enumerated exceptions are applicable. This of course allows for almost unlimited secrecy and thereby for the elimination of openness if Community institutions so wish. ${ }^{12}$

The very extensive exceptions revealed that the "widest possible access to documents" was severely limited in reality, owing to the five areas covered by exceptions and the two institutions' right to refuse access to information relating to their proceedings.

Limitations are also apparent in the procedures for applying for access to documents, set down in the Code of Conduct and the two corresponding Council and Commission decisions, ${ }^{13}$ and it is notable that the two institutions did not establish a register of their documents. This was a major impediment for those who wished to obtain access to a document. Another constraint was that the Council and Commission would provide the EU citizens with access only to the documents drawn up by the two institutions. The Code of Conduct provided that "[w]here the document held by an institution was written by a natural or legal person, a Member State, another Community institution or body or any other national or international body, the application must be sent direct to the author". As one writer observes, "[i]n essence, the Code left untouched the strict norm of confidentiality that has traditionally prevailed in international relations." ${ }^{14}$ Under this controversial provision, requests made to the Council or Commission for information received by

${ }^{12}$ I. Österdahl, 'Openness v. Secrecy: Public Access to Documents in Sweden and the European Union' (1998) 23 European Law Review 342.

${ }_{13}$ Procedures of applications for access to documents were laid down in the second section of the Code of Conduct, Article 2 of the Council decision, and Article 2 of the Commission decision. They required that an application must be made in writing in a sufficiently precise manner.

${ }^{14}$ A. Roberts, 'Multilateral Institutions and the Right to Information: Experience in the European Union' (2002) 8 European Public Law 260. 
the two institutions from another institution, or from a third party, would be refused. In other words, the EU institutions other than the Council and Commission, and third parties would have the right to decide whether they would provide applicants with access to the documents produced by them. As they would consider factors such as national interest, privacy and possibly personal interest, access to the documents written by them could also be highly problematic.

The Code of Conduct provided for a two-stage procedure which included not only the initial application but also "confirmatory applications". An applicant, according to the third section entitled "Processing of confirmatory applications," had the right to apply for a refusal to be reconsidered - a "confirmatory application" within one month. ${ }^{15}$ Under these rules, if the institution concerned decided to disapprove the access to information again, it had to inform the applicant of the second refusal immediately and the grounds on which the decision was based. Meanwhile, the decision had to indicate the means of redress that were available, i.e. judicial proceedings and complaints to the Ombudsman under the conditions specified in, respectively, Articles 173 and 138e EC (now Articles 230 and 195 EC).

The procedures relating to confirmatory applications could have been of great importance if the Code of Conduct had provided for wide access to information. As the legislation offered, however, only limited FOI protection to the public, the sound procedures of confirmatory applications were of little value in practice.

\footnotetext{
${ }^{15}$ The first paragraph of the Code of Conduct's third section states that "[w]here the relevant departments of the institution concerned intend to advise the institution to reject an application, they will inform the applicant thereof and tell him that he has one month to make a confirmatory application to the institution for that position to be reconsidered, failing which he will be deemed to have withdrawn his original application".
} 


\subsubsection{Comment}

The Code of Conduct, which established a general principle, and exceptions, as well as procedures for making applications and confirmatory applications, was only a fragmentary measure. ${ }^{16}$ It was insufficient to realise the ideal of access to information, and the principle of "widest possible access to documents" was only a hortatory statement. Widest possible access was impossible at that time because, first of all, the Code of Conduct did not appear on its face to be applicable to the Second and Third Pillars. Moreover, the European Council and EU institutions other than the Council and Commission were excluded. Secondly, the Council and Commission did not provide for a register of their documents under the Code of Conduct. Thirdly, the Council and Commission transferred their responsibility to defend the widest possible access to "a natural or legal person, a Member State, another Community institution or body or any other national or international body" where a document was produced by them.

The fourth, and presumably the most important reason, was that, in contrast to the Code of Conduct's principle of widest possible access, the measure laid down very wide exemptions. The Commission in a 1993 Report boasted that it was aware that it already had a "commendable history of an open door policy", adding that "[t]his stems from the belief that such a process is fundamental for the development of sound and workable policies". ${ }^{17}$ If the Commission and Council had not laid down the extensive mandatory and discretionary exceptions, they would have

\footnotetext{
${ }^{16}$ Professor Inger Österdahl has also said that "[t]he Code of Conduct taken as a whole hardly gives European Union citizens any right against the institutions except for some procedural aspects of minor importance concerning the reasons for rejections of applications for access to documents and the balancing of interests". Österdahl, n. 12 above, at 346-347.

${ }_{17}$ Public Access to the Institutions' Documents (Communication to the Council, the Parliament and the Economic and Social Committee) [1993] OJ C156/5.
} 
realised such a belief and put the development of freedom of information legislation on the right course. Nonetheless, the broad exceptions revealed that the two institutions at that time held the belief that secrecy ought to be the rule and openness the exception. Close review of the Code of Conduct indicates that the tone of openness couched in the legislation was not borne out by the seriously deficient text. In other words, the Commission did not follow through the demand made by the Copenhagen European Council, which stated that all necessary measures to realise the ideal of fullest possible access should be in place by the end of 1993 .

The following sections address the key judgments delivered by the ECJ and CFI between 1995 and 2001 in chronological order. The aim is to obtain a clear picture of the Courts' role in the development of EU FOI protection during this period. In the final section of this chapter, we pull together and analyse the key issues thrown up by these cases, such as the relevance of the distinction between the mandatory and discretionary exceptions, the applicability of the principle of proportionality, and whether individuals can gain access to Second and Third Pillar documents.

\subsection{The Carvel case ${ }^{18}$}

Exemptions to openness laid down in Article 4 of Council Decision 93/731 corresponded to those in the fourth section of the Code of Conduct. Article 4(1) of Council Decision 93/731, ${ }^{19}$ which included a list of specific exceptions, covered

\footnotetext{
${ }_{18}$ Case T-194/94, John Carvel and Guardian Newspapers v. Council [1995] ECR II-2769.

${ }^{19}$ Article 4(1) provides that:
} 
almost all the usual subjects contained in exceptions in domestic FOI legislation and couched them in mandatory terms. Article 4(2) of Decision 93/731 stated that "[a]ccess to a Council document may be refused in order to protect the confidentiality of the Council's proceedings". This provision, which provided the Council with a discretionary exemption where it wished to defend the confidentiality of its proceedings, was highly controversial. This provision might be invoked as a last resort by the Council, if none of the specifically enumerated exceptions in Article 4 (1) were applicable. Under Article 4(2), the Council was allowed to apply the provision as long as it considered a refusal of access to information was necessary to protect confidentiality of its proceedings. But what was the margin of this discretionary exception? The Court of First Instance (CFI) answered the question in John Carvel and Guardian Newspapers Ltd v. Council of the European Union. ${ }^{20}$

\subsubsection{Facts}

In February 1994, the applicants John Carvel, European Affairs Editor of The

Guardian, and Guardian Newspapers Ltd, sought access to the following documents held by the Council:

(1) the preparatory reports, the minutes, the attendance, voting records, and

Access to a Council document shall not be granted where its disclosure could undermine:

-- the protection of the public interest (public security, international relations, monetary stability, court proceedings, inspections and investigations),

-- the protection of the individual and of privacy,

-- the protection of commercial and industrial secrecy,

-- the protection of the Community's financial interests,

-- the protection of confidentiality as requested by the natural or legal person who supplied any of the information contained in the document or as required by the legislation of the Member State which supplied any of that information. (emphasis added)

20 n. 18 above. 
the decisions of the Councils of Ministers for Social Affairs (hereinafter "the Social Affairs Councils") of 12 October and 23 November 1993;

(2) the preparatory reports, the minutes, the attendance, voting records, and the decisions of the Council of Ministers for Justice (hereinafter "the Justice Council") of 29 and 30 November 1993;

(3) the minutes of the Council of Ministers for Agriculture (hereinafter "the Agriculture Council") of 24 and 25 January $1994 .^{21}$

On 28 February 1994, the applicants received from the General Secretariat of the Council a letter and a copy of the Social Affairs Councils' preparatory reports, the minutes, the attendance, and voting records in question. For the decisions on the dates, they were referred to the issues of the Official Journal of the European Communities in which those decisions appeared. ${ }^{22}$ The General Secretariat told the applicants in the letter that they were refused access to the Justice Council's minutes, the attendance, voting records and the decisions. ${ }^{23}$ The Council also refused access to the Justice Council's preparatory reports on the Justice Council's future work. ${ }^{24}$ In addition, the applicants were informed that the Agriculture Council's minutes in question "were not yet available." 25

The applicants then made a confirmatory application, reiterating their request for access to the documents relating to the Justice Council and to the Agriculture Council's minutes. ${ }^{26}$ However, the applicants received no response within the

${ }^{21}$ para. 14, n. 18 above.

22 para. 15, n. 18 above.

${ }^{23}$ para. 16, n. 18 above.

${ }_{24}$ para. 16, n. 18 above.

${ }_{25}$ para. 17, n. 18 above.

${ }^{26}$ para. 19, n. 18 above. 
time-limit of one month laid down by Article 7(3) of Decision 93/731. ${ }^{27}$ They later wrote to the General Secretariat to make another confirmatory application, pursuant to Article 7(2) of Decision $93 / 731,{ }^{28}$ in relation to the minutes of the Agriculture Council. $^{29}$ The Council replied to the applicants in a letter of 17 May 1994, saying that access to the Justice Council's documents in question "cannot be allowed", or "the Council would fail to protect the confidentiality of its proceedings". It said the documents contained "confidential information relating to the position taken by the members of the Council during its deliberations". ${ }^{30}$

The Council said in the letter that similar considerations of confidentiality applied to the Social Affairs Councils' preparatory reports, minutes and voting records in question, and "which in fact should not have been sent to you", adding that they were "sent to him because of an administrative error". It said access to the Agriculture Council's minutes should not be allowed for the same reasons. ${ }^{31}$ The applicants then brought the present action. ${ }^{32}$ They were supported by the Danish and Dutch Governments and the European Parliament. ${ }^{33}$ They claimed that the Court should:

(1) annul the decision whereby the Council refused to grant them access to the Justice Council's documents at issue;

${ }^{27}$ para. 20, n. 18 above. Article 7(3) of Decision 93/731 provides that:

Any decision to reject a confirmatory application, which shall be taken within a month of submission of such application, shall state the grounds on which it is based. The applicant shall be notified of the decision in writing as soon as possible and at the same time informed of the content of Articles 138e and 173 of the Treaty establishing the European Community (now Articles 195 and $230 \mathrm{EC}$ ), relating respectively to the conditions for referral to the Ombudsman by natural persons and review by the Court of Justice of the legality of Council acts.

28 Article 7(2) of Decision 97/731 states that "[f]ailure to reply to an application within a month of submission shall be equivalent to a refusal, except where the applicant makes a confirmatory application, as referred to above, within the following month".

29 para. 21 , n. 18 above.

30 para. 22 , n. 18 above.

31 para. 22 , n. 18 above.

32 para. 23 , n. 18 above.

33 para. 24 , n. 18 above. 
(2) annul the decision of 17 May 1994 whereby the Council refused to grant them access to the Agriculture Council's minutes in question and that to the documents of the Social Affairs Councils. ${ }^{34}$

The Council contended that the Court should dismiss the application as unfounded. ${ }^{35}$ The applicants put forward the pleas that allege:

(1) breach of the fundamental principle of Community law of access to the documents of the institutions of the Union;

(2) breach of the principle of the protection of legitimate expectations;

(3) infringement of Article 4(2) of Decision 93/731 inasmuch as the contested decisions are the expression of a blanket refusal to allow access to certain types of document. ${ }^{36}$

The applicants said the Council had expressed a blanket refusal to grant access to documents which related to its deliberations. They said such refusal infringed Article 4(2) of Decision 93/731. In their view, this provision implied that the Council must carefully balance the interests involved before deciding whether access to a document was to be refused. ${ }^{37}$ They stated that no balancing of interests took place before the Council decided to reject their confirmatory application. ${ }^{38}$ They added that "the confidentiality of deliberations [was] only one of the interests to be taken into account when applying the general principle of access to the institutions'

\footnotetext{
34 para. 27 , n. 18 above.

35 para. 28 , n. 18 above.

36 para. 36, n. 18 above.

37 para. 43 , n. 18 above.

${ }_{38}$ para. 43, n. 18 above.
} 
documents". 39

In response, the Council, first of all, said the applicants had adduced no evidence to support their allegation that the Council did not balance the interests involved. ${ }^{40}$ The Council went on to say that Decision $93 / 731$, being based on the Council's Rules of Procedure, must be construed according to the legislation. In its view, "[u]nder Article 5(1) of its Rules of Procedure, ${ }^{41}$ the deliberations of the Council are in principle protected against disclosure, although the Council may decide otherwise". ${ }^{42}$

The Council denied that it had expressed a blanket refusal to grant access to documents related to its deliberation. It said it was "always open to it to make use of the derogation provided for in its Rules of Procedure and to decide to disclose documents relating to its proceedings", ${ }^{43}$ adding that it had "made a proper evaluation of the interests to be balanced". ${ }^{44}$ It described in detail the decision-making process which resulted in the refusal, ${ }^{45}$ without elaborating on how the interests were balanced. Outlining the reasons underlying the principle of the confidentiality of its proceedings, it emphasised that:

This process of compromise and negotiation is vital to the adoption of Community legislation, and would be jeopardised if delegations were constantly mindful of the fact that the positions they were taking, as recorded in Council minutes, could at any time be made public through the granting of

\footnotetext{
${ }^{39}$ para. 44 , n. 18 above. 40 para. 46 , n. 18 above.

${ }_{41}$ Article 5(1) of the Rules of Procedure provides that "[w]ithout prejudice to Article 7(5) and other applicable provisions, the deliberations of the Council shall be covered by the obligation of professional secrecy, except in so far as the Council decides otherwise".

42 para. 47 , n. 18 above.

43 para. 48 , n. 18 above.

${ }_{45}$ para. 49 , n. 18 above.

${ }^{45}$ para. 50, n. 18 above.
} 
access to those documents. ${ }^{46}$

\subsubsection{Held}

The applicants contested the decision which they considered to be contained in the Council's letter of 17 May 1994, refusing them access to the Social Affairs Councils' documents in question. The Court, however, ruled that this claim was inadmissible "since no decision to refuse them access thereto was ever adopted by the Council". 47 However, the Court said the letter had constituted the decision refusing the applicants access to the minutes of the Agriculture Council, because the Council explained in the letter why it had decided not to allow them access to the minutes of the Agriculture Council. ${ }^{48}$ Second, the Court stressed that Council Decision 93/731 was “the only measure governing citizens' rights of access to (Council) documents; the Council's Rules of Procedure, on the other hand, regulate its own internal operating mechanisms". ${ }^{49}$ It then examined the third of the applicants' pleas, stating that:

It is clear both from the terms of Article 4 of Decision 93/731 and from the objective pursued by that decision, namely to allow the public wide access to Council documents, that the Council must, when exercising its discretion under Article 4(2), genuinely balance the interest of citizens in gaining access to its documents against any interest of its own in maintaining the confidentiality of its deliberations. ${ }^{50}$

\footnotetext{
${ }^{46}$ para. 52, n. 18 above.

${ }_{47}$ para. 35 , n. 18 above.

48 paras. 38 and 39, n. 18 above.

49 para. 62, n. 18 above.

50 para. 65 , n. 18 above.
} 
The Court said such interpretation of Article 4(2) was consistent with the Code of Conduct which the Council decision was intended to implement, ${ }^{51}$ adding that "whenever access to documents is requested, the Council must balance the interests defined above and reach a decision in accordance with the applicable procedure". ${ }^{52}$

The Court stated that the two letters sent to the applicants on 28 February 1994 and 17 May 1994 by the General Secretariat of the Council, showed that the Council, when responding to the applicants' requests, did not comply with the obligation of balancing the interests involved, laid down by Article 4(2) of Decision 93/731. ${ }^{53}$ The Court said the terms of the letters indicated that the Council had considered both that it was obliged to refuse access to the documents in question, merely because they referred to its deliberations and that disclosure of the documents requested by the applicants would involve a breach of its Rules of Procedure, in particular of Article 5.

The Court continued to say that the Council's incorrect interpretation of the relevant provisions was illustrated by the phrases used in the letter of February 1994, as the General Secretariat told the applicants that "I am unable to send you these documents, since they ... cannot ... be disclosed", and in that of May 1994, because the Council said "... access to these documents cannot be allowed ....". The Court said the phrases indicated that the Council had considered that it did not have the option of disclosing the documents requested. ${ }^{54}$ In addition, it said the Council "did not adduce any concrete evidence capable of establishing that it did assess the specific competing interests". ${ }^{55}$ Therefore, it upheld the third plea advanced by the

\footnotetext{
${ }^{51}$ para. 66, n. 18 above.

52 para. 67, n. 18 above.

53 para. 73 , n. 18 above.

${ }_{54}$ para. 73 , n. 18 above.

55 para. 77, n. 18 above.
} 
applicant ${ }^{56}$ and concluded that "[ $\left.t\right]$ he contested decisions must therefore be annulled, without there being any need to examine the other pleas advanced by the applicants". 57

\subsubsection{Comment}

First, the present case mainly concerned the scope of the discretionary exception laid down in Article 4(2) of Council Decision 93/731. This provision, in the view of the applicants, implied that the Council must carefully balance the interests involved before deciding whether access to a document was to be refused. But actually this provision did not, at least not expressly, put the Council under such obligation. It only stated that "[a]ccess to a Council document may be refused in order to protect the confidentiality of the Council's proceedings". These terms provided the Council with a discretionary exception where they wished to defend the confidentiality of their proceedings, without elaborating on the scope of this exception.

The Court accepted the view of the applicants after examining Article 4 of Decision 93/731 and the objective of this Decision. The Court said the rules and objective revealed that "the Council must, when exercising its discretion under Article 4(2), genuinely balance the interest of citizens in gaining access to its documents against any interest of its own in maintaining the confidentiality of its deliberations". It added that such an interpretation of Article 4(2) was consistent with the provisions of the Code of Conduct, which Decision 93/731 was intended to

\footnotetext{
${ }_{57}^{56}$ para. 79, n. 18 above.

57 para. 80 , n. 18 above.
} 
implement. The Court addressed this case mainly by setting the limit to the exception before making an effort to determine whether relevant interests were balanced in the case. As the two letters from the Council indicated that it had considered that it was obliged to refuse access to the documents in question, the Court annulled the decisions at issue.

Attention should also be drawn to the term "the provisions of the Code of Conduct", because the Court did not explain what these provisions were and why its interpretation was consistent with them. The provisions at issue presumably include the general principle of the Code of Conduct set out in its first section, which provided that "[t]he public will have the widest possible access to documents held by the Commission and the Council". Nevertheless, as we have seen in 3.1.2, the extensive exceptions laid down in both the Code of Conduct and Decision 93/731 showed that the "widest possible access to documents" could be limited in reality.

The judgment reveals an attempt on the part of the judges to remedy the deficiency of both the Code of Conduct and Decision 93/731. It was the Court, rather than the two measures, that set the limit to the exception. Professor Carol Harlow has said "Carvel was a breakthrough in establishing the justiciability of the Code of Conduct; it was equally important in establishing that decision-making under the Code (of Conduct) in respect of Third Pillar documents was subject to review by the CFI" ${ }^{58}$ The judgment is indeed revolutionary in the FOI field, but it is also important to appreciate the limited nature of the judgment in favour of the applicants. The Court only demanded that the Council properly exercise its discretion rather than issuing a blanket refusal, but it made no effort to prevent the Council from concluding that the interests of confidentiality outweighed the public's right of

${ }^{58}$ Harlow, n. 7 above, at 163 and 164 . 
access.

The applicants said the blanket refusal had constituted a breach of the fundamental principle of Community law of access to the documents of the institutions of the Union. The CFI, however, only examined the third plea of the applicants before it decided to annul the contested decisions. It added that there was no need to examine the other pleas advanced by the applicants. The CFI avoided determining whether access to documents was a fundamental right. Crucially, the Court made no statement about access rights in general.

The Council obviously thought that such requests fell within the field of internal affairs, as it said that Decision 93/731 must be construed according to the Rules of Procedure, adding that "[u]nder Article 5(1) of its Rules of Procedure, the deliberations of the Council are in principle protected against disclosure, although the Council may decide otherwise”. The CFI said that Decision 93/731 was the only measure governing citizens' rights of access; the Council's Rules of Procedure regulated its internal mechanisms. It added that access should not have been refused merely because it involved a breach of its Rules of Procedure, in particular of Article 5. This dispute once again revealed that the Union needed general rules on FOI protection and such legislation should not have been based on rules of internal affairs.

In addition, the Council argued that a process of negotiation was vital to the adoption of EC legislation. It said such a process would be jeopardised if delegations were constantly mindful of the fact that the positions they were taking could be made public through the granting of access to those documents. This statement showed that policy-makers would be fearful if their positions could be made public. The CFI made no direct statement about such fear, but its conclusion suggested that the judges 
believed that the right of access right prevailed over prevention of such fear.

Fear is a form of "cost" in the FOI field. Professor Patrick Birkinshaw says that "[t]here is the fear of perpetual intervention when policy-makers are constantly exposed or challenged and have to justify their every move. In such a situation individuals may not wish to take risks or make innovative decisions. The cost could be a reduction in professionalism". ${ }^{59}$ This and the other forms of $\operatorname{cost}^{60}$ will be carefully considered throughout this study, especially when analysing the relevant legislation and case law. It is not surprising that the Council and Commission attempt to use these cost factors in argument against release of information, but it should be noted that these concerns should not be employed as the basis for a general refusal.

\subsection{The 1996 Netherlands judgment ${ }^{61}$}

The Commission and Council implemented the Code of Conduct but in doing so followed very different approaches. The Commission simply adopted this instrument and elaborated procedural rules concerning application for access to documents in Commission Decision 94/90. ${ }^{62}$ The Council Decision 93/731 was, however, adopted

\footnotetext{
${ }^{59}$ P. Birkinshaw, Freedom of Information, The Law, the Practice and the Ideal $\left(3^{\text {rd }}\right.$ edn., London, Butterworths, 2001), 61.

${ }^{60}$ For instance, there is the cost of opening up operations relating to national security, because openness in this area could be destructive of citizens' security. In addition, there is also the financial cost of freedom of information. This is because the public's demand for information requires civil servants to address requests and all the other relevant matters.

${ }^{61}$ Case C-58/94, Netherlands v. Council [1996] ECR I-2169.

${ }^{62}$ Article 1 of Commission Decision 94/90 states that "[t]he code of conduct on public access to Commission documents set out in the Annex is adopted". n. 2 above.
} 
on the basis of Article 151(3) $\mathrm{EC}^{63}$ (now Article 207(3) EC) and the Council's Rules of Procedure, particularly Article $22 .{ }^{64}$ This Council Decision was controversial, because, first, the general principle of the Code of Conduct that "[t]he public will have the widest possible access to documents held by the Commission and the Council" was not included. However, Article 1(1) of Council Decision 93/731 states that "[t]he public shall have access to Council documents under the conditions laid down in this Decision". Though this does not use the phrase "widest possible access", it does not explicitly reject this principle. This is an important principle in guiding the Community court especially in circumstances where there are conflicts between protection of freedom of information and other interests.

Second, further exceptions to openness were laid down in addition to the already extensive exceptions in the Code of Conduct. For instance, Article 8 of Decision 93/731 provided that "[t]his Decision shall apply with due regard for provisions governing the protection of classified information", which is an additional exception not found in the Code of Conduct. It was, therefore, not difficult to realise why the Netherlands, which consistently pushed the FOI issue in relation to governance of the Community, would regard the exceptions contained in the Code of Conduct, Decision 93/731, and Article 22 of the Council's Rules of Procedure, as dangerously extensive rules. Within two months of the adoption of Decision 93/731, the Netherlands requested the ECJ to annul the measures in Netherlands v. Council, a case which raised key questions of principle. $^{65}$

63 Former Article 151(3) EC provides that "[t]he Council shall adopt its rules of procedure".

${ }^{64}$ Council Decision of 6 December 1993 adopting the Council's Rules of Procedure, 93/622/EC [1993] OJ L304/1. Article 22 of the Rules of Procedure states that "[t]he detailed arrangements for public access to Council documents disclosure of which is without serious or prejudicial consequences shall be adopted by the Council".

65 n. 61 above. 


\subsubsection{Facts}

By application lodged at the ECJ on 10 February 1994, the Netherlands, supported by the European Parliament, brought an action under Article 173 EC (now Article 230 EC) for annulment of the Code of Conduct, Council Decision 93/731, and Article 22 of Council's Rules of Procedure. The Council claimed that the intervention by the Parliament should be declared inadmissible as it did not have "the same object as the Netherlands Government's application". ${ }^{66}$ In response, the Parliament based its intervention on the following arguments:

(1) By basing the contested rules on its power to organise its internal operation, the Council arrogated to itself the power to determine the extent in which its legislative proceedings are accessible to the public and thereby misused the powers conferred on it by Article 151(3) EC (now Article 207(3) EC). ${ }^{67}$

(2) The principle of openness of the legislative process and the access to legislative documents entailed could not be treated as organisational matters purely internal to the institutions as they constituted essential requirements of democracy. ${ }^{68}$

(3) The right to information, of which access to documents constituted the corollary, had been a fundamental human right recognised by various international instruments. ${ }^{69}$

\footnotetext{
${ }_{67}^{66}$ para. 15, n. 61 above.

${ }^{67}$ para. 17, n. 61 above.

68 para 18, n. 61 above.

69 para. 18, n. 61 above.
} 
The Netherlands stated that the Code of Conduct did not constitute an act having legal effects as it was not an act within the meaning of Article $189 \mathrm{EC}^{70}$ (now Article 249 EC) or any act provided for elsewhere in the Treaties, but "a text of a political nature setting out political agreements". Nonetheless, the Netherlands stressed inconsistently that "[ $\mathrm{t}]$ he Code should be held to be a decision in its own right having legal effects, that it should be annulled in so far as, contrary to the requirements of Article $190^{71}$ [now Article 253] of the EC Treaty, it contains no reference to its legal basis". 72

The Dutch government sought annulment of Decision $93 / 731$ by arguing that the Council had wrongly used former Article 151(3) EC and Article 22 of its Rules of Procedure as the legal basis for that decision, as they had been concerned "solely in the Council's internal organisation". ${ }^{73}$ The Netherlands said the contested decision had gone far beyond the sphere of application of the rules on the internal organisation and management of the Council and had constituted an act expressly designed to have effects vis-à-vis citizens, adding that public access to Council documents had constituted the basic principle of the decision (Article 1 of the Code of Conduct) and that legal effects may arise vis-à-vis individuals. ${ }^{74}$ The Netherlands conceded that internal measures may exceptionally have external effects. However, it stressed that as "the very purpose of the rules is to create rights in individuals, the rules in

\footnotetext{
70 The first paragraph of former Article $189 \mathrm{EC}$ provides that "[i]n order to carry out their task and in accordance with the provisions of this Treaty, the European Parliament acting jointly with the Council, the Council and the Commission shall make regulations and issue directives, take decisions, make recommendations or deliver opinions".

${ }^{71}$ Former Article $190 \mathrm{EC}$ states that "[r]egulations, directives and decisions adopted jointly by the European Parliament and the Council, and such acts adopted by the Council or the Commission, shall state the reasons on which they are based and shall refer to any proposals or opinions which were required to be obtained pursuant to this Treaty".

72 para. 23 , n. 61 above.

${ }_{73}$ para. 28, n. 61 above.

74 para. 29, n. 61 above.
} 
question may not be adopted on the basis of provisions authorising the Council to adopt measures relating to its internal organisation and functioning". ${ }^{75}$ The Netherlands also argued that the Council's exclusion of the Parliament in addressing the question of open government had infringed the balance among the institutions defined in Article $4 \mathrm{EC}^{76}$ (now Article $7 \mathrm{EC}$ ). ${ }^{77}$

Finally, to seek annulment of Article 22 of the Rules of Procedure, the Netherlands said the purpose of this provision greatly exceeded the confines of the rules governing the internal organisation of the Council, with the result that it could not form part of a body of provisions intended solely to set out rules on the internal organisation and management of an institution. It maintained that the Council had infringed former Article 151(3) EC, or at least misused the power conferred on it by those provisions by adopting Article 22 of its Rules of Procedure. ${ }^{78}$

\subsubsection{The Advocate General's opinion}

Advocate General Tesauro said that "[i]t may be considered that the right of access to information is increasingly clearly a fundamental civil right". ${ }^{79} \mathrm{He}$ also said that "a link is made between the right to access to documents in the possession of the public authorities and the right to freedom of expression and to receive and impart information enshrined in Article 10 of the European Convention for the Protection of

\footnotetext{
75 para. 30 , n. 61 above.

76 The second paragraph of former Article 4 provides that "[e] $]$ ch institution shall act within the limits of the powers conferred upon it by this Treaty".

77 para. 32, n. 61 above.

78 para. 42 , n. 61 above.

79 point 16.
} 
Human Rights and Fundamental Freedoms". ${ }^{80}$ He continued to say that: "[t]hat right, as the European Parliament rightly points out, constitutes a corollary of the freedom to seek, receive and disseminate information and ideas of every kind guaranteed by Article 19 of the International Covenant on Civil and Political Rights, signed at New York on 19 December 1966". 81

He said that "[c]onsequently, we are witnessing, also on the level of the law of international conventions as in the legislation of the Member States, a progressive, increasingly broader affirmation of the individual's right of access to official information". ${ }^{82}$ He stressed that the basis for an individual right to information "should be sought in the democratic principle, which constitutes one of the cornerstones of the Community edifice". ${ }^{83}$ However, he proposed that the Court should declare the application for annulment inadmissible ${ }^{84}$ mainly because the Code of Conduct was an "agreement essentially of a policy nature", 85 and that the Council and Commission were authorised, "pursuant to the power of self-regulation vested in each of them, to lay down rules independently in this sphere governing the aspects more directly concerned with the procedures and conditions for examining

${ }^{80}$ Ibid. The first paragraph of Article 10 ECHR provides that "[e]veryone has the right to freedom of expression. This right shall include freedom to hold opinions and to receive and impart information and ideas without interference by public authority and regardless of frontiers".

${ }_{81}$ point 16. This Covenant entered into force on 23 March 1976. As at November 1999, 144 states have ratified this Covenant. M. Dixon and R. McCorquodale, Cases and Materials on International Law ( ${ }^{\text {rd }}$ edn., London, Blackstone Press, 2000), 198. Article 19 of the Covenant states that:

1. Everyone shall have the right to hold opinions without interference.

2. Everyone shall have the right to freedom of expression; this right shall include freedom to seek, receive and impart information and ideas of all kinds, regardless of frontiers, either orally, in writing or in print, in the form of art, or through any other media of his choice.

3. The exercise of the rights provided for in paragraph 2 of this article carries with it special duties and responsibilities. It may therefore be subject to certain restrictions, but these shall only be such as are provided by law and are necessary:

(a) For respect of the rights or reputations of others;

(b) For the protection of national security or of public order (ordre public), or of public health or morals.

point 16 .

point 19 .

point 25 .

85 point 23. 
applications for access". 86

\subsubsection{Held}

The Court first declared the intervention by the Parliament admissible since the Parliament sought to show the Council had exceeded the powers of its internal organisation conferred on it by Article 151(3) EC (now Article 207(3) EC). The Court said that the Parliament's argument was in common with that of the Netherlands. ${ }^{87}$ It then ruled on the application for annulment of the Code of Conduct. It stated that "an action for annulment must be available in the case of all measures adopted by the institutions, whatever their nature or form, which are intended to have legal effects" ${ }^{88}$ It continued to say that it had appeared, in particular from the Code of Conduct's preamble and its fifth section entitled "implementation", that "the Code of Conduct merely foreshadows subsequent decisions intended, unlike the Code, to have legal effects" ${ }^{89}$ The Court, therefore, dismissed the application for annulment of the Code of Conduct, because "the Code is an act which is the expression of purely voluntary coordination and is therefore not intended in itself to have legal effects". 90

Thirdly, the Court did not accept the Dutch government's arguments for annulment of Decision 93/731. It stated that at Community level the importance of a right to access had been reaffirmed on various occasions, adding that "[i]t was in

point 22 .

87 paras. 20,21 , and 22, n. 61 above.

88 para. 24, n. 61 above.

89 para. 26, n. 61 above.

90 para. 27, n. 61 above. 
order to conform to this trend, ... that the Council deemed it necessary to amend the rules governing its internal organisation, which had hitherto been based on the principle of confidentiality". ${ }^{91}$ It elaborated on why the Council should be empowered to make the decision in question. It stated that:

So long as the Community legislature has not adopted general rules on the right of public access to documents held by the Community institutions, the institutions must take measures as to the processing of such requests by virtue of their power of internal organisation, which authorises them to take appropriate measures in order to ensure their internal operation in conformity with the interests of good administration. ${ }^{92}$

The Netherlands said the contested decision had constituted an act expressly designed to have legal effects vis-à-vis citizens, but the Court said that there was nothing to prevent rules on the internal organisation of an institution's work from having such effects. ${ }^{93}$ Consequently, the Court said that, as EC law stood at that time, the Council was empowered to adopt measures intended to address requests for access to documents in its possession. ${ }^{94}$ The Court, therefore, said that the Council had not circumvented any procedure specially provided for by the Treaty to address circumstances of this kind and hence was not guilty of any misuse of power. ${ }^{95}$

In response to the plea alleging infringement of the principle of institutional balance, the Court said the fact that Decision 93/731 "did not involve the Parliament in its adoption cannot detract from the Parliament's prerogatives, which include participation, where provided for in the Treaties, in the process of the drafting of

91 para. 35 , n. 61 above.

92 para. 37, n. 61 above.

93 para. 38, n. 61 above.

94 para. 39 , n. 61 above.

95 para. 40, n. 61 above. 
legislative measures". ${ }^{96}$ As to the application for annulling Article 22 of the Council's Rules of Procedure, the Court said the arguments by the Netherlands could not be upheld because "the measures in question are among those which, as Community law stands at present, an institution is empowered to take pursuant to its

power of internal organisation". 97 The Court, therefore, dismissed the application for annulling the Code of Conduct, Decision 93/731, and Article 22 of the Rules of Procedure.

\subsubsection{Comment}

This subsection examines the views of the Court summarised as follows:

(1) The Code of Conduct has no legal effects.

(2) As the Code of Conduct has no legal effects, it is fair to say the Community legislature has not adopted general rules on freedom of information.

(3) There are no general rules, so the Council and Commission must deal with the issue under their powers of internal organisation.

(4) The contested acts should not be annulled because these powers authorised the institutions to take appropriate measures.

\subsubsection{Legal effects}

The first view is very important since the three others are closely related to it. Considering the indistinct line between a political statement and a legal measure, the

${ }_{97}$ para. 41, n. 61 above.
para. 43, n. 61 above. 
Court held that the Code of Conduct was an instrument of no legal effect by interpreting the term "legal effect" in a narrow manner. However, it should be noted that the Code of Conduct had a normative quality as the Council and Commission saw it as obliging them to adopt the two corresponding decisions, though it did not have full enforceable quality or have a direct impact on citizens in the Union. Second, the Court addressed the case technically when it defined the Code of Conduct as just an "agreement" or "simply the expression of purely voluntary coordination" without legal effects.

The Court lost sight of the fact that the Commission simply adopted the Code of Conduct without making any change in this "agreement". The adoption by the Commission indicated that the Code of Conduct was capable of having a normative quality, as the Commission adopted it without altering the language used in the measure. In addition, in their request for access to information held by the Commission, citizens of the Union would apply Commission Decision 94/90 directly and the Code of Conduct in an indirect manner, as the latter became an annex to the former. The language used in the Code of Conduct was not purely political but introduced rules capable of being enforced, though the Court was right in recognising the instrument to be a non-binding act on a strictly literal interpretation of its nature.

\subsubsection{General rules}

The Court insisted that, as the Code of Conduct had no legal effect, it was fair to say that the Community legislature had not adopted general rules on freedom of information. This statement was not entirely clear because the Court made use of the phrase "general rules" without explaining what it envisaged these rules were. They could be provisions in a FOI regulation, as a regulation has "general application", 
according to Article $189 \mathrm{EC}$ (now Article $249 \mathrm{EC}$ ). ${ }^{98}$ These rules could also take the form of a regulation coupled with an express provision in the EC Treaty. The latter alternative is presumably what the Court had in mind, as the two types of rule would definitely help the Court deal with disputes over public access with less difficulty.

Secondly, this vague statement by the Court can also be considered controversial when we examine the preamble of the Code of Conduct, in which the Council and Commission stated that they adopted the measure with regard to the conclusion of the Copenhagen European Council. In June 1993, participants at the summit asked the Council and Commission to continue the realisation of access to information, adding that " $[\mathrm{t}]$ he aim should be to have all necessary measures in place by the end of 1993". The term "all necessary measures" expressly revealed that the two institutions were expected to adopt legally binding general rules and those designed to implement the guidelines by the end of 1993. If there was no general rule in the Code of Conduct, could we say the two institutions had failed to meet the expectations of the Copenhagen European Council?

\subsubsection{Power of internal organisation}

The third point made by the Court was that, as the Community legislature had not adopted general rules on freedom of information, the Council was entitled to use its power of internal organisation to take appropriate measures to address the issue.

First, after the Court took the view that the Code of Conduct did not establish legally binding general rules, it made another statement that permitted the Council to address freedom of information issues by its power of internal organisation. It stated

\footnotetext{
98 Article 249(2) EC provides that "[a] regulation shall have general application. It shall be binding in its entirety and directly applicable in all Member States".
} 
that, as the Community legislature had not adopted any general rules, the Council and Commission must take measures as to the processing of such requests by virtue of their power of internal organisation. This statement showed that the Court laid the primary responsibility to act firmly on legislative shoulders. In other words, the Court insisted that any further action to delineate a right of access must await the legislature's further intervention. This view was insufficient to help resolve the dispute. This is because, under the so-called "co-decision procedure" or "joint legislative procedure", 99 the Council shares legal responsibility for legislation with the Parliament. ${ }^{100}$ This meant that, with the permission of the Court, the Council would be able to continue to address requests for access to information by its internal rules, such as Decision 93/731, if it declined to adopt general rules, within the definition of the Court. Therefore, the Council should not have been entitled by the Court to use its power of internal organisation to deal with the issue.

Second, the ECJ's permission revealed that a Council decision based on the power of internal organisation would not be annulled even if this measure was designed to have legal effects vis-à-vis citizens. The philosophy behind this permission was that freedom of information was simply an extension of the requirements of good administration rather than an outcome of the belief in participatory democracy. Third, the Court wrongly recognised the Council's amendment of the internal rules as an effort to respond to the trend in favour of more access to information. If the Council had intended to conform to this trend, it would

\footnotetext{
99 This procedure is laid down in Articles 251 EC (ex Article 189b EC), which is a provision inserted into the EC Treaty by the EU Treaty and modified by the Treaty of Amsterdam.

${ }^{100}$ In addition, under the co-decision procedure, the interaction - between the Commission as the instigator of proposals and the Council wielding the power of final decision - remains central under EC procedures that either do not involve the Parliament at all, or merely give it the right to be consulted and to render a non-binding Opinion. A. Dashwood, 'Issues of Decision-making in the European Union after Nice' in A. Arnull and D. Wincott (eds.), Accountability and Legitimacy in the European Union (Oxford, Oxford University Press, 2002), 23.
} 
have adopted the Code of Conduct without laying down the additional exceptions in Article 4. The Court did not appear to accept that the Council had attempted to halt rather than conform to the trend.

The ECJ concluded that the contested acts should not be annulled, as the internal power authorised the institutions to take appropriate measures "to ensure their internal operation in conformity with the interests of good administration". The ECJ permitted the Council to safeguard the "interests of good administration", without explaining why such interests prevailed over freedom of information. In addition, this conclusion indicated that the Court unrealistically believed the Council and Commission were capable of taking proper measures. The fact was that both the Decision 93/731 and Article 22 of the Council's Rules of Procedure were not perfect, as they did not greatly help to improve the democratic order of the Union. In other words, we should not expect the Council to oblige itself to face democratic scrutiny.

The ECJ held the view that nothing prevented rules concerning the internal organisation of an institution from having effects vis-à-vis third parties. But whether a Council decision, which was based on internal power and designed mainly to have effects vis-à-vis citizens, should be annulled is a distinct question. This was exactly the question asked by the Netherlands, but the Court did not respond to it. In other words, the ECJ did not elaborate on whether it was appropriate for the Council to address FOI issues by means of internal rules.

In response to the plea alleging infringement of the principle of institutional balance, the Court said that "the fact that it did not involve the Parliament in its adoption cannot detract from the Parliament's prerogatives, which include participation, where provided for in the Treaties, in the process of the drafting of legislative measures". The Court approved the Council's notable exclusion of the 
Parliament's input in the legislative procedure, which were listed in the Code of Conduct. This statement also suggested that the Parliament had not been barred from adopting a measure to address FOI-related issues. However, the ECJ did not face the challenge by the Netherlands, as it did not respond to whether the Council and Commission's exclusion of the Parliament's input had constituted a subversion of the EU's democratic processes.

The Parliament contributed to EU FOI protection via its support to the Netherlands in the present case. Its arguments expressly showed the intention to facilitate access to information. The efforts revealed the Parliament's perception of itself as representing democratic accountability in a wide sense.

\subsubsection{Right of access as a fundamental right}

Some writers have said that the present case is a technical one as the Netherlands contested the legal basis of Decision $93 / 731,{ }^{101}$ but the philosophy behind the argument is that freedom of information should be considered a fundamental right. A Danish official said that "[t]he true purpose of the Dutch government's action was not simply to obtain a declaration of nullity from the Court. On the contrary, the Government sought recognition from the Court that access to documents is one of the citizens' fundamental rights". ${ }^{102}$ Indeed, in addition to the contest to Decision 93/731's legal basis, the Netherlands also stressed that "the Council wrongly categorised as a matter of internal organisation something which in fact constitutes a

\footnotetext{
${ }^{101}$ For example, Professors Deirdre Curtin and Herman Meijers have said that " $[t]$ his is a technical case with the Dutch government relying heavily on the fact that the rules of procedure of an institution are not apt to include provisions or to provide the legal basis for provisions which confer rights on their parties". D. Curtin and H. Meijers, 'Access to European Union Information: an Element of Citizenship and a Neglected Constitutional Right' in N. Neuwahl and A. Rosas (eds.), The European Union and Human Rights (The Hague, Martinus Nijhoff, 1995), 92.

${ }^{102}$ M. Broberg, 'Access to Documents: a General Principle of Community Law?' (2002) 27 European Law Review 199.
} 
fundamental right, namely the public's right of access to information".

Although both the Netherlands and Advocate General Tesauro, as we have seen, raised the key questions concerning a legal right of access, the Court made no response to the issues. It addressed the case in a technical manner, repeatedly avoiding a direct response to the claims regarding the existence of a fundamental right. Professor Patrick Birkinshaw says that "[i]t appeared that the ECJ had failed to rise to the challenge of the advocate general who argued for a legal, indeed a constitutional right of access". ${ }^{103}$ To declare the application for annulment of the Code of Conduct inadmissible, the Court interpreted the term "legal effects" in a narrow sense after considering the hazy line between legal and political instruments. It ruled that the Council was empowered by EC law at that time to adopt the measures intended to address requests for access to documents in its possession.

Two choices were before the Court when addressing this present case. It had the choice to declare access to information a fundamental right before annulling the Code of Conduct, Decision 93/731, and Article 22 of the Rules of Procedure. Or the Court could both rule the Dutch government's application inadmissible and wait for a future recognition of the right of access in the EC Treaty. If the Court had taken the former option, the Council would have had to cooperate with the other major EU institutions in addressing the issue by drawing up one of the measures listed in Article 189 (now Article 249) of the Treaty, presumably a regulation. This would definitely have accelerated FOI protection in the Union. The Court, however, took the latter option. It enabled the Council and Commission to subvert the Union's democratic processes by proceeding through the Code of Conduct to exclude input from the Parliament. A writer has said that "[o]n a positive note, while the Court did

${ }^{103}$ Birkinshaw, n. 59 above, at 366-367. 
not examine the issue of the nature of the public's right of access, it certainly left the door open for future judicial developments in this area". ${ }^{104}$

Although the Court made such a decision, it did not mean that the Court had failed to realise the significance of the fundamental right at issue. In fact, the Court stressed that at Community level the importance of the right of access had been reaffirmed on various occasions, though the judges did not go on to recognise this right as a fundamental right. It should be noted that it was extremely difficult for the Court to deliver a revolutionary judgment recognising this right. This was because there was only Declaration 17 to the Maastricht Treaty, rather than express provisions on freedom of information in the constitutive Treaties. A declaration's status is not entirely clear. $^{105}$ Thus, if the Court had decided to annul the contested rules, it would have had to elaborate on the nature of freedom of information in its judgment. It was not surprising that the judges then chose to address the case technically and wait for a future adoption of general rules, which could take, as we have seen, the form both of express provisions in the EC Treaty along with a specific FOI regulation.

\subsection{The WWF case $\mathrm{c}^{106}$}

In Carvel, the CFI addressed the scope of the discretionary exception set out in

\footnotetext{
${ }^{104}$ M. O'Neill, 'The Right of Access to Community - Held Documentation as a General Principle of EC Law' (1998) 4 European Public Law 412.

${ }^{105}$ Professor Trevor Hartley has said that "status of the declarations annexed to the Treaties - some of which are joint declarations on the part of all the Contracting States and some of which are unilateral declarations by one Contracting State only - is not entirely clear". T. Hartley, The Foundations of European Community Law (5 $5^{\text {th }}$ edn., Oxford, Oxford University Press, 2003), 94. Although some declarations have indirect legal effects, many others were obviously of political significance alone. ${ }^{106}$ Case T-105/95, WWF (United Kingdom) v. Commission [1997] ECR II-313.
} 
Article 4(2) of Council Decision 93/731, a provision corresponding to the fourth section, second subsection of the Code of Conduct. In its judgment, the Court said that "the Council must, when exercising its discretion under Article 4(2), genuinely balance the interest of citizens in gaining access to its documents against any interest of its own in maintaining the confidentiality of its deliberations". It demanded that the Council strike a genuine balance between relevant interests when applying the second category of discretionary exception set out in the Code of Conduct and Decision $93 / 731$. But what was the scope of the first category of mandatory exceptions laid down in these measures? ${ }^{107}$ Is the Council or Commission allowed to refuse requests by invoking these two categories of exception concurrently? In the WWF judgment, the CFI set out the conditions to be met by the Commission when attempting to invoke these two categories simultaneously.

\subsubsection{Facts}

The Irish authorities planned to use structural funds to build a visitors' centre at Mullaghmore in the west of Ireland. The applicant, WWF UK (World Wide Fund for Nature), a trust incorporated under English law, complained to the European Commission, objecting that this project would infringe EC environmental law and involved a wrongful application of structural funds. ${ }^{108}$ The Commission's

\footnotetext{
107 The mandatory exceptions laid down in Article 4(1) of Council Decision 93/731 mainly corresponded to those in the fourth section, first subsection of the Code of Conduct. This subsection couched the list of exemptions in mandatory terms; access will be denied where disclosure could undermine the various rights and interests, such as privacy and public interest.

108 para. 10, n. 106 above.
} 
investigation indicated that this proposal did not infringe EC law. ${ }^{109}$ By two letters written to the Directors General of DG XI (Environment) and DG XVI (Regional Policies), the applicant, relying on Commission Decision 94/90, requested access to "all Commission documents relating to the examination of the Mullaghmore project". ${ }^{110}$ By two letters, an official within DG XI and the Director General of DG XVI informed the applicant of the refusal. ${ }^{111}$

The applicant submitted confirmatory applications according to the Code of Conduct, ${ }^{112}$ to the Secretary General of the Commission, ${ }^{113}$ who replied by a letter dated 2 February 1995, in which he reconfirmed the refusals made by the DG XI and DG XVI, ${ }^{114}$ saying that "[t]he fundamental principle guiding the consideration of each request is that the public will have the widest possible access to documents held by the Commission, albeit with certain exemptions to protect public and private interests which could be damaged if access to certain documents were permitted, and to ensure that the Commission can deliberate in confidence". ${ }^{115} \mathrm{He}$ said that "it is indispensable for the Commission to ensure that a climate of mutual confidence is maintained, which would risk being severely disrupted by publicity". 116

The applicant then brought the action before the CFI. ${ }^{117}$ The applicant claimed the Court should annul the Commission decision contained in its letter of 2 February $1995,{ }^{118}$ while the Commission contended that the Court should dismiss the

${ }^{109}$ para. 11, n. 106 above.

110 para. 13, n. 106 above

111 para. 14, n. 106 above.

112 An applicant, according to the Code of Conduct's third section entitled "Processing of confirmatory applications", had the right to apply for a refusal to be reconsidered - a confirmatory application - within one month.

${ }_{113}$ para. 17, n. 106 above.

114 para. 20, n. 106 above.

115 para. 20, n. 106 above.

116 para. 20, n. 106 above.

117 para. 22 , n. 106 above.

118 para. 26, n. 106 above. 
application. ${ }^{119}$ The applicant relied on two pleas in support of its application. The first was based on breach of the Code of Conduct and infringement of Decision 94/90. The second was based on infringement of Article 190 EC (now Article 253) EC. ${ }^{120}$

The applicant first alleged that the Commission had infringed Decision $94 / 90$ by mistakenly invoking the exceptions in the Code of Conduct as adopted by Article 1 of the Decision. ${ }^{121}$ The applicant said Decision 94/90 and the Code of Conduct were legally binding on the Commission and conferred on persons in the Community a right of access to documents "to the widest extent possible". ${ }^{122}$ The Commission said Decision 94/90 and the Code of Conduct gave rise to "no absolute or fundamental right of access to documents in favour of citizens".

The applicant said the Commission was not entitled to invoke the exceptions in a general way but must establish by reference to the particularities of each case the "imperative reasons" for which the conditions for application of an exception were fulfilled. ${ }^{123}$ The Commission contended that, when it invoked a mandatory exception, it "had no need to engage in an exercise of balancing its interests against those of the person who has requested access to the documents". When a discretionary exception was invoked, the balancing of interests was undertaken. ${ }^{124}$

The applicant challenged the reference in the contested decision to the exception in favour of protection of the public interest (hereinafter the "public interest exception") and to that in favour of protection of the institution's interest in the

\footnotetext{
119 paras. 27 and 28, n. 106 above.

120 para. 29 , n. 106 above. See also n. 71 above.

121 para. 31, n. 106 above.

${ }^{122}$ para. 32, n. 106 above.

123 para. 36, n. 106 above.

124 para. 38, n. 106 above.
} 
confidentiality of its proceedings (hereinafter the "confidentiality exception"). ${ }^{125}$ First, the applicant argued that the Commission had interpreted the public interest exception too widely by refusing access to all documents relating to infringement proceedings as to their content, and to the specific circumstances of the particular investigation. ${ }^{126}$ The applicant also submitted that the Commission had to demonstrate, by reference to imperative reasons, why disclosure would undermine the protection of the public interest. ${ }^{127}$ Second, the applicant said the invocation of the confidentiality exception failed to fulfill the conditions required in the Code of Conduct. The applicant alleged that the Commission merely claimed that the documents sought concerned its internal deliberations, without balancing its interests against the applicant's right of access. The applicant emphasised that the Commission had failed to provide the necessary "imperative reasons", contrary to the requirements of the case law. ${ }^{128}$

The Commission denied such accusations. As to the public interest exception, it stressed that the exemption was one of the mandatory exceptions. ${ }^{129}$ It contended it was clear from the Code of Conduct's wording that once there was a danger that disclosure of particular documents would undermine the public interest, the application of the exception was obligatory. ${ }^{130}$ With regard to the confidentiality exception, the Commission argued that the use of the word "may" in the category showed that it had a discretion. It said, as the invoked confidentiality related to the examination and investigation of infringements, rather than internal procedures, it was fair to say that the confidentiality in question involved exactly the same elements

125 para. 39 , n. 106 above.

126 para. 40 , n. 106 above.

127 para. 40, n. 106 above.

128 para. 41, n. 106 above.

129 para. 43, n. 106 above.

130 para. 44, n. 106 above. 
as those of the public interest exception. Thus, it said its "entitlement to invoke the former exception is precisely the same as its entitlement to rely upon the latter". ${ }^{131}$

\subsubsection{Held}

First, the CFI considered that the letter from the Commission's Secretary General, dated 2 February 1995, contained the decision challenged in the present case. ${ }^{132}$ As to the invocation of the exceptions in the Code of Conduct, the Court said where a general principle was established and exceptions to that principle were laid down, the exceptions should be construed and applied strictly, in a manner which did not defeat the application of the general rule. ${ }^{133}$ The CFI considered that the distinction between these two categories of exception in the Code of Conduct was explained by the nature of the interest which the categories sought respectively to protect. The Court said that:

The first category, comprising the "mandatory exceptions", effectively protects the interest of third parties or of the general public in cases where disclosure of particular documents by the institution concerned would risk causing harm to persons who could legitimately refuse access to the documents if held in their own possession. On the other hand, in the second category, relating to the internal deliberations of the institution, it is the interest of the institution alone which is at stake. ${ }^{134}$

The Court said the Commission was entitled to invoke jointly an exception within the

131 para. 49, n. 106 above.

132 para. 21, n. 106 above.

133 para. 56, n. 106 above.

134 para. 60 , n. 106 above. 
first category and one within the second to refuse a request. ${ }^{135}$ However, the Court stressed that the Commission should not "confine itself to invoking the possible opening of an infringement procedure as justification, under the heading of protecting the public interest, for refusing access to the entirety of the documents identified in a request made by a citizen". ${ }^{136}$ The Court said the Commission had been required to indicate the reasons for which it considered that the documents detailed in the request which it received were about the possible opening of an infringement procedure. ${ }^{137}$ The Court said the contested decision, however, confined its reasons for refusing that request solely to the confidentiality exception, as had been indicated in the letter from DG XVI, as there was no reference to the public interest exception in the texts. ${ }^{138}$

The Court stated that it did not appear from the DG XVI's letter or the contested decision that the Commission had undertaken a genuine balancing of the interests involved as required by the Code of Conduct, because both the decision and the letter confined themselves to mention the confidentiality exception and made no mention of balancing of the interests involved. ${ }^{139}$ Thirdly, the Court stated that the contested decision had referred expressly to the letter from DG XVI, which made no reference to the public interest exception. ${ }^{140}$ Thus, the contested decision did not meet the requirement to state reasons in former Article $190 \mathrm{EC}$ and must be annulled. ${ }^{141}$

The Court stated that the Commission had given no indication of its reasons for considering that the documents covered by the request to DG XI were "all related to

\footnotetext{
135 para. 61, n. 106 above.

136 para. 64, n. 106 above.

137 para. 64, n. 106 above.

138 paras. 68 and 69, n. 106 above.

139 para. 70, n. 106 above.

140 para. 71, n. 106 above.

141 para. 72, n. 106 above.
} 
a possible infringement proceeding". ${ }^{142}$ Also, in its letter, DG XI had not indicated either the reasons for which the requested documents were in its view all covered by the public interest exception. ${ }^{143}$ Thus, as the Commission refrained from indicating that all the documents requested from DG XI were covered by the public interest exception and relied on the confidentiality exception, the applicant could believe that part of the documents held by DG XI were refused on the basis that they were covered by the confidentiality exception alone. The Court stated that "[n]either the contested decision nor the letter from DG XI enabled the applicant and, therefore, the Court to ascertain whether the Commission had fulfilled its obligation to undertake a genuine balancing of the interests involved as required by the Code of Conduct". ${ }^{144}$

The Court stated that, in so far as the contested decision dealt with the request made by the applicant to DG XI, it again failed to meet the requirements to state reasons which were laid down in former Article $190 \mathrm{EC}$ and must be annulled. ${ }^{145}$ The Court concluded that the contested decision must be annulled. ${ }^{146}$

\subsubsection{Comment}

In Carvel, the CFI set limits to the operation of the second category of discretionary exception by introducing the balancing test. As the Council's letters to the applicants indicated it had considered that it was obliged to refuse the request in question, the CFI annulled the decisions concerned. In $W W F$, in his letter to the applicant, the

142 para. 74 , n. 106 above.

143 para. 75 , n. 106 above.

144 para. 76, n. 106 above.

145 para. 77, n. 106 above.

146 para. 78, n. 106 above. 
Commission's Secretary General applied different terms, stressing that " $\mathrm{t}] \mathrm{he}$ fundamental principle guiding the consideration of each request is that the public will have the widest possible access to documents held by the Commission", but this empty statement did not lead the Court to uphold the refusal. It was rather because the Commission's invocation of the two categories of mandatory and discretionary exceptions was found inappropriate.

The applicant argued that the Commission was not entitled to invoke the exceptions in a general way, without setting out the basis for their application in the particular circumstances. As to the public interest exception, the WWF said the Commission had read this exception too widely, and it did not refer to any imperative reasons to demonstrate why the disclosure would undermine protection of the public interest. As to the confidentiality exception, the applicant said the Commission neither balanced relevant interests nor put forward any imperative reasons in the refusal.

The Commission emphasised the nature of the mandatory exception before attempting to extend the scope of this public interest exception, in order to eliminate the distinction between the public interest and confidentiality exceptions. The Commission contended that when relying on a mandatory exception, it had no need to balance its interests against those of the person who requested access to the documents. Secondly, it said that, as the confidentiality at issue concerned the investigation of infringements, rather than internal procedures, exactly the same elements were at play as those raised by the public interest exception. The Commission also argued that the use of the word "may" in the exception relating to internal proceedings had shown that in this instance it had a discretion. Thus, it considered that its "entitlement to invoke the former exception is precisely the same 
as its entitlement to rely upon the latter". This highly contentious statement indicated that the Commission had misunderstood the term "discretion", because it believed that it was allowed under the second category of discretionary exception to refuse a request on the basis of considerations applicable to the first category of mandatory exceptions. Although the Commission did not expressly reveal whether it was invoking the former or latter exception, it apparently planned to apply the former as it was mandatory. If the Commission was allowed to do so, it successfully eliminated the distinction between the two categories of mandatory and discretionary exceptions.

The Court disagreed with the Commission and stated that the exceptions should be strictly applied. The judgment was mainly based on the following grounds:

1. The Commission should establish why it considered that the documents sought related to the possible opening of an infringement procedure.

2. The contested decision confined its reasons for refusing that request solely to the confidentiality exception, as there was no reference to the public interest exception in the decision or the letter from DG XVI.

3. The Commission did not undertake a genuine balancing of the interests involved as required by the confidentiality exception.

The judgment revealed that the Court, first, considered that the Commission must establish why the requested documents related to the possible opening of an investigation. In other words, the Commission must explain why the documents related to the protection of the public interest if that was what it was relying on. Second, the Court concluded that the contested decision had confined its reasons for refusing that request solely to the confidentiality exception. It bears noting that the 
scope of this exception in the Court's view was much narrower than that of the Commission. Finally, as the Commission did not undertake a genuine balancing of the interests involved, the contested decision was annulled.

As regards whether freedom of information constituted a fundamental right, the applicant said Decision 94/90 and the Code of Conduct conferred on persons in the EC a right of access to documents "to the widest extent possible", but the Commission said the texts gave rise to "no absolute or fundamental right of access to documents in favour of citizens". As in Carvel, the CFI avoided making a statement about this issue in $W W F$. However, this does not mean that the CFI made no effort to provide citizens in the EU with more FOI protection. In fact, the CFI elevated protection of this freedom to a level similar to that of a fundamental right, when it elaborated on the methods of stricter invocation of the two categories of exemption.

\subsection{The Interporc I and Carlsen cases}

Exceptions set out in the fourth section, first subsection of the Code of Conduct, to which Article 4(1) of Council Decision 93/731 corresponded, comprised the "mandatory exceptions", and protected the "interest of third parties or of the general public", according to the $W W F$ judgment. The CFI also said, as to the fourth section, second subsection of the Code of Conduct, which Article 4(2) of Decision 93/731 adopted, "it is the interest of the institution alone which is at stake". This distinction seemed to be clear: the first category contained mandatory exceptions which mainly 
addressed the interest of the public, while the second category established the discretionary exception, securing the interests of the Commission or Council.

The distinction was, however, shown to be hazy. It is also doubtful whether the CFI was right in $W W F$ when it stated that the interest protected by the second category of discretionary exception solely related to the Commission. Various types of documents, for instance, those concerning EC legislation and court proceedings, can be discussed at the meetings of the Commission and Council. As draft legislation and court proceedings can have a strong impact on citizens of the Union, the two institutions could, first, apply the first category of mandatory exceptions to deny a request for access to information relating to legislation and court proceedings. Such a refusal could be made on the basis that release of the information could damage one of the interests listed in the first category of mandatory exceptions, in particular, the public interest. Second, the institutions could choose to apply the second category of discretionary exception in a refusal on the ground that disclosure could jeopardise the confidentiality of their proceedings. They could also concurrently apply the two provisions in a refusal, the third approach available when refusing a request.

The CFI might have imperfectly drawn the line between the two categories of exemption, but the Court should be praised for attempting to distinguish the two since the Court drew the distinction to improve FOI protection and to remedy the flawed rules establishing the exceptions. These rules provided the two institutions with excessive discretion, i.e. the three approaches noted above, when making refusals. A literal interpretation of the two categories of exemption would suggest that there was only a vague dividing line between them, and Carvel and WWF revealed that the two institutions and the CFI interpreted the distinction in a very different manner. The institutions, which attempted to take advantage of the 
indistinct line, failed to indicate expressly which of the two provisions they were relying on in their refusals. It was the applicants and the CFI that channelled the disputes in Carvel to the second category of discretionary exception and in $W W F$ to the first category of mandatory exceptions.

In Carvel, the CFI stated that "the Council must, when exercising its discretion under Article 4(2) [of Council Decision 93/731], genuinely balance the interest of citizens in gaining access to its documents against any interest of its own in maintaining the confidentiality of its deliberations". The balancing of interest obligation placed on the Council was a difficult one. In $W W F$, what the applicant requested were documents relating to the Commission's examination of an Irish government construction project. The Commission could have chosen to apply the discretionary exception to refuse the request, but it did not do so. The Carvel judgment might have had an influence on the Commission's strategy in the WWF case. The Commission tried to invoke both of the provisions, which was exactly the third of the approaches noted above. However, this approach was unsuccessful, as the CFI said the contested decision was based solely on the confidentiality exception and no balancing of relevant interests was undertaken. To put it differently, the Court held that the Commission was not entitled to apply the two provisions jointly without realising there was a distinction between them.

These two cases reveal that the Court considered the two categories to be distinct, but the Council and Commission read the categories as overlapping and tried to avoid the balancing test. The two categories provided the institutions with disproportionate power to refuse a request. Without judicial scrutiny over the institutions, there would have been no balancing of interests as the public would have had no legal means to secure its freedom of information. The role of the Court was 
very important as it established the duty to balance the institutions' interests in confidentiality with that of the citizen in seeking disclosure of information. The following subsections examine two judgments delivered by the CFI in 1998, to see whether the Court was prepared to elaborate further on the scope of the exceptions or alter its previous position.

\subsubsection{The 1998 Interporc / case $\mathrm{c}^{147}$}

\subsubsection{Facts and ruling}

Under the Community's "Hilton quota", certain quantities of high-quality beef, "Hilton beef' from Argentina, could be imported into the Community free of levies, but a certificate of authenticity from the Argentine authorities was required. ${ }^{148}$ Germany sought post-clearance recovery of import duty from the applicant, Interporc Im- und Export $\mathrm{GmbH}$, a German company, after this firm presented falsified certificates of authenticity to the German authorities. ${ }^{149}$ The applicant requested remission of that duty and claimed that it presented the documents "in good faith and that certain deficiencies in the control procedure were attributable to the competent Argentine authorities and to the Commission". ${ }^{150}$ The Commission decided on 26 January 1996 that the applicant's request for the remission was "not justified". 151 The company then requested access to 10 categories of document relating to the control procedures for imports of Hilton beef and to the inquiries which gave rise to

\footnotetext{
147 Case T-124/96, Interporc Im- und Export GmbH v. Commission [1998] ECR II-231.

148 para. 9 , n. 147 above.

149 para. 11, n. 147 above.

150 para. 11 , n. 147 above.

151 para. 12 , n. 147 above.
} 
Germany's decision to effect the recovery of import duty. ${ }^{152}$

The Commission refused this request and the firm then made a confirmatory application. ${ }^{153}$ The applicant and two other German firms later sought the annulment of the Commission's decision of 26 January 1996, which was the Primex case. ${ }^{154}$ By letter of 29 May 1996, the institution rejected the confirmatory application. In this letter, which later became the contested decision in this Interporc $I$ case, the Commission said the requested documents concerned the Commission's 26 January 1996 decision, which had become the subject-matter of an application for annulment in the Primex case. ${ }^{155}$ It added that "[c]onsequently, the exception for protection of the public interest (court proceedings) is applicable". ${ }^{156}$

The applicant brought this action, seeking annulment of the contested decision. ${ }^{157}$ This firm alleged infringement of the Code of Conduct, Decision 94/90, and Article 190 EC (now Article 253 EC). ${ }^{158}$ It said the Commission should weigh the interests which the exception in question was intended to protect against the overall aim of the Code of Conduct and establish for each document the "imperative reasons" justifying application of the exception. ${ }^{159}$ It added that "[t]he Commission is wrong to consider, relying on the exception for protection of the public interest (court proceedings), that it is empowered to refuse access to any document relating to

152 para. 13, n. 147 above. The documents include, for instance, (1) the declarations of the Member States of quantities of Hilton Beef imported from Argentina between 1985 and 1992, (2) the declarations of the Argentine authorities of quantities of Hilton Beef exported to the Community in the same period, (3) the Commission's internal records drawn up on the basis of those declarations, and (4) the documents relating to the opening of the Hilton quota.

153 para. 16, n. 147 above.

154 para. 17, n. 147 above. See Case T-50/96, Primex Produkte Import-Export and Others $v$. Commission [1998] ECR II-3773.

155 para. 18 , n. 147 above.

156 para. 18, n. 147 above.

157 paras. 20 and 23, n. 147 above.

158 paras. 25 and 26, n. 147 above.

159 para. 30, n. 147 above. In this regard, the applicant relied on the order of the ECJ in the 1990 Zwartveld case, in particular, paras 11 and 12 of the judgment. Case C-2/88, Zwartveld and others [1990] ECR I-3365. 
a decision which is the subject of an action for annulment". ${ }^{160}$ In response, the Commission said the public interest exception relating to court proceedings authorised it not to make available to the public all documents relating to pending proceedings. For that exception to be applicable, it considered it was enough that the documents requested concerned the pending proceedings and related to their subject-matter. ${ }^{161}$

Secondly, as to possible infringement of former Article 190 EC, the applicant said the contested decision did not meet the requirements of that provision. ${ }^{162}$ According to the applicant, first, "the contested decision does not reveal whether the special features of the case in issue were analysed. In addition, the Commission did not specify the reasons for which it considers that the exception for protection of the public interest (court proceedings) is applicable". ${ }^{163}$ It added that "the Commission failed, in breach of its obligations, to state for each document the imperative reasons' for which disclosure would jeopardise protection of the public interest". ${ }^{164}$ The Commission denied this accusation, saying it was not obliged to prove, for each and every document, that disclosure could damage the public interest. ${ }^{165}$

The Court examined the exceptions in the Code of Conduct, especially the distinction between the two categories of mandatory and discretionary exceptions, ${ }^{166}$ stating that a Commission decision concerning the first category of mandatory exceptions, "must state the reasons on which it is based, in accordance with Article

\footnotetext{
${ }^{160}$ para. 31, n. 147 above.

161 para. 36, n. 147 above.

162 para. 41, n. 147 above.

163 para. 42 , n. 147 above.

164 para. 43, n. 147 above.

165 para. 45, n. 147 above.

166 paras. $49,50,51$, and 52, n. 147 above.
} 
190 of the Treaty". ${ }^{167}$ The Court said it had consistently held that "the reasoning required by that provision must show clearly and unequivocally the reasoning of the Community authority which adopted the contested measure so as to enable the persons concerned to ascertain the reasons for the measure in order to protect their rights, and the Court to exercise its power of review". ${ }^{168}$ The Court, therefore, said the statement of the reasons for a refusal must contain the specific reasons for which the Commission considered that disclosure of the documents requested was precluded by one of the exceptions in the first category. ${ }^{169}$

The Court stated that "however, the contested decision contains only the conclusion that the exception for protection of the public interest (court proceedings) is applicable. It provides no explanation, even for categories of documents, from which it might be ascertained whether all the documents requested ... indeed fall within the scope of the exception relied upon". ${ }^{170}$ The Court, therefore, decided that the contested decision must be annulled. ${ }^{171}$

\subsubsection{Comment}

We focus on why the Commission would invoke the first rather than the second category of exception in its refusal. The two categories of exception, as we have seen, provided the Commission and Council with three approaches to refuse requests. In this case, the documents sought obviously related to the second category, because what the applicant had requested were the Commission's control procedures for imports of Hilton beef, including the institution's internal records drawn up on the

167 para. 53 , n. 147 above.

168 para. 53, n. 147 above.

169 para. 54, n. 147 above.

170 para. 55 , n. 147 above.

171 para. 57, n. 147 above. 
basis of those declarations, and the documents relating to the opening of the Hilton quota. It would not be surprising if the Commission had resorted to the category of discretionary exception, arguing that the refusal was aimed to secure confidentiality of the Commission's proceedings.

However, in relation to the discretionary exception, the CFI had placed the obligation to balance relevant interests on the Council and Commission in Carvel and $W W F$. This might explain why the Commission chose to apply the first category rather than the second. The Commission stressed that the public interest exception relating to court proceedings authorised it not to make available to the public all documents relating to pending proceedings. However, if the applicant and the two other German companies had not brought the Primex case before the Court, it would be fair to predict that the Commission would have resorted to the second category.

As the Commission invoked the public interest exception, the scope of the first category of mandatory exceptions was a major issue in this case. The refusal was based on the reason presented in the contested decision, namely, that the 10 categories of document related to an application for annulment. Thus, the Commission relied on "the exception for protection of the public interest (court proceedings)". Both this statement and the Commission's argument before the Court seemed to be correct because the first category of exceptions was indeed mandatory. The Court agreed that court proceedings closely related to the public interest, but it held that this ground alone was insufficient justification for the refusal since there should be control over the operation of even the mandatory exceptions. In other words, this provision did not entitle the Commission to refuse the request without providing further reasoning.

What reasons should be presented to support such a refusal? The CFI accepted 
the applicant's view in relation to former Article 190 EC. The CFI said a Commission decision concerning the first category "must state the reasons on which it is based, in accordance with Article 190 of the Treaty". The Court stressed that a refusal "must contain the specific reasons for which the Commission considered that disclosure of the documents requested was precluded by one of the exceptions provided for in the first category of exceptions". The Commission must elaborate why the disclosure could jeopardise one of the first-category exceptions. This statement indicated that, as with the invocation of the second category of exemption, the first category should also operate within strict limits, even though it was a mandatory provision. The contested decision was annulled as the Commission had not met this requirement.

The Court should be praised for laying down such clear obligations on the institution to improve FOI protection. Its approach was very different from the literal interpretation of the first category apparently preferred by the Commission.

\subsubsection{The Carlsen case ${ }^{172}$}

\subsubsection{Facts and ruling}

On an examination in proceedings for interim relief, Hanne Norup Carlsen and nine other applicants made a request to the Council for "access to opinions of legal services of the Community institutions concerning particular draft legislation", information held by the Council. ${ }^{173}$ The Council refused the request on the basis that

172 Case T-610/97, Carlsen and others v. Council [1998] ECR II-485.

173 para. 5, n. 172 above. 
the "disclosure ... could be detrimental to the public interest both in "the maintenance of legal certainty and the stability of Community law', and in 'the Council's being able to obtain independent legal advice'", ${ }^{174}$

The CFI said the statement of reasons required by Article 190 EC (now Article 253 EC) "must show clearly and unequivocally the reasoning of the institution which enacted the measure so as to inform the persons concerned of the justification for the measure adopted and to enable the Court to exercise its powers of review". It stated that the refusal concerned did not "appear to be in breach of the Code of Conduct ... or of Decision 93/731" (emphasis added), ${ }^{175}$ because the reasons presented by the Council "must be considered to be sufficient in the context of an application for interim measures". ${ }^{176}$ It added that, "the absence of a reference, in the statement of reasons, to the specific effects of releasing documents having such a content does not, taken alone, render the statement of reasons inadequate". 177

The CFI stated the documents sought were "merely working instruments", and disclosure of them could "give rise to uncertainty with regard to the legality of Community measures and have a negative effect on the stability of the Community legal order and the proper functioning of the institutions, which are matters of public matters". It said "those interests are not expressly referred to in the list of exceptions provided for in the Code of Conduct and Decision 93/731", ${ }^{178}$ but "it is the protection of the public interest in general which may justify refusal to grant access to documents, and accordingly it would not be right to limit the scope of the concept

\footnotetext{
${ }_{174}$ para. 4, n. 172 above.

175 para. 5, n. 172 above.

176 para. 4 , n. 172 above.

177 para. 4, n. 172 above.

${ }_{178}$ para. 5 , n. 172 above.
} 
of the public interest by reducing it to the five cases set out in [the] brackets". ${ }^{179}$

\subsubsection{Comment}

The information sought in this case comprised "opinions of legal services of the Community institutions concerning particular draft legislation", a category not among the five types of information set out in the bracket contained within the public interest provision. ${ }^{180}$ The Council, however, said the request should be refused on the ground that the "disclosure ... could be detrimental to the public interest both in 'the maintenance of legal certainty and the stability of Community law', and in 'the Council's being able to obtain independent legal advice"”.

As in Interporc I, the CFI stressed that reasons should be given for the refusal, but it apparently lowered the obligation put on the Commission in the present case. In Interporc I, the CFI said the Commission must detail the reasons why disclosure of each document sought could bring into play one of the exceptions in the first category, though it was a mandatory provision. The Council indeed presented two reasons for the refusal in Carlsen. However, prior to its refusal, the institution had apparently failed to establish why release of the specific information requested could damage "the maintenance of legal certainty and the stability of Community law" and "the Council's being able to obtain independent legal advice". Nonetheless, the Court held that reference to the two reasons "must be considered to be sufficient", leaving a number of questions unanswered.

\footnotetext{
179 para. 5, n. 172 above.

180 The five categories of information concerned public security, international relations, and monetary stability, as well as court proceedings, inspections and investigations.
} 


\section{A. Legal certainty}

As regards the term "legal certainty" - sometimes referred to as "legal security" (sécurité juridique, in French), it is one of the general principles recognised by the Community Court. ${ }^{181}$ It is a wide reaching concept that cannot be easily explained in a few words, though predictability is its core aspect. The most important sub-concepts of legal certainty are non-retroactivity, the protection of vested rights, and legitimate expectations. ${ }^{182}$ Nevertheless, the Council failed to elaborate on which of the elements of legal certainty could be damaged by disclosure in this case.

The CFI said in its judgment that the documents sought were "merely working instruments", adding that disclosure of them could "give rise to uncertainty with regard to the legality of Community measures and have a negative effect on the stability of the Community legal order and the proper functioning of the institutions". This view corresponded to the Council's claim, but the Court also failed to check whether disclosure of the information sought could jeoparidse any of the components of legal certainty noted above. In other words, the Court failed to consider whether the Council had established why the information sought could have a negative effect on the stability of the EC legal order.

It is possible that there could be a difference between the legal advice offered by the legal services and legislation later adopted by the institutions, and that this might lead to adverse comments on the legislation or even criticism of the legal services or the institutions. This is apparently a result that the Council may seek to avoid. The Council can thus obtain legal opinions and discuss them internally under the name of protecting its ability to receive "independent legal advice". Reliance on this claim

181 Hartley, n. 105 above, at 146.

182 Hartley, n. 105 above, at 147. 
helps the Council and its legal service escape scrutiny by the European public. The statement made by the Council arguably related more to its fear of democratic scrutiny than a desire to protect legal certainty. Without further development, both the Council and the Court's opinions seem insufficient to justify the refusal.

\section{B. Nature of legal advice}

The Council said it refused the request on, inter alia, the ground that disclosure of the information sought could be detrimental to the public interest in "the Council's being able to obtain independent legal advice". The Court stated that "it would not be right to limit the scope of the concept of the public interest by reducing it to the five cases set out in [the] brackets". However, what the Court did not say, at least not explicitly, was where the proper limit was, and whether all legal advice prepared by the legal services should be understood as included.

These views can be considered from the following perspectives. The exceptions set out in the Code of Conduct and Council Decision 93/731 were extensive. The Court should be very careful when extending the already broad scope of the exceptions. This extension would set an additional limit to the freedom of information offered by the Code of Conduct and the corresponding Council and Commission Decisions. As Professor Deirdre Curtin has said, "[ $\mathrm{t}]$ he very wide interpretation of public interest accepted by the CFI in Carlsen gives the Courts considerable margin in fleshing out its scope in practice, and does not seem to take account of the fact that exceptions to general principles must be construed narrowly". ${ }^{183}$

183 D. Curtin, 'Citizens' Fundamental Right of Access to EU Information: an Evolving Digital Passepartout?' (2000) 37 Common Market Law Review 34. 
We should also examine the main issue of this case - the nature of the information sought, i.e. opinions prepared by the legal services of the Council and Commission. The CFI did not address this issue in its judgment, but such analysis will help determine whether there is "independent legal advice", and whether the Council should be allowed to obtain this kind of opinion without being scrutinised by the public. To analyse the nature of the legal advice requires consideration of the role of the legal services within the two institutions. There are a number of specialised services within the Council and Commission, including legal services. The legal services provide the institutions with legal advice, which can be mainly divided into opinions on draft legislation, international negotiations, and those relating to court proceedings. ${ }^{184}$ Legal advice is privileged and thus has a unique nature because it is absolutely necessary to ensure that legal professionals are able to offer legal advice without being subject to undue influence.

The Court rightly held that legal advice fell within the scope of the public interest exception in the Code of Conduct. It bears noting that it is the ability of the Council to obtain independent legal advice that should be protected under the public interest exception. To express the wish to secure this ability should not have been regarded as a statement of sufficient reasons required by former Article 190 EC. What the CFI should have examined was whether the Council had established why release of the legal opinions at issue would prevent it from obtaining independent legal advice. However, the CFI accepted that merely to indicate the wish was

\footnotetext{
184 The legal service under the Commission "provides comprehensive in-house assistance to the Commission and all its departments. Its resources have to be deployed to cover all Commission activities and areas of responsibility. In each area, it must be able to assist the Commission in its functions of drafting legislation and conducting international negotiations". The legal service alone can act as agent of the Commission in legal proceedings before the Community Court, the EFTA Court, and the WTO panels. A detailed description of the role of this legal service is available at its website: http://www.europa.eu.int/comm/dgs/legal_service/index_en.htm. The Council's legal service has similar function.
} 
sufficient. Therefore, the Council and Commission might consider that the public interest exception entitles them to refuse access to legal opinions on a systematic basis.

\section{Application of the Code of Conduct}

The CFI's application of the Code of Conduct in this case deserves specific attention. It should be noted that, in the 1996 Netherlands judgment, the ECJ considered the Code of Conduct to be a non-binding measure. The ECJ said in the judgment that "the Code is an act which is the expression of purely voluntary coordination and is therefore not intended in itself to have legal effects". However, the CFI applied the Code of Conduct in this case as if it were legally binding. For instance, the Court used the terms "in breach of the Code of Conduct ... or of Decision 93/731", suggesting that both the Code of Conduct and Decision 93/731 were of a normative quality.

\subsection{The van der Wal case}

Documents connected with court proceedings are one category among the five set out in the bracket contained within the Code of Conduct's public interest exception. This court proceedings exception is enshrined in the provision to secure the right to a fair hearing, a fundamental right assured by Article 6 of the European Convention on 
Human Rights and in constitutional traditions of most democracies in the world. ${ }^{185}$

What could, however, be controversial in relation to FOI protection is the scope of the court proceedings exception. The right of EU citizens to a fair hearing by an independent tribunal could be jeopardised if the scope is narrowly drawn. However, the EU institutions could take advantage of this exception to avoid democratic scrutiny if the scope is unduly extensive. In the analysis of the van der Wal case, we examine the efforts by the $\mathrm{CFI}^{186}$ and $\mathrm{ECJ}^{187}$ to limit the invocation of this exception.

\subsubsection{Facts}

Mr. Gerard van der Wal, a Belgian lawyer, dealt with EC competition law cases. He requested copies of three letters sent by the Commission's Directorate-General for Competition to three courts in Düsseldorf, St Brieuc, and Paris, under Notice 93/C $39 / 05$ on cooperation between national courts and the Commission in applying Articles 85 and 86 EC (now Articles 81 and 82 EC). ${ }^{188}$ The Director-General of DG IV (Competition) refused his request on the ground that disclosure of the letters

\footnotetext{
${ }^{185}$ Article 6 ECHR provides that:

In the determination of his civil rights and obligations or of any criminal charge against him, everyone is entitled to a fair and public hearing within a reasonable time by an independent and impartial tribunal established by law. Judgment shall be pronounced publicly but the press and public may be excluded from all or part of the trial in the interests of morals, public order or national security in a democratic society, where the interests of juveniles or the protection of the private life of the parties so require, or to the extent strictly necessary in the opinion of the court in special circumstances where publicity would prejudice the interests of justice.

${ }^{186}$ Case T-83/96, Gerard van der Wal v. Commission [1998] ECR II-545.

187 Joined cases C-174/98 and C-189/98, Kingdom of the Netherlands and Gerard van der Wal v. Commission [2000] ECR I-0001.
}

${ }^{188}$ [1993] OJ C39/ 6. 
would be detrimental to "the protection of the public interest (court proceedings)". ${ }^{189}$ The applicant made a confirmatory application to the Secretariat-General but by letter dated 29 March 1996, the Secretary-General confirmed DG IV's refusal as disclosure "could undermine the protection of the public interest and, more specifically, the sound administration of justice". ${ }^{190}$ The applicant then brought this action before the CFI. He claimed that the CFI should annul the decision in the March 1996 letter, while the Commission contended that the Court should dismiss the application. ${ }^{191}$

The applicant raised two pleas, alleging infringement of Commission Decision 94/90 and Article 190 EC (now Article 253 EC). ${ }^{192}$ In the first plea, he said the court proceedings exception in the Code of Conduct could not be relied on in this case because it applied only to proceedings to which the Commission is a party. ${ }^{193}$ If the Court disagreed on this view, he alternatively submitted that "disclosure of the documents in issue does not undermine the cooperation between the Commission and national courts or adversely affect the public interest". ${ }^{194} \mathrm{He}$ said that "the information which might be provided by the Commission in the context of cooperation with national courts is not in any way confidential". ${ }^{195}$ The Commission, first, rejected the view that the court proceedings exception applied only to the proceedings to which the Commission was a party. ${ }^{196}$ It stressed that " $[\mathrm{t}]$ he rule set out in the Code of Conduct is broad enough to include Commission letters drafted in

189 para. 12, n. 186 above.

190 para. 15, n. 186 above.

191 paras. 22 and 23, n. 186 above.

192 n. 71 above.

193 para. 25, n. 186 above.

194 para. 26, n. 186 above.

${ }_{195}$ para. 28, n. 186 above.

196 para. 34, n. 186 above. 
the context of cooperation with national courts". 197 Second, it said that "[d]isclosure of the replies given by the Commission in the context of the Notice could indeed undermine the protection of the public interest (court proceedings)". ${ }^{198}$ The Commission also said it "plays a secondary role vis-à-vis the national court" in the context of its cooperation with national courts, adding that its role "can be compared to that of an expert commissioned by a court to provide information or an opinion". 199

In his second plea alleging infringement of former Article $190 \mathrm{EC}$, the applicant said the statement of reasons given by the Commission was insufficient. ${ }^{200}$ However, the Commission said the refusal was based on sufficient grounds as its letters "clearly indicate the reasons for which the application for access was refused". 201

The CFI first addressed the plea that alleged infringement of Decision 94/90. It considered the extent to which the Commission was entitled to invoke the court proceedings exception to refuse the request. ${ }^{202}$ It said it had drawn inspiration from Article 6 ECHR and that "[t]he right of every person to a fair hearing by an independent tribunal means, inter alia, that both national and Community courts must be free to apply their own rules of procedure concerning the powers of the judge, the conduct of the proceedings in general and the confidentiality of the documents on the file in particular". ${ }^{203}$ It held that the court proceedings exception in Decision 94/90 was "designed to ensure respect for that fundamental right". ${ }^{204}$ Thus, the scope of that exception entitled the Commission to "rely on that exception

\footnotetext{
197 para. 34 , n. 186 above.

198 para. 36, n. 186 above.

199 para. 37 , n. 186 above.

200 para. 57, n. 186 above.

201 para. 61, n. 186 above.

202 para. 44 , n. 186 above.

203 para. 47, n. 186 above.

204 para. 48 , n. 186 above.
} 
even when it is not itself party to the court proceedings which, in the particular case, justify the protection of the public interest". ${ }^{205}$ Moreover, it stated that:

[A] distinction must be drawn between documents drafted by the Commission for the sole purposes of a particular court case, such as the letters in the present case, and other documents which exist independently of such proceedings. Application of the exception based on the protection of the public interest can be justified only in respect of the first category of documents." 206

The CFI declined to uphold the first plea because "[t]hose letters thus concerned points of law raised in the context of specific pending proceedings". ${ }^{207}$

As to the second plea alleging that the Commission's reasons were inadequate, the CFI did not accept this since "the Commission clearly indicated the grounds on which it had applied the exception based on the need to protect the public interest (court proceedings) in respect of the three replies requested, whilst taking account of the nature of the information contained therein". ${ }^{208}$ The applicant later appealed this decision to the ECJ.

\subsubsection{Held}

The ECJ, which did not dispute the CFI's view on the right to a fair hearing, set aside the CFI's judgment since not all the documents sought concerned Article 6 ECHR. ${ }^{209}$ The ECJ said documents supplied by the Commission to national courts could be

205 para. 49 , n. 186 above.

206 para. 50, n. 186 above.

${ }_{207}$ para. 52, n. 186 above.

208 para. 71, n. 186 above.

209 paras. $14-31$, n. 187 above. 
those "in which the Commission merely expresses an opinion of a general nature, independent of the data relating to the case pending before the national court". ${ }^{210}$ It said such documents "may also contain legal or economic analyses, drafted on the basis of data supplied by the national court". 211 The ECJ said that "[c]ompliance with national procedural rules is sufficiently safeguarded if the Commission ensures that disclosure of the documents does not constitute an infringement of national law". ${ }^{212}$ It annulled the refusal, stating that the Commission infringed Decision $94 / 90$ because it did not verify whether the documents requested constituted legal or economic analyses of the type noted above, and "if that were so, without ensuring that their disclosure was not contrary to national law". 213

\subsubsection{Comment}

The issue here is whether the three letters in question, which contained legal opinions provided by the Commission to three national courts, should have been made available to the public. The dispute mainly concerned three separate but interrelated issues that should be taken into account. First, we must consider the legal basis of the court proceedings exception. Second, the nature of the information obtained on the basis of cooperation between the Commission and national courts should also be analysed, to determine whether all the information offered by the Commission falls within the scope of the exception. Third, if the answer is positive, it is unnecessary to

\footnotetext{
${ }^{210}$ para. 24, n. 187 above.

211 para. 25, n. 187 above.

212 para. 28 , n. 187 above.

213 para. 33, n. 187 above.
} 
examine the character of the information sought by the applicant, as it should be excluded from openness despite its nature. Nonetheless, such an examination will be of great importance if only part of the information falls within the area that should not be made available to the public.

The applicant and the Commission's arguments indicated that they addressed the controversy in this case without carefully considering these three issues discussed further below. For instance, the applicant said before the CFI that "disclosure of the documents in issue does not undermine the cooperation between the Commission and national courts or adversely affect the public interest". The Commission said before the CFI that "[d]isclosure of the replies given by the Commission in the context of the Notice could indeed undermine the protection of the public interest (court proceedings)". These arguments show that both parties touched on the first two issues noted above, but they addressed them inadequately. The applicant simply assumed that the disclosure would not undermine the public interest, while the Commission held a contrary view, both failing to show a firm legal basis for their statements.

\subsubsection{Basis of the court proceedings exception}

The CFI considered the extent to which the court proceedings exception entitled the Commission to refuse the request. What the CFI did first was to elaborate on the legislative basis of the exception, i.e. the first of the three major issues above. It said the right of every person to a fair hearing by an independent tribunal means, inter alia, that both national and Community courts must be free to apply their own rules of procedure concerning the powers of the judge, the conduct of the proceedings in general and the confidentiality of the documents on the file in particular. The CFI 
said this exception was designed to better protect the right to fair hearing, which was quoted in the ECJ judgment, indicating that the ECJ agreed on this interpretation. ${ }^{214}$

\subsubsection{Information offered on basis of cooperation}

What should then be considered is whether all types of information offered by the Commission under the Notice fell within the scope of the court proceeding exception, the second of the three issues mentioned above. The CFI gave an answer to this question, which was that application of this exception could be justified only in respect of documents drafted by the Commission for the sole purposes of a particular case rather than those existing independently of such proceedings. The second category of documents mentioned by the CFI, namely those that exist independently of such proceedings, was of little controversy, because granting access could in no way undermine the right to a fair hearing. Nevertheless, we doubt whether the CFI adequately delimited the scope of the first category. The right to a fair hearing, in the CFI's words, means that both national and Community courts must be free to apply their own rules of procedure, but release of not all the documents drafted for a particular case would infringe the courts' right to apply freely its procedural rules. According to the Notice, national courts may ask the Commission and in particular its Directorate-General for Competition for "information of a procedural nature". National courts may also consult the Commission on points of law regarding the application of former Articles 85 and 86 EC. All the responses from the Commission are prepared for pending cases, but it is unlikely that disclosure of all the answers would jeopardise the right to a fair hearing.

\footnotetext{
${ }^{214}$ para. 7, n. 187 above.
} 


\subsubsection{Nature of the information at issue}

A serious point thus concerns the nature of the information sought by the applicant in this case. It was unlikely that disclosure of each of the opinions at issue would be detrimental to the national courts' freedom to apply procedural rules. This was, firstly, because, as the Commission stated before the CFI, the Commission only played a secondary role vis-à-vis the national courts. The national courts remained entitled to apply their own procedural rules. Secondly, where individuals decide to avoid judicial proceedings after accessing the legal opinions provided by the Commission, such a decision could in no way stop the national courts from freely applying their procedural laws. Finally, it is not the case that access to all the legal opinions from the Commission would jeopardise the right to a fair hearing. As Professor Deirdre Curtin said before the ECJ judgment that:

[B]ecause [the three letters] had been produced at the request of a national court for use in national court proceedings the fundamental right to a fair hearing in the view of the CFI took precedence over the citizens' right of access. I suggest that this is a very questionable approach and that it is not at all clear the "right to a fair hearing" could indeed be affected. ${ }^{215}$

As long as the disclosure of the content of the documents would not infringe the domestic procedural law in question, access to the information should not be denied. This was why the ECJ held that "[c]ompliance with national procedural rules is

\footnotetext{
${ }^{215}$ Professor Deirdre Curtin asked "whose right to a fair hearing was at stake by granting access to documents prepared by the Commission (on points of law and its customary practices) at the request of the national court". Therefore, she said in 2000 before the ECJ judgment that the reasoning of the CFI on this point was fundamentally flawed, and she suspected it might not be upheld on appeal to the ECJ. Curtin, n. 183 above, at 34. See also S. Peers, 'The European Court of Justice and the European Court of Human Rights: Comparative Approaches,' in E. Örücü (ed.), Judicial Comparativism in Human Rights Cases (London, The United Kingdom National Committee of Comparative Law, 2003), 124.
} 
sufficiently safeguarded if the Commission ensures that disclosure of the documents does not constitute an infringement of national law".

\subsubsection{Conclusion}

The Code of Conduct, Commission Decision 94/90, and Council Decision 93/731 were all intended to offer "widest possible access" to information. An overbroad scope for the court proceedings exception was presumably to undermine public scrutiny of the operation of the EU institutions. The CFI judgment as to the scope of this exception was dangerous, because it only considered the importance of the right to a fair hearing, without noticing that EU citizens were entitled to monitor the operation of the institutions, including cooperation between the Commission and national courts. Lack of freedom of information definitely has a negative impact on democratic scrutiny in the Union. For instance, citizens may lack the legal means to scrutinise the Commission if it provides national courts with incorrect legal analyses.

As to whether the information at issue fell within the scope of the court proceedings exception, which is the third major issue relating to the present case, the CFI gave a positive answer. However, the CFI came to the conclusion on the sole ground that the three letters "concerned points of law raised in the context of specific pending proceedings". This opinion was far from satisfactory because, as we have seen, information relating to pending cases is not necessarily detrimental to the right to a fair hearing. The ECJ stated that documents supplied by the Commission to national courts could be those that contain "an opinion of a general nature" or economic analyses. As such information did not undermine protection of the right to a fair hearing, the ECJ set aside the CFI judgment. 


\subsection{The 1998 Svenska Journalistförbundet case ${ }^{216}$}

Svenska Journalistförbundet, the Swedish Journalists' Union, deliberately tested Council Decision 93/731 against the wider Swedish FOI law after the Nordic country's accession to the EU on 1 January 1995. This action, of experimental nature, compelled the CFI to deliver clearer rules for invoking the two categories of mandatory and discretionary exceptions in the Code of Conduct and Decision 93/731.

\subsubsection{Facts}

Svenska Journalistförbundet made requests to the national Police Authority and Ministry of Justice in Sweden, seeking access to certain Council documents concerning the setting up of the European Police Office (hereinafter "Europol"), to "test the way in which the Swedish authorities applied Swedish citizens' right of access to information in respect of documents relating to European Union activities". ${ }^{217}$ The applicant was granted access to 18 of the 20 documents but was refused access by the Ministry of Justice to two documents mainly on the ground that they concerned the negotiating positions of the Dutch and German governments. ${ }^{218}$

The applicant then turned to the Council, requesting access to the same 20 documents under Decision 93/731, ${ }^{219}$ but the Council refused access to 18 of them

\footnotetext{
${ }^{216}$ Case T-174/95, Svenska Journalistförbundet v. Council [1998] ECR II-2289.

${ }_{217}$ para. 11, n. 216 above.

218 para. 11, n. 216 above.

219 para. 12, n. 216 above.
} 
because they were "subject to the principle of confidentiality as laid down in Article 4(1) of Decision 93/731". ${ }^{220}$ The applicant later submitted a confirmatory application. ${ }^{221}$ The Council replied by a letter dated 6 July 1995, in which it agreed to grant access only to two more documents. ${ }^{222}$ It said that "[i]n the Council's opinion access to those documents cannot be granted because their release could be harmful to the public interest (public security) and because they relate to the Council's proceedings, including the positions taken by the members of the Council, and are therefore covered by the duty of confidentiality". ${ }^{223}$

The applicant instituted this action before the CFI requesting the Court to annul the decision contained in the letter dated 6 July $1995,{ }^{224}$ while the Council supported by France and the UK requested the CFI to declare the application inadmissible. ${ }^{225}$

As to admissibility of this case, there were two key issues. First, the Council said the application was inadmissible mainly because it concerned "documents that the applicant had already received from the Swedish authorities. ...The applicant's interest is general and political in nature, its intention being to ensure that the Council gives proper effect to its own Code of Conduct and Decision 93/731". ${ }^{226}$ It said Article 173 EC (now Article 230 EC) did not "allow individual actions in the public interest, but only permits individuals to challenge acts which concern them in a way in which they do not concern other individuals", 227 adding that "the applicant

\footnotetext{
220 para. 13, n. 216 above.

221 para. 14, n. 216 above.

222 para. 17, n. 216 above.

223 para. 18 , n. 216 above.

224 para. 27 , n. 216 above.

225 para. 29, n. 216 above.

226 para. 53, n. 216 above.

227 para.54, n. 216 above. Former 173(2) EC provides that "[a]ny natural or legal person may, under the same conditions, institute proceedings against a decision addressed to that person or against a decision which, although in the form of a regulation or a decision addressed to another person, is of direct and individual concern to the former".
} 
cannot derive any benefit from obtaining access to documents which are already in its possession". 228 The applicant argued that "[a]ddressees must show that they have an interest in bringing their action but do not have to prove that they are individually concerned". ${ }^{229}$ It said its newspaper Tidningen Journalisten published articles "on specific subjects of general interest and on the functioning of public authorities and other matters concerning the way in which Swedish journalists can go about their job. It therefore has a direct interest in gaining access to Council documents". ${ }^{230}$

Second, France said in the absence of an express provision, Decision 93/731 was "not applicable to acts adopted on the basis of Title VI of the EU Treaty", which contained provisions on police and judicial cooperation in criminal matters. ${ }^{231}$ The applicant argued that Decision 93/731 “confirms that the Court has jurisdiction in cases concerning application of that decision, since it specifies that its provisions are applicable to any document held by the Council". ${ }^{232}$

As to the substantial aspect of this case, the applicant said the refusal infringed Article 4(1) of Decision 93/731. ${ }^{233}$ It argued that "the Council did not make a real assessment of the likely impact that granting access to the documents requested might have on public security in the European Union". ${ }^{234}$ It then precisely described all the documents sought which were in its possession, when arguing that "the public security exception was applied in an unlawful manner by the Council". ${ }^{235}$ The Council asserted that "it would not be in the interest of public security to allow those involved in illicit activities to obtain detailed knowledge of the structures and means

\footnotetext{
228 para. 55 , n. 216 above.

229 para. 57, n. 216 above.

230 para. 58, n. 216 above.

${ }^{231}$ para. 70 , n. 216 above.

${ }^{232}$ para. 73 , n. 216 above.

233 para. 88 , n. 216 above.

234 para. 90, n. 216 above.

235 para. 92 , n. 216 above.
} 
available to police cooperation in the European Union". ${ }^{236}$ The applicant disputed this and said it simply bore "no relation to the actual content of the documents in question". ${ }^{237}$ As to the legal basis for the refusal, the Council simply denied that it considered all the documents relating to Europol to be covered by the public security exception. It added that " $[\mathrm{t}]$ he fact that four documents were disclosed shows that a real assessment was carried out". ${ }^{238}$

The applicant also said the refusal infringed former Article $190 \mathrm{EC}$, stating that "the refusal, expressed in a single sentence, to grant access to 16 of the 20 documents does not satisfy the requirements of Article 190 of the EC Treaty or Article 7(3) of Decision 93/731". ${ }^{239}$ It was impossible for it "to assess whether the refusal should be challenged before the Court, for the Court to assess whether the Council had made proper use of the exceptions referred to above". 240 The Council argued that "[i]t would be excessive to require a specific statement of reasons for each of the technical choices made by the institution. If it were necessary to provide a very detailed statement of reasons in the case of negative responses to requests for access, the underlying objectives of Article 4(1) would be compromised". ${ }^{241}$

\subsubsection{Held}

Addressing its jurisdiction on this case, the CFI said that "Decision 93/731, in Articles 1(2) and 2(2), expressly provides that it is to apply to all Council documents.

\footnotetext{
${ }^{236}$ para. 93 , n. 216 above.

237 para. 93 , n. 216 above.

238 para. 94 , n. 216 above.

239 para. 104, n. 216 above.

240 para. 104 , n. 216 above.

241 para. 105 , n. 216 above.
} 
Decision 93/731 therefore applies irrespective of the contents of the documents requested". ${ }^{242}$ Secondly, as to the applicant's interest in seeking the annulment, the Court ruled that "[t]he applicant is the addressee of the contested decision and, as such, is not obliged to prove that the decision is of direct and individual concern to it. It needs only to prove that it has an interest in the annulment of the decision". ${ }^{243}$ The Court stressed that "a person who is refused access to a document or to part of a document has, by virtue of that very fact, established an interest in the annulment of the decision". ${ }^{244}$ The Court added that "the contested decision denied access to 16 of the 20 documents requested. The applicant has therefore proved an interest in the annulment of that decision". ${ }^{245}$ Thus, the Court held that the application was admissible.

As regards the substance of this case, the CFI concurrently examined the applicant's two pleas noted above, i.e. possible infringement of Article 4(1) of Decision 93/731 and that of Article 190 EC (now Article 253 EC). First, the CFI said the Council in the contested decision "indicated only that the disclosure of the 16 documents in question would prejudice the protection of the public interest (public security) and that the documents related to the proceedings of the Council, particularly the views expressed by members of the Council, and for that reason fell within the scope of the duty of confidentiality". ${ }^{246}$ The Court said that "[a]lthough the Council was at once invoking both the mandatory exception based upon the

\footnotetext{
${ }^{242}$ para. 81 , n. 216 above. Article 1(2) of Decision 93/731 provides that "'Council document' means any written text, whatever its medium, containing existing data and held by the Council, subject to Article 2(2)". Article 2(2) states that "[w] here the requested document was written by a natural or legal person, a Member State, another Community institution or body, or any other national or international body, the application must not be sent to the Council, but direct to the author".

${ }^{243}$ para. 64, n. 216 above.

${ }_{244}^{244}$ para. 67, n. 216 above.

${ }^{245}$ para. 68, n. 216 above.

${ }^{246}$ para. 118 , n. 216 above.
} 
protection of the public interest (public security) and also the discretionary exception based upon protection of the confidentiality of its proceedings, it did not specify whether it was invoking both exceptions in respect of all of the documents refused or whether it considered that some documents were covered by the first exception while others were covered by the second". ${ }^{247}$ What the Council did was to admit that it had not considered that all of the documents connected with Europol were covered by the exception relating to public security, without elaboration. ${ }^{248}$

The Court stated that a note prepared by the Council before the contested decision was made, indicated that it was concerned not with operational matters of Europol but "only with negotiations on the adoption of the Europol Convention". 249 As the note contained a brief summary of the documents and a preliminary assessment as to whether they could be released, which was communicated to the applicant in the court proceedings, the Court said the note clearly showed that "it was possible to give an indication of the reasons why certain documents could not be disclosed to the applicant without at the same time disclosing their contents". ${ }^{250}$

The Court went on to say that the terms of the contested decision did not permit the applicant and the Court to check whether the Council had complied with its duty to carry out a genuine balancing of the interests concerned as the application of Article 4(2) of Decision 93/731 required. ${ }^{251}$ The Court added that:

[T] he contested decision mentions only the fact that the requested documents related to proceedings of the Council, including the views expressed by

\footnotetext{
247 para. 119, n. 216 above.

248 paras. 94 and 120, n. 216 above.

249 para. 122, n. 216 above.

250 para. 123 , n. 216 above. Paragraph 15 of this judgment provides the details of the note dated 15 May 1995 prepared by the Director-General of the Council's Justice and Home Affairs Directorate.

251 para. 125 , n. 216 above.
} 
members of the Council, without saying whether it had made any comparative analysis which sought to balance, on the one hand, the interest of the citizens seeking the information and, on the other hand, the criteria for confidentiality of the proceedings of the Council. ${ }^{252}$

The Court concluded that the contested decision did not comply with the requirements to give reasons required by former Article $190 \mathrm{EC}$ and must be annulled. $^{253}$

\subsubsection{Comment}

Here, we examine the arguments of the two parties and the Court's opinion as to the procedural and substantive lawfulness of the contested decision.

\subsubsection{The applicant's interest}

A major issue concerning the procedural aspect of this case was whether the application was inadmissible in that the applicant had challenged the refusal in the public interest. There seemed to be no reason to prohibit the applicant from instituting the proceedings before the Court under Decision 93/731, which did not set out any limitation for an EU citizen seeking access to Council documents. The Council, however, said former Article 173 EC “only permits individuals to challenge acts which concern them in a way in which they do not concern other individuals". The CFI held, however, that the application was admissible, stressing that the

\footnotetext{
${ }^{252}$ para. 125 , n. 216 above. To support this view, the CFI cited para. 74 of the Carvel case. n. 18 above.

${ }^{253}$ para. 127, n. 216 above.
} 
applicant only needed to prove that it had an interest in the annulment of the decision, suggesting that citizenship was a sufficient requirement to challenge such a refusal.

\subsubsection{The Second and Third Pillar documents}

This judgment is a milestone in the development of EU FOI protection, as the Court ruled that the Second and Third Pillar documents held by the Council fell within the scope of Council documents under Decision 93/731. France said that in the absence of an express provision, Decision 93/731 did not apply to acts adopted on the basis of Title VI TEU. France argued that Decision 93/731 only applied to documents actually produced by the Council, rather than documents held by the Council relating to the three pillars. This statement suggested that it was unnecessary to consider whether the Third Pillar documents sought fell within the public security exception set out in Decision 93/731, as they were not even governed by this Decision. This view was, however, very controversial. In fact, the Council refused access to the 18 documents on the basis that they were "subject to the principle of confidentiality as laid down in Article 4(1) of Decision 93/731". This indicates that the Council did apply Decision $93 / 731$ to the information sought, and it was this application that led to the refusal.

The CFI disagreed with France, holding that "Decision 93/731, in Articles 1(2) and 2(2), expressly provides that it is to apply to all Council documents. Decision 93/731 therefore applies irrespective of the contents of the documents requested". The CFI read the term "Council documents" in a broad manner, regarding these documents as all documents held by the Council. This interpretation was appropriate

since it was in line with the principle of widest possible access in the Code of Conduct. Decision 93/731 would then be applicable to not only to the Third Pillar 
documents held by the Council, such as those sought in this case, but also to Second Pillar documents held by the Council.

At that time, the Second and Third Pillar documents not held by the Council and Commission remained unavailable for EU citizens under the legal framework of the Code of Conduct and the two corresponding decisions. This judgment, however, shows that the Court made a significant effort to enhance public scrutiny of the operation of the Second and Third Pillars in a context where general rules on freedom of information had not yet been adopted.

\subsubsection{Public security}

As to the substantive aspect of this case, a key issue was whether disclosure of the information was detrimental to one or more interests in Article 4 of Decision 93/731. The answer to this determines whether the contested decision should be annulled. The Council said that "it would not be in the interest of public security to allow those involved in illicit activities to obtain detailed knowledge of the structures and means available to police cooperation in the European Union". The applicant argued that the claim simply bore "no relation to the actual content of the documents in question". After examining the note prepared by the Council before the contested decision was made, the Court held that the information did not concern Europol's operation.

The CFI eventually annulled the contested decision, but this annulment was not based on the ground that the documents were irrelevant to the public interest, but on the Council's inappropriate invocation of Article 4 of Decision 93/731.

\subsubsection{Reliance on first, second, or both categories of exception?}

The second issue concerning the substantive lawfulness of the contested decision was 
whether the Council had properly applied Article 4 of Council Decision 93/731. The Council and Commission were entitled to invoke the first, second, or both categories of exception set out in the Code of Conduct, Decision 93/731, and Decision 94/90, when refusing requests. The situation here was analogous, though not exactly the same, to that of the $W W F$ case, where the Commission applied the two categories of mandatory and discretionary exceptions in a general fashion. In the present case, the Council had the choice to invoke a first-category mandatory exception set out in Decision 93/731. The Council could have refused the request on the basis that disclosure of the documents concerned could be detrimental to the public interest relating to public security. It could, in the alternative, have applied the second-category discretionary exception on the ground that all the information had been under discussion at the Council meetings. In this case, however, the Council attempted, unsuccessfully, to invoke both categories simultaneously. This approach indicates once again that the distinction between the two categories was extremely unclear. As the Court found it difficult to ascertain whether the Council was applying the first, second, or both categories, it decided to annul the refusal.

It can be concluded that the CFI annulled the contested decision owing to the Council's insufficiently detailed invocation of the two categories of exception. The Court emphasised the Council's duty to specify the legal basis for a refusal, and to balance the interest of those seeking access to the information and the criteria for confidentiality of the proceedings of the Council. Unfortunately, the Court did not clearly establish the scope of the public security exception. As Professor Carol Harlow has said, the CFI annulled the decision "only on the narrow ground that inadequate reasons for refusal had been given, a 'halfway house' solution which 
allows for further refusal, based on more appropriate grounds". ${ }^{254}$

\subsection{The Rothmans case $\mathrm{e}^{255}$}

The case law examined in this study to date has mainly concerned the mandatory and discretionary exceptions set out in the fourth section of the Code of Conduct and Article 4 of Decision 93/731. ${ }^{256}$ However, the analysis of the Code of Conduct and the corresponding Council and Commission decisions, as we have seen in 3.1, reveals that there was another exception other than these two categories. This was that the Council and Commission would not provide the citizens with documents produced by the other EC institutions or bodies. The Code of Conduct states that "[w]here the document held by an institution was written by a natural or legal person, a Member State, another Community institution or body or any other national or international body, the application must be sent direct to the author".

In Rothmans, the Commission invoked this rule on authorship when refusing access to minutes of a comitology committee. This issue was of considerable importance. The three measures noted above only applied to the Council and Commission rather than all the Community institutions and bodies, which meant that it could be very difficult for the citizens to access documents of comitology committees if the CFI held that this kind of information was not covered by Decision

\footnotetext{
${ }^{254}$ Harlow, n. 7 above, at 164 .

${ }^{255}$ Case T-188/97, Rothmans International BV v. Commission [1999] ECR II-2463.

256 The 1996 Netherlands judgment, as we saw in 3.3, is the only exception, as it primarily concerns the legal basis of Decision 93/731 and whether freedom of information should be regarded as a fundamental human right.
} 
94/90. A tough challenge for the Court was how to conclude that the Committee minutes were covered by Decision 94/90, when it was unclear whether comitology committees constituted an integral part of the Commission.

\subsubsection{Facts}

A Dutch company, Rothmans International BV, manufactured, distributed, and sold tobacco products. ${ }^{257}$ The applicant requested from the Commission access to certain documents including minutes of the Customs Code Committee - Transit Section (hereinafter "the Committee"). ${ }^{258}$ In a letter of 30 April 1997, the Secretary-General of the Commission forwarded a number of its documents but refused to offer the Committee minutes since the Commission was not their author. ${ }^{259}$ The Secretary-General told the applicant by another letter that "while the minutes are drawn up by the Commission in its secretarial capacity, they are adopted by the Committee, which is therefore their author". ${ }^{260}$ The applicant then brought the present action, claiming that the CFI should annul the Commission decision of 30 April 1997, while the Commission said the Court should dismiss the application. ${ }^{261}$

The applicant, supported by Sweden, put forward two pleas in support of its action. The first plea alleged infringement of former Article 190 EC (now Article 253 EC) and the second infringement of Decision $94 / 90 .^{262}$ As to the first plea, the applicant submitted that the contested decision was vitiated by defective

${ }_{258}^{257}$ para. 9 , n. 255 above.

${ }_{258}$ para. 10, n. 255 above.

259 para. 16, n. 255 above.

260 para. 18, n. 255 above.

${ }^{261}$ paras. 20,26 , and 27, n. 255 above.

${ }^{262}$ para. 34, n. 255 above. 
reasoning. ${ }^{263}$ Rothmans might have elaborated on this plea when seeking the annulment, and the Commission might have responded to this elaboration, but the Court in its judgment referred to neither the applicant's statement nor the Commission's response. As to the applicant's second plea alleging infringement of Decision 94/90, the applicant said the Commission infringed Decision 94/90 through its refusal, in reliance on the authorship rule, to grant access to the Committee minutes. ${ }^{264}$ Rothmans said the Commission drew up the minutes, so by virtue of this work the Commission was, "materially and intellectually, the author of those documents". ${ }^{265}$ It stressed that the Committee's Chairman was a Commission official, and it was a Commission representative who convened the Committee and drew up its agenda. ${ }^{266}$ The company said the authorship rule was by contrast designed to protect third-party documents. ${ }^{267}$

The Commission responded that it made the refusal since the information did not fall within the category "Commission documents". ${ }^{268}$ It denied that it was the minutes' author and said Decision 94/90 only applied to those documents of which it was the author. ${ }^{269}$ It said the mere fact that it undertook technical work, such as secretarial services for the Committee, was not sufficient to confer authorship on it, since that was "determined by 'intellectual possession' of the text". ${ }^{270}$ It said the Committee approved the minutes, which was solely responsible for its deliberations. ${ }^{271}$ Sweden disagreed with the Commission and argued that:

\footnotetext{
${ }^{263}$ para. 35 , n. 255 above.

264 para. 39 , n. 255 above.

265 para. 40 , n. 255 above.

${ }_{266}$ para. 41, n. 255 above.

267 para. 41 , n. 255 above.

268 para. 42 , n. 255 above.

269 paras 43 and 44, n. 255 above.

270 para. 44 , n. 255 above.

271 para. 44 , n. 255 above.
} 
[I]f "comitology" committees were to be regarded as separate bodies, this would mean that the documents of such committees would fall outside the scope of the rules adopted in relation to public access to Council and Commission documents. An individual wishing to obtain access to the work of the committees would then be dependent on the committees' exercise of their own discretion, without any possibility of judicial review. ${ }^{272}$

\subsubsection{Held}

Addressing the applicant's first plea that alleged infringement of former Article 190 EC, the Court stated that the Commission provided reasons for the contested decision by referring to the authorship rule and by confirming that, by virtue of that rule, the applicant's request was inadmissible on the ground that the author of the documents sought was a third party. ${ }^{273}$ The Court said such reasoning was sufficiently clear to enable the applicant to understand why the Commission did not forward to it the documents at issue. ${ }^{274}$ It therefore ruled that this plea must be rejected. ${ }^{275}$

As to the second plea alleging infringement of Decision 94/90, the Court stated that the authorship rule set out "an exception to the general principle of transparency in Decision 94/90". ${ }^{276}$ It stated that "this rule must be construed and applied strictly, so as not to frustrate the application of the general principle of transparency". ${ }^{277}$ Referring to Article 145 EC (now Article 202 EC) and the Council decision laying down the procedures of the exercise of implementing powers conferred on the Commission, the Court said that "the Committee cannot be regarded as being

\footnotetext{
272 para. 50 , n. 255 above.

273 para. 37 , n. 255 above.

274 para. 37 , n. 255 above.

275 para. 38 , n. 255 above.

276 para. 55, n. 255 above.

277 para. 55, n. 255 above.
} 
'another Community institution or body' within the meaning of the Code of Conduct adopted by Decision 94/90". ${ }^{278}$ It also stated that "refusal of access to the minutes of the numerous 'comitology' committees would amount to placing a considerable restriction on the right of access to documents", adding that such a restriction was incompatible with the very objective of the right of access to documents. ${ }^{279}$ Thus, "it must be held that, for the purposes of the Community rules on access to documents, 'comitology' committees come under the Commission itself. It is therefore the Commission which is responsible for ruling on applications for access to documents of those committees, such as the minutes here in question". 280

The Court stated that " $[\mathrm{t}]$ he Commission was therefore not entitled, in this case, to refuse access to the minutes of the Committee by invoking the rule on authorship set out in the Code of Conduct adopted by Decision 94/90. It follows that it infringed that decision in adopting the contested decision". ${ }^{281}$ The Court, therefore, ruled that the second plea must be upheld and that the contested decision must be annulled. ${ }^{282}$

\subsubsection{Comment}

The two pleas forwarded by the applicant alleged infringement of former Article 190 EC and of Decision $94 / 90$, i.e. failure to meet the requirement to state clear reasons

\footnotetext{
278 para. 59, n. 255 above. Former Article 145 EC provides that the Council shall, inter alia, "confer on the Commission, in the acts which the Council adopts, powers for the implementation of the rules which the Council lays down", to ensure that the objectives of this Treaty are attained. Council Decision of 13 July 1987 lays down the procedures for the exercise of implementing powers conferred on the Commission, 87/373/EEC [1987] OJ L197/33.

${ }^{279}$ para. 61, n. 255 above.

280 para. 62 , n. 255 above.

${ }^{281}$ para. 63, n. 255 above.

282 para. 64, n. 255 above.
} 
and improper invocation of the authorship rule. The CFI rejected the first plea because the invocation of the authorship rule was sufficient. It agreed on the second plea, annulling the contested decision since the authorship rule did not entitle the Commission to make the refusal. This ruling benefited the EU citizens as far as FOI protection was concerned, but it remains necessary to examine the reasoning behind this judgment, in particular the grounds for determining the Committee's legal status.

\subsubsection{Sufficient reasoning}

As to the first plea concerning whether the refusal infringed former Article $190 \mathrm{EC}$, the CFI said the Commission provided reasons for the refusal by referring to the authorship rule and by confirming that, by virtue of that rule, the applicant's request was inadmissible since the author of the documents sought was a third party. The CFI rejected this plea mainly because such reasoning was sufficiently clear to enable Rothmans to understand why the Commission did not provide the documents at issue.

What constitutes sufficient reasons as regards former Article $190 \mathrm{EC}$ and the denial of a request for access to the information held by the EC institution? First, decisions such as the refusal concerned, according to Article 190 EC, "shall state the reasons on which they are based". This requirement is an obligation to give clear reasons, which should not be regarded as a mere indication of source of legal authority. In addition to specification of legal basis, more reasons are expected. As regards what constitutes sufficient reasoning, Professor Trevor Hartley has stated that:

[These reasons] must at the very least set out the factual background which the 
author of the act regards as relevant; they must specify the Treaty provision (or other source of legal authority) under which the act was adopted (its legal basis); they must state the objectives which the act is designed to attain; and they should state why, in the opinion of the enacting authority, it is desirable to attain these objectives. ${ }^{283}$

As to the present case, the Commission had therefore to meet the sub-requirements derived from the obligation to state reasons laid down in Article 190 EC. Thus, the Commission in its refusal had to indicate the legal basis for the decision before indicating the objectives that the decision was intended to achieve. Additionally, it had also to establish why it was desirable to accomplish those purposes.

Were these sub-requirements met in the present case? As noted above, the Secretary-General of the Commission told the applicant in a letter that, "while the minutes are drawn up by the Commission in its secretarial capacity, they are adopted by the Committee, which is therefore their author". It is obvious that this refusal did not infringe Article 190 EC because, on the one hand, the Commission clearly pointed out that this refusal was based on the authorship rule. On the other hand, the Commission said that it invoked this rule because the Committee was the only author of the information concerned. The CFI was, therefore, right when stating that the Commission's reasoning was sufficiently clear to enable Rothmans to understand why the Commission did not provide the documents at issue.

\subsubsection{Documents produced for comitology committees}

As regards the applicant's second plea alleging infringement of Decision 94/90, the applicant, Sweden, and the Commission focused on whether the Committee

${ }^{283}$ Hartley, n. 105 above, at 127. 
constituted an integral part of the Commission, as the answer would help determine whether the Committee minutes were Commission documents and, eventually, whether the Commission should be considered the minutes' author.

Comitology is the web of committees made up primarily of national officials and experts, and chaired by the Commission, which oversees the implementation of EU legislation. ${ }^{284}$ The Commission said the Committee minutes were not Commission documents and it did not have authority to decide whether the applicant should be granted access to the minutes. The Commission stressed that Decision 94/90 applied only to the documents of which it was the author, but it was not the author of the minutes. Sweden, however, said if comitology committees were to be regarded as separate bodies, a request for access to the committees' work would be dependent on their discretion. Sweden rightly pointed out it would be difficult for EU citizens to access the committees' minutes if they were considered documents of separate bodies.

The CFI first addressed the status of the authorship rule before considering whether the Commission was the minutes' author. The Court stated that the authorship rule laid down an exception to the general principle of transparency in Decision 94/90. This statement indicated that the authorship rule was an exception distinct from the mandatory and discretionary exceptions. However, the Court simply addressed the second dispute technically, annulling the contested decision without touching on the role of the authorship rule or looking at whether disclosure of the information sought could be detrimental to the Committee's interest.

The CFI then stated that it did not regard the Committee as an EC institution or body within the meaning of the Code of Conduct adopted by Decision 94/90. It

\footnotetext{
284 Bomberg and Stubb, n. 3 above, at 231.
} 
stated that "refusal of access to the minutes of the numerous 'comitology' committees would amount to placing a considerable restriction on the right of access to documents", adding that "[s]uch a restriction is not compatible with the very objective of the right of access to documents". These statements indicate that the Court, after examining the "very objective of the right of access to documents", held that the minutes concerned were within the scope of Decision 94/90. The Court, therefore, concluded that "for the purposes of the Community rules on access to documents, 'comitology' committees come under the Commission itself'. This demonstrated that those committees constituted an integral part of the Commission with respect to the rules on access.

In the present case, the Court undoubtedly stood on the side of the EU citizens. This judgment secured the interest of those who wished to obtain information of the comitology committees at a time when there was no general FOI legislation applicable to all EC institutions and bodies. The Court made this decision to accomplish the purposes of the right of access, but its views on the status of comitology committees were contentious. Here, we consider whether comitology committees can be treated as part of the Commission, analysing factors other than FOI protection, such as who approves the minutes and the extent to which decisions of the committees limit the power of the Commission.

First, it seemed that the Court was not careful enough when considering the applicant and the Commission's arguments regarding the status of the committees. The Commission said that authorship should be determined by "intellectual possession" of the text at issue. It was the Committee rather than the Commission that approved the minutes, though the documents were drawn up by the Commission. Second, as regards the relations between the two bodies, the committees can in 
certain circumstances prevent the Commission from proceeding with a measure without their approval. ${ }^{285}$ It was, therefore, difficult for the Commission to view the committees as an integral part of itself when its power was in fact limited by the committees. In other words, the Commission did not read the term "Community institution or body" in a broad sense. The Court, however, failed to consider carefully the committees' unique status in EC law. It ignored the fact that the Committee in question, in common with the other comitology committees, was not under the Commission's control. As Professor Carol Harlow has said, "[t]he Comitology, as with all committees, has assumed a life of its own" ${ }^{286}$ Comitology committees are not a part of the Commission though they are not entirely distinct from the institution. The Court strictly interpreted the term "another Community institution or body", to attain the objective of the Code of Conduct, i.e. "widest possible access", but it did not take the factors noted above into serious account.

This judgment was thus flawed in certain ways, but many at that time were pleased to see the objective of Community rules on access being attained through Decision 94/90. This is because, without this decision, it would have been very difficult for EU citizens to access the minutes of the hundreds of committees, which together spent about 19.5 million Euros in $1998 .^{287}$ In fact, citizens at that time had not yet been granted the right to survey the participation of the hundreds of national and EU bureaucrats and experts in comitology meetings in Brussels on a daily basis.

\footnotetext{
${ }^{285}$ Ibid.

${ }^{286}$ Harlow, n. 7 above, at 67.

${ }^{287}$ C. Joerges, and E. Vos (eds.), EU Committees: Social Regulation, Law and Politics (Oxford, Hart Publishing, 1999), 20.
} 


\subsubsection{Conclusion}

First, it follows from the examination above that former Article $190 \mathrm{EC}$ required that the Council and Commission when refusing access to documents had to specify the legal basis for the decision before indicating the objectives that the decision was intended to achieve. Additionally, the reasons why they planed to accomplish those purposes had also to be stated. In the present case, the refusal, which did not infringe Article $190 \mathrm{EC}$, indicated that the authorship rule placed considerable power in the hands of the Council and Commission. When the Council or Commission invoked this rule, they were entitled to deny access to all documents produced by third parties, even if they were held by these two institutions.

Second, the CFI held that the comitology committees' minutes were within the scope of Decision 94/90, in order to avoid frustrating the principle of widest possible access laid down in the Code of Conduct. The CFI made this decision in the EU citizens' interest in obtaining information but paid little attention to the committees' unique status in EC law. In the long run, however, a heavy responsibility should be laid on the shoulder of the EU legislator, because only adoption of general rules applicable to all community institutions and bodies, including the comitology committees, would put an end to the controversy concerning their status. With such general legislation, it would no longer be necessary for the Court to distort the comitology committees' true status in EC law when giving effective FOI protection. 


\subsection{The Hautala case}

Article 4(1) of Council Decision 93/731 provided that access to a Council document should not be granted where its disclosure could undermine the protection of the public interest relating to public security, international relations, and monetary stability, as well as court proceedings, inspections and investigations. According to Article 1, the term "document" in Decision 93/731 referred to any written text, whatever its medium, which contained existing data held by the Council. However, these rules did not offer, at least not expressly, the solution to the main problem in the Hautala case addressed by the $\mathrm{CFI}^{288}$ and then the $\mathrm{ECJ}^{289}$. The dispute was whether the Council should consider affording partial access to a document that contained information whose disclosure could undermine the public interest. Should, that is, the Council refuse a request for access to a document, part of which was not at all detrimental to the public interest?

\subsubsection{Facts}

Ms. Heidi Hautala was a Member of the European Parliament. ${ }^{290}$ She requested from Secretary-General of the Council a report made by the Common Foreign and Security Policy (CFSP) Working Group on Conventional Arms Exports, which the Council's Political Committee had approved to enhance consistent implementation of

288 Case T-14/98, Hautala v. Council [1999] ECR II-2489.

289 Case C-353/99P, Council v. Hautala [2001] ECR I-9565.

${ }^{290}$ para. 13, n. 288 above. 
common criteria for arms exports. ${ }^{291}$ The Secretary-General refused the request under Article 4(1) of Decision 93/731, as disclosure of the "highly sensitive information" contained in the report "would undermine the public interest, as regards public security". ${ }^{292}$ Ms. Hautala made a confirmatory application, which the Council rejected by letter of the 4 November 1997 (hereinafter "the contested decision") since disclosure of the report "could be harmful for the EU's relations with third countries. Access to the document in question is therefore to be refused by virtue of Article 4(1) of Decision 93/731/EC in order to protect the public interest with regard to international relations". 293

The applicant later brought this case before the CFI. The Council did not challenge the CFI's jurisdiction, but France, supporting the Council in this case, submitted that the application was not within the Court's jurisdiction. France said by virtue of Article L TEU (now Article 46 TEU), it considered that "where the Council has decided to apply Decision 93/731 to documents falling within Title V, its decisions on access to such documents also come under Title V and, as such, may not be the subject of an action under Article 173 of the EC Treaty". ${ }^{294}$ The CFI held that it had jurisdiction to hear the application, stating that the fact that the report came under Title V "has no effect on the jurisdiction of the Court". It also said it had held in Svenska Journalistförbundet that Decision 93/731 applied to "all Council documents, irrespective of their content". 295

The applicant put forward a plea alleging infringement of Article 4(1) of

\footnotetext{
291 paras. 15 and 16, n. 288 above. The European Council defined eight criteria in 1991 in Luxembourg and 1992 in Lisbon. para. 14, n. 288 above.

292 para. 18 , n. 288 above.

293 paras. 19 and 21, n. 288 above.

294 paras. 36 and 37 , n. 288 above.

295 para. 41 , n. 288 above, in which para. 81 of the Svenska Journalistförbundet judgment was referred to. See 3.7.2.
} 
Decision 93/731. The Council said the principle of access to documents applied "only to documents as such, not to the information contained in them". 296 The CFI disagreed. First, as Decision 93/731 did not require or prohibit the Council to consider whether partial access to documents might be granted, the basis on which the Council adopted Decision 93/731, in particular the principle of widest possible access in the Code of Conduct, "must be borne in mind for the purpose of interpreting Article 4 of that decision", the CFI stated. ${ }^{297}$ Second, it stated that the principle of proportionality required that "derogations remain within the limits of what is appropriate and necessary for achieving the aim in view". ${ }^{298}$ It also held that the aim pursued by the Council when refusing the request was to "protect the public interest with regard to international relations". It held that "[s]uch an aim may be achieved even if the Council does no more than remove, after examination, the passages in the contested report which might harm international relations". ${ }^{299}$

Accordingly, the CFI stated that "Article 4(1) of Decision 93/731 must be interpreted in the light of the principle of the right to information and the principle of proportionality. It follows that the Council is obliged to examine whether partial access should be granted to the information not covered by the exceptions". 300 Nonetheless, "the Council did not make such an examination, since it considers that the principle of access to documents applies only to documents as such and not to the information contained in them. Consequently, the contested decision is vitiated by an error of law and must therefore be annulled", 301

\footnotetext{
296 para. 75 , n. 288 above.

297 paras. 78, 79, and 81 , n. 288 above.

298 para. 85 , n. 288 above, in which para. 38 of Case 222/84, Johnston v. Chief Constable of the Royal Ulster Constabulary [1986] ECR 1651 was referred to.

299 para. 85 , n. 288 above.

300 para. 87, n. 288 above.

301 para. 89 , n. 288 above.
} 
The Council brought an appeal to the ECJ, reiterating that Decision 93/731 provided for access to documents rather than information. ${ }^{302}$ It argued that the CFI had erred "by deducing from Decision 93/731 an obligation on the Council not to grant a request for access to a document, but to edit the document and thus create a new document containing only the information capable of being disclosed, solely in order to supply 'information' to the public". ${ }^{303}$ It said no right of partial access to Council documents might be derived from the principle of proportionality, without elaborating on what it conceived this principle required. ${ }^{304}$ In response, Ms. Hautala said that "the contested judgment correctly interpreted Decision 93/731 by requiring the Council to consider granting partial access to documents which contain information covered by the exceptions laid down in Article 4(1) of that decision", 305 She said that Article 255(1) EC “confirms the citizen's fundamental right of access to the documents of the institutions". 306

\subsubsection{Held}

Examining the origin of Decision 93/731, in particular the principle of widest possible access, the ECJ held that the Council was "wrong in submitting that that decision concerns only access to 'documents' as such rather than to the information contained in them" ${ }^{307}$ It stated that the Council's interpretation of Article 4(1) would frustrate the public's right of access to the items of information contained in a

\footnotetext{
${ }^{302}$ para. 11, n. 289 above.

303 paras. 9 and 11, n. 289 above.

304 para. 13, n. 289 above.

305 paras. 15 and 16, n. 289 above.

306 para. 20 , n. 289 above.

307 para. 23, n. 289 above.
} 
document not covered by the exceptions in Article $4(1):{ }^{308}$ " $[\mathrm{t}]$ he effectiveness of that right would thereby be substantially reduced". ${ }^{309}$ It held that the CFI had not erred "by holding that the principle of proportionality also requires the Council to consider partial access to a document which includes items of information whose disclosure would endanger one of the interests protected by Article 4(1) of Decision $93 / 731$ " ${ }^{310}$ It also stated that "a refusal to grant partial access would be manifestly disproportionate for ensuring the confidentiality of the items of information covered by one of those exceptions". ${ }^{111}$ It held that the CFI was right to annul the contested decision on finding that the Council had not examined whether partial access should be granted to the information not covered by the exceptions in Article 4(1). ${ }^{312}$ It therefore dismissed the appeal. ${ }^{313}$

\subsubsection{Comment}

This case concerns a number of key issues in the FOI area. We first consider whether Decision 93/731 applied to Second Pillar documents held by the Council. Second, we examine whether the Council was obliged to consider granting partial access to the information not covered by the exceptions in Article 4(1) of Decision 93/731. This issue concerns the way the term "document" in Decision 93/731 should be understood and the review of proportionality made by the Courts when addressing this dispute.

\footnotetext{
308 para. 26 , n. 289 above.

309 para. 26 , n. 289 above

310 para. 27 , n. 289 above.

311 para. 29, n. 289 above.

312 para. 31 , n. 289 above.

313 para. 32 , n. 289 above.
} 


\subsubsection{Access to Second Pillar documents}

The information sought by Ms. Hautala covered documents produced by the CFSP Working Group on Conventional Arms Exports under the framework of the Second Pillar. France, supporting the Council in this case, challenged the CFI's jurisdiction, though the Council did not itself raise this point. France said by virtue of Article L TEU (now Article 46 TEU), "where the Council has decided to apply Decision 93/731 to documents falling within Title V, its decisions on access to such documents also come under Title $\mathrm{V}$ and, as such, may not be the subject of an action under Article 173 of the EC Treaty". This statement suggested that, as the contested decision concerned documents falling within Title V TEU, the Court had no jurisdiction in relation to that decision. In other words, France believed it was the nature of the documents concerned that determined whether the Courts had jurisdiction.

This argument was debatable. Article 173 EC provides that "[t]he Court of Justice shall review the legality of acts of the Council and the Commission other than recommendations or opinions". The authors of the EC Treaty defined reviewable acts by means of a negative definition, merely excluding recommendations and opinions. All the other acts of the Council and Commission, according to Article L TEU, were reviewable unless they directly concerned matters of the Second and Third Pillars. Article L TEU was insufficient for France to conclude that the contested decision might not be the subject of an action under Article $173 \mathrm{EC}$. This is because although the jurisdiction of the Court, according to Article L, was largely excluded with regard to matters of the CFSP, the refusal at issue related mainly to the application of a Council decision, rather than the operation of the CFSP.

In response to the challenge by France, the CFI said it had jurisdiction to hear 
the application, stating that " $[\mathrm{t}]$ he fact that the contested report comes under Title V of the Treaty on European Union has no effect on the jurisdiction of the Court". The CFI, surprisingly, did not continue to examine the scope of the Community courts' jurisdiction concerning Article $173 \mathrm{EC}$ and Article L TEU, as we have done above. What it did was to resort to its Svenska Journalistförbundet judgment. The CFI read the phrase "Council documents" in a broad manner, regarding those documents as all the information held the Council. The Court stated in that case that Decision 93/731 applied to all Council documents irrespective of the contents of the documents requested. ${ }^{314}$ In the present case, the CFI referred to Svenska Journalistförbundet, reaffirming that Decision 93/731 applied to the Second and Third Pillar documents.

This reasoning was far from perfect because, first, neither the Council nor France denied that Decision 93/731 applied to documents relating to the two pillars. Second, the CFI did not even mention Article 173 EC and Article L TEU in its judgment. Third, the Court appeared to have assumed that, as Decision 93/731 applied to the Second Pillar documents, it had jurisdiction over decisions relating to access to the documents. The Court did not tackle head on the challenge by France. However, although there was lack of sound reasoning in this judgment, the Court's view as to its jurisdiction to hear the application was correct, given the conclusion of our examination of former Article 173 EC and Article L TEU noted above. ${ }^{315}$

\subsubsection{Partial access versus administrative burden}

Another key issue was whether the Council was obliged to consider granting partial access to the information not covered by the exceptions in Article 4(1) of Decision

\footnotetext{
See 3.7, in particular 3.7.3.2 above.

315 See the second paragraph of this subsection.
} 
93/731. The Council said that the CFI had erred by deducing from Decision 93/731 an obligation on the Council to edit a document and create a new document containing only the information capable of being disclosed, solely to supply information to the public. First, Decision 93/731 did not require or prohibit the Council to consider the granting of partial access. Second, editing Council documents could become an additional administrative burden on the Council, irrespective of whether the CFI rightly interpreted the term "documents" within the meaning of Article 4(1) of Decision 93/731. Thus, a serious question was in what circumstances does freedom of information prevail over the interest of good administration.

The Courts, however, held that the Council was obliged to examine whether partial access should be granted to the information not covered by the exceptions. The Courts came to this conclusion since Article 4(1) of Decision 93/731 had to be interpreted in the light of the principle of the right to information on the one hand, and the principle of proportionality on the other. Here, we examine these two issues. The Courts, first, read Article 4(1) primarily in reliance on the principle of widest possible access in the Code of Conduct. Ms. Hautala stated before the ECJ that Article 255(1) EC, inserted by the Amsterdam Treaty, had confirmed the citizen's fundamental right of access to the documents of the institutions. It was, however, improper to present this argument before the ECJ, because that Treaty came into force in 1999, which should not be considered the origin of Decision 93/731 adopted in 1993. This is presumably why the ECJ did not refer to Article 255(1) EC but turned to consider the Code of Conduct to ascertain the origin of freedom of information.

Second, the Courts, which applied the principle of proportionality when 
addressing this dispute, should be praised for making this unprecedented effort in the EU FOI field. This principle requires a reasonable relationship between the end and the means. It implies both that the means must be reasonably likely to bring about the objective, and that the detriment to those adversely affected must not be disproportionate to the benefit to the public. ${ }^{316}$ In this judgment, the ECJ rightly pointed out that "a refusal to grant partial access would be manifestly disproportionate for ensuring the confidentiality of the items of information covered by one of those exceptions". We should, however, keep a close eye on how the Court applies this general principle of EC law in the relevant case law. This is because, first, this general principle derived from German law can be applied to examine not only a refusal based on protection of international relations, but also all the other kinds of exemptions to openness. Second, this principle leaves a great deal to the judgment of the Court. Professor Trevor Hartley has asked: "Is the measure reasonably likely to attain its objective? Does it impose disproportionate burdens on those concerned? These are clearly questions on which opinions may frequently differ. The Court will not, of course, interfere unless there is a clear and obvious infringement of the principle". ${ }^{317}$ The way the Community courts apply this principle under the 2001 Regulation is clearly an important issue and is considered further at 3.10.2 and 8.2.4

\footnotetext{
${ }^{316}$ It is to some extent analogous to the English concept of reasonableness. Hartley, n. 105 above, at 152.

${ }^{317}$ Professor Hartley also states that it is not always easy to predict when the Court will consider that there is a clear infringement of the principle. Hartley, n. 105 above, at 152-153. The intensity with which the Court applies this principle has been a crucial and complex issue. Professor Takis Tridimas says that "[f]ar from dictating a uniform test, [the principle of proportionality] is an open-textured principle which is used in different contexts to protect different interests, and it entails different degrees of judicial scrutiny". T. Tridimas, 'Proportionality in European Community Law: Searching for the Appropriate Standard of Scrutiny,' in E. Ellis (ed.), The Principle of Proportionality in the Laws of Europe (Oxford, Hart Publishing, 1999), 84. Professor Gráinne de Búrca has also said that it becomes apparent that "the way the proportionality principle is applied by the Court of Justice covers a spectrum ranging from a very deferential approach, to quite a rigorous and searching examination of the justification for a measure which has been challenged". G. de Búrca, "The Principle of Proportionality and its Application in EC Law,' in A. Barav and D. Wyatt (eds.), Yearbook of European Law (Oxford, Clarendon Press, 1993) vol 13, 111.
} 
below.

\subsubsection{Conclusion}

The Courts correctly interpreted the scope of the term "a document" in this case. This phrase should be understood as meaning any information contained in a document.

Generally, the Courts favoured Ms. Hautala in the present case, but this did not mean that she would eventually receive the information she sought from the Council. Although the ECJ dismissed the Council's appeal, the Court seemed to agree with the institution on its claim that the report contained highly sensitive information, which would undermine the public interest. The Court addressed the present case technically, demanding that the Council consider granting Ms. Hautala partial access to the information not covered by the public interest exception relating to international relations. In other words, the Courts did not consider whether disclosure of the requested report could be detrimental to the protection of international relations, or what the limit of the protection was.

What Ms. Hautala sought was the complete report on arms exports, but what she might receive eventually could be immaterial parts of the contested report. The information sought was a report approved by the Council's Political Committee intended to enhance consistent implementation of common criteria for arms exports. We doubt whether disclosure of the witheld part of the report could be detrimental to the public interest. This is because, first, the Council did not elaborate on why disclosure of the report would harm the EU's relationships with third countries. Second, the Secretary-General of the Council refused Ms. Hautala's request originally on the basis of the public security exception. The official, however, altered his view before the ECJ and turned to rely on the international relations exception. 
We, therefore, suspect that the invocation of the two exceptions was just an attempt to escape public scrutiny on the EU's sales of weapons.

\subsection{Key issues}

This chapter has examined in detail the Code of Conduct, the two corresponding Council and Commission decisions, and the relevant case law. The primary objective of this analysis, as stated at the beginning of this chapter, is to capture a clear picture of the controversial issues surrounding FOI protection between 1993 and 2000. Here we draw out the main features of the development of the law during this period.

\subsubsection{The principle of "widest possible access"}

The general principle of the Code of Conduct is that "[t]he public will have the widest possible access to documents held by the Commission and the Council". This rule appeared to be merely a hortatory statement since it was followed by a long list of exceptions to openness. However, the Community courts improved the FOI regime by identifying this commitment to openness as the main purpose behind the Code of Conduct when addressing relevant disputes. This purpose proved to be

particularly important where disputes stemmed from the vagueness of the Code of Conduct. 
In Carvel, the first key case in this second stage, the applicant said that under Article 4(2) of Council Decision 93/731, which protected the confidentiality of the Council's proceedings, the Council must carefully balance the interests involved before deciding whether access to a document is to be refused. In fact, Article 4(2) did not expressly put the Council under such an obligation, but the CFI accepted the applicant's view applying the principle of widest possible access. Similarly, in Hautala, although Decision 93/731 did not require or prohibit the Council from considering whether partial access to documents might be granted, the CFI and ECJ held that the institution was obliged to do so. This decision was also based on the principle of widest possible access coupled with the principle of proportionality. These examples show that the Courts made use of the stated principle of widest possible access to reduce the scope of the exceptions.

\subsubsection{Delimiting the exceptions to openness}

\subsubsection{The Courts' primary stance}

The extensive mandatory and discretionary exceptions in the Code of Conduct and Decision 93/731 appeared to run counter to the principle of widest possible access. What was worse was that the Council and Commission at this second stage made every attempt to extend the two categories of exception. The analysis of the case law reveals that these two institutions afforded the exceptions a dangerously extensive scope, which was likely to make the commitment to widest possible access an empty statement. The Courts in most of the disputes acted to defend freedom of information. What they achieved was not the establishment of individual limitations to each of the 
exceptions invoked by the institutions, but rather general principles of review. Their primary stance on this issue can be found in the $W W F$ judgment, in which the CFI said where a general principle was established and exceptions to that principle were laid down, the exceptions should be construed and applied strictly, in a manner which would not defeat the application of the general rule. This statement can be considered the Courts' fundamental position on the institutions' invocation of the exceptions.

This commitment to openness was in practice realised through application of a Treaty provision and a general principle of Community law, i.e. the clear reasoning test set out in Article 253 EC (ex Article 190 EC) and the principle of proportionality, when the Courts made an effort to reduce the scope of the exceptions.

\subsubsection{Article $253 \mathrm{EC}$ and the principle of proportionality}

The CFI in the WWF, Interporc $I$, and Rothmans judgments agreed with the applicants that the Commission refusals should have met the requirement to provide sufficient and clear reasons as set out in Article 253 EC. As regards FOI protection, Article 253 requires that the Council and Commission indicate the legal authority for a refusal before stating the objectives that the refusal is to achieve. In addition, the institutions should also establish why it is desirable to accomplish those purposes.

In the EU FOI field, the role of Article $253 \mathrm{EC}$ is to some extent analogous to that of the principle of proportionality applied by the Community courts in the Hautala case. This principle requires that there exits a reasonable relationship between the end and the means, a requirement applied in Hautala by the ECJ, which held that "a refusal to grant partial access would be manifestly disproportionate for ensuring the confidentiality of the items of information covered by one of those exceptions". In its Hautala judgment, the ECJ did not refer to Article 253 EC but 
applied the principle of proportionality, effectively to restrict the Council's invocation of the international relations exception. This principle should be expressly stated in a prominent place in the 2001 Regulation, a point discussed in more detail in Chapters 5 and 8, and the Courts' future application of this principle in the FOI field should be carefully monitored.

Generally, the Courts played the role of guardian of freedom of information when addressing disputes, but this was not always the case. In Carlsen, for instance, the Council failed to establish why release of the information sought could damage "the maintenance of legal certainty" and "the stability of Community law and the Council's being able to obtain independent legal advice". The CFI, however, held that reference to the two reasons "must be considered to be sufficient". In van der Wal, the CFI upheld the Commission's refusal of a lawyer's request for access to three letters, which contained legal opinions provided by the Commission to three national courts. The applicant submitted that the reasons given by the Commission were insufficient, but the CFI decided that the three letters fell within the scope of the court proceeding exception, without stressing the requirement set out in Article 253 EC.

\subsubsection{The balancing test and the principle of proportionality}

The CFI established a specific limit to the exception relating to internal proceedings, namely the balancing of interests test, in the Carvel judgment, the first key FOI decision during the second stage. The Court in this judgment put the Council under an obligation to balance the citizens' interest in accessing Council documents against its interest in maintaining confidentiality. The CFI in Carvel annulled the refusal mainly on the ground that the Commission did not undertake a genuine balancing of 
the interests involved. The CFI later applied the balancing test once again in $W W F$, stating that the refusal referred to the internal proceedings exception but failed to carry out any balancing of the interests involved. The stress on this test indicated that the scope of the internal proceedings exception in the Court's view was much narrower than that held by the institutions.

The balancing test played a role analogous to that of the principle of proportionality when applied to secure freedom of information. The principle of proportionality emphasises a reasonable relationship between the end and the means. As regards FOI protection, the end is to maintain the various kinds of interest listed in the two categories of exception and in the authorship rule, while the means is a refusal of request for access to the EC institutions' information. A reasonable measure in this field is certainly a refusal that strikes the balance between the interests noted above and those of the citizens in accessing the information.

\subsubsection{An indistinct dividing line between the mandatory and discretionary exceptions}

In $W W F$, the CFI said the mandatory exceptions guaranteed the interest of third parties or of the general public, while in relation to the confidentiality exception, only the Commission's interest was at stake. This distinction established by the Court appeared to be a significant achievement, because it indicated that the institutions must invoke a first-category mandatory exception when refusing a request to secure the public interest. The second category of discretionary exception, namely the internal proceedings exception, could only be invoked where a document concerning the institutions' interest was at stake. Otherwise their refusals would be annulled.

The distinction, however, is of little importance in practice. The examination of 
the case law at the second stage indicates that, after $W W F$, this distinction has never been the basis for an annulment of a refusal because it is not easy to tell whether a document concerns only the interest of the public or that of the institutions. Some documents, such as those relating to Community legislation, court proceedings, and public policies concern the interests of both the public and the two institutions. Thus, the two institutions could invoke one or more exceptions in the first, second, or both categories. This distinction was established by the CFI in $W W F$ to prevent the Commission from invoking the two categories in a general way, but it has proved to be of little use. The two institutions remained entitled to make their choice because most documents concerned the interests of both the general public and the institutions.

\subsubsection{Certain exceptions not invoked}

The mandatory exceptions in the Code of Conduct and Decision 93/731, contained the public interest exceptions and four other exceptions intended to secure interests relating to privacy, commercial secrecy, and the EC's financial interests. The refusals in the case law at the second stage, however, did not concern these exceptions.

\subsubsection{Access to Second and Third Pillar documents}

The Code of Conduct, a common agreement between the Council and Commission, and the corresponding Council and Commission decisions, merely covered these two institutions. The three measures did not apply to the other Community institutions and bodies or expressly to information relating to the Second and Third Pillars. 
What was initially controversial was whether these three instruments applied to Second and Third Pillar information held by the two EC institutions. Most FOI disputes in the second stage concerned documents produced by either the Council or Commission, the First Pillar. Two exceptions were the Svenska Journalistförbundet and Hautala cases relating to, inter alia, requests for access to Third and Second Pillar documents held, but not produced, by the Council. In the absence of an express provision in the Code of Conduct and Decision 93/731, it was unclear whether these measures covered documents relating to the two pillars in the Council's possession.

France, which supported the Council in both cases, was particularly concerned about this issue. In Svenska Journalistförbunde, France said that without an express provision Decision 93/731 was not applicable to acts adopted on the basis of Title VI TEU, which contained provisions on police and judicial cooperation in criminal matters. The CFI disagreed and held that "Decision 93/731, in Articles 1(2) and 2(2), expressly provides that it is to apply to all Council documents. Decision 93/731 therefore applies irrespective of the contents of the documents requested". The CFI made an apparent effort to have the Second and Third Pillars documents in the Council's possession covered by Decision 93/731. Later, in Hautala, France acknowledged that Decision 93/731 applied to the Second Pillar documents sought but it challenged the Court's jurisdiction in the case. France said that "where the Council has decided to apply Decision 93/731 to documents falling within Title V, its decisions on access to such documents also come under Title $\mathrm{V}$ and, as such, may not be the subject of an action under Article 173 of the EC Treaty". The CFI did not tackle head on the challenge, saying without elaboration the fact that the report sought came under Title V TEU had no effect on the jurisdiction of the Court. The Court then referred to its Svenska Journalistförbundet judgment, stating that 
Decision 93/731 applied to the Second and Third Pillars documents, an emphasis irrelevant to the Article 173 jurisdiction issue. The Court should have addressed this challenge by examining former Article $173 \mathrm{EC} .{ }^{318}$ This article provides that "[t]he Court of Justice shall review the legality of acts of the Council and the Commission other than recommendations or opinions". The authors of the EC Treaty, who defined reviewable acts by means of a negative definition, merely excluded recommendations and opinions. All the other acts are reviewable, irrespective of their relationships with the First, Second, and Third Pillars.

These judgments indicated that, although the FOI measures did not apply directly to the two pillars, it did not mean that all the Second and Third Pillar information would always be unavailable to the public. This was because the Community courts drew a distinction between those documents relating to the two pillars held by the Council and Commission and those not in their possession. In the Svenska Journalistförbundet and Hautala judgments, the Courts held that Decision 93/731 applied to Third and Second Pillars documents held by the Council. As there was no provision concerning this issue, at least not an express one, such a decision apparently showed the Courts' effort to extend the scope of the right of access.

This endeavour, however, remained insufficient to guarantee effective FOI protection in the Union since the three FOI instruments only covered Council and Commission documents. It bears noting that freedom of information will never be realised in the Union unless the citizens have access to the information held by all the EU institutions, agencies, and bodies, in order to scrutinise the operation of the Union.

${ }^{318}$ See 3.9.3.1. 


\subsubsection{General rules and fundamental rights}

The discussion over the scope of the three FOI measures revealed that the Union urgently needed general rules on the right of access to information. But what does the term "general rules" refer to with regard to EU FOI protection? The Courts never explained what they envisaged these rules to be. It has been argued that the term general rules should be understood as meaning a regulation coupled with an express provision in the EC Treaty. According to Article 249 EC, a regulation "shall have general application. It shall be binding in its entirety and directly applicable in all Member States". This means that a regulation is essentially legislative, setting out general rules binding at both Community and national levels. The characteristics of a regulation, according to Article $249 \mathrm{EC}$, are different from those of directives and decisions, which are only binding on the person or persons to whom they are addressed. In other words, directives and decisions are not generally binding. In addition to the FOI regulation, there was also a need for an express Treaty provision, which, in fact, would act as the basis for the regulation noted above.

In the 1996 Netherlands judgment, the ECJ stated that at Community level the importance of the right of access had been reaffirmed on various occasions, indicating that the Court was fully aware of the significance of this freedom. The Courts, however, did not deliver a revolutionary judgment recognising the right at this second stage. ${ }^{319}$ This was because the status of Declaration 17 to the Maastricht

\footnotetext{
319 Professor Eduardo Chiti also said in 1998 that the Courts "have been neither particularly innovative, especially if compared with national courts, nor have they adopted a consistent line in defining the nature of access to information". E. Chiti, 'Case T-105/95, WWF UK (World Wide Fund for Nature) v. EC Commission, Judgment of the Court of First Instance of 5 March 1997, [1997] ECR II-313' (1998) 35 Common Market Law Review 203. See also C. Harlow, "Freedom of Information and Transparency as Administrative and Constitutional Rights," in A. Dashwood and A. Ward (eds.), Cambridge Yearbook of European Legal Studies vol. 2 (Oxford, Hart Publishing, 2000), 300-301.
} 
Treaty was not at all clear. If the Courts had recognised freedom of information as a fundamental right in the Union, they would have had to elaborate on the nature of this right in their judgments. It should be noted that the Courts, by waiting for future recognition of freedom of information in a revised or future Treaty, must not be regarded as opposing FOI protection. The above mentioned limits set by the Courts to the two categories of exception indicated that the Court had made an effort to elevate freedom of information to a level analogous to a fundamental right, though this endeavour was made under the framework of the Code of Conduct and the corresponding decisions.

\subsubsection{Conclusion}

EU citizens were granted more freedom of information by the Code of Conduct and the two corresponding decisions than they had been given before 1993. The rules in these three legal measures, however, provided the public with only limited freedom of information, which indicated that the leaders within the Council and Commission at that time believed that secrecy should be the rule and openness the exception. However, the Community courts and, in particular the CFI, adopted a contrary stance on this issue, establishing the principle that openness should be the rule and secrecy the exception. The Courts made an obvious effort to extend the right of access through interpreting the exceptions narrowly by reference to Article $253 \mathrm{EC}$ (former Article $190 \mathrm{EC}$ ) and the principle of proportionality. It can be concluded, therefore, that it was the Community courts, rather than the three instruments, that elevated freedom of information almost to the level of a fundamental right. 


\section{PART II}

\section{The Present FOI Regime in the EU: Evolution III (2001 2004)}

The previous chapter addressed major issues concerning the Code of Conduct, and corresponding Council Decision 93/731 and Commission Decision 94/90, as well as the relevant case law. On the one hand, the three legal instruments provided for unprecedented, though limited, protection for freedom of information in the European Union. On the other hand, the Community courts made an overt effort not only to secure implementation of the three measures, but also to extend the protection on a number of occasions through broad interpretations of unclear legal terms. ${ }^{1}$ Nonetheless, as we saw in Chapter 3, the endeavours of the Courts were not always sufficient to defend properly the right of access in the Union. This is mainly because the efforts were made under the legal framework of the three measures noted above, which were adopted by the Council and Commission under Declaration 17 annexed to the Treaty of Maastricht, a non-legally binding statement, rather than a Treaty provision recognising freedom of information as a fundamental right.

Certain disputes concerning this subject, which occurred during the second stage of EU FOI development, indicated that the Union urgently needed "general rules" on freedom of information. These two words, which were repeatedly

\footnotetext{
${ }^{1}$ As in the 1998 Svenska Journalistförbundet and 2001 Hautala judgments. See 3.7, and 3.9. Case T-174/95, Svenska Journalistförbundet v. Council [1998] ECR II-2289, Case T-14/98, Hautala v. Council [1999] ECR II-2489; and Case C-353/99P, Council v. Hautala [2001] ECR I-9565.
} 
employed by the Courts without elaboration, should be regarded as embracing both Treaty provisions and secondary legislation in the form of a regulation, as we saw in 3.3.

Article 1(2) TEU concerns one of the general principles of the Union, providing that " $[t]$ his Treaty marks a new stage in the process of creating an ever closer union among the peoples of Europe, in which decisions are taken as openly as possible and as closely as possible to the citizen" (emphasis added). The italicised words added at Amsterdam placed great emphasis on openness and subsidiarity. Rapid development then followed with an amendment to the EC Treaty by the Amsterdam Treaty in the form of Article 255, which came into force in 1999. In May 2001, the Parliament and the Council adopted Regulation 1049/2001 of 30 May 2001, which marked the beginning of the third stage of the EU FOI evolution. ${ }^{2}$

This part of the study focuses on the changes consequent upon the adoption of Article $255 \mathrm{EC}$, and the 2001 Regulation, the limitations of these provisions, and the related case law. It also considers the extent to which Article $255 \mathrm{EC}$ and the 2001 Regulation have enhanced and could modify further the protection of the right of access in the Union. Article $255 \mathrm{EC}$ came into force in 1999 rather than post 2001, but it is considered more logical to examine the article in this part. This is because it bears little relation to the disputes concerning the three instruments during the second stage considered in Chapter 3 above. Moreover, as the 2001 Regulation was adopted under Article $255 \mathrm{EC}$, it is necessary to address these closely related rules in the same part of this study.

\footnotetext{
${ }^{2}$ Regulation EC 1049/2001 of the European Parliament and the Council of 30 May 2001 regarding public access to European Parliament, Council and Commission Documents [2001] OJ L145/43.
} 


\section{Article 255 EC: Implications and Limitations}

Article 255 EC, which introduced a new Treaty provision on freedom of information, provides that:

1. Any citizen of the Union, and any natural or legal person residing or having its registered office in a Member State, shall have a right of access to European Parliament, Council and Commission documents, subject to the principles and the conditions to be defined in accordance with paragraphs 2 and 3.

2. General principles and limits on grounds of public or private interest governing this right of access to documents shall be determined by the Council, acting in accordance with the procedure referred to in Article 251 within two years of the entry into force of the Treaty of Amsterdam.

3. Each institution referred to above shall elaborate in its own Rules of Procedure specific provisions regarding access to its documents.

These rules are different in many ways from Declaration 17 annexed to the Maastricht Treaty and the Code of Conduct, which constituted the basis for Council Decision 93/731 and Commission Decision 94/90. As regards legal effect, Declaration 17 and the Code of Conduct were non-legally binding, though both of them had indirect legal effect. ${ }^{1}$ The insertion of Article $255 \mathrm{EC}$ has brought about a

\footnotetext{
${ }^{1}$ Declaration 17 undoubtedly has indirect legal effect as it grants the right of access to documents to EU citizens. Some other declarations, such as the Declaration on the Enlargement of the European Union annexed to the Treaty of Nice, have not only indirect legal effect but also constitutional relevance. As to the Code of Conduct, although it was a political agreement between the Council and Commission, it had a normative quality, as we saw in Chapter 3, in particular 3.3.4.1 and 3.5.2.2 C.
} 
revolution in the FOI field since the article acts as the Treaty basis for EU FOI legislation, elevating the status of this right significantly. This study consequently considers the extent to which the article has changed the face of this right.

\subsection{Fundamental issues}

\subsubsection{FOI: now a fundamental right and general principle of law?}

Freedom of Information became a new Treaty-based right following the insertion of Article 255 EC. Is this freedom now a fundamental right in the EU? No one will deny the importance of this issue but few have explained why it is now seen as so central in the Union.

This issue was raised in the case law for the first time in the 1996 Netherlands judgment, in which the Netherlands sought the annulment of, inter alia, Decision 93/731. ${ }^{2}$ In his opinion, Advocate General Tesauro said it might be considered to be increasingly clear that the right of access to information was a fundamental civil right. ${ }^{3}$ The ECJ, which did not touch upon this issue, said as there were no "general rules" on freedom of information at that time, the Council and Commission must take their own measures addressing this right. The ECJ, therefore, dismissed the

This is mainly because the institutions saw the Code of Conduct as obliging them to adopt the two corresponding decisions, and the Courts on a number of occasions applied the Code of Conduct as if it were legally binding.

${ }^{2}$ Case C-58/94, Netherlands v. Council [1996] ECR I-2169.

${ }^{3}$ Opinion, at point 16. However, as we have seen in 3.3.2, Mr. Tesauro proposed that the ECJ should declare the application inadmissible mainly because the Code of Conduct was an "agreement essentially of a policy nature". Opinion, at points 23 and 25 . 
Dutch government's application. Article 255 EC, a Treaty provision, is undoubtedly part of the so-called "general rules", which was designed to bring to an end the days of full institutional discretion of FOI rules. However, if freedom of information remains a non-fundamental right, the two institutions could still claim that the general interest in good administration prevails over freedom of information, particularly, when considering requests for access to information in their possession. ${ }^{4}$

In dealing with this issue, we must look seriously at the place of Article 255 in the EC Treaty. It can be found in Chapter 2 of Part V EC, entitled "Provisions Common to Several Institutions". Article 255 EC, which concerns a right of increasing importance, does not, therefore, emerge from that section of the EC Treaty which addresses citizenship of the Union or the general principles of the Union. The Netherlands was the first Member State to demonstrate serious interest in freedom of information in the Community. ${ }^{5}$ At Maastricht, the Dutch delegation proposed to amend Article 213 EC (now Article 284 EC) to establish competence for the Council to adopt a FOI regulation. ${ }^{6}$ The Netherlands at that time sought to stress that the FOI issue was not so much a matter of the internal working procedures of the institutions, but rather that of the public's right to information. There was, however, only a consolation prize for the Netherlands: Declaration 17 to the Maastricht Treaty.

At the Amsterdam Intergovernmental Conference, the Netherlands attempted to include a public access provision in Part II of the EC Treaty which concerns

\footnotetext{
${ }^{4}$ Dr. Ulf Öberg expressed similar concern in 2000. In addition, he said this narrow legal basis provided for in Article $255 \mathrm{EC}$ could discourage any serious attempts from the EC legislature to initiate a constitutional reform. U. Öberg, "EU Citizens' Right to Know: the Improbable Adoption of a European Freedom of Information Act," in A. Dashwood and A. Ward (eds.), Cambridge Yearbook of European Legal Studies vol. 2 (Oxford, Hart Publishing, 2000), 324 and 328.

${ }^{5}$ See 2.4 .

${ }^{6}$ Former Article 213 EC states that " $[t]$ he Commission may, within the limits and under conditions laid down by the Council in accordance with the provisions of this Treaty, collect any information and carry out any checks required for the performance of the tasks entrusted to it".
} 
Citizenship of the Union, on an equal footing with the other rights conferred on EU citizens. This effort, however, appeared to "have fallen on deaf ears, including those of Member States with claims of a constitutional heritage of public access to official documents". ${ }^{7}$ Article $255 \mathrm{EC}$, as a result, was inserted in the part entitled "Provisions Common to Several Institutions". It bears noting, first, that the decision to place the right in the current section could reasonably be interpreted as indicating an intention to deny the fundamental status of the individual's right of access to information. In practice, the Community court does not understand this article in this way, but the three institutions, in particular the Council, could attempt to take advantage of the interpretation by arguing that this freedom does not prevail over fundamental rights or other non-fundamental rights. Second, this position also indicates that the legal instrument to be adopted will not cover the information of all the EC institutions and bodies, which is the issue we will go on to address in the next section.

\subsubsection{Which bodies are covered by Article 255 EC?}

The Code of Conduct and the two corresponding Council and Commission decisions merely covered the documents in the possession of the two institutions. As to public scrutiny, under the legal framework of the three instruments, the public was thus able to scrutinise the EC executive and part of its legislative operation through access to the documents held by the two institutions. Article $255 \mathrm{EC}$, which grants the public a

\footnotetext{
${ }^{7}$ U. Öberg, 'Public Access to Documents after the Entry into Force of the Amsterdam Treaty: Much Ado about Nothing?' (1998) European Integration Online Papers Vol. 2, n. 8, 12-13, http://eiop.or.at/eiop/texte/1998-008.htm
} 
right to obtain information held by all the three major EC institutions, therefore covers the full executive and legislative functions of the Community. This change, however, does not in practice constitute significant progress, as the Parliament has a respectable record as to transparent decision making. A serious point here, however, is that Article $255 \mathrm{EC}$, just as the Code of Conduct, does not include many other key institutions and bodies in the Union, some of which have encountered problems of openness, such as the European Central Bank (ECB). The formulation of Article 255 $\mathrm{EC}$, however, indicates that the authors of this article did not plan to make the ECB documents available to the public. It bears noting that analogous domestic specialised organisations are typically included under national FOI law. For instance, documents available to the Swedish public are those held, received or drawn up by any public authority, according to Article 3 of Chapter 2 of the 1949 Freedom of the Press Act, one of the four fundamental laws which made up the Constitution of Sweden. $^{8}$

\subsubsection{Beneficiaries}

As regards the beneficiaries of the right of access set out in Article $255 \mathrm{EC}$, the following points are of particular interest. First, Article $255 \mathrm{EC}$ states that freedom of information is not only available to EU citizens, but also to "any natural or legal person residing or having its registered office in a Member State". This rule concerning beneficiaries is much clearer than that in the Code of Conduct, which

\footnotetext{
${ }^{8}$ The three others are the 1974 Instrument of Government, the 1810 Act of Succession, and the 1991 Fundamental Law on Freedom of Expression. The English translation of this Constitution is available at the Swedish government website: http://www.sweden.gov.se
} 
only provided that "the public" shall have access to documents held by the Commission and Council. The Code of Conduct neither elaborated on whether "the public" referred only to EU citizens, nor did it explicitly exclude "natural and legal person residing or having its registered office in a Member State" from protection. ${ }^{9}$

Second, Article $255 \mathrm{EC}$ indicates that those who are neither EU citizens nor reside or have a registered office in a Member State have no right to access the information held by the Union, even in the circumstances where EU policies or EU law have a direct impact on them. In reality, this may not be the case. Those who do enjoy the right are entitled to help make a request on behalf of those who do not. The point here is that if those who are not granted this right under Article $255 \mathrm{EC}$ are not prohibited from asking for assistance by those who have this right, the ground for preserving this freedom for the named group of beneficiaries is shaky. From the U.S. point of view, the European provision is not generous enough. As Professor Amanda Frost has said, "[s]ymbolically, ... the limitation serves to carve out a special privilege reserved for EU members and citizens, perhaps with the intention of enhancing a sense of European citizenship and community". ${ }^{10}$

It is important to note in this respect that, Article $255 \mathrm{EC}$ does not require the beneficiaries to demonstrate a reason when making an application for access to information. This is a principle that has been repeatedly affirmed in the case law.

\footnotetext{
${ }^{9}$ Professor Deirdre Curtin has said that "the Treaty of Amsterdam generously extended the right of information beyond 'EU citizens' to 'any natural or legal person residing or having its registered office in a Member State'. D. Curtin, 'Citizens' Fundamental Right of Access to EU Information: an Evolving Digital Passepartout?' (2000) 37 Common Market Law Review 9-10. We doubt, however, whether this view is correct. The Code of Conduct and the two corresponding Council and Commission decisions did not state, at least not in an explicit manner, that only EU citizens were entitled to enjoy this right.

${ }^{10}$ A. Frost, 'Restoring Faith in Government: Transparency Reform in the United States and the European Union' (2003) 9 European Public Law 96. She points out that this is one of the ways that Article $255 \mathrm{EC}$ differs from the U.S. Freedom of Information Act, as the latter "can be used by any individual, regardless of citizenship or country of residence".
} 


\subsubsection{The implementing legislation}

Article 255(1) EC provides that the principles and conditions of the new legislation shall be defined according to Article 255(2) and 255(3) EC. It should be noted that these provisions, which concern the implementation of the future legislation and corresponding procedural rules, leave the Commission, the Parliament, and the Council considerable space to propose and adopt the new rules. Article 255(2) EC states that the Council and Parliament are entitled to decide on new "general principles and limits on grounds of public or private interest", according to the procedure referred to in Article 251 EC. ${ }^{11}$ This procedure is more democratic than that set out in the Code of Conduct, which allowed the Council and Commission to adopt severally their decisions on freedom of information without any requirement that they consider the opinion of the Parliament. Under Article 255(2) EC, the requirement that co-decision procedure be used marks the end of the days during which the Council and Commission enjoyed full discretion when taking steps to realise the limited freedom of information of the European public.

The implementation procedure laid down in Article 255 EC undeniably demonstrates more respect for the Parliament, but it bears noting that this article remains insufficient to prevent the Council and Parliament from adopting rules similar to those in the Code of Conduct and the two corresponding decisions. ${ }^{12}$

\footnotetext{
${ }^{11}$ Article $251 \mathrm{EC}$ (ex Article 189b EC), which sets out the so-called "co-decision procedure" or "joint legislative procedure", was incorporated into the EC Treaty by the TEU and modified by the Treaty of Amsterdam. This procedure refers to that for legislation adopted jointly by the Parliament and Council.

${ }^{12}$ Mrs. Sionaidh Douglas-Scott has been particularly concerned about the possibility that the institutions could abuse their power in adopting broad exceptions to openness. She has said Article 255(2) EC leaves quite a lot of scope for exceptions "on grounds of public or private interest" in its implementation. S. Douglas-Scott, Constitutional Law of the European Union (Essex, Longman, 2002), 146.
} 
Attention should be drawn to the actions to be taken by the Council, as the EU FOI history shows that it has made every attempt not to realise the right of access. Things could get even worse, in that Article $255 \mathrm{EC}$ is incapable of preventing the adoption of a legal instrument which is more conservative than the previous framework. To put it differently, if the Commission, the Council, or the Parliament, or all of them, abuse the authority granted by Article $255 \mathrm{EC}$ in adoption of the new principles and conditions, the future legislation could become very analogous to Decision 93/731, of which the Netherlands sought annulment in the 1996 Netherlands case. ${ }^{13}$

Professor Deirdre Curtin expressed serious concern over the danger that could arise with the interpretation of Article 255 EC in 2000, a year before the new Regulation was adopted. She said that "the presumption must be that every EU citizen and every third country national resident in a Member State of the Union (as pursuant to the terms of Article 255(1)) has the right of access to the documents of the three named institutions". 14 She stressed that "no supplementary grounds can be raised by the institutions as grounds for refusing citizens' access to documents. Either the grounds of refusal are explicitly mentioned in the text of the legal instrument to be adopted or they are of no relevance". ${ }^{15}$

\subsubsection{Conclusion}

The place of Article 255 in the EC Treaty indicates that the authors of this provision

\footnotetext{
${ }^{13}$ n. 2 above.

14 Curtin, n. 9 above, at 15.

15 She has also said that the "presumption will always be that the citizen enjoys the right of access to the documents in question and the burden of proof is placed squarely on the respective institutions to rebut that presumption in a satisfactory manner and in accordance with the explicit indications contained in the section of the legal instrument establishing the limits of the general principle of access". Curtin, n. 9 above, at 15-16. Dr. Ulf Öberg also said in 2000 that the Parliament should restore the Union's credibility with its citizens "by providing them with a legally enforceable 'Right to Know', subject to clear and exhaustive exceptions" (emphasis added). Öberg, n. 4 above, at 327-328.
} 
did not intend to elevate freedom of information to the status of a fundamental right in the Union. Nonetheless, we should not jump to the conclusion that this freedom would not be protected as a fundamental right or regarded as a general principle of Community law. We must go on to examine the 2001 Regulation and the views of the Community courts in relevant disputes before we can better understand the status of this freedom in practice in the Union.

\subsection{Obstacles to the implementation of Article 255 EC}

Article $255 \mathrm{EC}$ provides an imperfect guarantee of freedom of information mainly because it states in its first paragraph that the new legislation on access to documents is restricted to the Council, the Commission, and the Parliament, rather than be applicable to all the EC institutions and bodies. ${ }^{16}$ Although EU citizens are now entitled to access information relating to the Second and Third Pillars held by the three EC institutions, they are not allowed to put the Second and Third Pillars under FOI-based public scrutiny in a direct and effective manner. It is, however, undeniable that the insertion of Article $255 \mathrm{EC}$ by the Treaty of Amsterdam marked a new stage in the development of this field. Freedom of information in the Union has since then been protected through a Treaty provision, rather than a non-legally binding measure, i.e. Declaration 17 annexed to the Maastricht Treaty. The point here is, therefore, whether this new provision assures instant and proper protection of this right.

${ }^{16}$ See 4.1.2. 
Article 255(2) EC states that "[g]eneral principles and limits on grounds of public or private interest governing this right of access to documents shall be determined by the Council, acting in accordance with the procedure referred to in Article $251 \mathrm{EC}$ within two years of the entry into force of the Treaty of Amsterdam". As previously noted, this provision introduces the co-decision procedure to the legislative process of the new FOI rules, indicating that the Council and Commission would not be entitled to decide on their rules severally. What we saw in 2000, however, was not a linear development but deliberate attempts by the Commission and Council to resist the implementation of Article 255 EC. This study analyses the institutions' reluctance to accelerate the reforms in this field, concentrating on the lessons that can be learned through an examination of the Commission's proposal for new legislation and two relevant Council decisions adopted in 2000.

\subsubsection{The Commission draft legislation}

The Commission released its proposal for a new Regulation on 26 January 2000 and a revised edition three weeks later. ${ }^{17}$ This draft was far from satisfactory mainly because the list of exceptions to openness set out in Article 4 of the proposal was much longer than that in the Code of Conduct. In addition, additional exceptions were found in other provisions. Article 2 of this draft is an example. With respect to the scope of the draft Regulation, Article 2(1) stated that "[t]his Regulation shall apply to all documents held by the institutions, that is to say, documents drawn up by

\footnotetext{
${ }^{17}$ Proposal for a Regulation of the European Parliament and of the Council regarding public access to European Parliament, Council and Commission documents, COM/2000/0030 final - COD 2000/0032 [2000] OJ C177 E.
} 
them or received from third parties and in their possession", which was consistent with the obligation laid down by Article 255(1) EC. This provision was, however, followed by a rule of considerable controversy, which provided that "[a]ccess to documents from third parties shall be limited to those sent to the institution after the date on which this Regulation becomes applicable". Article 2(2) provided that "[t]his Regulation shall not apply to documents already published or accessible to the public by other means. It shall not apply where specific rules on access to documents exist". This was another example indicating that exceptions to openness in the Commission draft could be found not only in Article 4 of the proposal, entitled "Exceptions", but other parts of it. As a result, it was not surprising that the document elicited serious concerns and harsh criticism by the European Ombudsman, the Member States, and commentators. In addition, the draft also led to a bitter dispute between the Council and Parliament. ${ }^{18}$

The Ombudsman, who played a pivotal role in challenging the excessive secrecy of the Commission proposal, was very critical of this proposal. ${ }^{19}$ Mr. Jacob Söderman stated that "rights are worth nothing without effective remedies, giving as an illustration the constitutional right of access to documents of the European Parliament, Council and Commission promised in the Amsterdam Treaty". ${ }^{20} \mathrm{He}$ also

\footnotetext{
${ }_{18}$ P. Birkinshaw, European Public Law (London, Butterworths, 2003), 275.

19 In addition to the Ombudsman, a number of the Member States also made constructive criticism on the Commission proposal. The U.K. House of Lords Select Committee on the European Union, for instance, reported on the draft. This is a valuable document because the Committee not only commented on the draft, but also touched on the key weakness of Article $255 \mathrm{EC}$. In paragraph 178 of this report, the Committee states that "limiting that right to EU citizens and residents and imposing duties on only three institutions, though consistent with Article $255 \mathrm{EC}$, is in principle undesirable and may give rise to artificial distinctions, if not unfair discrimination, in practice. The opportunity should be taken, in so far as the Treaty permits, to extend the scope of the Regulation". The House of Lords Select Committee on the European Union, HL Report of the Select Committee on European Union: Public Access to EU Documents (HL Report (2000) No 16). The full text is available at: http://www.parliament.the-stationery-office.co.uk/pa/ld199900/ldselect/ldeucom/102/10205.htm

${ }^{20}$ He made the remarks on 2 February 2000, according to a press release issued by the Ombdusman after the draft Regulation was released. The Ombudsman, Ombudsman Calls for a Fundamental Right
} 
stated that "I am sorry to say that this document seems to consist mainly of a long and obscure list of possible reasons to deny access to documents. This cannot be what was intended when the Treaty of Amsterdam was drafted". ${ }^{21}$

The Commission proposal did not deserve such harsh comment since it brought some benefits to the EU, though Mr. Söderman's view did highlight the major weakness of this draft, namely too many obscure exceptions to openness. Certain advances on the previous FOI regime could be discovered in the draft. For instance, the Commission removed the authorship rule in the proposal, and acknowledged the right to partial access to documents and the duty to maintain registers. ${ }^{22}$ The U.K. House of Lords Select Committee on the European Union said these proposed changes were "all positive steps forward". ${ }^{23}$ It stated in a report that "[a]bove all, the Regulation should recognise explicitly the concept of a fair balance between competing or conflicting interests: on the one hand, the individual's right to the widest possible access to documents and, on the other, the public or private interests which may be harmed by disclosure". ${ }^{24}$ Both the Committee and the Ombudsman were very concerned about the unnecessary exceptions that could constitute impediments to implementation of Article $255 \mathrm{EC}$.

\subsubsection{The first Solana decision}

Things became difficult in the summer of 2000 amidst bitter debates over the

to an Open, Accountable and Service-Minded Administration Press Release 3/2000 (02 February 2000), http://www.euro-ombudsman.eu.int/release/en/charter1.htm

${ }^{21}$ Ibid.

${ }^{22}$ The authorship rule refers to Section 2, paragraph 3 of the Code of Conduct, which provides that "[w]here the document held by an institution was written by a natural or legal person, a Member State, another Community institution or body or any other national or international body, the application must be sent direct to the author".

${ }^{23}$ para. 178 of the House of Lords Select Committee on the EU report, n. 19 above.

${ }^{24}$ para. 179, n. 19 above. 
Commission proposal. On 27 July, when Europe was on holiday, the Council took a very controversial step further to protect the Second Pillar information, i.e. the documents concerning the common foreign and security policy. It amended Decision 24/95 of the Secretary-General on measures for the protection of classified information applicable to the General Secretariat of the Council with regard to the grades of classification. ${ }^{25}$ This is the so-called "Solana decision", named after Mr. Javier Solana, Secretary-General of the Council and High Representative for the Common Foreign and Security Policy, who seemed to have masterminded the action. $^{26}$ The Council adopted the measure pursuant to the second paragraph of Article 23(2) of the Council's Rules of Procedure of 5 June 2000 (no longer in force), claiming that "the Secretary-General shall take all the measures necessary to ensure the smooth running of the General Secretariat". 27

The Council adopted the decision in the context where the Union was developing its defence structures, which require close cooperation with NATO and its strict security procedures. ${ }^{28}$ However, as regards its special treatment of the Second Pillar information, Article 2(1) of the Decision indicates the "bad faith" of those who took the decision. Article 2(1) stated that there were four categories of information:

\footnotetext{
${ }^{25}$ Decision of the Secretary-General of the Council/High Representative for the Common Foreign and Security Policy of 27 July 2000 on measures for the protection of classified information applicable to the General Secretariat of the Council [2000] OJ C239/01.

${ }_{26}$ The appointment of Mr. Solana, an experienced politician, in 1999 marked a departure from the tradition of appointing a diplomat to head the Secretariat-General of the Council, and bore witness to the changed role of the Secretary-General. F. Hayes-Renshaw, 'The Council of Ministers' in J. Peterson and M. Shackleton (eds.), The Institutions of the European Union (Oxford, Oxford University Press, 2002), 52. The structure of the Secretariat was altered towards the end of the 1990s to implement some of provisions of the Treaty of Amsterdam, which added the role of High Representative for the Common Foreign and Security Policy to that of the Secretary-General.

${ }^{27}$ Preamble of the Council decision. n. 25 above. The second paragraph of Article 23(2) of the Council's Rules of Procedure provides that "[u]nder its authority the Secretary-General and the Deputy Secretary-General shall take all the measures necessary to ensure the smooth running of the General Secretariat". Council Decision of 5 June 2000 adopting the Council's Rules of Procedure, 2000/396/EC, ECSC, Euratom [2000] OJ L149/21.

${ }^{28}$ I. Black, 'Fury as envoys vote for military secrecy', The Guardian (Manchester the UK 27 July 2000), http://www.guardian.co.uk/international/story/0,3604,347451,00.html
} 
top secret, secret, confidential, and restricted. Interpreting the phrase "classified information" in the broadest sense, the Council was entitled under this provision to make almost all the General Secretariat's documents classified ones. The information which did not fall within the first three categories could be regarded as restricted information if the Council intended to do so. This is because a document is viewed as restricted as long as the unauthorised disclosure of it would be "inappropriate or premature", according to Article 2(1)(d). The long list of classified information constituted an apparent obstacle to the implementation of Article $255 \mathrm{EC}$ and contradicted the principle of "widest possible access" set out in the Code of Conduct.

The adoption of the Council decision led immediately to furious protests. ${ }^{29}$ Fortunately, this Council decision did not result in substantial destruction of the FOI protection in the Union for the reasons that, first, the new decision was applicable only to the Secretariat General of the Council, rather than the whole institution, and, second, it ceased to be in force soon after adoption of the 2001 Regulation.

\subsubsection{The second Solana decision}

The Guardian reported that Mr. Solana adopted the decision in July 2000 to block not only military documents but also documents about non-military crisis management activities, such as the proposed EU police force to operate after a Kosovo-type conflict. ${ }^{30}$ Nevertheless, the Council decision in fact did not go that far,

\footnotetext{
${ }^{29}$ Heidi Hautala, the Finnish co-president of the Green group in the Parliament, said on 27 July 2000 that "Solana is trying to introduce Nato's secretive methods into the EU through the backdoor". The Netherlands, Finland, and Sweden voted against the plan. One official involved protested furiously that it amounted to a "military coup", ibid.

${ }^{30}$ Black, n. 28 above. The Guardian said in the report that it was also feared that the ban might be
} 
because the first decision only introduced a stricter classification system of the Secretariat General's information, without causing significant damage to the FOI regime in the Union. It was difficult to assess the extent to which the Council would make use of the new classification mechanism, until the institution went one step further on 14 August 2000, amending Council Decision 93/731. ${ }^{31}$ The institution made the amendment in reliance on, inter alia, Article 10 of the Council's Rules of Procedure, which provides that "[t]he detailed arrangements for public access to Council documents was to be adopted by the Council". Article 1(4) of this Decision stated that the first indent of Decision 93/731's Article 4(1) was to be replaced by the following: "- the protection of the public interest (public security, the security and defence of the Union or of one or more of its Member States, military or non-military crisis management, international relations, monetary stability, court proceedings, inspections and investigations)" (emphasis added). The italicised words were added by the amending Council decision. What was worse, the public register of Council documents would, according to Article 2(1), no longer contain reference to top secret, secret and confidential documents "on matters concerning the security and defence of the Union or of one or more of its Member States or on military or non-military crisis management". In brief, not only access to those documents could be denied, but their existence might not even enter on the public register of the Council.

Fortunately, EU citizens did not have to see the extent to which their freedom of information would be infringed by the two Council decisions, in particular by the second, because the Parliament, whose views prevailed over the Commission

extended to sensitive areas such as police and judicial cooperation.

31 Council Decision of 14 August 2000 amending Decision 93/731/EC on public access to Council documents and Council Decision 2000/23/EC on the improvement of information on the Council's legislative activities and the public register of Council documents [2000] OJ L212/9. 
proposal, adopted Regulation 1049/2001 jointly with the Council in May 2001.

\subsubsection{The access issue: an internal matter?}

The actions above jeopardised not only the commitment to FOI protection made by Article 255 EC but also the framework under the Code of Conduct. First of all, the Council made these attempts to alter, if not to bring about the destruction of, the framework under the Code of Conduct and the corresponding Council and Commission decisions, when Europe was on holiday. These actions show the Council planned to escape public scrutiny. Academic commentators noticed the obvious bad faith of the Council in adopting the two decisions in such controversial circumstances. $^{32}$ Secondly, the adoption of these decisions evidenced that the Council tried to make the most of its authority regarding internal organisation to resist the EU FOI regime under the Code of Conduct, because the institution might soon have to face much stricter rules that could be introduced by the new Regulation. This is presumably why the House of Lords described that action as a "summertime coup".33

All the criticism of the Solana decisions, the Commission proposal for the new Regulation, and the debates over these documents, are presumably of historical

\footnotetext{
${ }^{32}$ Mrs. Sionaidh Douglas-Scott, for instance, said that the "apparent act of bad faith on the Council's part (decided on a 12:3 majority vote) certainly seemed to make it more difficult to fulfill the obligations under Article 255". Douglas-Scott, n. 12 above, at 147.

${ }^{33}$ The House of Lords Select Committee on the European Union, HL Report of the Select Committee on European Union: Public Access to Documents: The Council Decision of 14 August 2000 (HL Report (2001) No 8). The full text of this report is available at: http://www.parliament.the-stationery-office.co.uk/pa/ld200001/ldselect/ldeucom/31/3101.htm This Committee, according to the report, also said that "[w]hile there may be little disagreement that highly classified defence and military documents should not be publicly available, the suddenness and the timing of the adoption of the Decision were, and remain, controversial".
} 
interest now. This study will not go into the details of the two controversial Council decisions above as these measures, which are no longer in force following the adoption of the new Regulation in 2001, had little influence on the Union. What really matters is: what can be learned through examination of these disputes? To answer this we must take a look at the procedures on which adoption of these rules relied.

The disputes discussed above were furious, but few noticed an important distinction here. The people who harshly criticised the two Solana decisions had no choice but, bitterly, to accept them, while those who commented on the Commission draft did not have to accept it, and they eventually won a victory, i.e. the 2001 Regulation. Why was this so? The main reason stemmed from a change of legislative procedures. Before the Treaty of Amsterdam came into force in 1999, FOI issues were addressed under the Council's authority for its internal organisation under the legal framework established by the Code of Conduct. However, after this Treaty came into force, FOI legislation had to be adopted under the co-decision procedure set out in Article 251 EC. It is then necessary to analyse the procedural rules to understand their impact on the EU FOI regime. The adoption of these decisions indicates not only the controversial intention of those who adopted the measures, but also the inappropriateness, if not illegality, of the Council discretion in adopting FOI rules under its procedures.

In Netherlands v. Council in 1996, the Netherlands sought annulment of, inter alia, Article 22 of the Council's Rules of Procedure of 6 December 1993, on the basis that "the purpose of the provision greatly exceeded the confines of the rules 
governing the internal organisation of the Council". ${ }^{34}$ The ECJ did not uphold the argument of the Netherlands since "the measures in question are among those which, as Community law stands at present, an institution is empowered to take pursuant to its power of internal organisation". ${ }^{35}$ The Council adopted the first Solana decision pursuant to the second paragraph of Article 23(2) of the Council's Rules of Procedure of 5 June 2000, by which "the Secretary-General shall take all the measures necessary to ensure the smooth running of the General Secretariat". The second Solana decision was adopted pursuant to Article 10 of the Rules of Procedure of 5 June 2000, entitled "Public access to Council documents", which states that "[t]he detailed arrangements for public access to Council documents shall be adopted by the Council". It is worth noting that this Article is exactly the same as Article 22 of the 1993 version.

A serious point here is that these two decisions had potentially a tremendous impact on the EU citizens' freedom of information, but in the Council's view, issues concerning this imperative freedom, if not a fundamental right, ought to be dealt with pursuant to its power of internal organisation. The result was that the European public had no choice but to accept the two decisions. The 2001 Regulation, however, was adopted according to the co-decision procedure, in which neither the Council nor the Commission had full discretion in determining its content.

Mr. Solana argued that it was necessary to maintain the functioning of the CFSP and to satisfy the EU's NATO partners. ${ }^{36}$ We nonetheless wonder whether he was fully aware of the price the Union might have to pay, which was grave damage to the FOI framework at that time. As to the fundamental difference between the previous

\footnotetext{
34 para. 42 , n. 2 above.

35 para. 43, n. 2 above.

36 Douglas-Scott, n. 12 above, at 146-147.
} 
legal framework and the present approach based on Article $255 \mathrm{EC}$, it bears noting that under the previous system, the institutions could reduce or even deprive EU citizens of their freedom of information, whenever they intended to do so. Thus, it is fair to say that the old regime was extremely hazardous.

The intention demonstrated by the Council in the two decisions was incompatible with the obligation laid down by Article $255 \mathrm{EC}$. This article expressly states in its first paragraph that "[a]ny citizen of the Union, and any natural or legal person residing or having its registered office in a Member State, shall have a right of access to European Parliament, Council and Commission documents". The Council showed little respect for, if not ignored, this Treaty provision.

The previous framework was based on the Code of Conduct, which was in nature a political agreement between the Council and Commission allowing the institutions to adopt relevant decisions severally. Under this mechanism, freedom of information was considered part of the administrative resources that could be used to please EU citizens in circumstances where the public had lost confidence in the institutions. In other words, the FOI protection was at the mercy of the Council and Commission, to be handed down to EU citizens whenever the two institutions deemed necessary. This kind of protection is very different from that based on Article $255 \mathrm{EC}$, which places great emphasis on the importance of the co-decision procedure. Although the EC Treaty does not recognise this freedom to be a fundamental right, it is at least in the hands of EU citizens represented by the Parliament rather than simply the Council and Commission. In this respect, the protection of this freedom is analogous to that of a fundamental right. 


\section{5}

\section{Regulation EC 1049/2001}

This chapter examines the architecture of the all-important 2001 Regulation. It then concentrates on the Regulation's objectives and the exceptions to openness set out in Article 4. A number of provisions will be analysed in depth later in this chapter when the relevant case law is examined. The 2001 Regulation, whose basic structure is similar to that of the Code of Conduct, has 19 articles. They concern mainly the purposes, beneficiaries, scope of the legislation and exceptions, initial and confirmatory applications, as well as the treatment of sensitive documents, registers of documents, and publication in the Official Journal. With regard to application measures, Article 18(1) provides that "[e]ach institution shall adapt its rules of procedure to the provisions of this Regulation".

We first concentrate on the objectives of the 2001 Regulation. The case law repeatedly emphasised the objective of the Code of Conduct, i.e. to ensure "widest possible access", when addressing the initial disputes in this field. This principle was of crucial importance, particularly when the Community courts determined whether the protection of freedom of information prevailed over other interests, which were not in the Code of Conduct's list of exceptions. ${ }^{1}$ Second, this study examines who are the beneficiaries of the Regulation, entitled to exercise the right of access. Third, it considers the scope of the various exceptions set out in this new legislation. This

\footnotetext{
${ }^{1}$ For instance, protection of "opinions of legal services of the Community institutions concerning particular draft legislation" was not an exception set out in the Code of Conduct.
} 
task is crucial since most of the disputes concerning freedom of information at the second stage of FOI development related to exceptions laid down in the Code of Conduct and it can be anticipated that this will also be the case regarding Regulation $1049 / 2001$.

\subsection{Structure}

\subsubsection{Purposes}

Recital 2 of the Preamble to the 2001 Regulation states that "[o]penness enables citizens to participate more closely in the decision-making process and guarantees that the administration enjoys greater legitimacy and is more effective and more accountable to the citizen in a democratic system". On the one hand, this stated purpose of the legislation, namely to make a contribution towards the democratic system of the Union, can be regarded as the fundamental purpose of this new law. On the other hand, Article 1 entitled "Purpose" provides for practical guidelines for determining whether a refusal of a request for access to information held by the Council, the Commission, or the Parliament is consistent with the principle of democracy. This article states that:

The purpose of this Regulation is:

(a) to define the principles, conditions and limits on grounds of public or private interest governing the right of access to European Parliament, Council and 
Commission (hereinafter referred to as "the institutions") documents provided for in Article 255 of the EC Treaty in such a way as to ensure the widest possible access to documents,

(b) to establish rules ensuring the easiest possible exercise of this right, and

(c) to promote good administrative practice on access to documents.

First of all, the principle of "widest possible access" set out in Article 1(a), which was also laid down in the Code of Conduct, is an essential part of this provision. The case law, as we saw in Chapter 3, has shown that this principle is not only an aspirational statement but also an enforceable rule of law.

Secondly, with respect to application procedures, a principle of "easiest possible exercise" of the right is laid down in Article 1(b). Thirdly, the principle set out in paragraph (c) concerns the purpose promotion of "good administrative practice on access to documents". This could be controversial in that it is unclear how far, if at all, it goes beyond the principle laid down in paragraph (a) which emphasises the importance of "widest possible access". Indeed, under paragraph (c), a refusal could be made on the ground that disclosure of information could jeopardise the "good administrative practice", a term without clear definition.

On adoption of the new legislation, the Parliament and Council regarded implementation of these three purposes as an important objective of this Regulation. It is, therefore, not surprising that Article 17(2) requires that the Commission, at the latest by 31 January 2004, report on "the implementation of the principles of this Regulation and shall make recommendations, including, if appropriate, proposals for the revision of this Regulation and an action programme of measures to be taken by the institutions" (emphasis added). ${ }^{2}$ This provision indicates that the EU legislator

\footnotetext{
2 The Commission adopted this report on 30 January 2004. European Commission, 'Report from the Commission on the Implementation of the principles in EC Regulation No 1049/2001 regarding
} 
made a deliberate effort to ensure that these purposes would not be compromised in the implementation of this new legal framework.

\subsubsection{Beneficiaries}

As regards the beneficiaries of this Regulation, the first three paragraphs of Article 2 provide that:

1. Any citizen of the Union, and any natural or legal person residing or having its registered office in a Member State, has a right of access to documents of the institutions, subject to the principles, conditions and limits defined in this Regulation.

2. The institutions may, subject to the same principles, conditions and limits, grant access to documents to any natural or legal person not residing or not having its registered office in a Member State.

3. This Regulation shall apply to all documents held by an institution, that is to say, documents drawn up or received by it and in its possession, in all areas of activity of the European Union.

First of all, the first paragraph of Article 2 corresponds to Article 255 EC. $^{3}$ The second paragraph states that the three institutions may additionally grant access to any natural or legal person not residing or not having its registered office in a Member State. The point here concerns the extent to which this provision extends the scope of the beneficiaries set out in Article 255 EC. This provision obviously leaves the three institutions to address this issue individually. Pursuant to Article 2(2), the

Public Access to European Parliament, Council and Commission Documents', COM (2004) 45 final (Brussels, 30 Jan. 2004), http://europa.eu.int/eur-lex/en/com/rpt/2004/com2004_0045en01.pdf. This report will be examined at $\mathbf{5 . 8}$.

${ }^{3}$ See 4.1 above. 
institutions might choose to make a decision on a case-by-case basis, or they might amend their Rules of Procedure to extend this right to all natural and legal persons, irrespective of nationality, place of residence, or location of registered office. The Council and Commission took the latter approach, while the Parliament does not expressly adopt either. The amended provisions will be examined in depth at $\mathbf{5 . 2}$ when we concentrate on the implementation of this legislation.

Thirdly, paragraph three states that this Regulation applies to all documents drawn up or received by an institution and its possession in all the EU activities. It should, however, be pointed out that this does not mean that the new legislation "expressly applies to the second and third pillars of the TEU". ${ }^{4}$ This is because Article 1(a) of this Regulation provides that this legislation only governs "the right of access to European Parliament, Council and Commission documents provided for in Article 255 of the EC Treaty".

\subsubsection{The exceptions to openness}

The first two paragraphs of Article 4, entitled "Exceptions", provide that:

1. The institutions shall refuse access to a document where disclosure would undermine the protection of:

(a) the public interest as regards:

- public security,

- defence and military matters,

- international relations,

- the financial, monetary or economic policy of the Community or a Member

\footnotetext{
${ }^{4}$ S. Douglas-Scott, Constitutional Law of the European Union (Essex, Longman, 2002), 147.
} 


\section{State;}

(b) privacy and the integrity of the individual, in particular in accordance with Community legislation regarding the protection of personal data.

2. The institutions shall refuse access to a document where disclosure would undermine the protection of:

- commercial interests of a natural or legal person, including intellectual property,

- court proceedings and legal advice,

- the purpose of inspections, investigations and audits,

unless there is an overriding public interest in disclosure. (emphasis added)

It is necessary to analyse this article from a comparative perspective. Mandatory exceptions of the Code of Conduct were set out in its fourth section, first subsection entitled "exceptions", which provides that the Council and Commission "will refuse access to any document whose disclosure could undermine the protection" of the public interest, of the individual and of privacy, etc. ${ }^{5}$ What followed was the discretionary exception, which states that "they may also refuse access in order to protect the institution's interest in the confidentiality of its proceedings".

With respect to the 2001 Regulation, Professor Patrick Birkinshaw says that the exceptions in the legislation are also of two types: mandatory and discretionary. ${ }^{6}$ The distinction between the two categories seems to be significant because the exceptions set out in Article 4(2) are subject to a condition, i.e. "unless there is an overriding public interest in disclosure". This condition requires the institutions not to refuse a request where there is an overriding public interest in disclosure. This additional requirement expressly puts the burden on the institution to justify an Article 4(2) exception in which the public or private interest is claimed. In other words, Article 4(2) requires a balancing test. This explains why the exceptions set out

\footnotetext{
${ }^{5}$ Emphasis added.

${ }^{6}$ P. Birkinshaw, European Public Law (London, Butterworths, 2003), 279.
} 
in Article 4(1) can be considered mandatory and those in Article 4(2) discretionary. Later in this chapter, we will consider whether an institution bears an analogous burden when invoking the specific exceptions laid down in Article 4(1) and Article 4(2) themselves. This issue is important because the case law considered in Chapter 3 indicated that the requirement to give adequate reasons in Article $253 \mathrm{EC}$ and the principle of proportionality have been employed to prevent overbroad interpretations of the mandatory exceptions in the Code of Conduct. Since the use of these legal principles has required the Council and Commission to consider their refusals seriously, the coercive nature of the mandatory exceptions was lessened. This blurred the distinction between the two categories of mandatory and discretionary exceptions. Thus, we will focus on what potential the Court has to restrict overbroad interpretations of the mandatory exceptions set out in Article 4(1) of the Regulation in the future.

\subsubsection{Openness: a principle or an exception?}

There are two approaches to dealing with a citizen's request for information in possession of an EU institution, as we saw in 3.1.2, which are:

(1) a presumption that the information should be offered to the citizen unless decision-makers within the EU have a good reason not to do so; or

(2) a presumption that the information ought to be kept secret unless the decision-makers decide to release it.

This distinction is of considerable importance when determining whether a legal 
framework of freedom of information can be relied on to scrutinise public authorities. Recital 11 of the preamble of the 2001 Regulation gives a clue as to whether the first or second of the approaches above is adopted in this legislation. This provides that:

In principle, all documents of the institutions should be accessible to the public. However, certain public and private interests should be protected by way of exceptions. The institutions should be entitled to protect their internal consultations and deliberations where necessary to safeguard their ability to carry out their tasks. In assessing the exceptions, the institutions should take account of the principles in Community legislation concerning the protection of personal data, in all areas of Union activities.

This philosophy is mainly realised in the list of exceptions in Article 4 of the Regulation, which helps determine whether openness is the principle, and secrecy the exception in this Regulation. On the one hand, the EU legislator expressly states that "[i]n principle, all documents of the institutions should be accessible to the public", before emphasising the principles of "widest possible access" and "easiest possible access". On the other hand, the legislator says that certain public and private interests should be protected by way of exceptions. As these statements indicate that openness is the principle, and secrecy the exception in the Regulation, it is fair to say that the first of the two approaches noted above is adopted in this legislation. However, we must examine the implementation by the Council, the Commission, and the Parliament, and analyse the relevant judicial disputes before we can decide the extent to which these institutions follow these principles. 


\subsection{Implementation of the 2001 Regulation}

As regards EU FOI protection, we have seen that the 2001 Regulation brought about a number of changes in substantive and procedural rules. To what extent do these changes make it easier in practice for EU citizens to access the information held by the three institutions? In this section, we will concentrate on implementation of the new legislation before we go on to focus on the relevant case law at $\mathbf{5 . 3}$ to $\mathbf{5 . 7}$.

This section examines, in the first place, the three institutions' amended Rules of Procedure, before it establishes whether they have met the requirements set out in Article 17 of the Regulation, i.e. publication of annual reports that address a number of key issues. ${ }^{7}$ Attention is drawn to the Council and Commission's implementation of the legislation, which is much more problematic than that of the Parliament, through analysis of the two institutions' annual reports. Examination of the enforcement of the Regulation aims to determine the controversies which have arisen during the first two years of implementation. This analysis should help, first, to identify major obstacles to realisation of freedom of information under the new legal framework, and second, to indicate the possible direction of future amendments to the Regulation.

\footnotetext{
7 The Council, Council Annual Report on Access to Documents - 2002 (Brussels, the Council, April 2003), http://ue.eu.int/uedocs/cmsUpload/EN-AR-02.pdf; The Council, Council Annual Report on Access to Documents - 2003 (Brussels, the Council, April 2004), http://ue.eu.int/uedocs/cmsUpload/RapAnCons.en03.pdf. European Commission, Report from the Commission on the Application in 2002 of Regulation (EC) No 1049/2001 of the European Parliament and of the Council regarding Public Access to European Parliament, Council and Commission documents, $\operatorname{COM}(2003) 216$ final, (Brussels, European Commission, 29 April 2003), http://europa.eu.int/eur-lex/lex/LexUriServ/site/en/com/2003/com2003_0216en01.pdf; European Commission, Report from the Commission on the Application in 2003 of Regulation (EC) No 1049/2001 of the European Parliament and of the Council regarding Public Access to European Parliament, Council and Commission documents, COM(2004) 347 final, (Brussels, European Commission, 30 April 2004), http://europa.eu.int/eur-lex/lex/LexUriServ/site/en/com/2004/com2004_0347en01.pdf
} 


\subsubsection{Amended Rules of Procedure}

Article $18(1)$ of the 2001 Regulation provides that "[e]ach institution shall adapt its rules of procedure to the provisions of this Regulation. The adaptations shall take effect from 3 December 2001". The Council amended its Rules of Procedure in November 2001, adding Annex Ш entitled "Specific provisions regarding public access to Council documents". 8 This annex became Annex II of the Council's Rules of Procedure since July 2002 in another amendment. ${ }^{9}$ In response to Article 18(1) of the Regulation, the Commission and Parliament also amended their Rules of Procedure in late $2001 .^{10}$ Among these adaptations, the provisions concerning the scope of potential beneficiaries are of considerable importance.

As regards potential beneficiaries, Article 2(1) of the Regulation states that "[a]ny citizen of the Union, and any natural or legal person residing or having its registered office in a Member State, has a right of access to documents of the institutions, subject to the principles, conditions and limits defined in this Regulation", which corresponds to Article 255(1) EC. Article 2(2) of the Regulation provides that " $[\mathrm{t}]$ he institutions may, subject to the same principles, conditions and limits, grant access to documents to any natural or legal person not residing or not having its registered office in a Member State". This provision entitles the Council, the Commission, and the Parliament to make their own decisions on a case-by-case

\footnotetext{
${ }^{8}$ Council Decision of 29 November 2001 amending the Council's Rules of Procedure (01/840/EC) [2001] OJ L313/40.

${ }^{9}$ Council Decision of 22 July 2002 adopting the Council's Rules of Procedure (02/682/EC, Euratom) [2002] OJ L230/7. The Council amended its Rules of Procedure again in March 2004. Council Decision of 22 March 2004 adopting the Council's Rules of Procedure (2004/338/EC, Euratom) [2004] OJ L106/22. Decision 01/840 and Decision 02/682 are therefore no longer in force.

${ }^{10}$ Commission Decision of 5 December 2001 (2001/937/EC, ECSC, Euratom) Amending its Rules of Procedure [2001] OJ L345/94. Bureau Decision on Public Access to European Parliament Documents [2001] OJ C374/01.
} 
basis, or to amend their Rules of Procedure to extend this right to all natural and legal persons, irrespective of nationality, place of residence, or location of registered office. The Council and Commission expressly took the latter approach. The Parliament adopted the former but in practice it does not take a discriminatory approach. ${ }^{11}$

Article 1 of the Council Rules of Procedure's Annex II states that “[a]ny natural or legal person shall have access to Council documents subject to the principles, conditions and limits laid down in Regulation (EC) No 1049/2001 and the specific provisions laid down in this Annex". ${ }^{12}$ As to the Commission's Rules of Procedure, the second paragraph of the annex's Article 1 entitled "Beneficiaries" provides that "[p]ursuant to Article 2(2) of Regulation (EC) No 1049/2001, citizens of third countries not residing in a Member State and legal persons not having their registered in one of the Member States shall enjoy the right of access to Commission documents on the same terms as the beneficiaries referred to in Article 255(1) of the Treaty". ${ }^{13}$ Both institutions, under the provisions above, extended the scope of beneficiaries.

Article 2(2) of the Regulation leaves significant space for the three institutions to decide whether they would additionally grant access to those "not residing or not having its registered office in a Member State". It bears noting that it is this latitude that resulted in the differences in the provisions above. The EU legislator, therefore, should consider amending Article 2(2) of the Regulation to extend the scope of beneficiaries. First, it seems unnecessary to restrict any who are influenced by operation of the Union or merely interested in this organisation from accessing its

\footnotetext{
11 The Commission says the Parliament "has provided for a similar extension of access in its rules of procedure 'where possible"', according to a Commission report. n. 2 above, at 44 .

${ }^{12}$ The Council, n. 9 above.

13 The Commission, n. 10 above.
} 
information. This change will help citizens of third countries better to understand EU policies, though there is a cost in terms of administrative resources. Second, no measure in the Regulation restricts those who enjoy this freedom from helping those who do not gain access to the three institutions' information, which brings into question the need for Article 2(2).

\subsubsection{Overview of the annual reports}

Annual reports published by the Council, the Commission, and the Parliament should address, inter alia, their implementation of the 2001 Regulation, according to Article 17 of the Regulation. Article 17(1) states that "[e]ach institution shall publish annually a report for the preceding year including the number of cases in which the institution refused to grant access to documents, the reasons for such refusals and the number of sensitive documents not recorded in the register".

\subsubsection{The failure of the Parliament}

The Council and Commission published their 2002 and 2003 annual reports in April 2003 and April 2004. ${ }^{14}$ However, it is surprising that the Parliament has failed to do so, at least not in a normal way. According to a Parliament report on freedom of information published in September 2003 (hereinafter "the Parliament September Report"), the Parliament seems to have published its 2002 annual report at an earlier date. ${ }^{15}$ It is, however, extremely difficult for those interested in the 2002 Parliament

\footnotetext{
14 n. 7 above.

${ }^{15}$ The Parliament, Report on Public Access to Parliament, Council and Commission Documents (Implementation of Regulation 1049/2001/EC in the year 2002) (2003/2022(INI)), 11 September 2003,
} 
report to locate it because, in the first place, the report is entitled "Review of the Implementation within the European Parliament of Regulation (EC) 1049/2001", without employing the phrases such as "report" or " 2002 " in its title. Secondly, those who like to read it are unable to access it, unless they follow the application measure set out in the 2001 Regulation to make a formal request to the Parliament. ${ }^{16}$ In other words, the 2002 Parliament report is not directly available at the website of the Parliament register. It is, therefore, very doubtful that the Parliament really published its 2002 FOI report. In addition, the Parliament also failed to publish its 2003 report.

Except for this failure, the Parliament's implementation of the Regulation is less controversial than that of the Council and Commission. As to the rate of access, the Parliament performed much better than the two other institutions. According to the Parliament September Report, the Parliament's access rate was 98.7 percent in 2002. ${ }^{17}$ The weakness revealed by the unpublished 2002 Parliament report has little to do with the exceptions laid down in Article 4 of the Regulation but a failure to produce statistics concerning the various kinds of requests, which is a technical flaw. $^{18}$

\subsubsection{Expected increase of requests}

The number of initial requests made to the Council and Commission doubled during

Final A5-0298/2003, 5, 11, and 17.

${ }^{16}$ The 2002 Parliament report is entitled "Review of the Implementation within the European Parliament of Regulation (EC) 1049/2001", (PE 324.892/BUR), the Parliament, n. 15 above, at 17. According to the Parliament September report, that 2002 Parliament report is available at http://www4.europarl.eu.int/registre/recherche/DemandeDocuments.cfm?langue=EN. The Parliament, n. 15 above, at 5. This website only provides, however, a document request form rather than the 2002 Parliament report.

17 According to the Parliament September Report, there were 637 requests for access to the Parliament information in 2002. In 109 of the cases, the information sought was unavailable. Among the 109 were nine refused by the Parliament pursuant to Article 4 of the Regulation. The Parliament, $n$. 15 above, at 17.

18 The Parliament, n. 15 above, at 17. 
the first year (2002) after the entry into force of the 2001 Regulation. ${ }^{19}$ Compared with 2002, the number of initial requests made to the Council in 2003 climbed by 18.4 percent. $^{20}$ Compared with 2002 , the number of initial requests made to the Commission sharply rose by 53.7 percent. $^{21}$ However, these were not unanticipated increases, owing to publicity surrounding adoption of the new legislation. The number of requested Council documents soared from 8,090 in 2001 to 9,317 in 2002, and to 12,595 in 2003. The number of requested Commission documents increased by more than 3.5 times from 589 in 2001 to 2,150 in 2002, and to 2,931 in 2003 . First, certain factors resulted in these dramatic rises, which will be individually examined later in this section. Second, it should be noted that although the Council received many more requests than the Commission, it does not necessarily mean that the public is more interested in the operation of the Council than that of the Commission. A probable reason behind these figures is that many Commission documents in which the public is interested might have been available at the website of the Commission register.

\subsubsection{Poorly edited reports}

The Council and Commission annual reports address what has been achieved during the first two years after the new Regulation came into effect. Among the achievements were the establishment of the three institutions' registers, whose websites have been frequently consulted, as well as the founding of the

19 The Council received 1,234 applications in 2001 and 2,394 in 2002, according to the 2002 Council report, Part II entitled "Analysis of Requests for Access", n. 7 above. The Commission received 408 initial requests in 1999, 481 in 2000, and 450 in 2001, but 991 in 2002, according to the 2002 Commission report, n. 7 above, at 18 .

20 The Council received 2,394 requests in 2002 and 2,831 in 2003, according to the 2003 Council report. The Council, n. 7 above, at 15 and 39.

${ }_{21}^{21}$ The Commission received 991 requests in 2002 and 1,523 in 2003, according to the 2003 Commission report. The Commission, n. 7 above, at 9 and 17 . 
interinstitutional committee required by Article $15(2)$ of the Regulation. ${ }^{22}$ Representatives of the institutions held three meetings in 2002, at which they discussed certain essential issues concerning enforcement of the Regulation. ${ }^{23}$ In addition, according to the 2002 Commission report, the officials of the institutions responsible for implementation of the Regulation kept in touch regularly to ensure that the Regulation was applied consistently, to share their experience and to identify best practice. ${ }^{24}$ In September 2003, the committee held another meeting, addressing, inter alia, the evaluation of implementation of the Regulation. Nonetheless, it seems that they made little effort at the meetings to work out a common methodology for presenting the annual reports, which may explain why there are a number of problems with these documents.

First of all, it is doubtful whether the institutions have made every effort to share their experiences in implementing the Regulation, because the Council adopted its 2002 report in April 2003 without forwarding it to the Parliament immediately. The Parliament received it in June $2003 .^{25}$ Secondly, the statistics annexed to the 2002 Council report concern implementation between 3 December 2001 and 31 December 2002, but the figures annexed to the 2002 Commission report concern the period starting from 1 January 2002 to 31 December 2002. This difference makes it more difficult to compare the enforcement of the Regulation by the two institutions.

\footnotetext{
${ }^{22}$ Article 15(2) states that "[ $t$ ] he institutions shall establish an interinstitutional committee to examine best practice, address possible conflicts and discuss future developments on public access to documents".

${ }^{23}$ For instance, the representatives decided at their second meeting that a joint information brochure for the public would be published. This brochure was published in 2002. The European Union, Access to European Parliament, Council and Commission Documents, A User's Guide (Luxembourg, Publications Office, 2002). At their third meeting, they exchanged their views on, inter alia, how to deal with extensive or abusive requests.

${ }^{24}$ The Commission, n. 7 above, at 6 .

${ }^{25}$ The Council, according to the Parliament September Report, forwarded its annual report to the Parliament by a letter of 2 June 2003. The Parliament, n. 15 above.
} 
It should be noted that there was no such difference in the 2003 Council and Commission reports. The terms "the reference period" and "the observation period" in both documents refer to the year 2003. Thirdly, as regards readability and accuracy, the 2002 Council report is far from satisfactory as this official document has no reference number, table of contents, or page numbers. In addition, it has a number of serious and minor mistakes. ${ }^{26}$ The 2003 Council report has its table of contents, and page numbers, but this document has no reference number either.

\subsubsection{The Council reports}

The Council published its 2002 report on access to documents in April 2003. ${ }^{27}$ A large proportion of this report details the measures adopted by the Council to meet the requirements in the 2001 Regulation, including, inter alia, amendment of the Council's Rules of Procedure (Article 15 of the Regulation) and the establishment of an interinstitutional committee (Article 16). ${ }^{28}$ This subsection focuses on three key

${ }^{26}$ These mistakes are:

1. Points 1 and 2 of the Annex to the 2002 Council report indicate the number of applications in the reference period was 2,491 , which covered 10,330 documents. Point 6 entitled "Number of Refusals" shows that there were 1,127 refusals, an astonishing figure, because the access rate of the observation period would then be only 55 percent. It is obviously inconsistent with the figure shown in Point 7,89.1 percent. Thanks to the analysis in Part II of the annual report, we have discovered that 1,127 was not the number of refusals but that of documents covered by the refusals. $n$. 7 above.

2. The 2002 Council report has some minor flaws. For example, the Council says at the end of the document's Part I that in 2002, "approximately 900,000 persons logged onto the Internet site of the register and consulted 4,600,000 pages". As it is almost impossible for the register to realise the number of people who visit its website, it is presumably that the website was visited some 900,000 times in 2002. n. 7 above.

3. According to 4.5.1 of the 2003 Commission report at page 11, 36.92 percent of the refusals made by the Commission in 2003 were based on the public interest exception relating to inspections, investigations, and audits. However, according to Point 11 of the Annex to this report at page 23 , the figure is 37.55 percent. $\mathrm{n}$. 7 above.

${ }^{27}$ The Council, n. 7 above.

${ }^{28}$ See 5.2.1 and 5.2.2.3. 
issues and considers whether there is room to improve the current legal framework.

\subsubsection{Exceptions to openness}

As to the exceptions to openness, attention should be drawn to the second parts of the 2002 and 2003 Council reports, both entitled "Analysis of Requests for Access", in particular with regard to the number of refusals and the grounds given by the Council.

The most often requested information during the period starting from 3 December 2001 to 31 December 2002 concerned justice and home affairs (24.5 percent), the internal market (14.5 percent), economic and monetary policy $(10.5$ percent), and external relations and CFSP (8.5 percent). ${ }^{29}$ Out of 10,330 documents sought during this period, the Council decided not to release 1,127 of them. The overall rate of access was thus 89.1 percent. As regards the grounds for refusal invoked when dealing with the initial applications, the most common exception was that of the protection of the decision-making process ( 27.9 percent), followed by the protection of the public interest as regards international relations (24 percent). ${ }^{30}$

According to the 2003 Council report, the interest of the public in the information held by the Council was similar in 2003. The most frequently requested information continued to relate to justice and home affairs (22 percent), the internal market (16.3 percent), external relations and CFSP (9.1 percent), and on economic and monetary policy (9 percent). ${ }^{31}$ The level of access remained stable during the year while the rate was 87.4 percent. ${ }^{32}$ Meanwhile, the protection of the

\footnotetext{
29 Part II of the 2002 Council report, and Point 10 of the annex. The Council, n. 7 above.

${ }^{30}$ Part II of the 2002 Council report, and Point 2, 6, 7, and 11 of the annex. The Council, n. 7 above.

31 The Council, n. 7 above, at 17 and 42.

32 The Council, n. 7 above, at 18 and 39.
} 
decision-making process and that of the public interest relating to international relations were still the most commonly invoked exceptions (31.2 percent and 28.7 percent respectively). ${ }^{33}$ They account for nearly 60 percent of all the refusals in 2003.

\section{A. The most commonly refused requests}

Many must be curious as to whether the most popular categories of information were made publicly available. If not, were requests for these documents refused by the Council through invoking one or more of the most commonly invoked exceptions? A citizen might ask, for instance, whether most, if not all, of the requests for information on external relations were refused to protect the public interest relating to international relations. This question is important since it will help determine which category of information was most inaccessible during the reference periods.

The Council does not, however, answer this question in the two annual reports. These documents, in fact, provide no data concerning the relationship between the most commonly requested documents and the most frequently invoked exceptions. The statistics indicate that information relating to external relations and CFSP was among the four most common categories of information demanded by the public, while the protection of the public interest relating to international relations was one of the two most often invoked exceptions. We, as a result, suspect that most requests for documents relating to external relations and CFSP were refused by the Council to secure the public interest relating to international relations.

Generally, as there must be requests falling within the scope of the exceptions set out in the Regulation, the 2002 refusal rate of 10.1 percent and 200312.6 percent

${ }^{33}$ The Council, n. 7 above, at 19 and 44. 
should not be regarded as astonishing figures. Nonetheless, if most of the citizens interested in the Council's information relating to international relations received only a frustrating reply to their initial applications, the public should consider whether the Council has been systematically refusing such requests, without showing respect to the principles handed down by the Community courts to ensure "widest possible access". Among these principles is the principle of proportionality, which requires that there exists a reasonable relationship between the ends and the means, a rule applied in the Hautala case by the Community courts. ${ }^{34}$ It should be noted that the CFI stated in the judgment that the principle of proportionality required that "derogations remain within the limits of what is appropriate and necessary for achieving the aim in view". ${ }^{35}$ This principle could be applied to restrict effectively the Council's systematic invocation of the international relations exception.

\section{B. Opinions of the Legal Service}

As regards the grounds invoked to reject initial applications, the protection of court proceedings and legal advice was the public interest exception invoked in 12.2 percent of the refusals at the initial stage, according to the 2002 Council report. ${ }^{36}$ In 2003, this exception was invoked in 10.9 percent of the refusals of initial applications. ${ }^{37}$ The Council says in its 2002 report that "documents or parts of documents in which an opinion of the Legal Service on legal questions is reproduced are not made available to the public pursuant to Article 4(2) of the Regulation, unless

\footnotetext{
${ }^{34}$ Case T-14/98, Hautala v. Council [1999] ECR II-2489, and Case C-353/99P, Council v. Hautala [2001] ECR I-9565.

${ }_{35}$ para. 85 of the CFI judgment, n. 34 above.

${ }^{36}$ Part II of the 2002 report and the Annex's Point 11 entitled "Reasons for refusing access: initial applications", n. 7 above.

${ }^{37}$ The Council, n. 7 above, at 21 and 44 .
} 
there is an overriding public interest in disclosure". ${ }^{38}$ It goes on to say that:

The Council feels that this condition is not met by the simple fact that the disclosure of a document containing an opinion of the Legal Service would be in the general interest of transparency of the decision-making process of the Council. The independent advice provided for the Council by the Legal Service allows the Council to ensure that its acts comply with Community law and to further discussion on the legal aspects of a dossier. If the Council were to lose that instrument, the efficiency of its work would be compromised. (emphasis added) ${ }^{39}$

In its 2003 report, the Council reiterated this view and added further that "[t]his is why it is in the public interest that the Council should have available advice that is given totally independently" (emphasis added). ${ }^{40}$ These statements are extremely controversial, as it suggests that the public should be systematically refused information in which the Legal Service's opinion is reproduced.

These statements, first of all, are obviously incompatible with a fundamental principle set out in Recital 11 of the 2001 Regulation, which provides, inter alia, that "[i]n principle, all documents of the institutions should be accessible to the public. However, certain public and private interests should be protected by way of exceptions". The opinion of the Council shows it believes that disclosure of legal advice will definitely have a negative impact on the efficiency of its work. The Council does not, however, elaborate on why to attain the purpose to comply with EC law requires secrecy. In brief, it apparently assumed that information concerning legal opinions should be kept secret unless it decides to release it.

Secondly, as to how it makes this decision, the Council pays no heed to the

\footnotetext{
38 Part II of the 2002 Council report, n. 7 above.

39 Part II of the 2002 Council report, n. 7 above.

40 The Council, n. 7 above, at 22.
} 
balancing test required by Article 4(2) of the Regulation. The Council rightly pointed out that the condition of Article 4(2) is not met by the fact that "the disclosure of a document containing an opinion of the Legal Service would be in the general interest of transparency of the decision-making process of the Council". In its report, however, the Council fails to consider whether there are any overriding public interests that might be brought about by the disclosure of legal advice. Consequently, it did not ponder the relationships between the specific interests and the Council's interest in such a refusal. What the Council emphasised was solely the latter, namely the efficiency of its work. It is doubtful whether the Council is fully aware of what could be the specific overriding public interests. Thus, it would not be surprising if the Council's systematic refusals of requests for access to its Legal Service's opinions trigger bitter legal disputes in the future.

Thirdly, it should be stressed that the legal advice exception must be invoked in a limited fashion. In many circumstances, the Legal Service's opinions are not at all different from those provided by other Council officials. Disclosure of these views might have positive rather than negative influence on the public's confidence in the Union. The Council is correct when saying that "[i]f the Council were to lose that instrument, the efficiency of its work would be compromised", but refusals based on the legal advice exception must be made on a case-by-case basis. In addition, the work of the Legal Service is part of the Council's operation, which in principle should not be given total independence or exempted from public scrutiny.

\subsubsection{Beneficiaries}

The Council and Commission amended their Rules of Procedure to extend this right to all natural and legal persons, irrespective of nationality, place of residence, or 
location of registered office. ${ }^{41}$ The Parliament decided to make its decisions on a case-by-case basis, but in practice it does not take a discriminatory approach.

The Council's implementation of the 2001 Regulation indicates that it has adopted the correct approach. On the one hand, although the extension above has increased the workload of the Council, the extra work is not significantly taxing. According to the 2002 Council report, the statistics about the geographical breakdown of applicants indicate that only 6.5 percent of the applications during the reference period came from four non-Member States - the United States, Norway, Switzerland, and Japan, which may also include those made by the EU citizens staying in these countries. ${ }^{42}$ In 2003 , the data in this sector remains stable, as only 5.3 percent of the requests came from the United States, Norway, Switzerland, Japan, and Russia. ${ }^{43}$ On the other hand, the extension will, in the long run, benefit the Union. According to the 2002 Council report, the data concerning the applicants' professional backgrounds shows that nearly a quarter of the initial applications (23.5 percent) were made by students and researchers in $2002 .{ }^{44}$ In 2003 , the data in this sector is 23.9 percent. ${ }^{45}$ These figures may include the students and researchers residing in non-Member States interested in the operation of the Council. While the five non-Member States from which applicants made requests have close relationships with the Union, it is unnecessary to place any limits on applications from non-EU citizens of these states. The analysis above indicates that it is time to

\footnotetext{
${ }^{41}$ See 5.2.1.

42 The 2002 Council report, Annex I, entitled "Statistics on Public Access to Council Documents for the Period from 3 December 2001 to 31 December 2002", n. 7 above. It should, however, be pointed out that these statistics are those of geographical breakdown of applicants. It is not clear whether the applicants made their applications from the non-Member States are EU citizens.

${ }^{43}$ The Council, n. 7 above, at 41.

${ }^{44}$ Part II of the 2002 Council report and the Annex II, Point 7 entitled "Professional background of applicants", n. 7 above.

${ }_{45}$ The Council, n. 7 above, at 16 and 40.
} 
consider making the extension a provision of the Regulation, setting out a common scope of beneficiaries in this field.

\subsubsection{Sensitive documents}

Issues concerning the treatment of "sensitive documents", as we have seen in 4.2, triggered furious disputes prior to adoption of the 2001 Regulation. Article 9 of the Regulation, therefore, treats such documents in a very cautious manner. Article 9(1), which defines the phrase "sensitive documents", provides that:

Sensitive documents are documents originating from the institutions or the agencies established by them, from Member States, third countries or International Organisations, classified as "TRÈS SECRET/TOP SECRET", "SECRET" or "CONFIDENTIEL" in accordance with the rules of the institution concerned, which protect essential interests of the European Union or of one or more of its Member States in the areas covered by Article 4(1)(a), notably public security, defence and military matters. (emphasis added)

Sensitive documents are different from the other information governed by the Regulation. This is not because that they originate "from the institutions or the agencies established by them, from Member States, third countries or International Organisations". It bears noting that other information held by the three institutions might also originate from exactly the same source. The reason why the EU legislator treats sensitive documents in a particular manner is that they concern extremely essential interests of the Union. The major distinction between the treatment of sensitive documents and that of the others is that "[s]ensitive documents shall be recorded in the register or released only with the consent of the originator", according to Article 17(3) of the Regulation. This means that a number of sensitive 
documents are unavailable to the public and not recorded in the registers of the three institutions.

The legislator gave special treatment to highly sensitive content of this type, but it did not prevent the public from obtaining information concerning the number of such documents not recorded in the registers. Article 17(1) of the Regulation stipulates, inter alia, that the number of sensitive documents not recorded in the three institutions' registers shall be included in their annual reports. According to the 2002 Council report, a total of 12 "SECRET UE" and 238 "CONFIDENTIEL UE" documents originated from the Council or other sources, only 77 of them are recorded by the institution's register. ${ }^{46}$ The number of sensitive documents soared from 250 in 2002 by 63 percent to 399 in 2003, according to the 2003 Council Report. ${ }^{47}$ A total of 17 sensitive documents originating from the Council or other sources were classified "EU SECRET", and 382 "EU CONFIDENTIAL". 48 According to this report, 136 of the "EU CONFIDENTIAL" documents are referred to in the Council register. ${ }^{49}$ Therefore, the number of sensitive documents not recorded in the register sharply increased by 66 percent from 173 to 263 .

More details concerning this category of information, such as essential interests involved and origins of these documents, etc., should also be included in the annual reports. Mere numbers of sensitive documents do very little to help understand how the Council addresses such information. This category of document is given special treatment as it concerns compelling interests of the Union. It remains, however, questionable whether this protection is excessive and incompatible with the principle

\footnotetext{
${ }^{46}$ Last paragraph of Part I of the 2002 Council report. n. 7 above.

47 The Council, n. 7 above, at 11.

48 The Council, n. 7 above, at 11.

49 The Council, n. 7 above, at 11.
} 
of "widest possible access" set out in Article 1 of the Regulation.

\subsubsection{The Commission reports}

Now turning to the Commission reports, this subsection focuses on two contentious issues concerning exceptions to openness and sensitive documents, which might trigger disputes in this area in the near future.

\subsubsection{Refusals}

The access rate of the Council is 89.1 percent, and the refusal rate is, therefore, 10.9 percent, according to the 2002 Council report. The level of refusal remains stable in 2003 when the rate was 12.6 percent. $^{50}$ According to the 2002 Commission report, the refusal rate of the Commission was, however, 33 percent. $^{51}$ The figure for 2003 was 31 percent, according to the 2003 Commission report. ${ }^{52}$ Can we say that the Commission's approach towards requests for access to its information is much more restrictive than that of the Council? The examination of the case law of the second stage of FOI evolution, as we saw in Chapter 3, gave a negative answer to this question, indicating that the Commission was much more open-minded than the Council when addressing requests for access to its information. So what are the factors that attributed to this difference? Additionally, it bears noting that the Commission's refusal rate increased from 20 percent in 1999 to 25 percent in 2000 ,

\footnotetext{
${ }^{50}$ The access rate of the Council shown in the 2003 Council report is 87.4 percent. The Council, n. 7 above, at 18 .

${ }^{51}$ The Commission, n. 7 above, at 13 .

${ }^{52}$ The Commission, n. 7 above, at 10 and 17.
} 
30 percent in 2001, 33 percent in 2002, and then 31 percent in 2003. Does this tendency to increase mean that the Commission has been taking an increasingly harsh approach towards requests for access its documents?

During these five years, an increasing number of requests might have fallen within the scope of exceptions laid down in the Code of Conduct or the 2001 Regulation, which might have resulted in this trend. Secondly, it is also probable that more applicants misinterpreted the scope of their right granted by the rules. But is this really the case? To answer these questions one must look at the exceptions invoked by the Commission when refusing the requests. With regard to the exceptions, the Commission has said in the 2002 report that:

[A key factor] is the increasing number of requests concerning infringement proceedings and cases relating to competition policy. It should be noted that in over a third of cases where access to a document is refused (35.9\%), the decision to refuse disclosure is motivated by the desire to protect the purposes of inspections, investigations and audits. In most cases the requests were made by law firms. The legal appeals clearly confirm this trend. (emphasis added) ${ }^{53}$

This statement concerns one of the most crucial issues in the 2002 and 2003 Commission reports, i.e. the protection of purposes of inspections, investigations, and audits, which are exceptions laid down in Article 4(2) of the Regulation. The Commission expressly said that in 2002 it invoked these exceptions to refuse more than one third of all the initial requests. In 2003, the figure rose to 37.55 percent, according to the 2003 Commission report. ${ }^{54}$

However, what the Commission has not elaborated on in the two reports is, on

53 The Commission, n. 7 above, at 13.

54 The Commission, n. 7 above, at 23 . 
the one hand, what percentage of all initial applications concerned inspections, investigations and audits, and on the other hand, what proportion of all refusals related to infringement proceedings and cases relating to competition policy. The answer to the former question will help determine whether the Commission refused most of the requests involved with inspections, investigations, and audits. The latter issue concerns whether most of those who requested access to the information concerning competition policy were frustrated by the Commission. Unsurprisingly, the Commission did not answer these two important questions presumably because the answers could draw harsh criticism.

One of the tables annexed to the 2002 Commission report, which provides statistics concerning "subject area", indicates that 12.7 percent of the requests in 2002 concerned competition issues. Another table shows that 35.9 percent of the requests made to the Commission in 2002 were refused to protect the "purposes of inspections, investigations and audits". As the Commission has admitted that in 2002 there was an increasing number of requests concerning infringement proceedings and cases relating to competition policy, most of these competition related requests appeared to have been refused on this ground. In this connection, we saw no sign of change in 2003. According to the 2003 Commission report, 13.7 percent of the applications received in 2003 concerned competition policy, and 37.55 percent of the requests made to the Commission during the year were refused for the protection of the "purposes of inspections, investigations and audits". ${ }^{55}$ The Commission remains silent on whether, in 2003, most requests for access to the information concerning competition policy were refused.

As we noted in Chapter 3, the Community courts have emphasised the

55 The Commission, n. 7 above, at 21 and 23 
importance of the principle of proportionality in the EU FOI field. The Commission has not considered whether refusals of this type are proportionate to the interest relating to an inspection, investigation or audit. This is not an easy task because, first, the Commission may have not yet or have just completed one of the above proceedings when it is called upon to decide whether it would grant access. Secondly, for the Commission, what makes this more difficult is that it has to make such a decision before the time limit of one month expires. Thirdly, the Court might have different views on the requirements of the principle of proportionality when disputes about various exceptions come before it. As the Court has made proportionality reviews only in addressing a couple of FOI disputes, it will be very challenging for the Commission to predict how the Court will apply it when protection of the above purposes is involved. All these difficulties might presumably be the reasons why more than one third of the refusals were made under this provision.

Nevertheless, the approach of the Commission is extremely controversial despite the difficulties noted above. This is because, first, the Commission's attitude towards this taxing task is incompatible with the principle of "widest possible access" set out in Article 1 of the Regulation. When the Commission is uncertain about whether the interests of protection of inspections, investigations, and audits prevail over freedom of information, it should grant access to the requested information rather than refuse the requests. The Commission, however, has done just the opposite. This issue has been very contentious, and is one on which we will concentrate on in the following section, which concerns the examination of relevant case law. 


\subsubsection{Sensitive documents}

The Commission states in its 2002 report that "[a]mong the three categories of documents presently covered by the register (the COM, C and SEC series of 2001 and 2002) there are no sensitive documents within the meaning of Article 9(1) of the Regulation". ${ }^{56}$ This is a contentious way to address the requirement about sensitive documents set out in Article 17(1), which requires that an annual report should include, inter alia, "the number of sensitive documents not recorded in the register". The Commission does not meet this requirement.

Under Article 17(3) of the Regulation, certain sensitive documents are not only unavailable to the public but also not recorded in the registers of the three institutions. The point is that the 2002 Commission report does not offer the figure. What the provision demands is that the Commission must provide the number of unrecorded sensitive documents, not just mention whether there are such documents in its register. In its 2003 report, the Commission improves the way it meets the requirements of Article 17, saying that " 25 documents classified "Confidentiel UE' [EU confidential] from the ' $\mathrm{C}$ ' series of documents are not mentioned in the register. The Commission does not keep other sensitive documents which are covered by the register,. ${ }^{57}$

\subsubsection{Conclusion}

Analysis of the three EU institutions' amended Rules of Procedures and annual

\footnotetext{
${ }^{56}$ The Commission, n. 7 above, at 7.

57 The Commission, n. 7 above, at 7.
} 
reports indicates that certain measures must be adopted in the future to help realise the principle of "widest possible access" set out in Article 1 of the 2001 Regulation. First, as it has been unnecessary to place any limits on applications from non-EU citizens, it is time for the EU legislator to consider amending the Regulation to extend freedom of information to all natural and legal persons in an express manner.

Secondly, Article 17 of the Regulation should include a new paragraph requiring that the three institutions provide cross tabulation between categories of requested information and invoked exceptions in their annual FOI reports. This is an indispensable provision, which will prevent the institutions avoiding addressing crucial questions in the documents, such as what proportion of the requests for access to information relating to the EU's external relations and CFSP are refused to protect the public interest relating to international relations. Thirdly, as to the implementation of the Regulation by the Commission, its refusals of access to documents relating to investigations, inspections, and audits, in particular those concerning competition law are very contentious. We will, as a result, concentrate on the relevant case law in the following section. In addition, the principle of proportionality could be applied effectively to prevent the systematic refusals by the Commission and Council.

As to sensitive documents, the Commission fails to meet the requirement to record the number of sensitive documents in its 2002 report, which is set out in Article 17(1). It redresses this failure in its 2003 report. The Council followed the requirement in its 2002 and 2003 reports, but the mere numbers of these specially addressed documents help little to realise the nature of this category of information. What should also be included in future annual reports is further details about these documents, such as the essential interests involved and origins of these documents, 
etc., which could in no way jeopardise essential interests of the Union. Otherwise, the treatment of sensitive documents appears unduly privileged and is incompatible with the principle of "widest possible access" in Article 1 of the Regulation.

Following the detailed examination of the 2002 and 2003 Council and Commission reports on implementation of the 2001 Regulation, it is necessary to consider relevant judgments after the new Regulation came into force in December 2001. Some of the disputes concerned the Code of Conduct and the two Council and Commission decisions, rather than the 2001 Regulation, but the Courts regularly referred to the latter in these judgments, in which the purpose of the Regulation was repeatedly emphasised. ${ }^{58}$ For this reason, these cases have been included in this chapter. As to these cases, we focus on whether similar disputes would be better dealt with under the new legislation. The main issues that have arisen from these disputes are the following:

1. What are the objectives behind the public interest exceptions relating to investigations, inspections, and court proceedings?

2. What are the differences, if any, between the authorship rule set out in the Code of Conduct and the non-disclosure rule in the Regulation?

3. What is the relationship between the principle of proportionality and the exceptions laid down in the 2001 Regulation?

\footnotetext{
${ }^{58}$ For instance, in para. 39 of Case C-41/00, Interporc Im- und Export GmbH v. Commission [2003] ECR I-2125, the ECJ stressed that objective of the 2001 Regulation is "to enable citizens to participate more closely in the decision-making process, to guarantee that the administration enjoys greater legitimacy and is more effective and more accountable to the citizen in a democratic system and to contribute to strengthening the principles of democracy and respect for fundamental rights". This judgment will be analysed in detail in $\mathbf{5 . 5}$.
} 


\subsection{The Petrie case ${ }^{59}$}

This judgment concerned the authorship rule, as well as the public interest exceptions relating to investigations, inspections, and court proceedings, which were set out in the fourth section of the Code of Conduct. The former, according to the Rothmans judgment, constituted an exception in addition to the two categories of mandatory and discretionary exceptions in the fourth section of the Code of Conduct and Article 4 of Council Decision 93/731. ${ }^{60}$ This section considers the major distinction between the authorship rule and the two categories of mandatory and discretionary exceptions. The point is whether the authorship rule is compatible with the principle of widest possible access. As to the public interest exceptions relating to investigations, inspections, and court proceedings, it bears noting that their purpose was unclear. We will consider whether they can be invoked solely to protect the privileges of lawyers and the right to a fair hearing, or whether they can also be relied on to secure an amicable resolution of a dispute before the Court delivers a judgment? In its 1998 van der Wal judgment, the CFI stated that the exception relating to court proceedings enshrined in Commission Decision 94/90 was designed to ensure respect for the right to a fair hearing. ${ }^{61}$ The Court, however, did not strictly follow this stance in the present case. What was worse was that the Court did not examine whether the Commission had applied the principle of proportionality when refusing the request.

59 Case T 191/99, David Petrie, Victoria Jane Primhak, David Verzoni and Others v. Commission [2001] ECR II-3677.

${ }^{60}$ See 3.8.

${ }^{61}$ para. 48 of Case T-83/96, Gerard van der Wal v. Commission [1998] ECR II-545. 


\subsubsection{Facts}

David Petrie and two other natural persons served as lecturers of foreign mother tongue at Italian universities, but the posts were replaced with those of assistants and mother tongue language experts. ${ }^{62}$ In related judgments, the ECJ held that systematic use by Italian universities of fixed-term contracts to meet needs in language education was incompatible with EC law where a similar use of fixed term contracts had not been employed in other areas of teaching. ${ }^{63}$ Notwithstanding the judgments and subsequent reform, the applicants believed that discrimination against former lecturers of foreign mother tongue persisted. ${ }^{64}$ The Commission later opened infringement proceedings under Article $226 \mathrm{EC}$ against Italy before bringing this matter before the ECJ in June $1999 .{ }^{65}$ To examine the documents held by the Commission relating to the infringement procedure, the applicants requested the Commission to offer 16 categories of relevant information, including documents originating from the Italian authorities and those drawn up by the Commission. ${ }^{66}$ The applicants brought this action in August 1999, after the Commission invoked the authorship rule, and the public interest exceptions relating to investigations, inspections, and court proceedings in refusing their initial and confirmative requests. ${ }^{67}$ As to the investigations, the Commission stressed that "[i]nfringement

${ }_{62}^{62}$ para. 12 , n. 59 above.

${ }^{63}$ para. 13 , n. 59 above. The following cases were referred to: Case 33/88, Pilar Allue and Carmel Mary Coonan v. Università degli studi di Venezia [1989] ECR 1591, and Joined cases C-259/91, C-331/91 and C-332/91 Pilar Allue and Carmel Mary Coonan and others v. Università degli studi di Venezia and Università degli studi di Parma [1993] ECR I-4309.

${ }_{64}^{64}$ para. 13, n. 59 above.

${ }_{65}^{65}$ para. 14, n. 59 above.

${ }_{66}^{66}$ para. 15 , n. 59 above.

${ }^{67}$ paras. 16,17 , and 18, n. 59 above. The authorship rule refers to Section 2, paragraph 3 of the Code of Conduct, which provides that "[w]here the document held by an institution was written by a natural or legal person, a Member State, another Community institution or body or any other national or international body, the application must be sent direct to the author". 
investigations call for genuine cooperation and an atmosphere of mutual trust between the Commission and the Member State concerned so as to enable those two parties to open discussions with a view to a rapid resolution of the dispute". ${ }^{68}$ The applicants invoked three pleas in support of their action. The first was based on infringement of Article 255(1) EC and of Article 1(2) TEU, which are the Treaty bases of the 2001 Regulation. ${ }^{69}$ The second related to breach of Commission Decision $94 / 90$, and the third infringement of the requirement of giving adequate reasoning set out in Article $253 \mathrm{EC}^{70}$

\subsubsection{Held}

The CFI said that, as is clear from Van Gend en Loos, "the criteria for deciding whether a Treaty provision is directly applicable are that the rule should be clear and unconditional". ${ }^{71}$ It stated that Article 1(2) TEU "is not clear in the sense required by the case-law cited, [and] Article $255 \mathrm{EC}$ is, by virtue of paragraphs 2 and 3 thereof, not unconditional and that its implementation is dependent on the adoption of subsequent measures". ${ }^{72}$ It rejected the plea, holding that the two provisions were

\footnotetext{
${ }^{68}$ para. 17, n. 59 above.

${ }^{69}$ Under Article 255(1) EC, any citizen of the Union, and any natural or legal person residing or having its registered office in a Member State, shall have a right of access to European Parliament, Council and Commission documents. Article 1(2) TEU provides that "[t]his Treaty marks a new stage in the process of creating an ever closer union among the peoples of Europe, in which decisions are taken as openly as possible and as closely as possible to the citizen". For analysis of these provisions, see the introduction to Chapter 4 and 4.1 .

${ }^{70}$ para. 28, n. 59 above. Article $253 \mathrm{EC}$ provides that "[r]egulations, directives and decisions adopted jointly by the European Parliament and the Council, and such acts adopted by the Council or the Commission, shall state the reasons on which they are based and shall refer to any proposals or opinions which were required to be obtained pursuant to this Treaty".

${ }^{71}$ para. 34, n. 59 above. See also Case 26/62, Van Gend en Loos v. Nederlandse Administratie der Belastingen [1963] ECR 1.

${ }_{72}$ para. 35 , n. 59 above.
} 
not directly applicable. ${ }^{73}$

As regards the second plea relating to a possible breach of Decision $94 / 90$, the CFI individually addressed the disputes concerning the documents originating from the Italian authorities and those drawn up by the Commission. As to the former, it held that " $[\mathrm{t}]$ he restrictions on access to documents originating with third parties and held by the institutions have no bearing on the duty imposed on those institutions under Article 253 EC to provide adequate reasoning for their decisions". ${ }^{74}$ Consequently, it held that "the Commission did not err in law in taking the view that it was not under an obligation to grant access to those documents". ${ }^{75}$ As regards the documents drawn up by the Commission, i.e. letters of formal notice and reasoned opinions drawn up within the context of proceedings instituted against Italy under Article $226 \mathrm{EC}$, the Court referred to the 1997 WWF judgment, stating that "the Member States are entitled to expect the Commission to guarantee confidentiality during investigations which might lead to an infringement procedure". ${ }^{76}$ It went on to say that:

This requirement of confidentiality remains even after the matter has been brought before the Court of Justice, on the ground that it cannot be ruled out that the discussions between the Commission and the Member State in question regarding the latter's voluntary compliance with the Treaty requirements may continue during the court proceedings and up to the delivery of the judgment of the Court of Justice. ${ }^{77}$

\footnotetext{
73 paras. 34 and 38 , n. 59 above.

74 para. 49 , n. 59 above.

75 para. 50, n. 59 above.

76 paras. 51 and 68, n. 59 above. The CFI referred to para. 63 of the WWF judgment, in which the Court said it considered that "the confidentiality which the Member States are entitled to expect of the Commission in such circumstances warrants, under the heading of protection of the public interest, a refusal of access to documents relating to investigations which may lead to an infringement procedure". Case T-105/95, WWF (United Kingdom) v. Commission [1997] ECR II-313. 77 para. 68, n. 59 above.
} 
The Court added that:

The preservation of that objective, namely an amicable resolution of the dispute between the Commission and the Member State concerned before the Court of Justice has delivered judgment, justifies refusal of access to the letters of formal notice and reasoned opinions drawn up in connection with the Article $226 \mathrm{EC}$ proceedings on the ground of protection of the public interest relating to inspections, investigations and court proceedings, which comes within the first category of exceptions in Decision 94/90. ${ }^{78}$

As regards the third plea concerning possible infringement of Article $253 \mathrm{EC}$, the applicants believed that the Commission's justification for its refusal lacked legal basis, reflecting that "infringement proceedings are conducted under conditions of absolute secrecy" ${ }^{79}$ They added that "according to settled case-law, the reasons given for refusing access must be sufficient and must involve a balance between the conflicting interests" ${ }^{80}$ However, the Court held, first, that the Commission had given sufficiently clear reasons for the contested decision. ${ }^{81}$ It stated that the Commission had referred to the authorship rule and stated that, under this rule, "the applicants' request had no basis because the documents sought had been written by a third party". It went on to say that "[s]uch a statement of reasons is sufficiently clear to enable interested parties to understand why the Commission did not forward to them the documents in question and to enable the Court to exercise its power to review the legality of the contested decision". ${ }^{82}$ Secondly, the Court stated that "the Commission indicated in the contested decision the reasons why it formed the view

${ }_{78}^{78}$ para. 68, n. 59 above.

79 para. 73, n. 59 above.

${ }^{80}$ para. 73, n. 59 above.

81 para. 77, n. 59 above.

82 para. 77, n. 59 above. 
that disclosure of the letters of formal notice and the reasoned opinions would have an adverse effect on the public interest". ${ }^{83}$ It therefore held that "the unavoidable conclusion is that the Commission did carry out such an examination". ${ }^{84}$

\subsubsection{Comment}

The information sought in this case concerned documents about infringement proceedings against Italy. Part of the documents was produced by the Italian authorities, while the other part was drawn up by the Commission. In its refusal, the Commission invoked the authorship rule and the public interest exceptions relating to investigations, inspections, and court proceedings. We will focus on the Court's opinions on the employment of these provisions. As Article 253 EC related to both the authorship rule and the three other exceptions, we will not follow the order of the applicants' pleas but take this provision into account when examining both topics.

\subsubsection{The authorship rule}

With regard to the authorship rule, we should consider whether Article 253 EC requires the Commission to justify its invocation of the authorship rule. The Court handed down a negative answer to this question, holding that " $[\mathrm{t}]$ he restrictions on access to documents originating with third parties and held by the institutions have no bearing on the duty imposed on those institutions under Article $253 \mathrm{EC}$ to provide adequate reasoning for their decisions". This stance is not surprising at all because,

${ }^{83}$ para. 80 , n. 59 above.

84 para. 80 , n. 59 above. 
under the authorship rule, it is the third parties rather than the Commission or the Council that decide whether the information provided by third parties should be released. Generally, as such an application must be sent to the author rather than the two institutions, it is the author that decided whether the request should be approved. Since the institutions do not make such decisions, it is inappropriate to demand that they justify their refusals. This was presumably the reason why the Court held that the reference of the authorship rule and the statement indicating that "the documents sought had been written by a third party" was sufficiently clear.

This judgment, however, demonstrated that the authorship rule was inconsistent with the principle of widest possible access. This principle, as we saw in 3.1.2, suggested that information should be provided to the citizen unless decision-makers within the EU have a good reason not to do so. What is the good reason, if any, behind the authorship rule? Obviously, the main purpose of this provision is to help maintain mutual confidence between the Commission and third parties. The relations between Brussels and Rome could have been strained, if the Commission had been entitled to make the decision and indeed approved the request for access to the documents originating from Italy. Any jeopardy to these ties should definitely be regarded as damage to public interest. Nonetheless, in addition to the authorship rule, the public interest exception relating to international relations was set out in the Code of Conduct. What was protected through the invocation of the authorship rule was not only the public interest above, but also the third parties' own interest in a denial of public access. The two institutions have no say on any disclosure of third party information on the one hand, and on the other, third parties tend to deny all access as long as third parties' interests are involved. It is fair to say that the authorship rule, which runs counter to the principle of widest possible access, constituted a major 
threat to FOI protection in the Union.

In addition, it was unclear whether release of the documents originating from Italy would be detrimental to diplomatic ties. Was the refusal actually beneficial to bilateral relations? The Court, as we saw earlier, avoided answering this question on the ground that it was unnecessary for the Commission to consider the principle of proportionality. Nonetheless, it should be noted that in reality such a rejection might neither benefit nor jeopardise bilateral relations. For instance, the first document requested by the applicants was a telex from an Italian government agency to Italian universities concerning the suspension of all relations or activities with lecturers following the judgment in Allue and Others. ${ }^{85}$ This document could be considered the evidence showing that the Italian authorities concerned had endeavoured to comply with the court decision. It was, as a result, unlikely that the granting of access to this document would put bilateral ties at any material risk.

\subsubsection{Public interest exceptions}

Invoking the public interest exceptions relating to investigations, inspections, and court proceedings, the Commission denied access to the letters of formal notice and reasoned opinions. What do these exceptions refer to? Is it appropriate to say that all the Commission-originated information relating to these three procedures should not be made available to the public? The answer is obviously negative, as it is impossible that all the documents about the procedures have public interest implications. But how narrow, or how broad, is this scope? If these exceptions are read in a strict manner, the information, disclosure of which would jeopardise those procedures' purposes, should not be made publicly available. Otherwise it should be accessible.

${ }^{85}$ n. 63 above. 
In this case however, as regards the notice and opinions, what the Court mainly considered was, inter alia, whether the Commission and Italy could reach an amicable resolution. The Court said that the refusal was justified because the Member State's voluntary compliance with the Treaty requirements might exist during the investigations, the inspections, and the court proceedings, adding that an amicable resolution of the dispute could be made before the Court delivered a judgment. ${ }^{86}$

It is of interest to refer to the 1998 van der Wal judgment when examining the present case. In van der Wal, the CFI said that the exception concerning court proceedings enshrined in Commission Decision 94/90 was designed to ensure respect for the right to a fair hearing. ${ }^{87}$ As the present case concerned not only the court proceedings but also the investigation and inspection exceptions, one might have expected the Court to take the view that the objective of the three exceptions was to guarantee fairness in relation to the three kinds of legal procedure. However, the Court, which did not even mention this essential purpose in the present case, turned to focus on another purpose, namely the pursuit of amicable resolutions of disputes.

This new interpretation of the public interest exceptions was flawed on the following grounds. First, it was extremely contentious to state that the three public interest exceptions were introduced to ensure Member States cooperation with the Commission and to create a harmonious atmosphere during legal procedures. It bears noting that the Member States are under the obligation to cooperate sincerely under Article 5 EC. Regarding the procedures, it is extremely rare to see genuine

\footnotetext{
${ }^{86}$ This opinion was in line with that of the Commission. In its refusal, the institution stressed that it was "genuine cooperation and an atmosphere of mutual trust between the Commission and the Member State concerned" that could enable the two parties to resolve the dispute rapidly.

${ }^{87}$ n. 61 above.
} 
cooperation and an amicable atmosphere when a Member State is suspected of infringing Community law. As little willing cooperation can be expected in these circumstances, we doubt whether pursuit of an amicable resolution, as opposed to fairness, is a main objective of the three exceptions. Second, even if an amicable resolution is reached prior to the judgment, it does not necessarily mean that the confidential content helps bring about the result. Many other factors might be taken into serious consideration before two parties could decide to end the procedures. In addition, as regards Article $253 \mathrm{EC}$ and the principle of proportionality, the views of the Court were controversial. This is because the Court did not consider whether the Commission had elaborated on how the refusal could bring about an amicable end to the dispute. Without even mentioning the principle of proportionality, the Court stated that "the Commission indicated in the contested decision the reasons why it formed the view that disclosure of the letters of formal notice and the reasoned opinions would have an adverse effect on the public interest". The Court failed to examine what was the adverse effect, if any, and whether the refusal could avoid the result.

In the present case, the Court cited a controversial statement it made in the $W W F$ judgment, in which it said that "the confidentiality which the Member States are entitled to expect of the Commission in such circumstances warrants, under the heading of protection of the public interest, a refusal of access to documents relating to investigations which may lead to an infringement procedure". ${ }^{88}$ Generally, when the Court determines whether the public interest exceptions are correctly invoked in a refusal, the major factor that should be considered is not expectation of the Member State concerned, because such anticipation mainly relates to the interest of the state

${ }^{88}$ n. 76 above. 
rather than that of the public. The fragile link between this expectation and the public interest seems to be: if the anticipation is not met, the state concerned could decline to cooperate genuinely with the Commission or the Court in future procedures, which could eventually do harm to the public interest. As we have seen earlier, however, there is little chance of a pleasant atmosphere when a Member State is alleged to have infringed Community law. The major issue that the Court must consider is whether a refusal could ensure fair legal procedures, because it is this objective that has straightforward impact on the public interest. In $W W F$ however, the Court did not focus on whether the investigation's purpose was endangered. In fact, that purpose was unlikely to be jeopardised as the investigation had been completed.

\subsubsection{Conclusion}

This judgment indicates that there was a potential conflict between the authorship rule and the spirit of the principle of widest possible access. Future controversy that could arise in this context might be the reason why the authorship rule is not included in the 2001 Regulation. Second, the Court agreed with the Commission that the pursuit of an amicable resolution was a compelling objective, but our analysis demonstrated that it was extremely difficult, if not impossible, to achieve this aim, and firm causal link between the refusal at issue and this aim does not always exist. Factors other than the refusal could attain the purpose. For instance, Italy might decide to comply with the Treaty requirements at issue during the court proceedings to preserve the national reputation. Thus, the exceptions relating to investigations, inspections, and court proceedings should be interpreted in a much stricter fashion.

This controversy remains after the 2001 Regulation came into force. Article 4(2) of this legislation provides that: 
The institutions shall refuse access to a document where disclosure would undermine the protection of:

- commercial interests of a natural or legal person, including intellectual property,

- court proceedings and legal advice,

- the purpose of inspections, investigations and audits, unless there is an overriding public interest in disclosure.

This provision does not touch on what constitutes the purpose of the exceptions relating to court proceedings, inspections, and investigations. The Court must in future examine whether the EU institutions have considered the principle of proportionality before refusing the public access. It should be stressed that limitless invocation of recklessly-interpreted exceptions will definitely endanger FOI protection in the Union.

\subsection{The Kuijer case ${ }^{89}$}

The CFI delivered the Kuijer judgment in February 2002, two months after it handed down Petrie. A major difference between these cases is that the Court did not mention the principle of proportionality in the former but stressed its importance in the latter.

\subsubsection{Facts and ruling}

Aldo Kuijer, a Dutch scholar in the field of asylum and immigration studies, was

${ }^{89}$ Case T-211/00, Aldo Kuijer v. Council [2002] ECR II-485. 
interested in certain Council documents concerning the activities of the Centre for Information, Discussion and Exchange on Asylum (CIREA).$^{90}$ In the present action, he sought annulment of a Council decision, which rejected his application for access to a number of CIREA documents. The request related to, first, certain reports drawn up by, or with, the CIREA and reports of joint missions, or reports on missions, carried out by Member States in third countries and sent to the CIREA. The Commission provided the applicant with various documents, but this did not alter the basic substance of dispute. Second, the applicant requested the list drawn up by, or with, the CIREA, of the contact persons in the Member States involved with asylum cases (the list of contact persons) and any subsequent changes to that list. ${ }^{91}$ The Court stressed that it must consider whether the contested decision was adopted according to, inter alia, the following principles:

Article 4(1) of Decision 93/731 must be interpreted in the light of the principle of the right to information and the principle of proportionality. Consequently, the Council must consider whether it is appropriate to grant partial access, confined to material which is not covered by the exceptions. In exceptional cases, a derogation from the obligation to grant partial access might be permissible where the administrative burden of blanking out the parts that may not be disclosed proves to be particularly heavy, thereby exceeding the limits of what may reasonably be required. ${ }^{92}$

The Council refused access to the requested reports by relying on the public interest exception relating to international relations set out in Article 4(1) of Decision 93/731. The application was refused on the ground that, "since their contents could be construed as criticism of the third countries in question, in particular as regards their

${ }^{90}$ para. 9, n. 89 above.

91 para. 9, n. 89 above.

92 paras. 57 and 58, n. 89 above. 
political situation and the situation concerning human rights, their disclosure could be prejudicial to the European Union's relations with those countries". ${ }^{93}$ The CFI disagreed with this approach and held that, first of all, "the mere fact that certain documents contain information or negative statements about the political situation, or the protection of human rights, in a third country does not necessarily mean that access to them may be denied on the basis that there is a risk that the public interest may be undermined" ${ }^{94}$ Secondly, the CFI stated that "[a]s regards their contents, the reports at issue do not concern directly or primarily the relations of the European Union with the countries concerned". ${ }^{95}$ Thirdly, "neither the nature nor the content of the reports is consonant with the reasons put forward by the Council in the contested decision to substantiate its refusal of the application for access". ${ }^{96}$ In addition, the CFI, which had in the Court proceedings ordered production of the reports concerned, stated that "disclosure of a large part of their contents clearly cannot be regarded as likely to give rise to tension with the third countries concerned". ${ }^{97}$ It ruled that "the Council therefore committed a manifest error of assessment in maintaining that the reasons on which it relied in order to refise access to the reports at issue apply to the documents in their entirety". ${ }^{98}$ The Court acknowledged that "public interest grounds may justify preserving the confidentiality of certain passages of several of the reports at issue". ${ }^{99}$ It however emphasised that in such cases, according to settled case-law, the Council "must grant partial access to

93 para. 59, n. 89 above.

${ }_{95}$ para. 60, n. 89 above.

95 para. 62, n. 89 above.

${ }_{96}$ para. 64, n. 89 above.

97 para. 69, n. 89 above.

98 para. 70 , n. 89 above.

99 para. 71, n. 89 above. For instance, according to the Court, "the people who have provided the information are cited, a refusal to disclose those passages being, to that extent, legitimate". 
the documents in question". 100

As regards the list of contact persons, the Court stated that the Council had refused to consider the possibility of granting access to the information, in particular the names of those persons. ${ }^{101}$ According to the judgment, the Council failed to establish "to what extent such a consideration might fall within the ambit of the exceptions provided for in Article 4 of Decision 93/731". ${ }^{102}$ The Court held that the Council, in refusing the applicant access to the information on the list of contact persons, had acted "in breach of the principle of proportionality". ${ }^{103}$ It therefore annulled the contested decision. ${ }^{104}$

\subsubsection{Comment}

As regards the principle of proportionality, the aim of the refusal was clear, which was to maintain, or at least not to worsen, the EU's relations with the countries whose situations had been analysed in the reports in question. However, the link between this objective and the means, i.e. the refusal, was very tenuous. The reports were not closely related to international relations. Refusal of the request for most of the documents was, therefore, irrelevant to attainment of the purpose. The Council rejected the request in its entirety, but access to only a part of the documents should not have been refused on the basis of the public interest in international relations. The Court disagreed with the Council mainly on the ground that there was no proper

100 para. 71, n. 89 above. The Court referred to paras. 73 and 74 of the Hautala judgment, n. 34 above.

101 para. 73, n. 89 above.

102 para. 73, n. 89 above.

103 para. 74, n. 89 above.

104 para. 75, n. 89 above. 
link between the aim and the means. As to the list of contact persons, the Council was held to have made another mistake. The Council did not plan to attain any purpose in the refusal concerned, and consequently failed to consider whether there was a sufficient link between the aim and the means. The Council, in fact, did not even consider the possibility of granting access to the information.

The Court carefully considered whether the Council had followed the principle of proportionality before adopting the contested decision. Nevertheless, from a comparative perspective, we can see that the Court has not done so consistently in the FOI field. The ECJ and the CFI made intensive proportionality reviews in the Hautala and Kuijer cases, ${ }^{105}$ while the CFI failed to do so in the Petrie judgment. As the public interest exception relating to international relations was invoked in the contested decisions in both Hautala and Kuijer, it is doubtful whether the Council and Commission have to consider the principle of proportionality only in the circumstances where the international relations exception is invoked. As regards Hautala and Kuijer, the Courts did not give a clear answer. In addition, other exceptions might also be invoked to secure the public interest relating to international relations in an indirect fashion. For instance, the authorship rule may be invoked by the Council or Commission in a refusal to protect international relations. Since the international relations exception is not the only exception that concerns the protection of the public interest relating to international relations, the Court's proportionality review should not be limited to invocations of this particular exception.

It is worth noting that the principle of proportionality has not been included in the 2001 Regulation. Under Article 4(2) of this Regulation, documents held by the 105 n. 34 above. 
Council, the Commission, and the Parliament should not be released unless there is an overriding public interest in the disclosure. Is this a provision that requires the institutions to take serious account of the principle of proportionality before adopting a refusal? This provision indicates that the institutions should apply a balancing test before approving or denying public access. This test, as we saw earlier, to some extent operates in a similar way to the principle of proportionality, but analysis of the Hautala and Kuijer judgments above has indicated that the Courts never regarded the provision as imposing a proportionality requirement. ${ }^{106}$

\subsection{The Interporc II case c $^{107}$}

This action concerned implementation of the 1999 Interporc I judgment examined in 3.5.1, but what was under appeal was not that decision but another dispute brought to the CFI after Interporc $I .{ }^{108}$ Like the 2001 Petrie case, this judgment concerned the public interest exception relating to court proceedings, as well as the authorship rule.

\footnotetext{
${ }^{106}$ Certain key issues, in particular those concerning the principle of proportionality and the authorship rule, might have arisen in the BAT (Investment) case. In this case, British American Tobacco (Investments) Ltd sought to annul a Commission decision that denied access to certain documents concerning preparatory work relating to the Commission proposal for a directive on the approximation of the Member States laws concerning the manufacture, presentation and sale of tobacco products. The nature of the case was, however, fundamentally altered when the Commission provided the applicant with various relevant documents during the court proceedings. The CFI dismissed the applicant's action mainly on the ground that copies of all the relevant Commission documents had been offered to the applicant. The CFI, therefore, did not address the essential issues which had arisen in the original dispute. Case T-311/00, British American Tobacco (Investments) Ltd $v$. Commission [2002] ECR II-2781.

${ }^{107}$ n. 58 above.

108 The Interporc I case citied by the ECJ in the present judgment referred to Case T-124/96, Interporc Im- und Export GmbH v. Commission [1998] ECR II-231. The judgment which was appealed was another case brought to the CFI, namely Case T-92/98, Interporc v. Commission [1999] ECR II-3521.
} 
These issues became extremely contentious after the 2001 Regulation came into force.

\subsubsection{Facts and ruling}

What the German company requested in Interporc I was information concerning the control procedures for imports of Hilton beef and inquiries which gave rise to Germany's decision to effect the recovery of import duty. ${ }^{109}$ The information at issue included two categories of document: the documents drawn up by the Commission and those drawn up by the Member States or the Argentine authorities. Although the CFI annulled the contested Commission decision in Interporc I, the Commission did not implement that judgment in the way expected by the applicant. The Commission sent to the firm another decision dated 23 April 1998, containing a conclusion identical to that in the annulled decision in Interporc I, but the Commission employed different reasons, basing its new refusal on the authorship rule and the public interest exception relating to court proceedings. ${ }^{110}$ The applicant then brought an action before the CFI to annul this new Commission decision.

As regards the documents emanating from the Commission, the CFI stressed that 'the expression 'court proceedings' must be interpreted as meaning that the protection of the public interest precludes the disclosure of the content of documents drawn up by the Commission solely for the purposes of specific court

\footnotetext{
${ }^{109}$ para. 13 of the Interporc I judgment, n. 108 above.

110 para. 20 of the CFI judgment, n. 108 above. The Commission said all the documents it drew up concerned pending legal proceedings, which referred to Case T-50/96, Primex Produkte Import-Export $G m b H \&$ Co. KG, Gebr. Kruse GmbH, Interporc Im- und Export GmbH v. Commission [1998] ECR II-3773.
} 
proceedings". ${ }^{111}$ The CFI stated that this exception's purpose "is to ensure both the protection of work done within the Commission and confidentiality and the safeguarding of professional privilege for lawyers". ${ }^{112}$ This exception "cannot enable the Commission to escape from its obligation to disclose documents which were drawn up in connection with a purely administrative matter" (emphasis added). ${ }^{113}$ The Commission's interpretation nonetheless "applies generally to requests for access to documents emanating from the public", which "runs counter to one of the essential objectives of Decision 94/90, namely to give citizens the opportunity to monitor more effectively the lawfulness of the exercise of public powers", according to the judgment. ${ }^{114}$ The CFI held that "the Commission has misapplied the exception based on the protection of the public interest (court proceedings)", annulling the part of the contested decision which denied access to the information originating from the Commission. ${ }^{115}$ These findings are convincing because it can be noted that they are very different from those expressed by the CFI in the Petrie judgment.

What led the applicant to appeal this CFI judgment to the ECJ was, however, not the findings above but those concerning the documents drawn up by the Member States or the Argentine authorities. In this regard, the CFI dismissed all the applicant's pleas on the ground that, first of all, the authorship rule was applicable as there was "no rule of law of a higher order according to which the Commission was not empowered, in Decision 94/90, to exclude from the scope of the Code of

111 para. 40, n. 108 above.

112 para. 41, n. 108 above.

113 para. 42, n. 108 above.

114 paras. 43 and 44, n. 108 above.

115 paras. 48 and 49, n. 108 above. 
Conduct documents of which it was not the author". ${ }^{116}$ Secondly, the CFI held that the authorship rule was neither misinterpreted nor misapplied. It said, as authors of the five types of documents concerned were either the Member States or the Argentine authorities, the Commission had applied the authorship rule correctly in taking the view that it was not required to grant access to those documents. ${ }^{117}$ Thirdly, as to the Article 190 (now Article 253) obligation to state reasons, the CFI stated that "in the contested decision the Commission referred to the authorship rule and informed the applicant that it should request a copy of the documents in question from the Member States concerned or the Argentine authorities. Such a statement shows clearly the reasoning of the Commission". ${ }^{118}$ The ECJ agreed with the CFI on all the points above and dismissed the applicant's claims. ${ }^{119}$

\subsubsection{Comment}

Here we focus on the changes to the CFI's opinions relating to the court proceedings exception, the incompatibility of the authorship rule with the framework established by the Code of Conduct and the corresponding Commission and Council decisions.

\subsubsection{The court proceedings exception}

As regards the public interest exception relating to court proceedings, the CFI annulled part of the contested Commission decision on the basis that:

116 para. 66 , which was referred to in para. 41 of the ECJ judgment, n. 58 and 108 above.

117 paras. 73 and 74, which were cited by the ECJ in paras. 50 and 51 of its judgment, n. 58 and 108 above.

${ }_{118}$ para. 78 . The ECJ in its judgment referred to this paragraph but mistakenly put paragraph 78 as paragraph $74, \mathrm{n} .58$ and 108 above.

119 n. 58 above. 
(1) The protection of court proceedings could relate solely to the purposes of specific court proceedings.

(2) Documents drawn up in connection with a purely administrative matter do not fall within its scope.

(3) The Commission nevertheless applied this exception generally to requests for access to documents emanating from the public, including those concerning the purposes of specific court proceedings and purely administrative matters.

The first point marked an alteration to the CFI's views on the court proceedings exception. In the Petrie judgment, the CFI emphasised that the pursuit of an "amicable resolution" was the purpose of that exception relating to investigations, inspections, and court proceedings. The scope of this exception drawn in Petrie was indistinct and much wider than that drawn in the present case. Obviously, the scope drawn in Petrie had little to do with the purposes of specific court proceedings because these procedures are not intended for adopting amicable resolutions. They are designed mainly to ensure the enforcement of Community law.

\subsubsection{The authorship rule}

Both Courts held that the Commission' partial refusal based on the authorship rule did not constitute a breach of Decision 94/90, the Code of Conduct, or former Article $190 \mathrm{EC}$. They came to this conclusion on the following grounds:

(1) The authorship rule was applicable.

(2) The Commission application of this rule was correct.

(3) The refusal concerned provided the applicant and the Court with clear reasoning. 
The Courts were right in delivering these opinions, but what they failed to consider was the incompatibility of this rule with the framework of the Code of Conduct and the two corresponding Commission and Council decisions.

The Courts avoided considering what the objective of the authorship rule was. The point was that there should not be any limitless exceptions in the EU freedom of information law. First of all, the authorship rule ran against the principle of widest possible access set out in the Code of Conduct. This judgment suggested that, as long as a Commission or Council document originating from third parties related to their own interest, internal or external, significant or minor, the principle of widest possible access did not apply. Undoubtedly, this did not necessarily mean that absolute secrecy prevailed over public access as far as this kind of information was concerned, because it could still be available to the public under the FOI laws in the Member States concerned. However, this wide-ranging exception to openness has posed a major threat to the principle of widest possible access.

Secondly, this exception runs counter to the very objective of Decision 94/90, which was, in the CFI's words, "to give citizens the opportunity to monitor more effectively the lawfulness of the exercise of public powers". ${ }^{120}$ A document drawn up by a third party is sent to the EU because it concerns the operation of the Union. However, this document is never publicly available under the EU FOI regime since it falls within the ambit of the authorship rule. Under this rule, secrecy is the rule, which deprives the public of the chance to scrutinise the exercise of public powers at the Union level.

Thirdly, the purpose of the authorship rule is particularly vague. The Courts

${ }^{120}$ para. 43 of the CFI judgment, n. 108 above. The CFI stressed the significance of this objective when addressing the disputes concenning the documents emanating from the Commission, but it was tightlipped on the compatibility of the authorship rule with this purpose. 
made considerable efforts to address the lawfulness and application of this rule, but they failed even to mention its objective. As we have seen in 5.3.3, the purpose could be to secure mutual trust between the two institutions and the third parties, but a refusal might have little to do with the bilateral confidence. The information concerned in the present case included the documents concerning the control procedures for imports of Hilton beef and to the inquiries which gave rise to Germany's decision to effect the recovery of import duty. It was very unlikely, if not impossible, that disclosure of such information would have either significantly enhanced or jeopardised mutual trust among the parties.

In brief, the Courts read the authorship rule technically so that it operated in a very restrictive manner, ${ }^{121}$ and they did not touch upon its incompatibility with the framework based on the Code of Conduct. It is thus interesting to note that this highly controversial provision has been removed from the EU FOI framework, and has been replaced by Article 4(5) of the 2001 Regulation. ${ }^{122}$

\subsection{The Mattila case}

Mandatory exceptions were set out in Article 4(1) of Council Decision 93/731. The

\footnotetext{
${ }^{121}$ The CFI repeated that position in a 2003 judgment. Case T-47/01, Co-Frutta Soc.coop.rl v. Commission [2003] ECR II-4441. An Italian cooperative society of banana ripeners, applied for annulment of the Commission's decision, by which access to the documents sought by the applicant in connection with the arrangements for importing bananas was partly refused. Stressing that the authorship rule was "an absolute and unqualified exception for documents authored by a third party", the CFI stated that "since the Code of Conduct does not provide for any restriction on the application of that rule, it must be construed as meaning that it is fully applicable to every sort of third party document to which access is sought, and it is not possible to have different levels of applicability", paras. 59 and 60. In this judgment, the Court reaffirmed its stance on invocation of the authorship rule in a clearer fashion.

${ }^{122}$ This new provision will be examined in detail at 5.7.2.1 below.
} 
CFI stated in Hautala that this provision "must be interpreted in the light of the principle of the right to information and the principle of proportionality. It follows that the Council is obliged to examine whether partial access should be granted to the information not covered by the exceptions". ${ }^{123}$ The ECJ later endorsed this approach, which put the Council and Commission under an explicit obligation. But will this always be the case? Does failure to meet this requirement necessarily infringe the principle of proportionality? In what particular circumstances, if any, could there be an exemption from this duty? This is the principal issue in Mattila $v$. Council and Commission, on which the $\mathrm{CFI}^{124}$ and $\mathrm{ECJ}^{125}$ held divergent opinions.

\subsubsection{Facts and ruling}

Olli Mattila, a Finn, sought from the CFI annulment of the Commission's and the Council's decisions of 5 and 12 July 1999 refusing him access to certain documents drawn up by the Council, the Commission, or jointly. ${ }^{126}$ Most of the requested documents held by the Council related to negotiations with certain third countries. ${ }^{127}$ The requested information in possession of the Commission concerned the future position of the Union regarding its relations with Russia. ${ }^{128}$ Both institutions refused the initial and confirmatory requests on the basis of the protection of the public interest relating to international relations set out in the Code of Conduct and in

\footnotetext{
para. 87 , n. 34 above. Emphasis added.

24 Case T-204/99, Olli Mattila v. Council and Commission [2001] ECR II-2265.

${ }^{125}$ Case C-353/01, Olli Mattila v. Council and Commission [2004] ECR I-0000.

126 paras. $9,10,11$, and 17 , n. 124 above.

127 para. 12, n. 124 above.

128 para. 15, n. 124 above.
} 
Article 4(1) of Decision 93/731. ${ }^{129}$ The applicant said the contested decisions constituted a "breach of the principle of proportionality in that partial access to the documents in question has not been granted or even considered" ${ }^{130}$ The institutions in response did not dispute that "they had failed to consider the possibility of granting partial access to the documents in question". ${ }^{131}$ The CFI nonetheless held that "having taken account of the explanations they have proffered and in view of the nature of the documents in question, it seems that, had they done so, they would not in any event have agreed to partial access", according to paragraph 71 of this judgment. ${ }^{132}$ It stated that "[g]iven the particular circumstances of the present case, the fact that the defendant institutions failed to consider the question of granting partial access had no effect on the outcome of their examination". ${ }^{133}$ It therefore held that the institutions "did not infringe the principle of proportionality by failing to grant partial access to the documents at issue". ${ }^{134}$ It dismissed this action after rejecting other pleas as well.

Advocate General Léger harshly criticised the CFI judgment, stating that it had jeopardised the right of Mr. Mattila to a fair hearing. ${ }^{135}$ Mr. Léger stated that this judgment had deprived the appellant "of the possibility of mounting an effective challenge to the grounds on which the defendant institutions consider in the present case that partial access to the documents at issue is not possible". ${ }^{136} \mathrm{He}$ added that Mr. Mattila was "unable to discuss them during the administrative procedure, nor could he learn of them in time to assert his rights before the Court of First

${ }_{129}$ paras. $12,13,15$, and 16, n. 124 above.

130 para. 28, n. 124 above.

131 para. 71, n. 124 above.

132 n. 124 above.

133 para. $71, \mathrm{n} .124$ above.

134 para. 74 , n. 124 above.

135 Opinion, point 59.

136 Opinion, point 62 . 
Instance". ${ }^{137}$

The ECJ also disagreed with the CFI. By reference to the views of Mr. Léger, the ECJ held that "[the CFI] wrongly held, in paragraph 71 of the contested judgment, that such an error of law does not result in the annulment of the contested decisions". ${ }^{138}$ It stated that "[o]n that ground alone, Mr Mattila's submission that the contested judgment is vitiated by an error of law is well founded". ${ }^{139}$ Setting aside the contested judgment, it held that the contested decisions must be annulled since the institutions failed to consider the possibility of partial access to the documents concerned. $^{140}$

\subsubsection{Comment}

We will consider whether the Council and Commission should have applied the principle of proportionality in dealing with this dispute, which concerned the public interest exception relating to international relations. Is this obligation a requirement? If the answer is positive, we should explore the reasons behind it, i.e. the purposes that could be attained through carrying out this duty. If the answer is negative, we must then consider what specific situations, if any, should be exempted from this requirement. To answer this question, the relations between the denial concerned and the purposes of the principle of proportionality must be examined in depth.

137 Opinion, point 62

138 paras. 31 and 32 , n. 125 above.

139 para. 33, n. 125 above.

140 paras. $34,36,37$, and 38 , n. 125 above. 


\subsubsection{The first purpose}

The case law indicates that the principle of proportionality has been applied in the EU FOI field to achieve two principal aims. ${ }^{141}$ The first is to ascertain whether there is a reasonable relation between the means, namely the refusals, and the ends, namely, the public or private interests that could be protected through the refusals. In the present case, it was not disputed that the Council and Commission did not consider whether there was an appropriate relationship between the refusals of partial access and any public interest that could be secured through the denials. In short, the institutions failed to apply the principle of proportionality when making their determination. It should, however, be stressed that this does not mean that a reasonable relation did not exist. Just as the CFI stated in its judgment, had the institutions considered the possibility of granting partial access, "they would not in any event have agreed to partial access". The relation between the means and the aim might be perfectly plausible. The CFI, as a result, held that the institutions did not infringe the principle of proportionality by failing to grant partial access to the documents at issue. With regard to this first purpose, the CFI decision was not controversial. What the Court suggested was that the failure to consider this compelling principle of Community law did not necessarily mean that it had been infringed in practice.

\subsubsection{The second purpose}

The CFI nonetheless ignored another major purpose of the principle of proportionality, which is to help applicants access reasoning about the relation between the means and the ends. Mr. Léger rightly pointed out that the CFI judgment

${ }^{141}$ The Hautala case, n. 34 above, and Kuijer judgment, n. 89 above. 
deprived Mr. Mattila of the right to a fair hearing. Little account of this crucial purpose could be found in the CFI judgment. In fact, the two institutions presented their views on the application of the principle of proportionality, namely consideration of granting partial access, for the first time before the CFI. This rendered it extremely difficult for Mr. Mattila properly to exercise his right to a fair hearing. This was the main reason why the CFI judgment was set aside by the ECJ. In addition to this right, at present, applicants are also entitled to make a complaint to the EU Ombudsman. The grounds concerning how the principle of proportionality is applied would definitely help applicants decide whether they would "institute court proceedings against the institution and/or make a complaint to the Ombudsman, under the relevant provisions of the EC Treaty". Both rights are set out in Article 8(3) of the Regulation.

\subsubsection{Broader issues}

Our analysis has indicated that the exception invoked in the present case, i.e. the public interest exception relating to international relations, should be interpreted in the light of the principle of proportionality. What remained undecided was whether the Council and Commission bore such a duty when invoking the other exceptions set out in the Code of Conduct. It should be noted that there is a need to attain the two purposes of the principle of proportionality in the FOI field. The need of an applicant to, first, ascertain whether there is a reasonable relation between a refusal and the public or private interest intended to be protected through the refusal, and second, to access reasoning about such a relation, does not differ depending on the exception invoked by the institutions. However, under the Code of Conduct, the principle of proportionality did not apply to all the exceptions. This issue may be of 
historical interest only. Attention should be drawn to the fact that, under the 2001 Regulation, this principle does not apply to all the exceptions either. This means that this Regulation is insufficient to redress the difficulty noted above. Thus, the Regulation should be amended to have the principle of proportionality applied not only to an invocation of the public interest exception relating to international relations but also to that of the other exceptions.

\subsection{The Messina case ${ }^{142}$}

The authorship rule in the Code of Conduct led to a number of bitter disputes, in particular where the requested documents held by an institution were drawn up by the Member States. ${ }^{143}$ In fact, since early 2002, among all the judgments concerning documents originating from third parties, the Member States are the only group of third parties involved. The present case was the first concerning a request made under the 2001 Regulation. It indicated how the Court addressed disputes about information emanating from a Member State during the third stage of EU FOI evolution.

${ }^{142}$ Case T-76/02, Mara Messina v. Commission [2003] ECR II-3203.

${ }^{143}$ For instance, the 2001 Petrie judgment concerned certain documents drawn up by the Italian authorities, and the 2003 Interporc II judgment was about information originating from the Member States or the Argentine authorities, n. 58 and 59 above. The present case was mainly about documents drawn up by the Italian authorities. 


\subsubsection{Facts and ruling}

The applicant, Mara Messina, was a lecturer in law at two Italian universities. ${ }^{144}$ Messina, who was preparing a study on "the effects of State aid on undertakings in the less-favoured regions of the South of Italy", applied for annulment of a Commission decision refusing her access to certain documents originating from the Italian authorities and concerning the State aid scheme, which was the subject of an earlier Commission decision. ${ }^{145}$ The Commission delivered this refusal after asking the Italian authorities whether they agreed with the applicant being sent the documents. ${ }^{146}$ In response, "the Italian authorities, by letter of 16 May 2002, stated that they agreed with her being refused access". ${ }^{147}$ This dispute mainly concerned the "non-disclosure" rule, namely Article 4(5) of the 2001 Regulation, which states that "[a] Member State may request the institution not to disclose a document originating from that Member State without its prior agreement" (emphasis added). The applicant argued that Italy "did not expressly request the non-disclosure of the documents sought. That position does not preclude the possibility of a later decision by the Commission opposite to that forming the subject-matter of this action". ${ }^{148}$

The CFI stated that "the consultation of the Italian authorities was manifestly necessary, since the applicant's application for access covered documents sent to the institution prior to the date on which Regulation No 1049/2001 entered into force". ${ }^{149}$ Examining a number of facts, it demonstrated the reasons why it believed that the

144 para. 6, n. 142 above.

145 The Commission's Decision of 2 August 2000 (State Aid N 715/99 - Italy (SG 2000 D/10574)), http://www.europa.eu.int/comm/competition/state_aid/register/ii/by_case_nr_168.html. para. 7, n. 142 above.

146 para. 12 , n. 142 above.

147 para. 12 , n. 142 above.

148 para. 31, n. 142 above.

149 para. 42 , n. 142 above. 
Commission was "justified in taking the view that it had, prima facie, received an objection from the Italian Republic to the communication of the documents requested by the applicant, in accordance with Article 4(5) of Regulation No 1049/2001". ${ }^{150}$ The CFI stressed that there was "no ambiguity as to the negative nature of the Italian authorities' reply and, therefore, as to their objection, in accordance with Article 4(5) of Regulation No 1049/2001, to any disclosure of documents drawn up by them in the course of the examination of the aid scheme in question". ${ }^{151}$ It held that the denial of access to the information drawn up by the Italian authorities "appears to be legally justified" and dismissed this action. ${ }^{152}$

\subsubsection{Comment}

We will first compare the authorship rule and the non-disclosure rule better to understand the latter. ${ }^{153}$ The manner in which the Court read the non-disclosure rule when addressing this dispute will be focused on in the second part of our analysis.

\subsubsection{Two principal changes}

The authorship rule is not included in the 2001 Regulation, but attention should be drawn to Article $4(5)$ of this legislation, which concerns a special exception to

\footnotetext{
${ }^{150}$ paras. 35,43 , and 48 , n. 142 above.

151 para 52, n. 142 above.

152 paras. 56 and 57, n. 142 above.

153 This provision transposes Declaration 35 annexed to the final act of Amsterdam, by which the Conference agreed that the principles and conditions referred to in Article 191a(1) EC (now Article 255 EC) would "allow a Member State to request the Commission or the Council not to communicate to third parties a document originating from that State without its prior agreement" (emphasis added).
} 
openness. ${ }^{154}$ There are two major differences between these two provisions. The first change is that the authorship rule concerns the third parties including a natural or legal person, a Member State, another EC institution or body or any other national or international body, but under Article 4(5) of the Regulation, only the Member States are subject to special treatment. This is a significant difference, but it does not necessary mean that there will be fewer relevant disputes before the Court. This is because, as we have seen in this chapter, the institution-held information originating from the Member States has proven extremely controversial under the previous FOI legal framework. The information at issue in the present case also falls within this category of information.

The second change concerns the application process. Under the authorship rule, a request for access to the specific category of information, drawn up by the third parties and held by the Council and Commission, should be sent to the third parties concerned. Under the new provision, an application for access to the information drawn up by the Member States and held by the three institutions is made to the institutions, while the Member States are entitled to take the initiative in requesting the institutions not to disclose information originating from those states. A serious point here concerns the legal status of such a request. Is it a right merely to express an objection and the three institutions should make their own decisions? Or are the institutions bound by such a request?

Professor Patrick Birkinshaw gives a short answer to these questions, which is that "[t]he institutions should be mindful of, but not be bound by" such a request, but

\footnotetext{
${ }^{154}$ In this judgment, the Court held that "the power conferred on Member States to request the non-disclosure of their documents to third parties without their prior agreement is one of the exceptions to the right of access to documents of the institutions which are laid down in Article 1 of Regulation No 1049/2001”. para. 55, n. 142 above.
} 
he does not elaborate on this view. ${ }^{155}$ It should be stressed that all the Member States documents held by the institutions are closely related to not only the work of the Member States, but also that of the Union. Recital 10 of the 2001 Regulation states that "[i]n order to bring about greater openness in the work of the institutions, access to documents should be granted by the European Parliament, the Council and the Commission not only to documents drawn up by the institutions, but also to documents received by them". As both the institutions and the Member States are obliged to attain this purpose, the Member States' requests for non-disclosure should not be regarded as final decisions on possible releases. Otherwise, the institutions are excluded from performing their duty to bring about this purpose. It bears noting that another purpose of the legislation, according to Article 1(c) of the Regulation, is "to promote good administrative practice on access to documents". ${ }^{156}$ Although the scope of this objective is not perfectly clear, to avoid assessing the Member States' requests for non-disclosure apparently runs counter to this purpose.

What then should be considered is whether the Council, the Commission, and the Parliament must give adequate reasoning in their decisions, to meet the requirement set out in Article 253 EC. Similar disputes were repeatedly presented before the Court before the 2001 Regulation came into force. An explicit stance of the Court can be found in Petrie, in which the judges held that when the Council or Commission invoked the authorship rule in a denial, "[ $t]$ he restrictions on access to

${ }^{155}$ P. Birkinshaw, European Public Law (London, Butterworths, 2003), 278.

156 Article 15 of the Regulation entitled "Administrative practice in the institutions" provides that:

1. The institutions shall develop good administrative practices in order to facilitate the exercise of the right of access guaranteed by this Regulation.

2. The institutions shall establish an interinstitutional committee to examine best practice, address possible conflicts and discuss future developments on public access to documents.

It should, however, be stressed that the scope of promotion of good administrative practice on access to documents, set out in Article 1(3) of the Regulation, is not confined to the scope of Article 15. 
documents originating with third parties and held by the institutions have no bearing on the duty imposed on those institutions under Article $253 \mathrm{EC}$ to provide adequate reasoning for their decisions". ${ }^{157}$ This view was appropriate because such a request was not made to the two institutions under the authorship rule. ${ }^{158}$ Under Article 4(5) of the Regulation, however, an application for access to a document, which is drawn up by a Member State and held by an institution, is sent to the institution. ${ }^{159}$ As the request for non-disclosure is made to the institution, it is the institution that addresses such a request. Therefore it should not avoid meeting the requirement in Article 253 EC.

\subsubsection{Changes ignored}

In this judgment, the judges made a significant effort to examine the evidence before stating that there was "no ambiguity as to the negative nature of the Italian authorities' reply". They then jumped to the conclusion that the Commission denial "appears to be legally justified". Nevertheless, issues surrounding the nature of the reply from Italy and the legal status of the Commission refusal, as well as their relations were much more complicated than they were presented in this judgment.

The first issue concerned the entitlement of Italy to take the initiative. The Member State did not request the Commission not to release the document concerned. What the Italian authorities did was to respond to the Commission inquiry in a passive manner, though it agreed on the denial of access. The Court stated that the consultation was "manifestly necessary" since the application for access covered

\footnotetext{
${ }_{158}^{157}$ para. 49 of the Petrie judgment, n. 59 above.

158 Nonetheless, as we have seen in 5.3.3, the Court did not examine the incompatibility of the authorship rule with the principle of widest possible access.

${ }_{159}$ This rule does not prejudice the right to access the same document held by that Member State under its domestic FOI law.
} 
documents sent to the institution before the 2001 Regulation entered into force. This view is controversial because Article 4(5) of the Regulation does not require the Commission to make such an inquiry. Its only duty was to inform Italy of the request at issue. Even if Italy did not notice that it had sent the documents to the Commission before the Regulation came into force, a simple notice was sufficient for removing the lack of awareness. The Court, however, wrongly held that the consultation was manifestly necessary, which deprived Italy of the entitlement to take the initiative under the non-disclosure rule.

Secondly, as we have seen above, the institutions are not bound by the requests from the Member States, mainly because both the institutions and the Member States are under the obligation to realise openness of the EU institutions. In the present case, those documents concerned the state aid scheme which was the subject of a Commission decision. As to whether the information about the making of the Commission decision should be made available to the European public, it is improper to say that only the Italian authorities concerned were entitled to have the final say. However, the Court's view indicated that the Commission was bound by the negative nature of that reply, and the Commission refusal was therefore "legally justified".

Thirdly, as the Court was of the opinion that the Commission was bound by the negative reply from Italy, it is not surprising that the Court ignored the fact that the Commission did not take Article $253 \mathrm{EC}$ or the principle of proportionality into consideration before delivering its refusal. At present, as it is the duty of the Council, the Commission, and the Parliament to deal with such applications, they should face these requirements in a more serious manner. 


\subsubsection{Conclusion}

It can be concluded that the non-disclosure rule is very different from the authorship rule. First of all, the former merely concerns the Member States. Secondly, under this new rule, the three institutions are not bound by the Member States' requests for non-disclosure. Thirdly, under this new rule, the institutions must consider the obligation set out in Article $253 \mathrm{EC}$ to give sufficient reasons for their decisions. In this judgment, the Court noticed the first point but ignored the other two, which could trigger future disputes over invocation of the non-disclosure rule. To avoid this controversy, the EU legislator should consider amending the provision, requiring that the three institutions carefully consider of the principle of proportionality whenever the Member States express their objection to releases of information.

\subsection{Towards better protection}

In May 2001, the European Parliament and Council adopted Regulation EC 1049/2001, which marked the beginning of the third stage of the EU FOI evolution. Article 17(2) of this legislation provides that "[a]t the latest by 31 January 2004, the Commission shall publish a report on the implementation of the principles of this Regulation and shall make recommendations, including, if appropriate, proposals for the revision of this Regulation and an action programme of measures to be taken by the institutions" (emphasis added). This report published on 30 January 2004 is of great importance, in that the Commission reviewed the practice of the three major 
institutions on freedom of information. ${ }^{160}$ In this section, we compare the results of our analysis to the conclusions reached in the Commission report. This comparison aims to highlight how the Regulation could be revised in the future.

\subsubsection{No problems?}

The Commission says in the report that there is no need for any revision of this legislation. "Regulation 1049/2001 has been applied for two years and no problems have arisen during implementation that would justify amending legislation for the time being" (emphasis added), according to the report. ${ }^{161}$ The Commission goes on to say that "further experience is needed and significant case law must be developed before considering any amendment of texts regulating public access to documents. However, it would be advisable to consider ways of protecting institutions better against obviously unfair applications" (emphasis added). ${ }^{162}$ What it has claimed is that it is unnecessary to revise the Regulation since the more than two years of implementation experience was insufficient to assess its operation properly, ${ }^{163}$ and that the Courts have delivered only a few decisions on disputes about the Regulation. The Commission appears to believe that the only additional measures that should be adopted are those that could help reduce obviously unfair applications, though it is

\footnotetext{
${ }^{160}$ The Commission, n. 2 above.

${ }^{161}$ The Commission, n. 2 above, at 44. Also, in the conclusion of the 2003 Council FOI report, the Council boasts that "[t]he Council's experience in connection with the implementation of Regulation No 1049/2001 in 2003 has shown that application of the Regulation's provisions causes no particular problems either with regard to the analysis of documents for which access is requested or with regard to compliance with the response times laid down by the Regulation" (emphasis added). The Council, $\mathrm{n}$. 7 above, at 36 .

162 The Commission, n. 2 above, at 44 .

${ }^{163}$ The Regulation came into force in December 2001.
} 
not at all clear what this phrase refers to.

First of all, as to the claim relating to lack of experience, it is worth noting that the 2001 Regulation is not the first legal instrument in the EU FOI field. The Council and the Commission have much experience in the enforcement of Council Decision 93/731 and Commission Decision 94/90 over the last decade. Secondly, it is true that, before the Courts, there have been only a few decisions on disputes relating to rules of the Regulation, but the institutions should not ignore the significant body of case law regarding disputes about earlier Council and Commission decisions. It is very unlikely that the Courts would desert all their prior opinions on major FOI issues in the near future. ${ }^{164}$ This is mainly because the previous and current regimes have similar fundamental architecture and share the same philosophy, namely the spirit of "widest possible access". Thirdly, as regards the obviously unfair applications, Article 6(2) and Article 6(3) of the Regulation provide methods to address sufficiently imprecise requests, as well as applications for access to very long documents. If these provisions have proven to be insufficient to address abuses of the right to information in 2002 and 2003, there is then an imminent need for incorporating effective measures into this legislation to reduce such abuses. In addition, if Article 6(2) and Article 6(3) of the Regulation are insufficient to deal with unfair applications, it is then inappropriate for the Commission to have claimed that "no problems have arisen during implementation that would justify amending

\footnotetext{
${ }^{164}$ For instance, as to the interpretation of the phrase "court proceedings" in Article 4(2) of the Regulation, the CFI stated in the 2004 Turco judgment that "[g]iven that the term 'court proceedings' has been interpreted in the context of the right of public access to the institutions' documents, the Court considers that that definition, reached for the purpose of interpreting Decision $94 / 90$, is relevant for the purposes of Regulation No 1049/2001" (emphasis added). para. 65, Case T-84/03, Maurizio Turco v. Council [2004] ECR II-0000. In para. 72 of Verein für Konsumenteninformation v. Commission, the CFI also stressed that "[i]n view of the fact that the conditional form is maintained in Article 4(1) to (3) of Regulation No 1049/2001, the case law developed in connection with the code of conduct is capable of being applied to Regulation No 1049/2001". Case T-2/03, Verein für Konsumenteninformation v. Commission [2005] ECR II-0000.
} 
legislation for the time being".

The logic of the Commission reasoning demonstrated in the report is that no effort should be made unless the Member States ratified the Treaty establishing a Constitution for Europe. The Commission states that:

The [Constitutional Treaty could] extend the right of access to documents and to strengthen the dialogue between the institutions and civil society. The Regulation should be thoroughly revised in this respect. It should, at the very least, be adapted in order to be applicable to all the Union's institutions, bodies and agencies, given their very different roles. The Regulation would thus become a framework law, the implementing arrangements for which would have to be laid down in the rules of procedure of the organisations concerned. ${ }^{165}$

An extension of FOI protection is absolutely crucial. In the Constitutional Treaty, Article II-102 entitled "Right of access to documents" provides that "[a]ny citizen of the Union, and any natural or legal person residing or having its registered office in a Member State, has a right of access to documents of the institutions, bodies, offices and agencies of the Union, whatever their medium". When the 25 Member States draw up a new Constitutional Treaty, this article should be revised to extend FOI protection to any natural or legal person. ${ }^{166}$

At present, the Council and Commission are free to review their experiences in FOI law implementation. In addition, Article 17(2) of the Regulation aims to ensure that the objectives of the Regulation will not be compromised in implementation of this new legal framework. In other words, under Article 17(2), the Commission was under an explicit obligation to consider what can be learned in the enforcement of the

\footnotetext{
165 The Commission does not, however, detail the basis on which it makes this prediction. The Commission, n. 2 above, at 44.

${ }^{166}$ See 5.2.1 above.
} 
Regulation. However, the Commission has not carefully considered the limits of the present FOI regime and the judgments delivered at the third stage of the EU FOI evolution.

The results of our analysis, which differ from the views expressed in the Commission's report, indicate that there is significant room for improvement in the current FOI system. The EU legislator should consider, in particular, addressing the controversy concerning the principle of proportionality and the non-disclosure rule. Major revisions should not merely concern the issues relating to that possible extension of the Regulation to other institutions, bodies, and agencies. How the non-disclosure provision can be reasonably amended, and how the principle of proportionality can be expressly incorporated into the Regulation, must also be taken into account.

\subsubsection{The non-disclosure rule}

The Petrie and Interporc II judgments indicate that the authorship rule was incompatible with the principle of widest possible access set out in the Code of Conduct. ${ }^{167}$ The phrase "widest possible access" indicates that, under this principle, there is no space for an absolute exception. The authorship rule however constitutes an exception as such because the Council and Commission have no say on the disclosure of information originating from third parties. This incompatibility posed a major threat to the previous EU FOI regime, which is presumably the reason why the authorship rule is not included in the 2001 Regulation.

${ }^{167}$ See $\mathbf{5 . 3}$ and $\mathbf{5 . 5}$. 
Article 4(5) of the Regulation is a new exception different from the authorship rule set out in the Code of Conduct. One of the most important features of Article 4(5) is that, under this provision, the Council, the Commission, and the Parliament are not bound by the requests from the Member States. ${ }^{168}$ When an institution decides on releasing a document, which is drawn up by a Member State and held by the institution, the role of the Member State is merely supplementary. The documents governed by Article 4(5) are those sent to one or more of the Council, the Commission, and the Parliament, which concern the operation of the institutions. At the Community level, it is plausible to make the institutions decide on disclosure of this kind of information. In the Messina judgment, the CFI however ignored the feature of Article 4(5), holding that the refusal appeared to be legally justified because Italy objected to the request at issue. In the Internationaler Tierschutz-Fonds case, the Commission refused a non-governmental organisation's request for access to certain documents originating from the German government, the CFI reiterated its view in Messina and stated that "a request made by a Member State under Article 4(5) does constitute an instruction to the institution not to disclose the document in question" (emphasis added). ${ }^{169}$ These opinions could trigger future disputes over the invocation of the non-disclosure rule.

In addition, to prevent the institutions from broadly interpreting this exception and systematically refusing access to the information originating from the Member States, the EU legislator should consider revising the Regulation, requiring that the institutions take careful account of the principle of proportionality when the Member States oppose to releases of information.

\footnotetext{
168 See 5.7.2. Case T-76/02, Mara Messina v. Commission [2003] ECR II-3203.

169 paras. 57 and 58, Case T-168/02, IFAW Internationaler Tierschutz-Fonds gGmbH v. Commission [2004] ECR 0000.
} 


\subsubsection{The principle of proportionality}

The CFI introduced the principle of proportionality into the area of freedom of information in the Hautala judgment. It was, however, unclear as to how this principle should be applied by the Council and Commission. What the CFI stated in Hautala was that "Article 4(1) of Decision 93/731 must be interpreted in the light of the principle of the right to information and the principle of proportionality" (emphasis added) ${ }^{170}$ Did the institutions bear the same obligation when invoking any exceptions laid down in the Code of Conduct? The Courts did not answer this question in Hautala, Kuijer, or Mattila. Although they were responding to challenges relating to specific exceptions, one might have expected some guidance as to whether such a key principle as proportionality had a wider application in this context. Both the Council and Commission were uncertain about when the Court would intervene. This was probably the reason that, in the Mattila case, the two institutions failed even to think of this principle when refusing Mr. Mattila's requests. At present, a much more important issue concerns the relation between the principle of proportionality and the exceptions set out in the 2001 Regulation.

Hautala, Kuijer, and Mattila judgments, delivered between 1999 and 2004 have two common features. First, the public interest exception relating to international relations was invoked in all three cases. Second, in addressing all three disputes, the ECJ was of the view that the Council, the Commission, or both institutions' refusals of partial access were inappropriate. As to the first characteristic, the importance of the principle of proportionality should be emphasised not only in circumstances where the international relations exception is invoked. It bears noting that, in Mattila,

${ }^{170}$ para. 87 , n. 34 above. 
the ECJ annulled the Council and Commission refusals mainly because the institutions failed to consider the principle of proportionality in their refusals, which deprived the applicant of his right to a fair hearing. As regards accomplishment of this purpose, now the three institutions should apply this principle when invoking any of the exceptions set out in the Regulation. This is because, whenever a refusal of a request is made, the applicant would immediately need to examine the reasoning behind the denial, irrespective of which exception is invoked. As to the second common feature, the Courts appeared to have limited the proportionality review to determining whether partial access should be granted. The use of the proportionality test should be extended to deciding whether full access should be granted.

It can be concluded that, the Court should put the Council, the Commission, and the Parliament under a stricter obligation as to the application of the principle of proportionality. This principle should be incorporated in an explicit fashion into the Regulation to improve the FOI protection in the Union. We suggest that the legislator consider amending the 2001 Regulation, requiring that, first, this principle apply when any of the exceptions in the legislation are involved, and, second, this application be expressly stated in a decision that approves or refuses a request.

\subsubsection{The public interest exceptions relating to investigations, inspections, and court proceedings}

As to the public interest exceptions relating to investigations, inspections, and court proceedings, the CFI stated in Petrie that the Commission was entitled to invoke these exemptions to secure an amicable resolution of the dispute between the 
Commission and the Member State concerned, before the Community court delivers a judgment. In Interporc II, the CFI altered its opinion, a change then endorsed by the ECJ. The CFI stated that "the expression 'court proceedings' must be interpreted as meaning that the protection of the public interest precludes the disclosure of the content of documents drawn up by the Commission solely for the purposes of specific court proceedings". ${ }^{171}$ Court proceedings are designed to ensure the enforcement of EC law rather than an amicable resolution of disputes. It is, therefore, inappropriate to say that the public interest exceptions relating to investigations, inspections, and court proceedings are intended mainly to guarantee an amicable resolution.

Under Article 4(2) of the Regulation, the Council, the Commission, and the Parliament must refuse access to a document where disclosure would undermine the protection of, inter alia, "court proceedings and legal advice", and "the purpose of inspections, investigations and audits", unless there is an overriding public interest in disclosure. The Court's view in Interporc II should be reflected in these provisions. We suggest that the EU legislator revise these provisions, requiring that only the protection of the right to a fair hearing, and the privileges of lawyers, namely major purposes of court proceedings, inspections, and investigations, can be relied on to justify refusals.

\subsubsection{Further steps}

It is time to consider what further steps are required to improve EU FOI protection,

171 para. 40 , n. 108 above. 
particularly given that the status of the Constitutional Treaty remains uncertain. Articles I-50, II-102, Ш-399 of this Treaty were designed to bring about an extension of FOI protection. ${ }^{172}$ What is the difference between these articles and Article 255 EC with respect to the scope of public scrutiny? Under Article $255 \mathrm{EC}$, the public is capable of scrutinising the EC executive and operation of the legislature through access to documents. Under Articles I-50, II-102, Ш-399, a wide range of administrative, legislative, executive, and judicial functions of the Union is put under democratic scrutiny through the exercise of freedom of information.

Secondly, it is of interest to compare the position of Article 255 in the EC Treaty to that of Article II-102 in the Constitutional Treaty. Article 255 EC is in Chapter 2 of the EC Treaty's Part V entitled "Provisions Common to Several Institutions". Article 255 EC does not emerge from either an EC Treaty section dealing with citizenship of the Union, or the general principles of the Union. Article II-102, however, is in Title V "Citizens' Rights" in Part II of the Constitutional Treaty entitled "The Charter of Fundamental Rights in the Union". Thus, the Constitutional Treaty recognises freedom of information as a fundamental right. Under a rule like Article II-102, it is

172 paras. 3 and 4 of Article I-50 provides that:

3. Any citizen of the Union, and any natural or legal person residing or having its registered office in a Member State shall have, under the conditions laid down in Part III, a right of access to documents of the Union institutions, bodies, offices and agencies, whatever their medium. European laws shall lay down the general principles and limits which, on grounds of public or private interest, govern the right of access to such documents.

4. Each institution, body, office or agency shall determine in its own rules of procedure specific provisions regarding access to its documents, in accordance with the European laws referred to in paragraph 3.

Article Ш-399 states that:

1. The institutions, bodies, offices and agencies of the Union shall ensure transparency in their work and shall, pursuant to Article I-50, determine in their rules of procedure specific provisions for public access to their documents. The Court of Justice of the European Union, the European Central Bank and the European Investment Bank shall be subject to the provisions of Article I-50(3) and to this Article only when exercising their administrative tasks.

2. The European Parliament and the Council shall ensure publication of the documents relating to the legislative procedures under the terms laid down by the European law referred to in Article I-50(3). 
difficult, though not impossible, for the EU authorities to claim that the general interest of the administration prevails over freedom of information.

The third issue concerns the beneficiaries of freedom of information. Under Article II-102, this right is reserved to "[a]ny citizen of the Union, and any natural or legal person residing or having its registered office in a Member State". This wording is exactly the same as that in Article 255 EC. Nevertheless, Article 2(2) of the 2001 Regulation states that the Council, the Commission, and the Parliament may "grant access to documents to any natural or legal person not residing or not having its registered office in a Member State". As we saw in 5.1.2 and 5.2.1, this provision leaves the institutions to address this issue individually. The Council and Commission amended their Rules of Procedure to extend this right to all natural and legal persons, irrespective of nationality, place of residence, or location of registered office. The Parliament makes their decisions case-by-case but not in a discriminatory way. These achievements should be reflected in a future Treaty and in the Regulation.

The fourth issue concerns Article II-71 of the Constitutional Treaty entitled "Freedom of expression and information" which provides that:

1. Everyone has the right to freedom of expression. This right shall include freedom to hold opinions and to receive and impart information and ideas without interference by public authority and regardless of frontiers.

2. The freedom and pluralism of the media shall be respected.

Although the citizens in France and the Netherlands in mid 2005 voted against the ratification of the Constitutional Treaty, an article such as Article II-71, designed to 
secure freedom of expression and freedom of media, could still be incorporated into a future Treaty. The issue here is whether an EU citizen is entitled to rely on such an article when defending his or her freedom of information. To answer this question requires the following analysis.

Article II-71(1) and the first two sentences of Article 10(1) of the Convention for the Protection of Human Rights and Fundamental Freedoms are exactly the same. In Leander v. Sweden, the European Court of Human Rights stated that "the right to freedom to receive information basically prohibits a Government from restricting a person from receiving information that others wish or may be willing to impart to him". ${ }^{173}$ It stressed that Article 10 ECHR did not confer on the individual a right of access to a register containing information on his personal position, nor does it embody an obligation on the Government to impart such information to the individual. ${ }^{174}$ It adopted the same approach in Gaskin v. United Kingdom. ${ }^{175}$ Nonetheless, this does not necessarily mean that an article like Article II-71 cannot be relied on to enhance FOI protection in the Union. It bears noting that the first two paragraphs of Article I-9 of the Constitutional Treaty provide that:

1. The Union shall recognise the rights, freedoms and principles set out in the Charter of Fundamental Rights which constitutes Part II.

2. The Union shall accede to the European Convention for the Protection of Human Rights and Fundamental Freedoms. Such accession shall not affect the Union's competences as defined in the Constitution. ${ }^{176}$

The European Court of Justice, therefore, could go beyond the case law of the

${ }_{173}$ para. 74, Leander v. Sweden (1987) 9 EHRR 433.

174 Ibid.

175 Gaskin v. United Kingdom (1989) 12 EHRR 36.

176 Emphasis added. 
European Court of Human Rights, broadly interpreting the scope of freedom to receive and impart information to guarantee better FOI protection in the Union.

The Community court could make such an interpretation after a future Treaty incorporates rules such as Articles II-71 and II-102 of the Constitutional Treaty. What difference could this opinion make as regards protection of freedom of information, a fundamental right in the Union? Broad interpretation of the scope of Article II-71 solidifies the foundation for the FOI protection. In this regard, FOI protection is based on not only Treaty provisions on right of access to documents but also those on freedom of expression and freedom of media. In other words, protection of freedom of information could in the future be enhanced by two other fundamental rights in the Union. Where the EU legislator agrees that Article II-71 of the Constitutional Treaty also forms part of the basis of EU FOI protection, the legislator could revise the 2001 Regulation to offer citizens and the media more information on the operation of the Union. Possible revisions include those narrowing the scope of exceptions to openness and new rules ensuring easier exercise of this right. These possible changes can be fully justified on the ground that they are not only in line with Articles I-50, II-102, Ш-399, which guarantee freedom of information, but also with Article II-71, which secures freedom of expression and freedom of media. Multiple fundamental right clauses, as a result, could help extend the scope of EU FOI protection, which would eventually enable citizens and the media to scrutinise the Union in a more proactive and effective manner. 


\section{PART III Alternative Methods of Guaranteeing Freedom of Information within the EU}

\section{Introduction}

The European Court of Justice has long endeavoured to guarantee freedom of information through careful consideration of the way in which the Council and Commission invoke the various exceptions to openness in the EU's FOI laws. Nonetheless, these efforts are not always sufficient to secure openness because not all the shortcomings of the FOI regime end up in disputes before the Court. What the Court has addressed are highly controversial refusals, considered absolutely unacceptable by the applicants. As to consideration of other problems regarding the FOI system, how this regime could be improved, and alternative mechanisms of complaint for those whose requests are refused, the European Parliament and the European Ombudsman have played pivotal roles. In other words, the role of these two institutions in guaranteeing this essential right differs significantly from that employed by the Court.

Certain achievements by the Parliament and the Ombudsman in furthering freedom of information have already been examined in previous parts of this study. For instance, the Parliament, which was the first Community institution to have its own policy on 
freedom of information, adopted an important Resolution in mid 1984. ${ }^{1}$ The Parliament also actively participated in the process of adopting the 2001 Regulation. ${ }^{2}$ What the Ombudsman has achieved in this field is also remarkable. For example, the Ombudsman Mr. Jacob Söderman played a central role in challenging the emphasis on excessive secrecy in the Commission draft of what was to become the 2001 Regulation, harshly criticising the proposal in $2000 .^{3}$ In Chapters 6 and 7, we turn to focus on the role of these two institutions after the Regulation came into force in December 2001.

\section{Incentives}

First, it is necessary to consider what has led the Parliament and Ombudsman to defend freedom of information. The reasons behind this defence will help us understand the roles these two institutions have played to date and could play in the future in this field. Only a few Community jurists have touched on this important issue. Among them is Professor Patrick Birkinshaw, who has said that "[t]he Ombudsman has in fact attacked secrecy in the EU with missionary zeal". ${ }^{4}$ The Parliament has also defended freedom of information with passion, but enthusiasm itself does not explain why these institutions have so rigorously tackled secrecy in the Union. What needs to be considered here are

\footnotetext{
1 This Resolution, and another relevant Resolution adopted by the Parliament in 1988 have been analysed in 2.1.

${ }^{2}$ The Parliament, whose opinions prevailed over the Commission proposal, adopted the Regulation jointly with the Council in May 2001. See 4.2.3.

${ }^{3}$ The Ombudsman was extremely unsatisfied with the "long and obscure" list of exceptions set out in the draft Regulation. See 4.2.1.

${ }^{4}$ P. Birkinshaw, Freedom of Information, The Law, the Practice and the Ideal $\left(3^{\text {rd }} \mathrm{edn}\right.$., London, Butterworths, 2001), 368.
} 
the advantages and disadvantages that accompany the Parliament and the Ombudsman's support for a liberal FOI system.

\section{A. Advantages}

With respect to the potential advantages, the Parliament and Ombudsman benefit much more from openness than the Council and Commission. The Ombudsman and the members of the Parliament are able to win a great deal of confidence from EU citizens through firm and continuous support for the FOI regime. The role of the Parliament is to represent the peoples of the Community and that of the Ombudsman is to reduce maladministration..$^{5}$ The defence of freedom of information by the two institutions corresponds well to their fundamental roles.

To be specific, as to the Parliament, its long term backing for the FOI regime expressly shows that in their capacity as directly elected representatives, the Members of the Parliament make a significant effort to extend an important right of the citizens. In addition, a liberal FOI regime helps the Parliament exercise, most importantly, democratic supervision over the operation of the Council and Commission in a more effective fashion. This is because narrowly drawn exceptions and flexible use of sensitive documents will definitely make it easy, not only for the public but also for the Parliament, to access the documents drawn up and received by the two institutions. For

\footnotetext{
${ }^{5}$ Article 189 EC makes it clear that the Parliament consists of "representatives of the peoples of the States brought together in the Community". As to the Ombudsman, Article 195(1) EC provides that:

The European Parliament shall appoint an Ombudsman empowered to receive complaints from any citizen of the Union or any natural or legal person residing or having its registered office in a Member State concerning instances of maladministration in the activities of the Community institutions or bodies, with the exception of the Court of Justice and the Court of First Instance acting in their judicial role. (emphasis added)
} 
instance, where the Parliament is entitled under the Regulation to make use of the sensitive documents drawn up or received by the Council and the Commission, the Parliament can be expected to scrutinise the running of the two other institutions more effectively. It bears noting that the power of the Parliament to control the Council has never been very effective. ${ }^{6}$ As regards the Ombudsman, its long term support for the FOI protection obviously constitutes part of its effort to uncover and reduce maladministration. $^{7}$

Nevertheless, the Council and the Commission do not seem to gain much from openness. As far as their political careers are concerned, the ministers attending meetings of the Council, as well as the members of the Commission, are unlikely to gain political capital through defending freedom of information.

\section{B. Disadvantages}

As to the possible disadvantages of such support, the Parliament and Ombudsman suffer much less than the Council and Commission under a liberal FOI regime. In fact, the former institutions have little to lose. First, one of the most important powers the Parliament possesses is to legislate jointly with the Council under the co-decision procedure. Under this procedure, it is impossible for the Parliament to adopt any legal

${ }^{6}$ Although the EU claims that the Parliament "monitors the work of the Council", what Members of the Parliament do is merely ask the Council written and oral questions, and the President of the Council attends the plenary sessions and takes part in important debates. The European Commission, How the European Union Works, a Citizen's Guide to the EU Institutions (Brussel, European Commission, 2003), 12.

7 This effort also enhances the social legitimacy of the Union. Dr. Roy Davis has noted that "the Ombudsman offers a credible alternative to the CFI, particularly when EU institutions refuse to grant access to documents in their possession; that this helps to ensure the social legitimacy of the EU". R. Davis, 'Quasi-Judicial Review: the European Ombudsman as an Alternative to the European Courts' (2001) 1 Web Journal of Current Legal Issues, http://webjcli.ncl.ac.uk/2000/issue1/davis1.html 
instrument alone behind closed doors. All the documents relating to a proposed measure subject to co-decision must be shared not only by the Parliament and Council but also the Commission where necessary, in the course of the so-called "trialogues". ${ }^{8}$ As the relevant information is fully shared during frequent organised contacts, there is no chance for the Parliament to keep any secrets within its office in order to gain certain institutional advantages. As the Parliament retains no confidential information under the co-decision procedure, this institution does not regard an increasingly liberal FOI law as a threat.

However, the Council and Commission might take the view that they have been suffering under the FOI regime. The main reason is straightforward, namely that numerous decisions made within the Council and Commission are not adopted under the co-decision procedure. This means that the decisions are not adopted in the triolagues noted above. For these two institutions, the secrecy that they have long practiced has always been considered essential to the decision-making process. Explicit and stringent FOI rules nonetheless could soon bring the days during which they have benefited from this secrecy to an end.

As regards the Ombudsman, it is not a decision-making institution. There is little interest that seduces the Ombudsman into keeping the inquiry-related information secret. At present, the information in the possession of the Ombudsman is not even covered by the 2001 Regulation. Nevertheless, it is necessary to keep a close eye on how the

\footnotetext{
${ }^{8}$ As Professor Alan Dashwood has said, under the co-decision procedure, "a measure can only be adopted if it receives the positive approval of both Parliament and Council, at first or second reading where the co-legislators act at arm's length, or after a joint text has been thrashed out by their representatives in a conciliation committee, with the Commission acting as honest brokcr" (emphasis added). Describing this negotiation as a "trialogue", he goes on to say that "indeed that is the name which has been given to the organized contacts which take place between the three institutions at the different stages in the passage of a measure which is subject to co-decision". A. Dashwood, "Issues of Decision-making in the European Union after Nice' in A. Arnull and D. Wincott (eds.), Accountability and Legitimacy in the European Union (Oxford, Oxford University Press, 2002), 23.
} 
Ombudsman will continue to contribute to FOI protection, given that the documents in his or her possession are likely to be covered by the FOI Regulation in the future. 


\section{6}

\section{The Role of the Parliament}

The incentives for adopting FOI legislation suggest that the following fact should not be very surprising: the 2001 Regulation governs information in the possession of the Council, the Commission, and the Parliament, but regarding the defence of freedom of information, the role of the Parliament can be seen to be distinct. First, the Parliament has long insisted on a liberal FOI law. Second, the implementation of the Regulation by the Parliament is much less controversial than that by the Council and Commission. Third, no court proceedings have been instituted against the Parliament by applicants after they have received its negative replies. What the Parliament has achieved shows that although the information it holds is covered by the Regulation, it considers itself to be a guardian of freedom of information within the Union.

We will analyse the position of the Parliament in this field mainly through examining a very important Resolution adopted by the Parliament in September 2003. In this instrument, the Parliament expresses critical and constructive views on the implementation of the Regulation. It addresses the following questions in detail, suggesting how the enforcement of the 2001 Regulation can be improved and how this legislation can be revised, though it should be noted that some of its suggestions are of an experimental nature.

\footnotetext{
1 European Parliament resolution on public access to Parliament, Council and Commission documents (implementation of Regulation (EC) No 1049/2001 in the year 2002) (2003/2022(INI)), http://www2.europarl.eu.int/omk/sipade2?PUBREF=-//EP//TEXT+TA+P5-TA-2003-0413+0+D $O C+X M L+V 0 / / E N \& L=E N \& L E V E L=3 \& N A V=S \& L S T D O C=Y$
} 
(1) What standards does the Parliament plan to adopt in applying the 2001 Regulation to the documents it draws up and receives?

(2) In the FOI area, how does the Parliament plan to exercise its newly-acquired right to seek review of the acts of the Community institutions under Article 230 EC?

(3) How should the Parliament address the controversy concerning "systematic refusals" and what action, if any, should it take in order to reduce such denials of access?

(4) How can enhanced interinstitutional cooperation be achieved in this area? What practical measures could be taken at the interinstitutional level for the reorganisation of the coding process, production, filing and distribution of information?

\subsection{The adoption of the highest standards}

\section{in pursuit of transparency}

In this Resolution, the Parliament urges itself and its services to apply the highest standards with respect to transparency, advising "in particular Committee secretariats to ensure up-to-date information about their workings on their websites and to operate in full transparency". 2 This statement indicates the Parliament is aware of the fact that although its performance has been much more remarkable than that of

${ }^{2}$ para. 6, n. 1 above. 
the Council and Commission, it has not yet met the highest standards possible. In fact, the publication of this Resolution was itself a cause of some embarrassment. The measure was adopted by the Parliament on 23 September 2003, but it was not available on the website of the Parliament register until seven months later on 24 May $2004^{3}$

\subsection{Exercise of the right to seek judicial review under}

\section{Article 230 EC}

The enhancement of the Parliament's power must be carefully considered when examining the role of this institution in the FOI field. Thanks to the co-decision procedure introduced by the Treaty of Amsterdam, the Parliament was able to participate actively in the course of adoption of the 2001 Regulation and to insist on its ideals about FOI protection. Nonetheless, what the Parliament could achieve later in 2002 was relatively limited. Making comments in a report on the implementation of the Regulation during that year was one of the few ways it could contribute to this area. ${ }^{4}$ When it comes to FOI disputes before the Community courts, the Parliament is entitled to intervene in support of a party in court proceedings. ${ }^{5}$ In fact, the Parliament did not hesitate in doing so in the initial development in this area. For

\footnotetext{
${ }^{3}$ n. 1 above.

4 The Parliament, Report on Public Access to Parliament, Council and Commission Documents (Implementation of Regulation 1049/2001/EC in the year 2002) (2003/2022(INI)), 11 September 2003, Final A5-0298/2003.

5 Article 40(1) (former Article 37(1)) of the Statute of the Court of Justice provides that "Member States and institutions of the Communities may intervene in cases before the Court".
} 
instance, it demonstrated firm support for better FOI protection when intervening in the 1995 Carvel and 1996 Netherlands cases. ${ }^{6}$

A significant change could be seen when the Treaty of Nice came into force in late December 2002. The first two paragraphs of Article $230 \mathrm{EC}$ provide that:

The Court of Justice shall review the legality of acts adopted jointly by the European Parliament and the Council, of acts of the Council, of the Commission and of the ECB, other than recommendations and opinions, and of acts of the European Parliament intended to produce legal effects vis-à-vis third parties.

It shall for this purpose have jurisdiction in actions brought by a Member State, the European Parliament, the Council or the Commission on grounds of lack of competence, infringement of an essential procedural requirement, infringement of this Treaty or of any rule of law relating to its application, or misuse of powers. (emphasis added)

As the Parliament has been granted full locus standi to seek judicial review of Community acts under Article 230 EC, it is expected to defend freedom of information before the Community courts rigorously. What it can now contribute goes far beyond merely monitoring how the Regulation is implemented.

Nonetheless, the Resolution indicates that the Parliament has not fully realised the potential opened up by Nice. The Parliament states in the Resolution that:

[T] he European Parliament, the Council and the Commission, which seem to refuse systematically all applications for legal opinions, which could also be against the spirit and the letter of Regulation (EC) No 1049/2001; in this connection, and following the entry into force of the Treaty of Nice which

${ }^{6}$ Case T-194/94, John Carvel and Guardian Newspapers v. Council of the European Union [1995] ECR II-2769; Case C-58/94, Netherlands v. Council [1996] ECR I-2169. 
gives to the European Parliament a general right to appeal, requests its Committee on Legal Affairs and the Internal Market to discuss the European Parliament's participation in the T-84/03 [Turco v. Council] proceedings. ${ }^{7}$ (emphasis added)

This statement is potentially quite confusing because it seems to blur the right to seek review under Article $230 \mathrm{EC}$, as amended, with the right to participate in cases as an intervener, a right that the Parliament has long possessed. ${ }^{8}$ What the Parliament is entitled to do is much more than intervention in the Turco case. In response to systematic refusals, the Parliament may bring actions under Article 230 EC to seek annulment of the acts that systematically refuse access to information. It should be noted, however, that as the Parliament admitted in the statement that it is also among the institutions that systematically refuse access to legal opinions, we should keep a watchful eye on whether it will employ this new right regularly.

\subsection{Systematic refusals}

\subsubsection{Types}

Systematic refusals based on certain exceptions listed in the 2001 Regulation or on

\footnotetext{
${ }^{7}$ Point 6 of paragraph 4. Case T-84/03, Maurizio Turco v. Council [2004] ECR II-0000. In this case, Maurizio Turco sought the annulment of a Council decision partially refusing access to certain documents appearing on the agenda of the Justice and Home Affairs Council meeting of 14 and 15 October 2002. The Parliament eventually did not intervene in support of the applicant in the court proceedings.

${ }^{8}$ It was once unclear whether the Parliament was within the meaning of the phrase "institutions" in former Article 37(1) (now Article 40(1) of the Statute of the Court of Justice. For text of this provision, see n. 5 above. The Court gave a positive answer in the 1980 Frères and Maizena judgments. Case 138/79, SA Roquette Frères v. Council [1980] ECR 3333, and Case 139/79, Maizena GmbH v. Council [1980] ECR 3393. See also H. Schermers, Judicial Protection in the European Communities ( $5^{\text {th }}$ edn., Deventer, Kluwer Law and Taxation Publishers, 1992), 486.
} 
no exemption whatsoever have posed a major threat to the entire EU FOI regime. According to the Resolution, the Parliament wishes to take effective steps to reduce such refusals. It considers that the following situations concerning the decision-making process are unsatisfactory. It states that:

[The Council does not] permit the identification of the positions of the various national delegations at the time of the decision-making process: the removal of this information, which is essential to the supervision of national government positions, is against the spirit and the letter of the Regulation (EC) No $1049 / 2001$, which permits exceptions based on the content of a document (Article 4(7)) and not on the basis of the activity of national delegations when acting as a component of the Council. ${ }^{9}$

It is uncertain whether the Council is of the opinion that the removal of the crucial information is permitted under Article 4(7), but it is absolutely clear that this total restriction on the identification of the positions taken during the decision-making process runs counter to the Regulation. On the one hand, the Council is not entitled to remove the information, because these denials of access are not based on any exceptions laid down in the Regulation. These refusals seem to have been made on the mere presumption that certain public interests are likely to be undermined. On the other hand, these removals are not determined by the Council on a case-by-case basis.

Secondly, the Parliament said in the Resolution that the Council "seems to systematically refuse applications for documents concerning public security on the basis of Article 4(1) of the Regulation". 10 Thirdly, "the Parliament, the Council, and

\footnotetext{
${ }^{9}$ Point 4 of paragraph 4, n. 1 above. According to Article 4(7) of the Regulation, "[t] he exceptions as laid down in paragraph 1 to 3 shall only apply for the period during which protection is justified on the basis of the content of the document".

${ }^{10}$ Point 5 of paragraph $4, n$. 1 above.
} 
the Commission, seem to refuse systematically all applications for legal opinions, which could also be against the spirit and the letter of Regulation (EC) No $1049 / 2001$ ", according to the Resolution. ${ }^{11}$

In addition, the Commission interpretation of the Regulation "is questionable when it systematically denies citizens access to correspondence from the Member States in the context of infringement proceedings once the proceedings have been completed or suspended". ${ }^{12}$ The Parliament went on to say that the Commission "should, instead, carry out an independent assessment of the matter on the basis of presumption of accessibility; and reminds the Commission that applications for access to documents must be considered on a case-by-case basis". ${ }^{13}$

\subsubsection{Remedies}

All these systematic refusals have a destructive impact on the EU FOI regime as they run against the very basis of the Regulation, namely the principle of widest possible access. We must then go on to consider what can be done to address this crisis. Is it necessary to revise the 2001 Regulation to address this threat? It should be reiterated that explicit incorporation of the principle of proportionality into the Regulation could be an effective method to prevent the systematic refusals. ${ }^{14}$

An alternative, which is not mutually exclusive with the express inclusion of the principle of proportionality, is put forward by the Parliament in this Resolution. The

\footnotetext{
11 Point 6 of paragraph 4, n. 1 above.

12 Point 12 of paragraph 4, n. 1 above.

${ }_{13}$ Point 12 of paragraph 4 , n. 1 above.

14 See 5.8.3.
} 
Parliament calls for a reduction in the vagueness of the various exceptions in the Regulation. This lack of definition has left the three institutions with enormous space for interpreting the exemptions. It cannot be discounted that the lack of express and practical definitions has been used to refuse access systematically. Therefore, in the final part of this Resolution, the Parliament suggests that the Regulation needs clarification "to avoid varying interpretations by the institutions (legal opinions, positions of national delegations and other issues mentioned in paragraph 4 etc. [of this Resolution] including definitions on the use of certain concepts such as 'public interest"”.

Nonetheless, it is much easier to put forward such an idea than to draft a list of explicitly-defined exceptions. In fact, the Parliament puts forward this suggestion in the Resolution without touching on how the definitions should be proposed. It bears noting that the scope of the various exceptions in the Regulation cannot be easily drawn through studies of relevant legislation within or outside the Union.

We will take the exception relating to privacy as an example to explain our view. Under Article 4(1)(b) of the Regulation, the institutions must refuse access to a document where disclosure would undermine the protection of "privacy and the integrity of the individual, in particular in accordance with Community legislation regarding the protection of personal data".

The legislation at the European level is very open ended. For instance, Article 8 of the Convention for the Protection of Human Rights and Fundamental Freedoms entitled "Right to respect for private and family life" provides that:

1. Everyone has the right to respect for his private and family life, his home and his correspondence; 
2. There shall be no interference by a public authority with the exercise of this right except such as is in accordance with the law and is necessary in a democratic society in the interests of national security, public safety or the economic well-being of the country, for the prevention of disorder or crime, for the protection of health or morals, or for the protection of the rights and freedoms of others.

As regards respect for private and family life, Article II-67 of the Constitutional Treaty states that "[e]veryone has the right to respect for his or her private and family life, home and communications". As to the protection of personal data, Article II-68 of the Treaty provides that:

1. Everyone has the right to the protection of personal data concerning him or her.

2. Such data must be processed fairly for specified purposes and on the basis of the consent of the person concerned or some other legitimate basis laid down by law. Everyone has the right of access to data which has been collected concerning him or her, and the right to have it rectified.

3. Compliance with these rules shall be subject to control by an independent authority.

These articles recognise privacy to be a fundamental right, but they do not offer the definition or the scope of this phrase. Therefore, they will not be useful (even if the Constitutional Treaty were ultimately to be adopted by all the Member States) when the EU legislator seeks to clarify the scope of the privacy exception in the 2001 Regulation.

Approaches to the protection of privacy at the domestic level vary considerably, with countries such as Germany having a developed concept founded on human dignity, while in other countries, such as the U.K., privacy law is still at a stage of 
development. It may therefore be more helpful in this context to look specifically at domestic FOI laws. What can we learn from the domestic FOI laws within or outside the Union to help delimit the scope of this concept? Two domestic FOI regimes that adopt very different approaches to guaranteeing privacy, without compromising freedom of information, may help us better understand the potential problems that could arise in this endeavour. In the U.S. FOI system, the scope of the exception relating to privacy is narrowly drawn. Subsection (b)(7)(B) of the 2002 U.S. Freedom of Information Act provides that this Act does not apply to the matters in "personnel and medical files and similar files the disclosure of which would constitute a clearly unwarranted invasion of personal privacy" (emphasis added). ${ }^{15}$ In Scotland, although the scope of the privacy exception is drawn narrowly as well, a different approach is adopted. The boundary of the exemption concerning personal information is sketched in the Freedom of Information (Scotland) Act 2002 through heavy reliance on certain definitions already available in the Data Protection Act 1998 in the U.K. ${ }^{16}$

With respect to the clarification of the scope of the privacy exception, on the one hand, the U.S. approach is straightforward, but this does not mean that it would

\footnotetext{
${ }^{15}$ The Freedom of Information Act, 5 U.S.C. $\S 552$.

${ }^{16}$ For instance, under the first two subsections of Section 38 entitled "Personal information", information is exempt information if it constitutes personal data and, inter alia, the following condition is met:

(a) in a case where the information falls within any of paragraphs (a) to (d) of the definition of "data" in section 1(1) of the Data Protection Act 1998 (c.29), that the disclosure of the information to a member of the public otherwise than under this Act would contravene-

(i) any of the data protection principles; or

(ii) section 10 of that Act (right to prevent processing likely to cause damage or distress); and

(b) in any other case, that such disclosure would contravene any of the data protection principles if the exemptions in section $33 \mathrm{~A}(1)$ of that Act (which relate to manual data held) were disregarded.

No definition of the phrase "personal information" can be found in the Freedom of Information (Scotland) Act, and we should look at the Data Protection Act 1998. The former is, therefore, not very useful in drawing the scope of the privacy exception.
} 
help to realise the objective of the Parliament, namely to avoid varying interpretations by itself and the two other institutions. This is because the terms "clearly unwarranted invasion of personal privacy" could be read in various different ways by the public and the institutions. On the other hand, the Scottish method seems to have reduced the vagueness of the privacy exception through employment of the definitions in the Data Protection Act 1998. It seems that the Scottish approach could thus be the better choice for the Union because it is more detailed, but in fact it does not reduce the vagueness, because we have found no definition of "personal data" at all in the Freedom of Information (Scotland) Act.

Another concern is that the personal data protection law at the Union level is much more complicated than that at the domestic level. To introduce the definitions in the EU data protection law into the 2001 Regulation is not an easy task for the following reasons. First, there are four major legal instruments governing personal data protection rather than one data protection law at the domestic level. ${ }^{17}$ Secondly, one of the most crucial legal terms in Article 4(1)(b) of the Regulation, namely "privacy", is not even defined in any of the four legal instruments in the Union, while

${ }^{17}$ At the Union level, the fundamental rules on data protection are set out in:

(1) Directive 95/46/EC of the European Parliament and of the Council of 24 October 1995 on the protection of individuals with regard to the processing of personal data and on the free movement of such data [1995] OJ L281/31;

(2) Directive 97/66/EC of the European Parliament and of the Council of 15 December 1997 concerning the processing of personal data and the protection of privacy in the telecommunications sector [1998] OJ L24/1;

(3) Regulation (EC) No 45/2001 of the Parliament and of the Council of 18 December 2000 on the protection of individuals with regard to the processing of personal data by the Community institutions and bodies and on the free movement of such data [2001] OJ L8/1;

(4) Directive 2002/58/EC of the European Parliament and of the Council of 12 July 2002 concerning the processing of personal data and the protection of privacy in the electronic communications sector (Directive on privacy and electronic communications) [2002] OJ C201/37.

The case law in the field of data protection in the Union mainly concerns Directive 95/46. See Joined cases C-465/00, C-138/01 and C-139/01, Rechnungshof v. Österreichischer Rundfunk and others and Christa Neukomm and Joseph Lauermann v. Österreichischer Rundfunk [2003] ECR I-4989, and Case C-101/01, Criminal Proceedings against Bodil Lindqvist [2003] ECR I-12971. 
the most relevant phrase in the EU data protection legislation is "personal data". ${ }^{18}$

This means that the definitions in the EU data protection law are not very useful, as far as the clarification of the privacy exception in the Regulation is concerned.

Our analysis concerns only one of the various exceptions in the Regulation, but it indicates that it will be extremely difficult, though not absolutely impossible, for the EU legislator to reach consensus on how all the boundary should be drawn.

\subsection{Cooperation}

In its Resolution, the Parliament says the institutions have taken the internal measures for the reorganisation of the coding process, production, filing and distribution of documents. ${ }^{19}$ Nonetheless, "at the interinstitutional level almost everything still remains to be done". ${ }^{20}$ In fact, although the interinstitutional committee has been set up to meet the requirement set out in Article 17(2) of the Regulation, no significant achievements have so far been made at the committee meetings. As regards the interinstitutional efforts, the Parliament puts forward a

\footnotetext{
${ }^{18}$ For instance, Article 2(a) of the Regulation 45/2001 provides that " 'personal data' shall mean any information relating to an identified or identifiable natural person hereinafter referred to as 'data subject'; an identifiable person is one who can be identified, directly or indirectly, in particular by reference to an identification number or to one or more factors specific to his or her physical, physiological, mental, economic, cultural or social identity", n. 17 above. See also European Data Protection Supervisor, Public Access to Documents and Data Protection, Background Paper Series Number 1 (Brussels, European Data Protection Supervisor, 2005). This document, which reflects the opinion of the European Data Protection Supervisor on the relationships between public access to documents and data protection in the Union, addresses the main issues relating to freedom of information and privacy individually before focusing on their intersection.

${ }_{19}$ para. $7, \mathrm{n} .1$ above. It says these measures make it possible to identify the authors, the nature of the document and other information necessary for the traceability of documents within each institution.

${ }^{20}$ para. 7, n. 1 above.
} 
number of suggestions in the Resolution. Among them are three worth thorough consideration.

\subsubsection{Sensitive documents}

The Parliament suggests establishing "one set of rules on the treatment of confidential documents putting all institutions on the same footing as regards granting each other access". ${ }^{21}$ It bears noting that the information categorised as sensitive documents is unavailable not only to the public but also to the other EU institutions, agencies, and bodies. This plan reveals that the Parliament needs access to the sensitive documents held by the Council and Commission. The Parliament, therefore, wishes to have the restriction on the availability of the sensitive documents partially relaxed. The Council and Commission, however, might not be willing to agree with the Parliament. This is mainly because the Parliament has not produced any sensitive documents following the enforcement of the 2001 Regulation, while the Council either produced or received 250 such documents in $2002 .^{22}$ The number of sensitive documents soared in 2003 by 63 percent to 399, according to the 2003 Council Report. ${ }^{23}$ The Commission in 2002 produced and received an unknown

\footnotetext{
${ }^{21}$ Point 5 of para. 15, n. 1 above.

22 According to a report it published in September 2003, the Parliament in 2002 "neither drew up nor received any sensitive document". The Parliament, n. 4 above, at 12. Between 3 December 2001 and 31 December 2002, 12 "SECRET UE" and 238 "CONFIDENTIEL UE" documents originated from the Council or other sources, in which only 77 of them were recorded by the institution's register, according to last paragraph of Part I of the 2002 Council report on implementation of the 2001 Regulation. The Council, Council Annual Report on Access to Documents - 2002 (Brussels, the Council, April 2003), http://register.consilium.eu.int/utfregister/frames/introfsEN.htm.

${ }_{23}$ The Council, Council Annual Report on Access to Documents - 2003 (Brussels, the Council, April 2004), http://ue.eu.int/uedocs/cmsUpload/RapAnCons.en03.pdf, 11.
} 
number of sensitive documents. ${ }^{24}$ In 2003, it drew up 25 sensitive documents. ${ }^{25}$ We cannot rule out the possibility that the Parliament could draw up or receive such information in the future, but it is almost certain that the two other institutions would feel that they "lose" much more than the Parliament if this proposal is adopted.

\subsubsection{Interinstitutional coding system}

The Parliament states that the institutions have not yet established "a general system of interinstitutional coding, both for the types of documents and for the decisional procedures to which they refer (including the procedures in which the EP is not associated)" ${ }^{26}$ Is this a new system or an existing one in the Union? If the phrase "interinstitutional coding system" refers to the mechanism that helps us locate the information drawn up by the EU institutions, it is then inappropriate to say that a general system of interinstitutional coding has never been established within the Union. The Official Journal and related websites can certainly be regarded as such a system. Nevertheless, what the Parliament here envisages seems to be the setting up of a more advanced coding system, which would make it much easier for not only

\footnotetext{
${ }^{24}$ In its 2002 report on implementation of the Regulation, the Commission only says that among the three categories of documents presently covered by the register (the COM, C and SEC series of 2001 and 2002) there are no sensitive documents, European Commission, Report from the Commission on the Application in 2002 of Regulation (EC) No 1049/2001 of the European Parliament and of the Council regarding Public Access to European Parliament, Council and Commission documents, $\operatorname{COM}(2003) 216$ final, (Brussels, European Commission, 29 April 2003), http://europa.eu.int/smartapi/cgi/sga_doc?smartapi!celexapi!prod!CELEXnumdoc\&lg=EN\&nu mdoc $=52003$ DC0216\& model $=$ guichett, 7 .

${ }^{25}$ European Commission, Report from the Commission on the Application in 2003 of Regulation (EC) No 1049/2001 of the European Parliament and of the Council regarding Public Access to European Parliament, Council and Commission documents, COM(2004) 347 final, (Brussels, European Commission, 30 April 2004), http://europa.eu.int/eur-lex/lex/LexUriServ/site/en/com/2004/com2004_0347en01.pdf, 7 .

${ }^{26}$ Point 1 of para. 7, n. 1 above.
} 
the public, but also those working for the Union, to locate information relating to any interinstitutional decision making processes. We believe that this proposed scheme would be particularly helpful for those who are unfamiliar with the decision-making processes in the Union. For instance, those interested in how the 2001 Regulation was adopted might not be aware which institutions had participated in the course of this legislation. The proposed interinstitutional coding system is expected to assist them to locate all the relevant information prepared by the Commission, the Council, and the Parliament prior to the adoption of this legislation.

\subsubsection{An interinstitutional register?}

The Parliament states that all three institutions "seem to have problems with the operation of the registers". ${ }^{27}$ It therefore "requests increased efforts to improve them and also to assist citizens asking for documents, including increased interinstitutional cooperation on this issue in order to exchange best practice and the examination of the idea of setting up an interinstituional help desk, especially in relation to unspecific requests for documents" (emphasis added). ${ }^{28}$ In the concluding section of the Resolution, the Parliament further suggests "amending Article 12 of the Regulation to provide for the setting-up of a single interinstitutional register for procedures in which more than one institution is involved' (emphasis added). ${ }^{29}$

These proposals, which could bring revolutionary changes to the present EU

\footnotetext{
${ }^{27}$ Point 14 of para. 4, n. 1 above.

28 Point 14 of para. $4, \mathrm{n} .1$ above.

29 Point 3 of para. 15, n. 1 above. Article 12 concerns direct access in electronic form or through a register.
} 
FOI regime, are contentious for the following reasons. First of all, it is unclear whether the Parliament wishes to set up two more agencies, i.e. the single interinstitutional register and the interinstitutional help desk, or whether the Parliament hopes to have only one new agency -- a single interinstitutional register that plays the role of an interinstitutional help desk and has a number of other functions. Secondly, the Parliament does not elaborate why unspecific requests for documents would be better dealt with by an interinstitutional help desk than by the individual institutions that receive the applications. We believe that unspecific requests for documents can be appropriately addressed by the institutions receiving them through their registers' communications with the applicants and with the other institutions, agencies, and bodies concerned. As it is doubtful whether the setting-up of an interinstitutional register could effectively reduce the difficulty that has arisen between the three institutions, it is necessary to point out that the setting-up of such a new public register would presumably be a waste of administrative resources.

\subsection{Conclusion}

The Community court secures freedom of information in a relatively passive manner, in that it acts only where there is a FOI dispute before it. By contrast, under Article 230 EC, the Parliament now has the capability to be proactive in this area to seek reform. In doing so, the Parliament does not risk losing the benefits of secrecy enjoyed by the Council and Commission. The Resolution that we have examined in 
this chapter is the most important policy statement to date by the Parliament concerning the future of FOI protection. The Council and Commission should address the issues raised in this Resolution when considering amending the 2001 Regulation.

The Commission believes that it is unnecessary to present a proposal for revision of the 2001 Regulation. ${ }^{30}$ In its Resolution, however, the Parliament advises on how the enforcement of the Regulation can be improved and on how the legislation can be revised. The efforts made by the Parliament to improve the present EU FOI regime are undoubtedly significant, but certain suggestions of an experimental and even revolutionary nature need careful reconsideration.

The Parliament states that it is unsatisfied with the systematic refusal of requests for access to the following information:

(1) The information identifying the positions of the various national delegations at the time of the decision-making process;

(2) The documents concerning public security;

(3) The documents relating to legal opinions;

(4) The correspondence from the Member States in the context of infringement proceedings once the proceedings have been completed or suspended.

Our analysis demonstrates that it will be particularly difficult for the EU legislator to reach a consensus on how all the exceptions in the Regulation should be clearly defined. The Courts have carefully considered the scope of certain exceptions in a number of judicial decisions, but, unfortunately, the objective of the Parliament to set

30 See $\mathbf{5 . 8}$. 
out explicit definitions remains beyond reach. A more practical response to this great challenge would be to incorporate expressly the principle of proportionality into the Regulation, and to have the relevant judicial decisions and the major domestic FOI laws with regard to the scope of the exceptions reflected in the Regulation.

As to the calls of the Parliament for interinstitutional cooperation, first, the Council and Commission may not be willing to share with the Parliament the sensitive documents they have drawn up and received. The key reason is that the Parliament has never drawn up or received any sensitive documents subsequent to the 2001 Regulation coming into force, but the Council and Commission have hundreds. For the latter two institutions, to share the sensitive documents would be to help enhance the Parliament's power to exercise democratic supervision over them. Second, the plans concerning the setting up of an interinstitutional register can be questioned since its functions could overlap with those of the separate public registers of the Council, the Commission, and the Parliament. Our view is that each of the registers of the three institutions should exercise the functions of the interinstitutional register and interinstitutional help desk. It should be noted that under Article 1 of the Regulation, one of the three major purposes of the legislation is to "promote good administrative practice on access to documents". There are no grounds for denying that interinstitutional cooperation falls within the scope of "good administrative practice".

However, although there is no need for the interinstitutional register, the need for enhanced cooperation between various public authorities at the Union level is absolutely imperative. Under Article II-102 of the Constitutional Treaty, the public has a right of access to documents of the institutions, bodies, offices and agencies of the Union. Although the status of this Treaty remains uncertain, an extension of FOI 
protection as such should be incorporated into a revised or future Treaty and thus into the FOI Regulation. In this regard, a general scheme of cross public authorities coding would be very useful. Making use of such a system, individuals will find it much easier to locate all the public information relating to a decision, though they may be unfamiliar with which institutions, bodies, or agencies are required by law to participate in the adoption of this decision. Without this proposed system, it will be extremely difficult for those interested in a decision to determine which public authorities are involved in the decision-making process. This means that they may waste a lot of time and remain uncertain about whether they have obtained all the information available concerning that decision. 


\section{7 \\ The Role of the European Ombudsman}

This chapter analyses the role played by the European Ombudsman after the 2001 Regulation came into force. We will consider the mandate of the Ombudsman and relevant procedural issues before examining the efforts made by the Ombudsman to advance FOI protection. Attention will, in particular, be drawn to the contradictory views of the Ombudsman and the three other Community institutions, i.e. the Council, the Commission, and the Parliament, in relation to the exceptions to openness.

\subsection{The mandate of the European Ombudsman}

We will, first, consider the powers of the Ombudsman and the relationship between these powers and FOI protection. Second, we will seek to clarify some of the uncertainties surrounding the overlap between the mandate of the Ombudsman and the jurisdiction of the Community court.

\subsubsection{The powers of the Ombudsman}

Article 2(2) of the European Ombudsman Statute (hereinafter "the Statute") provides 
that "[a]ny citizen of the Union or any natural or legal person residing or having its registered office in a Member State of the Union may, directly or through a Member of the European Parliament, refer a complaint to the Ombudsman in respect of an instance of maladministration in the activities of Community institutions or bodies, with the exception of the Court of Justice and the Court of First Instance acting in their judicial role" (emphasis added). ${ }^{1}$ This provision corresponds to Article 195(1) EC. ${ }^{2}$ As to the definition of the phrase "maladministration", the Ombudsman says that "[m]aladministration occurs when a public body fails to act in accordance with a rule or principle which is binding upon it" (emphasis added). ${ }^{3}$ Under these provisions, the Ombudsman is entitled to address complaints to uncover failures to act lawfully.

In relation to the powers of the Community Court, Article 230(1) EC states that "[t]he Court of Justice shall review the legality of acts adopted jointly by the European Parliament and the Council, of acts of the Council, of the Commission and of the ECB, other than recommendations and opinions, and of acts of the European Parliament intended to produce legal effects vis-à-vis third parties" (emphasis added). In the EU FOI field, refusals of access to information include the decisions adopted by the Council or Commission, of which both the Ombudsman and the Court are entitled to examine the legality.

\footnotetext{
${ }^{1}$ The title "the European Ombudsman Statute" is commonly used at the website of the Ombudsman and in numerous decisions and reports made by this institution, but, strictly speaking, this is not the formal name of this legal instrument. Its official title is 94/262/ECSC, EC, Euratom: Decision of the European Parliament of 9 March 1994 on the regulations and general conditions governing the performance of the Ombudsman's duties [1994] OJ L113/15.

${ }^{2}$ As regards the Ombudsman, Article 195(1) EC provides that:

The European Parliament shall appoint an Ombudsman empowered to receive complaints from any citizen of the Union or any natural or legal person residing or having its registered office in a Member State concerning instances of maladministration in the activities of the Community institutions or bodies, with the exception of the Court of Justice and the Court of First Instance acting in their judicial role. (emphasis added)

3 The Ombudsman, The European Ombudsman Annual Report for 1997 (Strasbourg, European Ombudsman, 1998), 23.
} 
Two dividing lines can be drawn between the mandate of the Ombudsman and the jurisdiction of the Court. The first is set out in Articles 1(3) and 2(7) of the Statute. The former provides that " $[\mathrm{t}] \mathrm{he}$ Ombudsman may not intervene in cases before courts or question the soundness of a court's ruling". A more specific distinction is contained in the latter provision, which states that " $[\mathrm{w}] \mathrm{h}$. Ombudsman, because of legal proceedings in progress or concluded concerning the facts which have been put forward, has to declare a complaint inadmissible or terminate consideration of it, the outcome of any enquiries he has carried out up to that point shall be filed without further action". These articles indicate that the Ombudsman is entitled to examine the legality of particular acts only when the Court has not intervened. The second distinction is that the Court is competent to declare Community acts void while the role of the Ombudsman is to uncover maladministration, to criticise, and to make recommendations. The ways in which the Ombudsman carries out these duties will be considered further at $\mathbf{7 . 2}$ below.

In the FOI area, failure of the Council, the Commission, or the Parliament to act according to the 2001 Regulation and the relevant legal principles established in the case law constitutes an instance of maladministration. The Ombudsman is then entitled to review the legality of such a refusal. In the following subsection we will consider in more detail one of the issues raised above, i.e. how the various institutions would address the controversy that could arise where an applicant wishes to seek assistance from both the Ombudsman and the Community court.

\subsubsection{Complaints and Court proceedings}

Under Article 8(3) of the 2001 Regulation, failure by an institution to reply to 
confirmatory applications within the prescribed time limit "shall be considered as a negative reply and entitle the applicant to institute court proceedings against the institution and/or make a complaint to the Ombudsman, under the relevant provisions of the EC Treaty" (emphasis added). According to this provision, an applicant whose initial and confirmatory applications are refused is entitled to institute court proceedings against the institution concerned, or, alternatively, to make a complaint to the Ombudsman. It also would appear to suggest that an individual might pursue both options. Little controversy could arise if the applicant exercises only one of the two rights set out in Article 8(3) of the Regulation. Nevertheless, this provision could prove confusing where the applicant decides to exercise both rights.

Is the applicant entitled to complain to the Ombudsman and to bring the same case to the Court as well? The answer to this question differs when we take into account the following situations. First, where the applicant complains to the Ombudsman without initiating court proceedings, the applicant remains entitled to bring the same facts to the Court after being informed of the result of the complaint. Nevertheless, in the next two situations, the complaints will be declared inadmissible, or consideration of them will be terminated, by the Ombudsman, according to Article 2(7) of the Statute, noted above.

(1) The applicant complains to the Ombudsman and then initiates court proceedings without having been informed of the result of the complaint.

(2) The applicant initiates court proceedings and then complains to the Ombudsman. 
This analysis indicates that if the applicant wishes to exercise both rights laid down in Article 8(3) of the Regulation, two conditions must be met if Article 2(7) of the Statute is to be complied with:

(1) The applicant must complain to the Ombudsman before initiating court proceedings.

(2) The court proceedings should never be initiated prior to the receipt of the outcome of the complaint.

Otherwise, only the right to initiate court proceedings can be properly exercised. In other words, the expression in question in Article 8(3) of the Regulation, i.e. "to institute court proceedings against the institution and/or make a complaint to the Ombudsman", could be extremely misleading for those whose initial and confirmatory requests are refused by the Council, the Commission, or the Parliament. It would not be surprising at all if some assume that they are entitled to take advantage of the two rights concurrently. To eliminate the vagueness in Article 8(3) of the Regulation, this provision should be revised to include clear procedural guidance.

\subsection{Procedures open to the Ombudsman in the course of an inquiry}

This section analyses how the Ombudsman exercises his or her powers to realise FOI 
protection within the Union. According to Article 3(1) of the Statute, "[t]he Ombudsman shall, on his own initiative or following a complaint, conduct all the enquiries which he considers justified to clarify any suspected maladministration in the activities of Community institutions and bodies". The Ombudsman has not conducted an own-initiative FOI-related enquiry since the 2001 Regulation came into force. ${ }^{4}$ We will, therefore, focus on the procedures relating to the handling of complaints. Particular attention will be given to how complaints can be closed.

In 2002, 248 inquires were closed with reasoned decisions, 51.6 percent of which were closed as no maladministration was found. ${ }^{5}$ In 2003,180 inquires were .closed with reasoned decisions, 47.3 percent of which were closed as no maladministration was found. ${ }^{6}$ Other relevant breakdowns will be referred to in the

\footnotetext{
${ }^{4}$ The Ombudsman made three FOI-related draft recommendations on his own-initiative inquiries before the 2001 Regulation came into force:

A. Draft recommendation of the European Ombudsman on the own inquiry into public access to documents (616/PUBAC/F/IJH), http://www.euro-ombudsman.eu.int/recommen/en/317764.htm. The Ombudsman made this draft recommendation following an own-initiative inquiry into public access to documents held by the Community institutions and bodies, other than the Council and Commission. This inquiry ended up in a special report to the Parliament, in which the Ombudsman stated that the institutions and bodies had adopted certain rules that represented "a significant step forward in improving the transparency of Community administration, in accordance with the expectations, and to the benefit, of European citizens".
}

B. Draft recommendation to the European Commission in the own initiative inquiry 1004/97/PD, http://www.euro-ombudsman.eu.int/recommen/en/971004.htm. In this draft recommendation, the Ombudsman said that "[t]he Commission shall make known to applicants in oral exams the names of the Members of the Selection Board. In its future competitions, the Commission shall give applicants access to their own marked exam papers upon request".

C. Draft recommendations to Europol in own initiative inquiry OI/1/99/IJH into public access to documents, http://www.euro-ombudsman.eu.int/recommen/en/oi990001.htm. The Ombudsman made the following draft recommendations to Europol:

1. Europol should adopt rules concerning public access to documents within three months. The rules could be based on those already adopted by the Council, including the exceptions contained therein.

2. The rules should apply to all documents that are not already covered by existing legal provisions allowing access or requiring confidentiality.

3. The rules should be made easily available to the public.

5 The Ombudsman, The European Ombudsman, Annual Report 2002 (Luxembourg, Publications Office, 2003), 264.

6 The Ombudsman, The European Ombudsman, Annual Report 2003 (Luxembourg, Publications Office, 2004), 269. 
following subsections.

\subsubsection{Complaints settled by the institution involved}

The Ombudsman, according to Article 3(1) of the Statute, shall inform the institution or body concerned of such inquiry, which may submit any useful comment to the Ombudsman. What the relevant public body can do after being informed of an inquiry is in fact much more than submitting a comment. The institution or body concerned may take effective steps "to settle the case to the satisfaction of the complainant. If the opinion and observations show this to be so, the case is then closed as 'settled by the institution",? In practice, this is a common ground for closing an inquiry. It is, however, not mentioned in the Statute or Decision of the European Ombudsman adopting implementing provisions (hereinafter "the Implementing Decision"), ${ }^{8}$ though it will clearly be unnecessary to continue an inquiry when a complainant is absolutely satisfied with the efforts made by the relevant public body.

As to a complaint about refusal of access to information, a settlement could take place when the Council, the Commission, or the Parliament provides the complainant with all or part of the requested information. A complaint could also be settled where the complainant is fully satisfied with the explanations given by the relevant institution or body of the reasons why access must not be granted.

\footnotetext{
${ }^{7}$ The Ombudsman, n. 6 above, at 32; European Ombudsman, What can the Europcan Ombudsman Do for You? The European Ombudsman, A Guide for Citizens (Luxembourg, Publications Office, 2002), 8.

${ }^{8}$ Decision of the European Ombudsman adopting implementing provisions of 8 July 2002 and amended by decision of the Ombudsman of 5 April 2004, http://www.euro-ombudsman.eu.int/lbasis/en/provis.htm\#def1
} 
In $2002,25.8$ percent of the 248 inquiries closed with reasoned decisions were closed as the complaints were settled by the institution involved. ${ }^{9}$ In $2003,26.1$ percent of the 180 inquiries closed with reasoned decisions were closed as the complaints were settled by the institution involved. ${ }^{10}$ It was, however, unclear how many of the complaints settled by the institution involved concerned FOI protection.

\subsubsection{Friendly solutions}

According to Article 3(5) of the Statute, "[a]s far as possible, the Ombudsman shall seek a solution with the institution or body concerned to eliminate the instance of maladministration and satisfy the complaint". This is the duty to seek a friendly solution, a term employed in the Implementing Decision and widely used in the annual reports published by the Ombudsman. This obligation marks a major difference between the role of the Ombudsman and that of the Community court. The latter does not bear the legal duty to serve as a mediator to seek an amicable end to a judicial dispute. For complainants, there might be little difference between complaints closed by friendly solutions and those settled by the relevant public bodies, discussed above. This is because the complainants are fully satisfied in both situations. Similarly, when a friendly solution is secured for a complaint about a refusal of access to information, the complainant could be offered all or part of the requested information, or a satisfactory explanation of the refusal.

Nevertheless, two major differences between a friendly solution and a

\footnotetext{
9 The Ombudsman, n. 5 above.

10 The Ombudsman, n. 6 above.
} 
settlement must be noted. First, in the situation where a friendly solution is sought for a complaint, that complainant is completely satisfied owing to the mediation of the Ombudsman, but when a complaint is settled by the public body concerned, it is that public body that plays the key role. Second, in the former case, the Ombudsman has not yet formally found any failure to act lawfully, while in the latter situation, the Ombudsman has discovered that there is an instance of maladministration.

In 2002, six inquires were closed as friendly solutions were sought, while in 2003, friendly solutions were sought for four inquiries, according to the 2002 and 2003 Ombudsman reports. ${ }^{11}$ However, these reports do not indicate how many of the 10 inquiries concerned FOI protection.

\subsubsection{Critical remarks by the Ombudsman}

Under Article 3(6) of the Statute, "[i]f the Ombudsman finds there has been maladministration, he shall inform the institution or body concerned, where appropriate making draft recommendations". This indicates that if there has been maladministration, and a friendly solution has not been obtained, the Ombudsman can make a draft recommendation where appropriate. In practice, however, it is more common for the Ombudsman to close the inquiry with a critical remark to the relevant public body than to make a draft recommendation. The former course of action is specified in the Implementing Decision but not in the Statute. Under what circumstances will the Ombudsman make a critical remark, rather than a draft recommendation to the public body concerned? Under Article 7.1 of the

\footnotetext{
$"$ The Ombudsman, n. 5 and 6 above.
} 
Implementing Decision, the Ombudsman can make a critical remark if he or she considers:

(a) that it is no longer possible for the institution concerned to eliminate the instance of maladministration and;

(b) that the instance of maladministration has no general implications.

The second condition is particularly important because it indicates that, generally, a draft recommendation is much more influential than a critical remark and is more likely to be referred to in future complaints.

In 2002,29 of the 180 inquiries closed with reasoned decisions were closed with a critical remark addressed to the institution involved. ${ }^{12}$ In 2003,20 of the 180 inquiries closed with reasoned decisions were closed with a critical remark addressed to the institution involved. ${ }^{13}$

\subsubsection{Draft recommendations and special reports}

Under Article 8.1 of the Implementing Decision, the Ombudsman makes a report containing draft recommendations to the institution concerned if he or she considers either:

(a) that it is possible for the institution concerned to eliminate the instance of maladministration, or

\footnotetext{
12 The Ombudsman, n. 5 above.

13 The Ombudsman, n. 6 above.
} 
(b) that the instance of maladministration has general implications.

"The institution or body so informed shall send the Ombudsman a detailed opinion within three months", according to Article 3(6) of the Statute. After the Ombudsman receives a detailed opinion sent by the public body concerned, he or she "shall then send a report to the European Parliament and to the institution or body concerned" and may make recommendations in the report, according to Article 3(7). The phrase "shall" in this provision indicates that the duty to make a special report is mandatory. This obligation is, however, discretionary under Article 8.4 of the Implementing Decision. This provision provides that "[i]f the Ombudsman does not consider that the detailed opinion is satisfactory he may draw up a special report to the European Parliament in relation to the instance of maladministration". It is then necessary to consider what would be regarded as an acceptable response to a draft recommendation. What must be included in a satisfactory opinion? According to Article 8.3 of the Implementing Decision, "[t]he detailed opinion could consist of acceptance of the Ombudsman's decision and a description of the measures taken to implement the draft recommendations". In other words, full acceptance and implementing measures are considered indispensable elements of an acceptable reply.

In 2002, 10 inquiries were closed with draft recommendations accepted by the institutions concerned, while three others ended up in special reports to the Parliament. ${ }^{14}$ In 2003, five inquiries were closed with draft recommendations accepted by the institutions concerned, and two others ended up in special reports to

\footnotetext{
14 The Ombudsman, n. 5 above.
} 
the Parliament. ${ }^{15}$ The Ombudsman made nine draft recommendations concerning FOI-related complaints between 2002 and 2004, including two that ended up in special reports to the Parliament. All these draft recommendations and special reports will be examined at 7.3 below.

\subsubsection{Summary of possible outcomes}

The following are the key potential outcomes of complaint-initiated inquiries:

(1) When a complaint is settled, the complainant is fully satisfied with the steps taken by the relevant institution or body.

(2) Where a friendly solution is sought, both the complainant and the public body concerned are satisfied owing to the mediation of the Ombudsman.

(3) Where an inquiry reveals no maladministration, the complainant will be informed of the reasons why the Ombudsman believes that the relevant institution or body has not failed to act lawfully.

(4) The Ombudsman may make a critical remark when an inquiry reveals an instance of maladministration that has no general implications and no follow-up action is necessary.

(5) Draft recommendations are made in cases involving serious maladministration or those that have general implications. The Ombudsman makes a special report to the Parliament if the public body concerned does not accept the draft recommendation.

\footnotetext{
${ }^{15}$ The Ombudsman, n. 6 above.
} 
We will now focus on the role of draft recommendations made by the Ombudsman, in particular those that ended up in special reports to the Parliament. Under the present legal framework, these recommendations are intended to eliminate the most serious FOI-related maladministration with general implications.

\subsection{Draft recommendations and special reports}

The main objectives of our examination of draft recommendations and special reports are:

(1) to analyse the legal debates surrounding the most contentious exceptions to openness that have been addressed by the Ombudsman;

(2) to identify whether there is room for the Ombudsman to improve the way he or she guarantees freedom of information;

As to the second purpose, a watchful eye must be kept on whether the Ombudsman has followed the procedures set out in the Statute and the Implementing Decision when it contributes to FOI protection. A failure to meet any of these procedural requirements also constitutes an instance of maladministration.

The Ombudsman made nine draft recommendations between 2002 and 2004 in relation to complaints concerning refusals of access to information, two of which ended up in special reports to the Parliament. It bears noting that the Ombudsman made only three special reports to the Parliament during the three year period, while 
two of them concerned FOI protection. ${ }^{16}$ Special attention will be drawn to one of the two special reports that concerned a complaint against the Parliament. How much sense, if at all, does it make for the Ombudsman to make a special report to the Parliament after the Parliament has itself declined to give a satisfactory reply to a draft recommendation?

As to the refusals involved in the nine complaints, two of the complaints involved Council refusals of access to legal opinions of the institution, which primarily concerned the exception relating to legal advice in Article 4(2) of the 2001 Regulation. This provision provides that "[t]he institutions shall refuse access to a document where disclosure would undermine the protection of ... court proceedings and legal advice, $\ldots$ unless there is an overriding public interest in disclosure".

Six other complaints, which involved the Council and Commission, related to the refusals of access to their information concerning internal proceedings. These cases mainly concerned the exception relating to protection of institutional proceedings set out in Article 4(3) of the Regulation, which states that:

Access to a document, drawn up by an institution for internal use or received by an institution, which relates to a matter where the decision has not been taken by the institution, shall be refused if disclosure of the document would seriously undermine the institution's decision-making process, unless there is an overriding public interest in disclosure. Access to a document containing opinions for internal use as part of deliberations and preliminary consultations within the institution concerned shall be refused even after the decision has been taken if disclosure of the document would seriously undermine the

\footnotetext{
${ }^{16}$ In the other special report, the Ombudsman recommended that Commission should reconsider its rules concerning the classification of posts of press officers in its delegations in third countries in general and in particular the classification of the post of the complainant, Mr. Shahzad Badar. He was the Press and Information officer at the Commission's Delegation in Islamabad. The Ombudsman, Special Report from the European Ombudsman to the European Parliament following the draft recommendation to the European Commission in own-initiative inquiry OI/2/2003/GG, 1, 9, and 10, http://www.euro-ombudsman.eu.int/special/pdf/en/oi030002.pdf
} 
institution's decision-making process, unless there is an overriding public interest in disclosure. (emphasis added)

The remaining complaint concerned a refusal by the Parliament based on rights and citizenship set out in the Member States Constitutions and the Charter of Human Rights. However, the Parliament did not refer to any specific provisions in the refusal. All these complaints are considered at the following subsections.

\subsubsection{Legal advice}

\subsubsection{Complaint 1542/2000/(PB)SM}

According to one of the two special reports, the complainant, who was a student, requested access, inter alia, to two opinions from the Legal Service of the Council, but this application was refused by the Council. ${ }^{17}$ The first document sought, $8443 / 00$, contained an analysis by the Legal Service as to how the Council should act in future cases analogous to T-188/98, ${ }^{18}$ while the other document sought, $7594 / 00$, was about the proposal for a regulation on freedom of information, namely the 2001 Regulation. ${ }^{19}$ In the inquiry, the Council told the Ombudsman that "a disclosure would undermine the protection of the public interest under Article 4(1) of Decision 93/731/EC and the Council's ability to obtain independent legal advice from its Legal Service". ${ }^{20}$ The Ombudsman drew a dividing line between different kinds of

\footnotetext{
${ }^{17}$ The Ombudsman, Special Report from the European Ombudsman to the European Parliament following the draft recommendation to the Council of the European Union in complaint 1542/2000/(PB)SM, 2, http://www.euro-ombudsman.eu.int/special/en/default.htm

${ }_{18}^{18}$ Case T-188/98, Kuijer v. Council [2000] 2 CMLR 400. This case concerned asylum seekers.

19 The Ombudsman, n. 17 above.

${ }^{20}$ The Ombudsman, n. 17 above, at 3. Under Article 4(1), access to a Council document shall not be granted where its disclosure could undermine the protection of the public interest (public security,
} 
legal opinions. ${ }^{21}$ As regards the first opinion, the Ombudsman said that the document was about possible future court proceedings and was "analogous to a written communication between a lawyer and a client", so "the Council was entitled in the present case to consider that its disclosure would, as a matter of principle, be contrary to the public interest". ${ }^{22}$ As to the other legal opinion in question, the Ombudsman said this document concerned the preparatory legislative process of the proposal concerned. ${ }^{23} \mathrm{He}$ stated that under Article 207(3) EC, "greater access to Council documents could be allowed in cases where the Council is to be regarded as acting in its legislative capacity". ${ }^{24}$ The Ombudsman concluded that the Council failed to give adequate reasons for refusing access to the second legal opinion, demanding that the Council reconsider the complainant's application, "unless one or more of the exceptions contained in Article 4 of Decision 93/731 applies". ${ }^{25}$

It should be noted that the detailed opinion of the Council and Ombudsman's evaluation of this opinion were based on the 2001 Regulation rather than Decision 93/731, as the new legislation came into force after the draft recommendation above was made. In its detailed opinion, the Council said it disagreed with the Ombudsman mainly on the ground that "Article 207(3) EC also provides that the Council is to strike a balance between greater access to documents relating to its legislative activities and the interest of preserving the effectiveness of its decision-making process in general". ${ }^{26}$ In response, the Ombudsman reiterated its view concerning

\footnotetext{
international relations, monetary stability, court proceedings, inspections and investigations).

${ }^{21}$ The Ombudsman, n. 17 above, at 1.

${ }^{22}$ The Ombudsman, n. 17 above, at 6.

23 The Ombudsman, n. 17 above, at 6.

${ }^{24}$ The Ombudsman, n. 17 above, at 6. Under Article 207(3) EC, for the purpose of Article 255(3) EC concerning FOI legislation, "the Council shall define the cases in which it is to be regarded as acting in its legislative capacity, with a view to allowing greater access to documents in those cases, while at the same time preserving the effectiveness of its decision-making process" (emphasis added).

${ }^{25}$ The Ombudsman, n. 17 above, at 6.

${ }^{26}$ The Ombudsman, n. 17 above, at 7.
} 
the distinction, noted above, stressing that "only the first type of legal opinions should be considered as 'legal advice' within the meaning of Article 4(2), second indent of Regulation 1049/2001". ${ }^{27}$ At the end of the special report, the Ombudsman said that "the Council's detailed opinion fails to provide sufficiently adequate reasons for its refusal to grant access to document 7594/00". He therefore recommends that the Council "reconsider the complainant's application and give access to the document requested, unless one or more of the exceptions other than Article 4(2), second indent of Regulation 2049/2001 applies". ${ }^{28}$

\subsubsection{Complaint 2371/2003/GG}

The draft recommendation made in April 2004 concerned a complainant, a research assistant of the University of Munich, who had requested access to an opinion of the Council's Legal Service for preparation of his thesis on EU asylum law, but his confirmatory application was refused by the Council on the basis of Article 4(2) of the 2001 Regulation. ${ }^{29}$ In the inquiry conducted by the Ombudsman, the Council took the view that "opinions of its Legal Service could, if they were disclosed, be used by others to mount legal challenges to the acts of the Council". The Ombudsman reiterated his views on the distinction between different types of legal opinions, noted above, and said that not all the Council arguments concerned possible future court proceedings. He went on to say that "[a]s the complainant correctly observed, Regulation 1049/2001 has the aim of ensuring the 'widest

\footnotetext{
${ }^{27}$ The Ombudsman, n. 17 above, at 11.

${ }^{28}$ The Ombudsman, n. 17 above, at 13.

${ }^{29}$ Draft recommendation to the Council of the European Union in complaint 2371/2003/GG, 1, http://www.euro-ombudsman.eu.int/recommen/en/032371.htm. The document at issue was Council document no 10678/99, an opinion of the Council's Legal Service concerning the application of the Protocol, annexed to the Treaty of Amsterdam, on asylum for nationals of Member States of the European Union.
} 
possible access to documents'. Article 4(2), second indent of Regulation No $1049 / 2001$ is thus an exception that needs to be interpreted narrowly, taking into account the principle of proportionality". The Ombudsman concluded that the Council failed to provide a satisfactory explanation for the refusal, recommending that the Council review its refusal.

\subsubsection{Comment}

As regards the two complaints above, the Council held the view that, on the one hand, disclosure of legal opinions would undermine its ability to obtain independent legal advice from its Legal Service, and, on the other hand, disclosed legal opinions could be used by others to mount legal challenges to the acts of the Council. As the Council did not mention any legal opinions that were likely to be made available to the public, it is obvious the institution was of the opinion that no legal opinion of its Legal Service should be released. In other words, the Council took the view that systematic refusal of access to legal opinions was compatible with Article 4(2) of the Regulation. This is, however, an incorrect opinion since under this provision, the Council bears the duty to consider whether "there is an overriding public interest in disclosure". As various public interests could be involved in different requests for access to this kind of information, such decisions must be made on a case-by-case basis.

However, the Ombudsman did not lay stress on the incompatibility of a systematic refusal with the balancing test required by Article 4(2) of the Regulation, but instead founded on the distinction between legal opinions concerning possible future court proceedings and those relating to the legislative process. This distinction could prove very problematic because, first of all, the rationale behind this dividing line is extremely fragile. In reliance on Article 207(3) EC, the Ombudsman argued 
that the public was entitled to have greater access to the Council's legal opinions concerning the legislative process. Nonetheless, relying on the same provision, the Council said Article 207(3) EC also provided that the effectiveness of its decision-making process must be preserved. In his response to the detailed opinion, the Ombudsman avoided elaborating on why this effectiveness would not be jeopardised were legislative-process-related legal opinions to be disclosed.

Secondly, this dividing line is incompatible with Article 4(2) of the Regulation, under which decisions should be made on a case-by-case basis. This provision neither indicates that a legal opinion must not be made available to the public if it relates to potential judicial disputes, nor does it entail that a legal opinion must be made available to the public where it concerns legislative process. In addition, the CFI held in the 2004 Turco judgment the phrase "legal advice" in Article 4(2) of the Regulation must be understood as meaning that the protection of the public interest might preclude the disclosure of the documents drawn up by the Council's legal service in the context of court proceedings, legislative activities, or for any other purpose. $^{30}$

Thirdly, a legal opinion concerning possible future cases is analogous to a written communication between a lawyer and a client, but they are not exactly the same. On the one hand, a practicing lawyer outside the Council is not under public scrutiny, but legal experts of the Legal Service must be put under the sharp public eye as they are public servants of the Union. On the other hand, a lawyer outside the institution may decline to advise a client if his or her legal advice is likely to be, or has been, disclosed to a third party, but the legal experts of the Legal Service are not entitled to do so. The Ombudsman, therefore, should not have held that this limited

\footnotetext{
${ }^{30}$ paras. 62 and 66. Case T-84/03, Maurizio Turco v. Council [2004] ECR II-0000.
} 
analogy entitled the Council to consider that its disclosure would be contrary to the public interest. The exception relating to legal opinion is intended to make certain that the legal professionals are able to offer legal advice without being fearful of undue influence. What the Ombudsman should have done was to determine whether there was an overriding public interest that was more important than the protection of the legal advice, but he failed to do so.

Fourthly, the distinction drawn by the Ombudsman might not be apparent where the Ombudsman is faced with a refusal of access to a document containing both kinds of legal opinion. When an expert of the Legal Service is required to comment on a proposed Community act, it is very likely that he or she would concurrently consider how to prevent possible future legal challenges to the act.

It can be concluded that the distinction founded by the Ombudsman is flawed in certain respects. A better strategy for the Ombudsman in countering Council systematic refusals of access to legal opinions would be to take the requirements in Article 4(2) into serious account, applying the balancing test on a case-by-case basis when addressing the relevant complaints.

\subsubsection{Confidentiality of institutional proceedings}

\subsubsection{Complaints regarding the Council: Complaint 573/2001/IJH}

In a draft recommendation made in June 2002, a complainant requested access to the second annual progress report from the Code of Conduct Group (Business Taxation) to ECOFIN -- the Council meeting in the formation of Economic and Finance 
Ministers. ${ }^{31}$ To protect its internal proceedings, the Council invoked Article 4(2) of Decision $93 / 731$ in its refusal of the complainant's confirmatory application. ${ }^{32}$ It argued in the inquiry that "[p]remature disclosure of the document could impede the ongoing deliberations and thereby run contrary to the general interest in achieving progress in the area of business taxation" (emphasis added). As the 2001 Regulation came into force after the complaint was made, the Ombudsman and Council agreed that re-examination of the request must be based on the Regulation. The Ombudsman considered that the refusal of the Council was "tainted by maladministration" since:

- the Council's reasoning is inadequate to explain its interest in the confidentiality of its proceedings as regards the document in question, or to demonstrate that disclosure of the document would seriously undermine the Council's decision-making process and

- the Council failed to address the question of partial access.

He states that the Council should reconsider the complainant's application and give access to the sought documents, unless one or more of the exceptions in Article 4 of the Regulation applied. The Council later accepted this recommendation.

\subsubsection{Complaints regarding the Commission}

\section{A. Complaint $1128 / 2001 / / J H$}

According to a draft recommendation which was also made in June 2002, a complainant, a representative of a Netherlands-based non-governmental organisation, requested the briefing notes of Commission delegations to two meetings of the

${ }^{31}$ Draft recommendation to the Council of the European Union in complaint 573/2001/IJH, http://www.euro-ombudsman.eu.int/recommen/en/010573.htm. This draft recommendation has been anonymised because this complaint was treated as confidential at the request of the complainant.

${ }^{32}$ Article 4(2) of Decision 93/731 stated that "[a]ccess to a Council document may be refused in order to protect the confidentiality of the Council's proceedings". 
Transatlantic Business Dialogue (TABD) held in $1999 .{ }^{33}$ In its refusal, the Commission invoked the exception relating to protection of Commission proceedings set out in Decision $94 / 90 .^{34}$ It said that:

Depending on the general context of the discussions and appropriate political discretion, the position taken by the Commissioner may not always entirely correspond to the advice and proposed speaking points. Therefore giving access to these documents would be inappropriate and misleading to the public. Moreover, disclosure would compromise or complicate relations with the US.

Nevertheless, the Ombudsman found that in applying the discretionary exception, "the Commission has failed to show that it has struck a genuine balance between the interest of the citizen in obtaining access to the documents and its own well-founded interest in confidentiality. This is an instance of maladministration". He therefore stated that "[t]he Commission should reconsider the complainant's application and give access to the documents requested, unless one or more of the exceptions contained in Article 4 of Regulation 1049/2001 applies. The reconsideration should include the possibility of partial access, in accordance with Article 4(6) of Regulation 1049/2001". The Commission then accepted this recommendation.

\section{B. Complaint $1874 / 2003 / G G$}

The draft recommendation made by the Ombudsman in July 2004 concerned a complainant, a German non-governmental organisation, which had contracted with IBF, a Brussels-based body acting on behalf of the Commission, to execute a

\footnotetext{
33 Draft recommendation to the European Commission in complaint 1128/2001/JJH, http://www.euro-ombudsman.eu.int/recommen/en/011128.htm

${ }^{34}$ This provision is in fact the fourth section, second subsection of the Code of Conduct, which provided that the Council and Commission "may also refuse access in order to protect the institution's interest in the confidentiality of its proceedings".
} 
humanitarian project in Kazakhstan. ${ }^{35}$ The Commission was a co-financer of the project, supervision of which was entrusted to the Centre Européen du Volontariat (CEV) in Brussels. The Commission later cancelled this project. The complainant requested access to a file containing "internal documents, including those between the Commission and the external offices IBF and CEV". The letter in which the Commission replied to the request referred to the fact that the information at issue would not be disclosed, without giving any reasons. In the inquiry conducted by the Ombudsman, the Commission said that "the disclosure of these documents which contained opinions for internal use as part of deliberations and preliminary consultations would seriously undermine the decision-making process of the Commission". The Ombudsman stated that the reasoning given by the Commission in the letter replying to the complainant, namely no reason at all, was "manifestly inadequate to allow the complainant (and the Ombudsman himself) to understand why no access could be granted to these documents". Thus, the Ombudsman concluded that the Commission had failed to handle the complainant's request properly, which constituted an instance of maladministration. He therefore stated that the Commission should reconsider the complainant's request to grant full access to the documents at issue unless it could show that they were covered by any exceptions set out in the 2001 Regulation.

\section{Complaint $2028 / 2003 /(M F) P B$}

According to a draft recommendation made in October 2004, a complainant, who failed a written examination organised by the European Personnel Selection Office

\footnotetext{
35 Draft recommendation to the European Commission in complaint 1874/2003/GG., http://www.euro-ombudsman.eu.int/recommen/en/031874.htm
} 
(hereinafter "EPSO"), asked the EPSO to send her, inter alia, the selection criteria established and applied by the selection board, but the EPSO refused to do so. ${ }^{36}$ In the inquiry, the Commission referred to the Innamorati case of $1996 .^{37}$ In its view, the Commission said the ECJ held that "such criteria constitute an integral part of the deliberations of the selection board, and as such are covered by secrecy". The Commission said that access had to be refused under Article 4(3) of the Regulation, "as their release would seriously undermine the decision-making process of the board". The Ombudsman, however, disagreed, stating that Innamorati did not concern the issue of access to documents. "EPSO and the Commission therefore failed to give adequate reasons for refusing access. This constitutes an instance of maladministration". He stated that "EPSO should reconsider its refusal to provide the complainant access to the selection criteria established by selection board, and give access", unless valid grounds prevent their disclosure under any exceptions in the Regulation. The EPSO has not yet accepted this draft recommendation.

\section{Complaint 2097/2003/(ADB)PB}

The Ombudsman made a further draft recommendation two weeks later, addressing another complaint concerning a competition organised by the EPSO. ${ }^{38}$ The complainant who failed a German typing test asked the Commission for the selection criteria and a copy of her marked examination paper, but both requests were refused. In the inquiry, the Commission said those documents formed an integral part of the oral examination and that they were therefore covered by the secrecy referred to in

\footnotetext{
36 Draft recommendation to the European Personnel Selection Office in complaint 2028/2003/(MF)PB, http://www.euro-ombudsman.eu.int/recommen/en/032028.htm

${ }^{37}$ Case C-254/95P, Parliament v. Angelo Innamorati [1996] ECR I-3423.

38 Draft recommendation to the European Personnel Selection Office in complaint 2097/2003/(ADB)PB, http://www.euro-ombudsman.eu.int/recommen/en/032097.htm
} 
Article 6 Annex III of the Staff Regulations. ${ }^{39}$ It added that "[t]he practical examination took place the same day as the oral examination, for which reason the deliberations were covered by the secrecy appertaining to the selection boards". Nonetheless, as to the examination paper, the Ombudsman stated that " $[t]$ he fact that the practical test and the oral examination were held on the same day does not show that they were inseparable". As regards the selection criteria, the Ombudsman stated that the findings in his draft recommendation in complaint 2028/2003/(MF)PB, noted in the last paragraph, were "equally relevant and applicable to the present case". He concluded that the Commission's refusal to grant access to the documents at issue constituted two instances of maladministration, and made the following draft recommendations to EPSO:

1. EPSO should provide the complainant with a copy of her written examination paper.

2. EPSO should furthermore reconsider its refusal to give the complainant access to the evaluation criteria, and give access unless valid grounds prevent their disclosure.

The EPSO has not yet decided whether it will accept this draft recommendation.

\section{E. Complaint 413/2004/(MF)PB}

In another draft recommendation made in October 2004, the Ombudsman once again referred to his findings in the draft recommendation in complaint 2028/2003, when he was faced with the circumstances where the EPSO declined to provide the complainant with the individual evaluation sheet for her performance in a French

\footnotetext{
39 This provision states that the "proceedings of the Selection Board" are to be secret.
} 
translation test. ${ }^{40}$ In the inquiry, the Commission stressed that to make separate evaluation sheets public "would create a risk of external pressure and interference in the selection board's deliberations. Access to the separate evaluation sheets therefore had to be refused on the basis of the exception contained in Article 4(3)(ii) of Regulation 1049/2001". The Ombudsman disagreed and stated that his findings in his draft recommendation in complaint 2028/2003 "are equally relevant and applicable to the present case". He concluded that the reasons for not giving the complainant access to a copy of the detailed evaluation sheet were inadequate, which constituted an instance of maladministration. He stated that "EPSO should reconsider its refusal to give the complainant access to a copy of the detailed evaluation sheet, and give access unless valid grounds prevent its disclosure". This draft recommendation has also not yet been accepted by the EPSO.

\subsubsection{Comment}

It must be stressed in the first place that under Article 4(3) of the 2001 Regulation, access shall be refused only if disclosure "would seriously undermine the institution's decision-making process". Recital 11 of the preamble to the Regulation provides that the Council, the Commission, and the Parliament "should be entitled to protect their internal consultations and deliberations where necessary to safeguard their ability to carry out their tasks" (emphasis added). On the basis of this statement, it is fair to say that such refusals can be made only in situations where disclosure is so detrimental that the operation of the institutional work would be jeopardised.

Nonetheless, the Council and Commission failed to take into account the

\footnotetext{
40 Draft recommendation to the European Personnel Selection Office in complaint 413/2004/(MF)PB, http://www.euro-ombudsman.eu.int/recommen/en/040413.htm
} 
requirement set out in Article 4(3) of the Regulation. The main features of the Council and Commission's invocation of Article 4(3) are that, first, in these refusals the institutions sought to guarantee various kinds of general interest not specified in the governing Regulation, or they failed to specify any interest at all. Secondly, the two institutions showed little respect for the balancing test required by this provision.

These conclusions are elaborated on in more detail in the points below:

(1) As far as the taxation report was concerned, the Council wished to secure the general interest in the area of business taxation, but the institution failed to explain how its internal proceedings could seriously be damaged by the disclosure of the information.

(2) As to the briefing notes prepared for the transatlantic meetings, the Commission said disclosure would be inappropriate and misleading to the public and would complicate relations with the US. First, the public could indeed get confused when noticing that the position of the Commissioner did not entirely correspond to the briefing notes concerned. However, it was not difficult for the Commission to eliminate such confusion as it could attach a cover letter to the briefing notes when making disclosure, noting that these documents should be understood as briefing notes only. Secondly, the Commission did not consider the extent to which disclosure would complicate the EU-US relations. This is an important issue because the exception relating to internal proceedings can be invoked only where the decision-making process of the Commission or the Council would be substantially undermined. The mere fact that the mutual relations could be complicated must not be regarded as serious jeopardy. 
(3) As regards the documents about the humanitarian project, the Commission did not even mention what was the interest that would be secured in the refusal.

(4) As to the first complaint regarding Community examinations, the Commission referred to an ECJ judgment, which did not concern freedom of information, in support of its invocation of Article 4(3). The Commission did not elaborate on why the proceedings of the selection board would be seriously undermined.

(5) The Commission responded to the second examination complaint by referring to a provision of the Staff Regulations, which provides that proceedings of a selection board should be covered by secrecy. This provision, which indicates that deliberations of a selection board must remain secret, does not entail that the selection criteria themselves should be kept secret.

(6) In the inquiry into the third examination complaint, the Commission argued that access to the evaluation sheet would create a risk of external pressure and interference in the deliberations of the selection board. It is, however, unthinkable that there could be any illegal intervention, or how the deliberations concerned could be seriously undermined when the Selection Board had made its final decision on the outcome of a specific competition.

In brief, the Council and Commission failed to consider whether any specific public interests would be significantly jeopardised so that their internal work could not proceed. The institutions also failed to take into account what were the interests of 
the applicants in accessing the information.

Generally, the Ombudsman has made considerable efforts to prevent the two institutions from holding that the general interests, which were not specified in the governing FOI laws, prevailed over freedom of information. Nevertheless, it was improper for the Ombudsman to hold the view that his findings in the draft recommendation in complaint 2028/2003/(MF)PB were "equally relevant and applicable" to the two other complaints.

First, the Ombudsman is certainly entitled to reiterate his opinions on specific issues, but what the complainants requested in the three cases were different kinds of information. The information in question in complaint 2028/2003 was selection criteria, but the document concerned in 413/2004 was the individual evaluation of the complainant's performance in a test. It is doubtful that the findings of the Ombudsman in the former case were equally applicable to the latter, and at least further elaboration was required. Second, as there were significant differences between the arguments put forward by the Commission in the inquiries into the three complaints, the findings of the Ombudsman in the first case were not necessarily relevant to the two others. In complaint 2028/2003, the Commission claimed that it was entitled to invoke Article 4(3) as the ECJ had held that selection criteria were covered by secrecy. However, in complaint 2097/2003, the Commission argued that such criteria were covered by secrecy under Article 6 Annex $\amalg$ of the Staff Regulations. And in complaint 413/2004, the Commission said its refusal was based on Article 4(3)(ii) of the Regulation as access could bring pressure and interference to the selection board deliberations. The Ombudsman, however, said in the two latter cases that its findings in the former equally applied in the latter cases. In fact, the Ombudsman failed to respond to the argument about Article 6 Annex $\amalg$ of the Staff 
Regulations and that concerning extra pressure in the two latter cases. It was, therefore, inappropriate for him to rule on an instance of maladministration without addressing the main arguments presented by the Commission.

\subsubsection{Protection of personal data}

\subsubsection{Complaint 341/2001/(BB)IJH}

According to another Ombudsman special report, a complainant, who failed in a competition for typists organised by the Parliament, asked the Parliament for the names and marks of the successful candidates but the request was refused. ${ }^{41}$ In the inquiry, the Parliament said unsuccessful candidates could not "be informed of the reserve list without violating the Constitutions of Member States and the rights of citizens under the Charter of Fundamental Rights of the European Union" (emphasis added). The Ombudsman said the Parliament appeared to have acted according to the previously-published notice of competition. ${ }^{42}$ Nonetheless, the Ombudsman considered it "to be inconsistent with Parliament's commitment to openness in the recruitment process for its administration to fail to announce, in notices of competition, that the names of successful candidates will be made public". ${ }^{43} \mathrm{He}$ found no maladministration in his inquiry but made the following draft

\footnotetext{
${ }^{41}$ The Ombudsman, Special Report from the European Ombudsman to the European Parliament following the draft recommendation to the European Parliament in complaint 311/2001/(BB)IJH, 2, http://www.euro-ombudsman.eu.int/special/en/default.htm

${ }^{42}$ The Ombudsman, n. 41 above, at 3.

${ }^{43}$ The Ombudsman, n. 41 above, at 4 . In support of this conclusion, the Ombudsman referred to a Parliament resolution in which the Parliament stressed that the principle of openness must apply throughout the Commission recruitment procedures. European Parliament resolution on the special report from the European Ombudsman to the European Parliament following the own-initiative inquiry into the secrecy which forms part of the Commission's recruitment procedures (C5-0082/2000 - 2000/2048 (COS)), 17 November 2000.
} 
recommendation "to guarantee that the principle of openness will be applied in future competitions": "In future competitions, the European Parliament should inform candidates in the notices of competition that the names of successful candidates will be made public". ${ }^{44}$

Nevertheless, the Parliament did not accept the draft recommendation on the ground that the publication of the name of a successful candidate could be deemed "to be lawful only if the person in question has unambiguously given his or her consent to such publication", according to Article 5(d) of Regulation 45/2001. ${ }^{45}$ The Parliament stressed that participating in a competition whose notice stated that the list of successful candidates would be published could not be regarded as the unambiguous consent. ${ }^{46}$ In response, the Ombudsman said the Parliament misunderstood the Community data protection law since the publication of the information concerned was permitted under Article 5 of Regulation 45/2001. ${ }^{47}$ The Ombudsman, therefore, made the following recommendation: "In future competitions, the European Parliament should publish the names of successful

\footnotetext{
${ }^{44}$ The Ombudsman, n. 41 above, at 4.

${ }^{45}$ The Ombudsman, n. 41 above, at 1 . Under this provision, personal data may be processed only if "the data subject has unambiguously given his or her consent". $\Lambda$ s to the definition of the phrases "data subject" and "the data subject's consent", Article 2(a) of Regulation 45/2001 provides that data subject refers to an identified or identifiable natural person, and Article 2(h) of Regulation 45/2001 states that "'the data subject's consent' shall mean any freely given specific and informed indication of his or her wishes by which the data subject signifies his or her agreement to personal data relating to him or her being processed". Regulation (EC) No 45/2001 of the European Parliament and of the Council of 18 December 2000 on the protection of individuals with regard to the processing of personal data by the Community institutions and bodies and on the free movement of such data [2001] OJ L8/1.

${ }^{46}$ The Ombudsman, n. 41 above, at 4.

47 The Ombudsman, n. 41 above, at 6. The Ombudsman referred to Article 5(a) of Regulation 45/2001 in support of his view. Under this provision, personal data may be processed if "processing is necessary for the performance of a task carried out in the public interest .... in the legitimate exercise of official authority vested in the Community institution or body". The Ombudsman stated that "it would be a legitimate exercise of official authority for the European Parliament to decide that the names of successful candidates in competitions will be published and that candidates will be informed accordingly in the notice of competition".
} 
candidates and inform candidates accordingly in the notices of competition". ${ }^{48}$ Finally, the Ombudsman stated that "[t]he European Parliament could consider adopting the recommendation as a resolution" ${ }^{49}$ The Parliament later accepted this recommendation.

\subsubsection{Comment}

This special report indicates that the Parliament did not address the request properly, and the Ombudsman's way of dealing with this complaint was far from perfect.

\section{A. A refusal without clear legal basis}

The Parliament said in the inquiry that disclosure of the information concerned would violate the Constitutions of Member States and the rights of citizens under the Charter of Fundamental Rights of the European Union (hereinafter the "Charter"). This argument was flawed because it lacks of specificity. In this statement, the Parliament failed to point out which parts of the Constitutions and the Charter would be violated. The most relevant provision in the Charter is Article II-68 entitled "Protection of personal data", which states that:

1. Everyone has the right to the protection of personal data concerning him or her.

2. Such data must be processed fairly for specified purposes and on the basis of the consent of the person concerned or some other legitimate basis laid down by law. Everyone has the right of access to data which has been collected concerning him or her, and the right to have it rectified.

3. Compliance with these rules shall be subject to control by an

\footnotetext{
48 The Ombudsman, n. 41 above, at 6.

49 The Ombudsman, n. 41 above, at 6.
} 
independent authority.

It bears noting that the Parliament did not refer to the Charter or Constitutions of the Member States again after the Ombudsman made the draft recommendation. In its detailed opinion, the Parliament turned to claim that the refusal was based on Article 5(d) of Regulation 45/2001. Privacy is indeed guaranteed under not only the Charter and the Constitutions, but also Regulation 45/2001. However, the point was that the Parliament did not state in the refusal or the inquiry that the access was refused on the basis of Article 4(5) of Regulation 45/2001, Article II-68 of the Charter, or any provisions in the Constitutions. If the Parliament had referred to either of these provisions in the refusal or the inquiry, the complainant could have decided not to complain to the Ombudsman, or to drop the complaint if he has brought this case to the Ombudsman. This failure to give adequate reasoning in the refusal ran against Article 253 EC, which constituted an instance of maladministration.

The Ombudsman did not focus on this failure but argued that the publication of the names and marks of the successful candidates was permitted under Article 5(a) nf Regulation 45/2001. Although he held this view, he did not find that the refusal to publish constituted an instance of maladministration. This is because he believed that the Parliament acted according to the previously-published notice of the competition.

\section{B. Abuse of mandate?}

The Ombudsman found that the Parliament acted according to the notice of the competition, but he insisted on making the draft recommendation and special report. The reason why the Ombudsman made the draft recommendation and the special report, which consisted of a recommendation, was that the refusal was inconsistent 
with a commitment to openness made by the Parliament at an earlier date. ${ }^{50}$

Under Article 195(1) EC and Article 2(2) of the Statute, the Ombudsman has sole competence to act to eliminate maladministration, which refers to failure of a public body to act according to a rule or principle which is binding upon it. ${ }^{51}$ Where he or she finds no maladministration in an inquiry, the case should be closed subsequently. Draft recommendations and special reports to the Parliament are made where there is an instance of maladministration. It must be stressed that where the Ombudsman makes these recommendations or reports without uncovering any maladministration, such acts are themselves instances of maladministration, which constitute an abuse of the mandate of the Ombudsman.

Given that the Ombudsman found no maladministration in the present case, the making of the draft recommendation and special report was an abuse of the Ombudsman's mandate, which itself constituted an instance of maladministration. Surprisingly, the Parliament's detailed opinion indicated that it did not even notice that the draft recommendation was not based on any maladministration. However, even if it had noticed this flaw, the Parliament was not entitled to challenge the views and recommendation made by the Ombudsman in the special report under Article 230 EC. This is because special reports, which do not have legal effects on the Parliament, are not among the reviewable acts set out in this article.

\footnotetext{
50 n. 43 above.

${ }^{51}$ For text of Article 195(1) EC, see n. 5 of the introduction to this chapter. See also 7.1.1 above.
} 


\subsection{Conclusion}

Our analysis of the mandate of the Ombudsman, the procedures under which he/she exercises his/her powers, and the most contentious complaints concerning freedom of information, indicates that the Ombudsman has made considerable efforts in securing this right in the Union. The Ombudsman has adopted a very strict approach when assessing the three institutions' invocation of the exceptions set out in the EU FOI laws. This contribution is of great importance because the attitudes of the three institutions towards public access give cause for concern. Our study demonstrates, first of all, that as regards the public interest exception relating to legal advice, the Council took the view that systematic refusal of access to legal opinions was compatible with Article 4(2) of the Regulation. Secondly, as to protection of confidentiality of institutional proceedings, the Council and Commission's invocation of Article 4(3) showed they considered that freedom of information was less important than certain general interests not specified in the governing FOI laws. Thirdly, many might be surprised that it was the Parliament that made one of the most contentious refusals considered by the Ombudsman after the 2001 Regulation came into force. Analysis of this refusal, which was addressed in the special report on complaint $341 / 2001$, demonstrates that the Parliament did not consider the refusal in a serious manner prior to the Ombudsman's draft recommendation.

We should applaud the Ombudsman for what he has contributed to FOI protection, but there remains considerable room for improvement. As to legal reasoning, a number of flaws can be found in the way the Ombudsman has dealt with the relevant complaints. The first flaw can be found in the draft recommendations 
relating to the legal advice exception. The Ombudsman stressed the importance of the principle of "widest possible access", the principle of proportionality, and Article 207(3) EC, while he even drew a distinction between legal opinions relating to possible future court proceedings and those relating to the legislative process. However, he did not make sufficient effort to establish why the refusals of the Council were incompatible with these legal rules and principles. Secondly, the Ombudsman needs to be more careful about the way in which he or she makes use of references to previous opinions. For instance, Complaints 2028/2003, 2097/2003, and 413/2004 all concerned Community examinations, but the information sought by these complainants differed, and the Commission put forward significantly different arguments in the inquiries into these complaints. It was thus unhelpful for the Ombudsman to say that its findings in the draft recommendation relating to the first complaint equally applied to the two others, without addressing the arguments presented by the Commission. Thirdly, the Ombudsman needs to be careful to evaluate the scope of his/her mandate. Otherwise, addressing a complaint could constitute an instance of maladministration. The most important example can be found in the special report on complaint $341 / 2001$, in which the Ombudsman made a draft recommendation and then a special report to the Parliament without finding an instance of maladministration.

Finally, the Ombudsman should be extremely careful as to how he/she expresses views on FOI complaints. This is because, first, in the inquiries conducted by the Ombudsman, the Council and Commission have repeatedly referred to previous views of the Ombudsman in defence of their refusals. Second, the Ombudsman is entitled only to recommend. The relevant institutions and bodies, in particular the Parliament, will accept a draft recommendation or recommendation mainly because 
the legal reasoning of the Ombudsman is thought to be convincing. The Ombudsman has no powers to take any effective action where its draft recommendations are ignored. It should also be noted that before the Community court, the Ombudsman does not possess the right to challenge the legality of the acts adopted jointly or individually by other institutions and bodies.

The role of the Ombudsman is likely to remain important in the FOI field in the future and the Ombudsman will continue to act as the guardian of freedom of information. However, we should also keep a watchful eye on whether the Ombudsman and the Community court relax their high standards, if a revised or future Treaty extends the scope of FOI protection to documents in their possession. 


\section{8 \\ Conclusion}

This thesis is in three parts. The first and second parts analyse the development of the law and policy on freedom of information in the European Economic Community and European Union between 1984 and 2004. These two parts focus on how the Council, the Commission, and the Parliament enacted and implemented the rules on FOI protection, and on the role of the Community court in this field. The third part examines the roles of the European Parliament and the European Ombudsman, which have supplemented the role of the Court in securing this right. As to the objectives of this project: on the one hand, it seeks to understand the degree of legal protection offered to freedom of information in the Union over the last two decades; on the other, it seeks to identify how the current EU FOI regime could be improved. To accomplish these objectives, attention has been drawn to the following interrelated issues:

(1) What were the major controversies surrounding FOI law and policy between 1984 and 2004? In particular, this thesis focuses on the extent to which the 2001 Regulation addresses the pre-existing obstacles to FOI protection.

(2) The exceptions in Article 4(1) and Article 4(2) of the 2001 Regulation can be categorised as mandatory and discretionary respectively, but the distinction between the two provisions is vague. This indistinct 
dividing line should be removed to end the misunderstanding that the Council, the Commission, and the Parliament are entitled to refuse requests systematically when invoking the so-called mandatory exceptions.

(3) What are the principles established by the 2001 Regulation, the EC Treaty, or by the Court to guide the interpretation of the exceptions laid down in the Regulation?

(4) Should the EU legislator expressly incorporate the principle of proportionality into the 2001 Regulation?

(5) What can we learn from recent initiatives to adopt a constitution for Europe, and in the light of the "no" votes to the Treaty establishing a Constitution for Europe in the referendums in France and the Netherlands in mid 2005, what further steps are now required to guarantee freedom of information in the future?

This chapter draws together these important issues and considers them systematically. The first section reviews the dramatic shifts in position of the Council and Commission towards FOI protection. It looks at the case law and annual reports which demonstrate the institutions' questionable interpretation of the exceptions relating to inspections, investigations, court proceedings, and of the authorship rule. Following this assessment, we highlight in the second section how such controversies might be reduced before focusing on the function played by the principle of proportionality. In the final part of this chapter, the impact of the troubled ratification of the Treaty establishing a Constitution for Europe on the 2001 Regulation will be examined. 


\subsection{What ground has been covered?}

This thesis has considered the relevant legal rules, case law, and policy documents regarding EU FOI protection. Between 1984 and 1992 no Community law on freedom of information required the Community institutions to make their information publicly available. The Parliament adopted two Resolutions calling on the Commission and the Council to, inter alia, adopt FOI legislation, but these appeals fell on deaf ears. ${ }^{1}$

It is worth noting that these two institutions ultimately did not benefit from ignoring the Parliament's calls. Examination of the 1990 Zwartveld judgment indicates that the Community clearly needed FOI legislation. ${ }^{2}$ As there was no such legislation in place, the Dutch official in that case requested the Commission to provide him with inspection reports in the name of judicial cooperation. The Commission refused the request on the ground that "the documents formed part of a file on legal matters pending in the Commission", but it was also unable to provide any legal basis for this refusal. ${ }^{3}$ The ECJ read the principle of sincere cooperation in a very broad sense and decided that the Commission had to produce to the Dutch official the requested documents. ${ }^{4}$ The Court simply disregarded the Commission's argument regarding the protection of its internal proceedings, which had not yet been identified as an exception to openness in any EC legislation. The analysis of the first stage of the FOI evolution indicates that, on the one hand, it was difficult for the

\footnotetext{
' Resolution on the compulsory publication of information by the European Community [1984] OJ C172/176; Resolution on the compulsory publication of information by the European Community, [1988] OJ C49/174.

${ }^{2}$ Case C-2/88 Imm, Zwartveld and others [1990] ECR I-3365.

3 para. $1(\mathrm{v})$, n. 2 above.

${ }^{4}$ paras. $17,19,21,22,25$, and 26, n. 2 above.
} 
public to gain access to information in the possession of the Community institutions. On the other hand, the institutions did not have a firm legal basis on which to refuse access, however justified in the public interest. Both the public and the EC institutions can, therefore, be considered victims of the absence of FOI legislation between 1984 and 1992.

The public enjoyed more freedom of information under the 1992 Code of Conduct and the two corresponding Council and Commission decisions than they did prior to their adoption. These instruments, however, proved insufficient to offer comprehensive FOI protection. The Council and Commission between 1993 and 2004 tended systematically to refuse applications, which indicated that they still held to the view that secrecy ought to be the rule and openness the exception. This view is reflected in the following cases:

(1) In its 1995 Carvel judgment, the CFI held that the Council had considered that it was obliged to refuse access under the confidentiality exception because, inter alia, the information in question referred to its deliberations. $^{5}$

(2) In the 1998 Interporc I judgment, the Commission said the exception for protection of the public interest relating to court proceedings authorised it, in the context of Decision 94/90, not to make available to the public all documents relating to pending proceedings. ${ }^{6}$

Nonetheless, the Community courts, in particular the CFI, adopted the opposite approach when addressing FOI disputes during the second stage, and established the

\footnotetext{
${ }_{6}^{5}$ Case T-194/94, John Carvel and Guardian Newspapers v. Council [1995] ECR II-2769, para. 73.

${ }^{6}$ Case T-124/96, Interporc Im- und Export GmbH v. Commission [1998] ECR II-231, para. 36.
} 
principle that openness should be the rule and secrecy the exception. ${ }^{7}$

As regards the third stage, namely the period after the Regulation entered into force in late 2001, the Council and the Commission appear very satisfied with how freedom of information is protected in the Union. The Commission said in a report published in 2004 that it was unnecessary to revise this legislation: "Regulation 1049/2001 has been applied for two years and no problems have arisen during implementation that would justify amending [the] legislation for the time being" (emphasis added). ${ }^{8}$ The Council also said in its 2003 FOI report that " $\left.\mathrm{t}\right]$ he Council's experience in connection with the implementation of Regulation No 1049/2001 in 2003 has shown that application of the Regulation's provisions causes no particular problems either with regard to the analysis of documents for which access is requested or with regard to compliance with the response times laid down by the Regulation" (emphasis added). ${ }^{9}$ Is this really the case? Our analysis indicates that it is not. Certainly, the Council and the Commission have generally abandoned the view that secrecy ought to be the rule and openness the exception. Nevertheless, these two institutions, and even the Parliament on occasion, have relied on certain exceptions, or even no exception at all, to deny systematically access to public information. An examination of the 2002 and 2003 Council and Commission FOI

\footnotetext{
${ }^{7}$ We will review the ways the Community courts prevented overbroad interpretation of exceptions during the second stage in the next section. In addition to this effort, the Courts also attempted to extend the scope of freedom of information, which also reflects the view that openness should be the rule and secrecy the exception. See Case T-174/95, Svenska Journalistförbundet v. Council [1998] ECR II-2289, and Case T-14/98, Hautala v. Council [1999] ECR II-2489, and Case C-353/99P, Council v. Hautala [2001] ECR I-9565. These cases have been examined in 3.7 and 3.9.

${ }^{8}$ The Commission adopted this report on 30 January 2004 following the review of the practice of the three major institutions on freedom of information. European Commission, 'Report from the Commission on the Implementation of the principles in EC Regulation No 1049/2001 regarding Public Access to European Parliament, Council and Commission Documents', COM (2004) 45 final (Brussels, 30 Jan. 2004), http://europa.eu.int/eur-lex/en/com/rpt/2004/com2004_0045en01.pdf

9 The Council, Council Annual Report on Access to Documents - 2003 (Brussels, the Council, April 2004), http://ue.eu.int/uedocs/cmsUpload/RapAnCons.en03.pdf, 39.
} 
reports demonstrates the following tendencies. ${ }^{10}$

(1) In 2002 and 2003, most initial applications for Council information relating to international relations appeared to have been refused. ${ }^{11}$

(2) In 2002 and 2003, the public appeared to have been systematically denied access to information in which the opinions of the Council's Legal Service were reproduced. ${ }^{12}$

(3) In 2002 and 2003, the public appeared to have been denied access to information relating to competition on the ground of protection of the "purposes of inspections, investigations and audits". 13

A 2003 Parliament Resolution indicates that: ${ }^{14}$

(1) The Council systematically denies access to information which could identify the positions of the various national delegations at the time of the decision-making process. ${ }^{15}$

(2) The Council appears systematically to refuse applications for documents concerning public security on the basis of Article 4(1) of the

\footnotetext{
${ }^{10}$ The Council, Council Annual Report on Access to Documents - 2002 (Brussels, the Council, April 2003), http://ue.eu.int/uedocs/cmsUpload/EN-AR-02.pdf; The Council, Council Annual Report on Access to Documents - 2003, ibid. European Commission, Report from the Commission on the Application in 2002 of Regulation (EC) No 1049/2001 of the European Parliament and of the Council regarding Public Access to European Parliament, Council and Commission documents, COM(2003) 216 final, (Brussels, European Commission, 29 April 2003), http://europa.eu.int/eur-lex/lex/LexUriServ/site/en/com/2003/com2003_0216en01.pdf; European Commission, Report from the Commission on the Application in 2003 of Regulation (EC) No 1049/2001 of the European Parliament and of the Council regarding Public Access to European Parliament, Council and Commission documents, COM(2004) 347 final, (Brussels, European Commission, 30 April 2004), http://europa.eu.int/eur-lex/lex/LexUriServ/site/en/com/2004/com2004_0347en01.pdf

${ }^{11}$ See 5.2.3.1 A.

12 See 5.2.3.1 B.

${ }^{13}$ See 5.2.4.1.

14 European Parliament resolution on public access to Parliament, Council and Commission documents (implementation of Regulation (EC) No 1049/2001 in the year 2002) (2003/2022(INI)), http://www2.europarl.eu.int/omk/sipade2?PUBREF=-//EP//TEXT+TA+P5-TA-2003-0413+0+D $\mathrm{OC}+\mathrm{XML}+\mathrm{V} 0 / / \mathrm{EN} \& \mathrm{~L}=\mathrm{EN} \& \mathrm{LEVEL}=3 \& N A V=\mathrm{S} \& L S T D O C=\mathrm{Y}$

15 Point 4 of paragraph 4 , n. 14 above.
} 
Regulation. $^{16}$

(3) The Parliament, the Council, and the Commission appear systematically to refuse all applications for legal opinions. ${ }^{17}$

(4) The Commission systematically denies citizens access to correspondence from the Member States in the context of infringement proceedings once the proceedings have been completed or suspended. ${ }^{18}$

In addition, our analysis of the most contentious FOI complaints addressed by the European Ombudsman, demonstrates that:

(1) In terms of the public interest exception relating to legal advice, the Council took the view that systematic refusal of access to legal opinions was compatible with Article 4(2) of the Regulation. It is worth noting that the 2003 Parliament Resolution noted above also indicates that the Council appears to refuse all applications for access to legal opinions.

(2) As regards protection of confidentiality of institutional proceedings, the Council and Commission's invocation of Article 4(3) of the Regulation showed they considered the protection of certain general interests to be more important than that of freedom of information.

These systematic denials consequently surface in a number of distinct documents. The comprehensive review above indicates that systematic refusals based on some exceptions, or no exception whatsoever, have posed a great threat to the entire EU

${ }^{16}$ Point 5 of paragraph 4, n. 14 above.

${ }_{17}$ Point 6 of paragraph 4, n. 14 above.

${ }_{18}$ Point 12 of paragraph 4, n. 14 above. 
FOI regime. Where the institutions misinterpret the exceptions to deny access in a systematic fashion, none of the purposes of the FOI Regulation can be accomplished. How, then, can we improve this regime in an effort to ensure that requests for public information will not be refused on a systematic basis?

\subsection{What can be done?}

The analysis in Chapters 3 to 7 indicates that there is significant room for improvement of the current FOI regime. We have considered four potential remedies that could be, or have been, employed to prevent systematic refusals based on improper interpretation of the exceptions to openness. First of all, the Parliament in its Resolution on public access adopted in 1988, four years before the Commission and the Council adopted the Code of Conduct, stated that future FOI legislation should "contain a precise definition of the nature and scope of the right to information, the exemptions on the grounds of confidentiality, the description of documents intended for internal use". ${ }^{19}$ Fifteen years later, the Parliament made an analogous suggestion in a 2003 Resolution. It said that the 2001 Regulation needed clarification to avoid varying interpretations by the institutions of the exceptions relating to legal opinions, the positions of national delegations, etc. ${ }^{20}$

This proposal seems, at least at first glance, an attractive one, but it has proven extremely difficult to realise. To define clearly all the interests contained in the

\footnotetext{
19 n. 1 above.

20 n. 14 above.
} 
exceptions, such as privacy and public security, has never been easy for any legislator. The study in Chapter 6 reveals that, as regards the clarification of the scope of the exceptions, we can learn little from the domestic FOI laws within or outside the Union. For instance, as to the clarification of the scope of the privacy exception, the term "clearly unwarranted invasion of personal privacy" which is used in U.S. law can be read in a number of different ways, while the Scottish approach does not reduce the vagueness as no definition at all can be found in the Freedom of Information (Scotland) Act. ${ }^{21}$ In addition, even if the EU legislator were to define clearly the interests contained in the exceptions, such definitions could prove problematic if their scope was narrowly drawn. The suggestion by the Parliament is not of great help at present. However, the task of delimiting the exceptions clearly and properly is expected to be less taxing in the future once the Community court and academic writers have contributed further to our understanding of the nature of the exceptions. For example, this thesis has attempted to establish clearly the scope of the exceptions relating to inspection, investigation, and court proceedings, discussed further at 8.2.3, below.

Additionally, three interrelated proposals have been put forward in this thesis to address the problem of systematic denials. First, the EU legislator should consider removing the unclear dividing line between the exceptions set out in Article 4(1) and Article 4(2) in the 2001 Regulation. Second, we suggest that the Community court alter its views on the invocation of the non-disclosure exception laid down in Article 4(5) of the Regulation. Third, the EU legislator should consider expressly incorporating the principle of proportionality into the Regulation. We will review these suggestions in the following subsections.

${ }^{21}$ See 6.3.2. 
This is an appropriate moment to reassess how the 2001 Regulation could be amended, particularly given that the status of the Treaty establishing a Constitution for Europe remains uncertain. In this Constitutional Treaty, the FOI protection provision is not in a section entitled "internal proceedings". The Constitutional Treaty incorporates the Charter of Fundamental Rights of the Union in its Part II, recognising the right of access to documents as a fundamental right. Article $\Pi-102$ extends the scope of EU FOI protection to cover the documents of not only the Council, the Commission, and the Parliament, but all "the institutions, bodies, and agencies of the Union". Articles I-50 and Ш-399 of this Treaty, as we saw in 5.8.5, reconfirm this extension. ${ }^{22}$

The Constitutional Treaty is also important because of the emphasis it places on active participation by citizens in the democratic process. Thus, Articles I-50, $\Pi-102$, and Ш-399 of the Constitutional Treaty enhance the role of the principle of participatory democracy in the Union, a principle laid down in Article I-47 of this Treaty. Article I-47(1) requires that the institutions of the Union give citizens and representative associations the opportunity to exchange their views in all areas of Union action. Under Article I-47(2), the institutions should maintain a transparent and regular dialogue with representative associations and civil society. An extended right of access to documents is intended to enrich the exchange of views and dialogues, allowing EU citizens to be more familiar with and to make more informed comments on the operation of the Union. All these rules are designed to help EU citizens play a more significant part in the democratic life of the Union, thereby increasing their sense of security and presumably helping to hold them together.

However, Articles I-50, II-102, and Ш-399 of the Constitutional Treaty do not

${ }^{22}$ For text of Articles I-50, II-102, and III-399, see 5.8.1 and 5.8.5. 
address the question of how to prevent systematic refusals. We believe that review of the major lessons learned over the last two decades, in particular the various ways in which improper interpretation of exceptions to openness can be avoided, will be beneficial when considering how best to amend the Regulation.

\subsubsection{Removal of an indistinct distinction}

There seemed to be a clear distinction between the two categories of exceptions set out in the Code of Conduct. The first category of exceptions appeared to be mandatory and the other discretionary. As to the first category of exceptions, section 4, subsection 1 of the Code of Conduct stated that, the Council and the Commission "will refuse access to any document whose disclosure could undermine" the protection of certain public interests, as well as privacy, and commercial secrecy, etc. According to section 4, subsection 2, the two institutions "may also refuse access in order to protect the institution's interest in the confidentiality of its proceedings". In the $W W F$ judgment, the CFI said that the first category, comprising the "mandatory exceptions", protected the interest of third parties or of the general public, while "in the second category, relating to the internal deliberations of the institution, it is the interest of the institution alone which is at stake". ${ }^{23}$ This distinction was questionable because the internal deliberations of the EC authorities often have a close relationship not only with the interest of the institution but also with that of the general public.

The case law also indicates that the distinction between these two provisions

${ }^{23}$ para. 60, Case T-105/95, WWF (United Kingdom) v. Commission [1997] ECR II-313. 
was not at all clear. This is because the Council and the Commission were under analogous obligations to balance relevant interests or to give adequate reasoning for their refusals when invoking the first, second, or both categories of exemption. In the 1995 Carvel judgment, the CFI stated that the Council had to carry out the interest balancing test when invoking a discretionary exception in Article 4(2) of Council Decision 93/731, namely the second category exception. ${ }^{24}$ In the 1998 Svenska Journalistförbundet judgment, the CFI stated that the terms of a refusal of access must permit the applicant and the Court to check whether the institution concerned had conducted the balancing test when invoking Article 4(2), otherwise the institution would have failed to comply with the requirement to give reasons laid down in Article 190 EC (now Article 253 EC). ${ }^{25}$ These two judgments indicate that where the Council or the Commission invokes an exception in the second category, the balancing test and Article 253 EC must be complied with.

However, this does not mean that the two institutions were entitled to deny access by invoking a first category exception without being subject to any legal principles. The Community court has assessed the legality of refusals based on the first category exceptions by reference to Article $253 \mathrm{EC}$, and the principle of proportionality. As to Article $253 \mathrm{EC}$, according to the $1997 \mathrm{WWF}$ judgment, where the Commission invoked the public interest exception relating to infringement proceedings, i.e. a first category exception, the Court held the Commission must indicate the reasons why it considered that the requested documents were related to the possible opening of an infringement procedure. ${ }^{26}$ In the 1998 Interporc $I$ judgment, the CFI stressed that a Commission decision based on a first category

\footnotetext{
${ }^{24}$ paras. 65 and 67, n. 5 above.

${ }^{25}$ paras. 125 and 127, n. 7 above.

26 para 64, n. 23 above.
} 
exception, here the public interest exception relating to court proceedings, "must state the reasons on which it is based, in accordance with [Article $253 \mathrm{EC}$ ]" ${ }^{27}$ The CFI reiterated these requirements of Article 253 in the 1998 Carlsen case, which dealt with a dispute over an invocation of the public interest exception relating to legal opinions. ${ }^{28}$ As regards the proportionality principle, the CFI in the Hautala, Kuijer, and Mattila judgments between 2001 and 2003 required refusals based on another first category exception, the public interest exception relating to international relations, to be proportionate. ${ }^{29}$

The employment of Asticle 253 EC and the principle of proportionality in the rulings above indicates that the Court attached importance to the phrase "could" in section 4 , subsection 1 of the Code of Conduct, highlighting the obligation of the institutions to consider whether the public interests could be jeopardised. As these judgments required that invocations of the first category exceptions were subject to Article 253, and the proportionality principle, it is fair to say that the Court narrowed down the scope of the mandatory exceptions to a significant extent. In brief, as the Council and Commission had to consider one or more of the legal principles noted above when invoking exceptions in the first or second category, the distinction between the two became blurred.

Have these difficulties now been resolved by the 2001 Regulation? The answer is "no" in that it is possible to see very similar disputes arising under the Regulation. Article 4(1) of the 2001 Regulation is intended to guarantee the public interest, as well as privacy and the integrity of the individual, while Article 4(2) seeks to ensure

\footnotetext{
27 para. 53, n. 6 above.

28 para. 5, Case T-610/97, Carlsen and others v. Council [1998] ECR II-485.

29 The Hautala judgment, n. 7 above; Case T-211/00, Aldo Kuijer v. Council [2002] ECR II-485; Case T-204/99, Olli Mattila v. Council and Commission [2001] ECR II-2265, and Case C-353/01, and Olli Mattila v. Council and Commission [2004] ECR I-0000.
} 
the protection of commercial interests, court proceedings, legal advice, as well as the purpose of inspections, investigations and audits. Similarly, there seems to be a distinction between Article 4(1) and Article 4(2), because the latter has a condition, namely "unless there is an overriding public interest in disclosure". This requirement could prove problematic in the future because Article 4(1) of the Regulation does not contain a similar requirement. The three institutions might consider that a request for access can be refused on the basis of Article 4(1) even if there is a competing public interest in disclosure. The institutions could make this misinterpretation without noticing that, according to the spirit of the case law, invocation of the exceptions set out in Article 4(1) of the Regulation should be in line with the requirement to give adequate reasoning in Article $253 \mathrm{EC}$ and with the principle of proportionality. Thus, this additional condition is potentially misleading and should be removed from the 2001 Regulation. Instead, the principle of proportionality should be explicitly incorporated into the legislation so as to apply to all the stipulated exceptions. This suggestion is discussed in detail at $\mathbf{8 . 2 . 4}$ below. In addition, Article 253 EC will continue to be important in this area, because it may still be used to challenge a refusal either on its own, or jointly with the principle of proportionality.

\subsubsection{The non-disclosure provision}

The analysis of the Petrie and Interporc II judgments suggests that the authorship rule ran counter to the principle of widest possible access set out in the Code of 
Conduct. ${ }^{30}$ This is because, on the one hand, the Council and the Commission had no power to decide to disclose third party information and, on the other, third parties tend to be unwilling to approve a request for access in circumstances where their interests are at stake. It is then very difficult for an applicant to access public information originating from a third party, which renders the principle of widest possible access an empty commitment.

The authorship rule is not included in the 2001 Regulation. But is there an analogous provision in this measure? Fortunately, the answer here is no. Although Article 4(5) of the Regulation relates to a new exception to openness, this provision is very different from the authorship rule set out in the Code of Conduct. Our analysis showed that under Article 4(5), the Council, the Commission, and the Parliament are not bound by the requests from the Member States. In the 2003 Messina and 2004 Internationaler Tierschutz-Fonds judgments, however, the CFI ignored this compelling feature. ${ }^{31}$ Unless the Court alters its approach, this could lead to disputes over the invocation of the non-disclosure rule. In addition, the EU legislator should consider revising this provision, requiring that the three institutions apply the principle of proportionality whenever a Member State expresses opposition to the release of information.

\subsubsection{The exceptions regarding investigations, inspections, and court proceedings}

The case law indicates that the purpose behind the public interest exceptions relating

\footnotetext{
${ }^{30}$ Case T-191/99, David Petrie, Victoria Jane Primhak, David Verzoni and Others v. Commission [2001] ECR II-3677, and Case C-41/00, Interporc Im- und Export GmbH v. Commission [2003] ECR I-2125.

${ }^{31}$ Case T-76/02, Mara Messina v. Commission [2003] ECR 0000, and Case T-168/02, IFAW Internationaler Tierschutz-Fonds gGmbH v. Commission [2004] ECR 0000.
} 
to investigations, inspections, and court proceedings set out in the Code of Conduct, as well as corresponding Council Decision 93/731, and Commission Decision 94/90 was unclear. The main controversy is whether these exemptions can be invoked merely to guarantee the privilege for lawyers and the right to a fair hearing, or mainly to secure an amicable resolution of a dispute before the Community court delivers a judgment? In van der Wal, the Court was of the opinion that the court proceedings exception enshrined in Decision $94 / 90$ was designed to ensure respect for the right to a fair hearing. ${ }^{32}$ However, in the 2001 Petrie judgment the CFI went further and said that the Commission was entitled to invoke these exemptions to preserve an amicable resolution of the dispute between the Commission and the Member State concerned, i.e. the Italian Republic, before the Community court has delivered its judgment. ${ }^{33}$ Certainly, an amicable resolution could be of interest to the public, but a close causal link does not always exist between a refusal and an amicable resolution. In Petrie, an invocation of the exception, i.e. a refusal of access to the documents relating to the Italy-Commission dispute, would preserve the secrecy of the infringement proceedings. However, in other disputes between a Member State and the Commission, it cannot be ruled out that certain information relating to the disputes may be released by one or both parties before court proceedings. Where relevant information is already available to the public, it is no longer sensible to deny access on the basis of the exception in the name of preserving an amicable resolution. Thus, pursuit of an amicable resolution should not be recognised as a main purpose of the court proceedings exception. Otherwise, the

\footnotetext{
32 para. 48, Case T-83/96, Gerard van der Wal v. Commission [1998] ECR II-545, and Joined cases C-174/98 and C-189/98, Kingdom of the Netherlands and Gerard van der Wal v. Commission [2000] ECR I-0001.

${ }_{33}$ para. 68 , n. 30 above.
} 
institutions could employ such a broad interpretation of the scope of the exception to refuse relevant requests systematically.

In the 2003 Interporc II judgment, the CFI altered the view it had expressed in Petrie, and this was then endorsed by the ECJ. ${ }^{34}$ The CFI stated that "the expression 'court proceedings' must be interpreted as meaning that the protection of the public interest precludes the disclosure of the content of documents drawn up by the Commission solely for the purposes of specific court proceedings". ${ }^{35}$ As court proceedings are intended mainly to ensure the enforcement of Community law rather than an amicable resolution of disputes, access to documents drawn up for preserving an amicable resolution must not be denied under the public interest exceptions relating to investigations, inspections, and court proceedings.

Unfortunately, the 2001 Regulation does not clarify this issue further. According to Article 4(2) of the Regulation, the three institutions shall refuse access to a document where disclosure would undermine the protection of, inter alia, "court proceedings and legal advice", and "the purpose of inspections, investigations and audits", unless there is an overriding public interest in disclosure. The EU legislator should consider revising Article 4(2) of the Regulation, to reflect the conclusions of the van der Wal and Interporc II cases. Our proposal is:

The EU authorities shall refuse access to a document where disclosure would undermine the protection of court proceedings, legal advice, inspections, investigations and audits, but only to the extent that the reproduction (A) could reasonably be expected to invade the privileges for lawyers, or (B) would deprive a person of his or her right to a fair hearing.

\footnotetext{
34 n. 30 above.

35 para. 40 , n. 30 above.
} 


\subsubsection{Explicit incorporation of the principle of proportionality into the FOI Regulation}

\subsubsection{Relevant rules}

We have seen that during the second and third stages of the evolution of FOI protection in the Union, both the Council and Commission constantly interpreted certain exemptions in a very broad manner before the Community court. Indeed, no rule in the Code of Conduct, the two corresponding Council and Commission decisions, or, now, the FOI Regulation expressly prohibits these two institutions from doing so. Nevertheless, four rules or principles have been employed by applicants and the Court to afford the exceptions a narrow interpretation.

(1) The principle of "widest possible access" set out in the first section of the Code of Conduct and Article 1(a) of the 2001 Regulation;

(2) Section 4, subsection 2 of the Code of Conduct. Under this provision, the Council and the Commission "may also refuse access in order to protect the institution's interest in the confidentiality of its proceedings". This provision was held by the Court to require a balancing test, ${ }^{36}$ prohibiting the two institutions from denying access in a systematic fashion.

(3) The obligation to give adequate reasoning laid down by Article $253 \mathrm{EC}$ (former Article $190 \mathrm{EC}$ );

(4) The principle of proportionality.

These rules perform analogous functions to the extent that each of them helps to

${ }^{36}$ See 3.2.3. 
ensure that the exceptions to openness are properly delimited. This is the reason why they have been used individually or jointly to counter misinterpretation of the exceptions. Nonetheless, the analysis in the preceding chapters indicates that the effect of the first three rules has been partial or unstable in the FOI field.

First of all, with regard to the principle of "widest possible access", the CFI stated in the 1995 Carvel case, the first key FOI decision during the second stage, that the objective of Council Decision 93/731 was "to allow the public wide access". ${ }^{37}$ In the 1997 WWF judgment, the CFI stressed the importance of this principle, noting that where a general principle was established and exceptions to that principle were laid down, the exceptions should be construed and applied strictly, in a manner which would not defeat the application of the general rule. ${ }^{38}$ Nevertheless, the principle of widest possible access lacks specificity. It remains unclear what the scope of "widest possible access" is and what legal tests this principle requires. For the applicants whose requests are refused, this principle has not been, and is not expected to be, of great help when they challenge refusals to provide information.

Secondly, Section 4, subsection 2 of the Code of Conduct was held by the Court to require a balancing test. In the Carvel judgment, the CFI elaborated on this test, noting that the Council was obliged to balance the citizens' interest in accessing Council documents against its interest in maintaining the confidentiality of its proceedings. ${ }^{39}$ In the $W W F$ case, the CFI held that the Commission had failed to fulfill its duty to undertake the balancing test. ${ }^{40}$ In Svenska Journalistförbundet, the CFI was of the view that the information in the contested decision was insufficient

\footnotetext{
37 para. 65, n. 5 above.

38 para. 56, n. 23 above.

39 paras. 65 and 67, n. 5 above.

40 para. 70 , n. 23 above.
} 
for the applicant or the Court to check whether the Council had complied with its duty to carry out the balancing test as the application of Article 4(2) of Decision $93 / 731$, i.e. the second category exception, requires. ${ }^{41}$ Nonetheless, the role of the balancing test in EU FOI protection has long been limited. Under the framework of the Code of Conduct, the balancing test did not apply to the first category of exemptions or the authorship rule. At present, the balancing test can be found in Article 4(2) of the 2001 Regulation. Under this provision, the Council, the Commission, and the Parliament shall refuse access to a document where disclosure would undermine the protection of commercial interests, court proceedings, legal advice, as well as the purpose of inspections, investigations and audits, "unless there is an overriding public interest in disclosure". However, the balancing test does not apply to Article 4(1) or the non-disclosure provision as they do not contain a similar provision.

The requirement of giving adequate reasoning is laid down in Article $253 \mathrm{EC}$, which demands that the Council and Commission specify the source of legal authority for a refusal before indicating the objectives that the refusal is to achieve. In addition, the institutions should also indicate the reasons why it is desirable to accomplish those objectives. The CFI in the $W W F$, the Interporc $I$, and the Rothmans judgments stated that the Commission's refusals of access to the requested documents should have provided sufficient reasons as set out in Article 253. Nevertheless, this provision is insufficient to secure freedom of information in the Union. This is because the CFI has not adopted a consistent approach when interpreting the terms "sufficient reasons" and "adequate reasoning".

The CFI stated in Interporc $I$ that it had consistently held that "the reasoning

\footnotetext{
${ }^{41}$ para. 125 , n. 7 above.
} 
required by that provision must show clearly and unequivocally the reasoning of the Community authority which adopted the contested measure so as to enable the persons concerned to ascertain the reasons for the measure in order to protect their rights, and the Court to exercise its power of review". ${ }^{42}$ The CFI reiterated these requirements of Article 253 in the 1998 Carlsen case. $^{43}$

However, the CFI did not hold a firm stance when applying the requirement of clear and unequivocal reasoning in its Carlsen and van der Wal judgments. In Carlsen, the CFI failed to examine whether the Council had adequately established why release of the specific information requested could damage "the maintenance of legal certainty and the stability of Community law" and "the Council's being able to obtain independent legal advice". ${ }^{4}$ It was unclear which sub-concepts of legal certainty, such as non-retroactivity, the protection of vested rights, and legitimate expectations could be damaged by disclosure. Although these two reasons were not at all clear, the CFI held that they "must be considered to be sufficient". ${ }^{45}$ In van der Wal, the Commission refused the request "on the ground that disclosure of the replies could undermine the protection of the public interest and, more specifically, the sound administration of justice" (emphasis added). ${ }^{46}$ This was not clear and unequivocal reasoning. On the one hand, it is uncertain what sound administration of justice refers to and what can be done to protect it. On the other hand, the Commission failed to establish why disclosure of the information at issue would jeopardise the sound administration of justice. The CFI, however, stated that the

\footnotetext{
${ }^{42}$ para. 53, n. 6 above.

43 para. 5, n. 28.

44 paras. 4 and 5, n. 28 above.

${ }_{45}$ para. 4 , n. 28 above.

46 para. 15, n. 32 above.
} 
reasoning presented by the Commission was sufficiently clear. ${ }^{47}$

In the 1998 Svenska Journalistförbundet judgment, however, the CFI insisted on the clear reasoning obligation and adopted a stricter approach. In this case, the Council did not balance "on the one hand, the interest of the citizens seeking the information and, on the other hand, the criteria for confidentiality of the proceedings of the Council". ${ }^{48}$ As a result, the CFI held that that the contested decision did not comply with the requirements for reasoning laid down in Article $253 .^{49}$

It can be concluded therefore that the principle of "widest possible access", the balancing test, and the requirement to give adequate reasoning are not comprehensive in scope, nor have they been applied consistently.

\subsubsection{Is proportionality a better choice?}

The principle of proportionality is more likely to be an effective principle of review across the EU FOI field. This doctrine should help the public counter overbroad interpretations of exceptions in a more effective way. We suggest that the EU legislator include an explicit reference to the principle of proportionality in the 2001 Regulation. This proposed provision requires that (A) the proportionality test be applied when any of the exceptions set out in the Regulation are invoked, and (B) the way this test has been applied in practice should be expressly indicated in any refusal. This principle places great emphasis on a reasonable relationship between the ends and the means. As regards freedom of information, the end is to maintain the various interests protected by the exceptions to openness, while the means is a refusal of a request for access to information held by the $\mathrm{EC}$ institutions.

${ }^{47}$ para. 71, n. 32 above.

${ }_{48}$ para. $125, \mathrm{n} .7$ above.

49 paras. 125 and 127, n. 7. 
The CFI introduced the principle of proportionality into this area in the 2001 Hautala judgment. ${ }^{50}$ In two FOI disputes that were subsequently addressed by the Court, namely Kuijer and Mattila, it was held that the Council was obliged to consider this principle when refusing access to documents. ${ }^{51}$ Why, though, should the legislator labour to introduce the proportionality doctrine in the Regulation, when the Courts have already stated that it is a general principle of Community law? The main reason is that the Courts' position towards this requirement has been far from satisfactory. To be specific, following examination of the Hautala, Kuijer, and Mattila cases, it appears that the Court did not establish that the Council, the Commission, and the Parliament were obliged to consider the principle of proportionality when invoking all the exceptions set out in the 2001 Regulation.

Article 220(1) EC states that "[t]he Court of Justice and the Court of First Instance, each within its jurisdiction, shall ensure that in the interpretation and application of this Treaty the law is observed". It is usually thought that here the scope of the phrase "law" refers to, inter alia, the Treaty and general principles. ${ }^{52}$ As the role of this principle has been recognised both at Treaty level, namely in Article 5(3) EC, and in the case law as a general principle, the Court is obliged to ensure the principle of proportionality is observed. However, the Court has considerable latitude in ensuring that the general principles, including the principle of proportionality, are observed since these principles are loosely worded in the Treaty. ${ }^{53}$ In the EU FOI field, the Court made proportionality reviews only in the Hautala, Kuijer and Mattila judgments. Neither the public nor the three institutions benefit from the selective use

\footnotetext{
${ }^{50}$ n. 7 above.

${ }^{51}$ n. 29 above.

${ }^{52}$ T. Hartley, The Foundations of European Community Law ( $5^{\text {th }}$ edn., Oxford, Oxford University Press, 2003), 134. S. Weatherill, Cases and Materials on EU Law (6 ${ }^{\text {th }}$ edn., Oxford, Oxford University Press, 2004), 89-92.

${ }^{53}$ Weatherill, n. 52 above, at 92.
} 
of this principle which has resulted in significant uncertainty in this area. The two negative dimensions of this uncertainty can be summarised in the following way.

On the one hand, the lack of an express provision establishing the principle of proportionality could prejudice those who request access to public information. In the Petrie and Messina cases, the Council and the Commission failed even to think of this principle in their refusals. What was worse was that in Verein für Konsumenteninformation $v$. Commission (hereinafter the " $V K T$ ' case) the Commission in a refusal attempted to justify its failure to carry out a concrete, individual examination of the numerous documents in question by reference to the principle of proportionality. The CFI held that this refusal constituted "a manifest breach of the principle of proportionality", because a concrete, individual examination helps the Commission to identify "the only documents covered, in whole or in part," by exceptions set out in the 2001 Regulation. ${ }^{54}$ In addition, it bears noting that all the Hautala, Kuijer, and Mattila cases concerned the same exception, i.e. the public interest exception relating to international relations. Is an applicant entitled to challenge a refusal based on the other exceptions where the EU institution similarly fails to consider this principle? There is, of course, no reason why the proportionality doctrine should not apply to invocations of other exceptions given that it is well established as a general principle of Community law, but with incorporation of proportionality into the Regulation, there would no longer be a risk that where an institution invokes an exception other than the international relations exception, it might seek to avoid application of the proportionality test.

On the other hand, this uncertainty is not at all beneficial to any of the three

\footnotetext{
${ }^{54}$ paras. 97-100, Case T-2/03, Verein für Konsumenteninformation v. Commission [2005] ECR II-0000.
} 
Community institutions. Although the Court has applied the proportionality principle mainly in relation to the international relations exception, it is likely that, if refusals are referred to the Court, the judges would extend its application to other exceptions. In fact, in its $2005 V K I$ judgment, the CFI applied the principle of proportionality to a general refusal based on "one or more of the exceptions provided for by Regulation No 1049/2001". ${ }^{55}$ All refusals, where the principle of proportionality had not been considered, could now be annulled. This imposes continuing pressure on the Council, Commission, and Parliament. Incorporation of proportionality into the Regulation, which would provide the institutions with clear guidelines, would remove any remaining uncertainty.

\subsubsection{FOI and the role of proportionality in EU law}

Our analysis indicates that an explicit propultionality provision would be beneficial to FOI protection in the Union. But is it really worth introducing proportionality explicitly into the 2001 Regulation, when this doctrine is well established as a general principle in Community law? To answer this question, we must look in more detail at the role of proportionality in the EC Treaty and in the case law.

The principle of proportionality was inserted into the EC Treaty by the Maastricht amendments. The term proportionality is not used explicitly in the EC Treaty but Article 5(3) EC captures its essence, stating that "[a]ny action by the Community shall not go beyond what is necessary to achieve the objectives of this Treaty" (emphasis added). This is a rule of coercive nature, but this provision alone does not guarantee appropriate FOI protection. On the one hand, under Article 5(3) $\mathrm{EC}$, the three institutions are not obliged to indicate how they apply the

${ }^{55}$ para. 18, n. 54 above. 
proportionality principle when refusing access to information. This means that where an institution fails to apply this principle, it may be extremely difficult for applicants to identify this failure, let alone challenge the refusal. Article $253 \mathrm{EC}$ which lays down the obligation to give clear reasoning does not help resolve this problem. In reality, the case law indicates that the Court has not held that application of the principle of proportionality constitutes a part of the duty to give clear reasons.

The case law on the principle of proportionality does not help much in strengthening FOI protection in the Union. First, as under Article 5(3) EC, the case law does not require that the three institutions indicate how they apply the proportionality principle in their refusals. Second, an applicant can seek annulment of a refusal on the ground that it breaches the proportionality principle without needing to refer to Article 5(3) EC, but the case law shows that the Court assessed the legality of refusals on the basis of the principle of proportionality only when the public interest exception relating to international relations was involved. Though well established in Community law, the spirit of the proportionality doctrine has not yet been realised in the FOI field.

To introduce proportionality explicitly into the 2001 Regulation would enhance its role in EU FOI protection. On the one hand, this proposed incorporation would ensure that the purpose of Article 5(3) EC was met in this field, because it would require that the institutions indicate how this principle was applied when approving or refusing a request for access to documents. On the other hand, where the proportionality doctrine applies to every exception in this Regulation, it will no longer be appropriate for the Court to confine such review to invocations of the international relations exception. 
What must then be considered is the intensity with which the Court should apply the proportionality test to future FOI disputes under this proposed provision. This is a subject of considerable importance, because such a provision would be an empty statement if the institutions were to apply it in a marginal and undemanding fashion. It would not be surprising at all if the Council and the Commission, in particular the former, were to attempt to read this principle narrowly because, first, these two institutions, as we have seen, have a long record of interpreting the balancing test and the Article 253 test in a limited manner. Second, the institutions may seek to make use of the fact that the Community court has not adopted a consistent approach in the application of this principle. As Professor Takis Tridimas has said, "[f]ar from dictating a uniform test, [the principle of proportionality] is an open-textured principle which is used in different contexts to protect different interests, and it entails different degrees of judicial scrutiny". ${ }^{56}$ Illustrations can be found in the field of EC agricultural law, in which this principle has exerted particular influence. ${ }^{57}$ In this area, the position of the ECJ has varied when assessing the legality of Community acts according to this principle. Advocate General Francis Jacobs has noted that "in reviewing more general legislative measures involving an element of policy the Court has been perhaps less exacting". ${ }^{58}$ Thus, in the 1990 Fedesa judgment, which concerned the validity of a Council Directive prohibiting the use in livestock farming of certain hormones, the ECJ only exercised a limited

\footnotetext{
${ }^{56}$ T. Tridimas, 'Proportionality in European Community Law: Searching for the Appropriate Standard of Scrutiny,' in E. Ellis (ed.), The Principle of Proportionality in the Laws of Europe (Oxford, Hart Publishing, 1999), 84.

57 Advocate General Francis Jacobs says that "[w]here Community measures are concerned, the agricultural sector provides the best illustration of the current application of the principle [of proportionality], since it is in that sector that the Community legislature is most active. F. Jacobs, 'Recent Developments in the Principle of Proportionality in European Community Law,' in Ellis, $n$. 56 above, at 3 .

58 Jacobs, ibid. Professor Tridimas has also said that "[i]n relation to market regulation measures, the Court applies a loose test of proportionality". Tridimas, n. 56 above, at 70 .
} 
review of the Council's application of the proportionality test in adopting the Directive. ${ }^{59}$ Nonetheless, in other areas the ECJ exercised an intensive form of review as illustrated by the 1991 Werner Faust and Wünsche judgments. ${ }^{60}$ Professor Tridimas has said that these two judgments "illustrate a strict application of the principle of proportionality. They established that, in applying protective measures, the Commission must choose the alternative which is least restrictive of commercial freedom" ${ }^{61}$ As the proportionality principle is applied by the Court with ranging degrees of intensity, it would not be surprising if the Council and Commission applied the principle of proportionality in a marginal manner when refusing requests for access to information. The institutions could defend such an application on the ground that the Court has allowed for a less exacting standard of judicial review depending on the context and character of the act under review. Therefore, these institutions might attempt to interpret the principle of proportionality in the way they favour, rendering the test less effective.

\footnotetext{
${ }^{59}$ Case C-331/88, The Queen v. Minister of Agriculture, Fisheries and Food and Secretary of State for Health, ex parte: Fedesa and others [1990] ECR I-4023. The measure concerned was Council Directive of 7 March 1988 prohibiting the use in livestock farming of certain substances having a hormonal action (88/146/EEC) OJ L70/16. The Court held that the prohibition at issue was not manifestly inappropriate. para. 15. It held that this prohibition was not manifestly inappropriate, mainly because it was not obvious whether the authorisation of the hormones could "prevent the emergence of a black market for dangerous but less expensive substances". It did not concentrate on whether the prohibition concerned was manifestly appropriate so that the objective of the Directive, namely to remove trade barriers, could be attained through the prohibition at issue. According to Recitals 1 and 2 of the Directive at issue, the purpose of this measure was to remove the distortions of competition and barriers to trade resulting from the fact that the administration to farm animals of certain substances having a hormonal action was regulated differently in the Member States.

${ }^{60}$ Case C-24/90, Hauptzollamt Hamburg-Jonas v. Werner Faust Offene Handelsgesellschaft KG [1991] ECR I-4905; Case C-25/90, Hauptzollamt Hamburg Jonas v. Wünsche Handclsgesellschaft GmbH \& Co. KG [1991] ECR I-4939. Both disputes concerned the validity of a protective measure in a Regulation applicable to imports of preserved mushrooms. The measure in question in these disputes was Commission Regulation (EEC) No 3429/80 of 29 December 1980 adopting protective measures applicable to imports of preserved mushrooms OJ L358/66. The ECJ analysed the measure's objective and its serious effects, i.e. a considerable financial charge for importers, in a very comprehensive manner according to the principle of proportionality: paras. 11-30 of the Werner Faust judgment, and paras. 12-31 of the Wünsche judgment. Following this thorough review, the Court concluded that such a measure was disproportionate in relation to the objective pursued by the Regulation and was therefore invalid: paras. 26, and 30 of the Werner Faust judgment.

${ }^{61}$ Tridimas, n. 56 above, at 74.
} 
The Court should apply an intensive form of proportionality review when considering future FOI disputes. The first reason is that the Court applied the proportionality principle strictly in the Hautala, Kuijer, and Mattila judgments between 2001 and $2004 .{ }^{62}$ Where the use of proportionality extends to invocation of exceptions other than the international relations exception, there is no reason why the strictness with which the Court applies this principle should differ. Secondly, the Court has employed an intensive form of review when considering whether Community measures disproportionately restrict individual rights. Professor Gráinne de Búrca noted in 1993 that the ECJ and CFI "are generally prepared to adjudicate on issues involving traditionally categorised individual rights, where interference with a discretionary policy decision can be explained not on the ground that it is not the most sensible or effective measure, but on the ground that it unjustifiably restricts an important legally recognised right, the protection for which is entrusted to the court". ${ }^{63}$ The development in the case law after 1993 corresponds to this tradition. ${ }^{64}$ As we have seen in Chapters 3 to 7 , freedom of information has long been recognised as an important individual right in the Union after the adoption of the Code of Conduct, and it could be recognised as a fundamental right by a revised or future Treaty. To be consistent with the strict approach it has adopted in the protection of individual rights and with FOI cases to date, the Court should adopt an

\footnotetext{
${ }^{62}$ n. 7 and 29 above.

${ }^{63}$ G. de Búrca, 'The Principle of Proportionality and its Application in EC Law,' in A. Barav and D. Wyatt (eds.), Yearbook of European Law vol. 13 (Oxford, Clarendon Press, 1993), 111. This view is evident in the case law, See, for example, Case 44/79, Liselotte Hauer $v$. Land Rheinland-Pfalz [1979] ECR 3727, paras. 23-33, and Case 5/88 Hubert Wachauf v. Bundesamt für Ernährung und Forstwirtschaft [1989] ECR 2609, paras. 18-24.

${ }^{64}$ Case C-84/95, Bosphorus Hava Yollari Turizm ve Ticaret AS v. Minister for Transport, Energy and Communications and others [1996] ECR I-3953, paras. 22-26. This dispute concerned whether the sanctions laid down in a Council Regulation affecting the right to property and the freedom to pursue a trade or business constituted a breach of the principle of proportionality.
} 
intensive form of proportionality review of FOI disputes if the proportionality doctrine is incorporated into the Regulation.

\subsection{The challenges}

A proposal to extend EU FOI protection can be found in the Treaty establishing a Constitution for Europe. What is the fundamental difference between this proposal and Article $255 \mathrm{EC}$ with respect to the scope of public scrutiny? Under Article 255 EC, the public was capable of scrutinising the operation of the EC executive and legislature through access to public documents. Under Articles I-50, II-102, and III-399 of this Treaty, a wide range of the administrative, legislative, executive, and judicial functions of the Union are put under democratic scrutiny through the exercise of this fundamental right. Although the ratification of this Treaty was unsuccessful in France and the Netherlands, a further attempt to extend FOI protection remains absolutely necessary since it is an effective way to ensure that any future European integration takes place subject to public scrutiny. As regards the beneficiaries of freedom of information, under the proposal, this right is reserved to any citizen of the Union, and any natural or legal person residing or having its registered office in a Member State. This wording is exactly the same as that in Article 255 EC. Article 2(2) of the 2001 Regulation states that the Council, the Commission, and the Parliament may "grant access to documents to any natural or legal person not residing or not having its registered office in a Member State". The 
Council and the Commission amended their Rules of Procedure to extend this right to all natural and legal persons, while the Parliament makes their decisions on a non-discriminatory basis. These achievements should be reflected in the Regulation.

Articles I-50, II-102, III-399 of the Constitutional Treaty were designed to extend the scope of EU FOI protection but it made no attempt to improve the way this right is guaranteed. This study focuses on strengthening the role of proportionality in this area to elevate the level of FOI protection. We believe that our proposal will help secure this right, but the approach of the five institutions and presumably other EU agencies towards proportionality will continue to be decisive. It is doubtful whether the Commission, Council, and Parliament will work together to introduce this principle into the 2001 Regulation, because it operates to prevent the institutions from making excessively broad interpretations of the exceptions set out in this legislation.

Even if such a provision were to be introduced this would not necessarily ensure that the three institutions, in particular the Council and Commission, would never misinterpret the exemptions. However, with an explicit provision on proportionality, we can expect the Court and the Ombudsman to play more active roles in this area. As the proposed provision requires that (A) the proportionality test should be applied when any of the exceptions set out in the Regulation are invoked, and (B) the way this test is applied shall be expressly indicated in the refusal, the Court and the Ombudsman will have clear guidelines to follow when assessing the legality of refusals. In addition, were this proposal to be accepted by the EU legislator, we believe that the Court would apply an intensive form of proportionality review of future FOI disputes because the judges have done so previously in the FOI area and when protecting other individual rights. 


\section{Bibliography}

Academy of European law (ed.) (1999), Collected Courses of the Academy of European Law vol. VII, Book 1 (The Hague: Kluwer Law International).

Armull, A. (1999), The European Union and its Court of Justice (Oxford: Oxford University Press).

- - and Wincott, D. (eds.) (2002), Accountability and Legitimacy in the European Union (Oxford: Oxford University Press).

Barav, A., and Wyatt, D. (eds.) (1993), Yearbook of European Law vol. 13 (Oxford: Clarendon Press).

Barker, R. (2003), 'Legitimacy, Legitimation, and the European Union: What Crisis?' in Craig and Rawlings (2003): 158-174.

Betten, L., and Grief, N. (1998), EU Law and Human Rights (Essex: Longman).

Birkinshaw, P. (1998), 'Review of V. Deckmyn and I. Thompson (eds.), Openness and Transparency in the European Union', 4 European Public Law 613.

- (2001), Freedom of Information, The law, the Practice and the Ideal, $3^{\text {rd }}$ edn. (London: Butterworths).

- (2003), European Public Law (London: Butterworths).

Black, I. (2000), 'Fury as Envoys Vote for Military Secrecy' The Guardian (Manchester: the United Kingdom, 27 July 2000), available at: http://www.guardian.co.uk/international/story/0,3604,347451,00.html

Bomberg, E., Cram, L., and Martin, D. (2003), 'The EU's Institutions' in Bomberg and Stubb (2003): 43-68. 
- - and Stubb, A. (eds.) (2003), The Europcan Union: How Does it Work? (Oxford: Oxford University Press).

Bonnor, P. (2003), 'Ombudsman and the Development of Public Law', 9 European Public Law 237

Borchardt, K.-D. (2000), The ABC of Community Law, $5^{\text {th }}$ edn. (Brussels: European Commission).

Broberg, M. (2002), 'Access to Documents: a General Principle of Community Law?', 27 European Law Review 194.

Chiti, E. (1998), 'Case T-105/95, WWF UK (World Wide Fund for Nature) v. EC Commission, Judgment of the Court of First Instance of 5 March 1997, [1997] ECR II-313', 35 Common Market Law Review 189.

The Council of the European Union (2003), Council Annual Report on Access to Documents - 2002 (Brussels: the Council), available at: http://register.consilium.eu.int/utfregister/frames/introfsEN.htm

- - (2004), Council Annual Report on Access to Documents - 2003 (Brussels: the Council), available at:

http://ue.eu.int/uedocs/cmsUpload/RapAnCons.en03.pdf

Craig, P., and de Búrca, G. (2002), EU Law: Text, Cases, and Materials (Oxford: Oxford University Press).

Craig, P., and Rawlings, R. (eds.) (2003), Law and Administration in Europe, Essays in Honour of Carol Harlow (Oxford: Oxford University Press).

Curtin, D. (1999), “Civil Society' and the European Union: Opening Spaces for Deliberative Democracy?' in Academy of European law (1999): 185-280.

- - and Meijers, H. (1995), 'Access to European Union Information: an Element of Citizenship and a Neglected Constitutional Right' in Neuwahl and Rosas (1995): 77-104. 
- - (2000), 'Citizens' Fundamental Right of Access to EU Information: an Evolving Digital Passepartout?', 37 Common Market Law Review 7.

- - (2000), 'The "EU Human Rights Charter" and the Union Legal Order: The 'Banns' before the Marriage?' in O'Keeffe and Bavasso (2000): 303-318.

- - (2005), 'Delegation to EU Non-Majoritarian Agencies and Emerging Practices of Public Accountability' in Geradin, Munoz, and Petit (2005): 1-32.

Dashwood, A. (2002), 'Issues of Decision-making in the European Union after Nice' in Arnull and Wincott (2002): 13-40.

- - and Ward, A. (eds.) (2000), Cambridge Yearbook of European Legal Studies vol. 2 (Oxford: Hart Publishing).

Davis, R. (1999), 'Public Access to Community Documents: a Fundamental Human Right?', 3(8) European Integration Online Papers, available at: http://eiop.or.at/eiop/texte/1999-008.htm

- (2001) 'Quasi-Judicial Review: the European Ombudsman as an Alternative to the European Courts', 1 Web Journal of Current Legal Issues, available at: http://webjcli.ncl.ac.uk/2000/issue1/davis1.html

De Búrca, G. (1993), 'The Principle of Proportionality and its Application in EC Law' in Barav and Wyatt (1993): 105-150.

De Leeuw, M. (1997), 'WWF (UK) v. Commission of the European Communities', 3 European Public Law 339.

Deckmyn, V., and Thompson, I. (eds.) (1998), Openness and Transparency in the European Union (Maastricht: European Institute of Public Administration).

Dinan, D. (1999), Ever Closer Union? An Introduction to the European Integration, $2^{\text {nd }}$ edn. (Basingstoke: Macmillan).

__ (2003), 'How Did We Get Here?' in Bomberg and Stubb (2003): 19-39. 
Dixon, M., and McCorquodale, R., (2000), Cases and Materials on International Law, $3^{\text {rd }}$ edn. (London: Blackstone Press).

Dobson, L., and Weale, A. (2003), 'Government and Legitimacy,' in Bomberg and Stubb (2003): 156-173.

Douglas-Scott, S. (2002), Constitutional Law of the European Union (Essex: Longman).

Dyrberg, P. (1999), 'Current Issues in the Debate on Public Access to Documents', 24 European Law Review 157.

- - (2002), 'Accountability and Legitimacy: What is the Contribution of Transparency?' in Arnull and Wincott (2002): 81-96.

Edward, D. (2005), 'Thinking about Constitutions', The Federal Trust European Essay No. 34, available at: http://www.fedtrust.co.uk/default.asp?groupid=8

Ellis, E. (ed.) (1999), The Principle of Proportionality in the Laws of Europe (Oxford: Hart Publishing).

The European Commission (1993), Public Access to the Institutions' Documents (Communication to the Council, the Parliament and the Economic and Social Committee) [1993] OJ C156/5.

-.. (2003), Report from the Commission on the Application in 2002 of Regulation (EC) No 1049/2001 of the European Parliament and of the Council regarding Public Access to European Parliament, Council and Commission documents, $\operatorname{COM}(2003) 216$ final, (Brussels: European Commission), available at: http://europa.eu.int/smartapi/cgi/sga_doc?smartapi!celexapi!prod!CELEXn umdoc\&lg=EN\&numdoc $=$ 52003DC0216\&model=guichett

- - (2003), How the European Union Works, a Citizen's Guide to the EU Institutions (Brussels: European Commission).

- (2004), Report from the Commission on the Implementation of the principles in EC Regulation No 1049/2001 regarding Public Access to European Parliament, 
Council and Commission Documents, COM(2004) 45 final, (Brussels: European Commission), available at:

http://europa.eu.int/eur-lex/en/com/rpt/2004/com2004_0045en01.pdf

- (2004), Report from the Commission on the Application in 2003 of Regulation (EC) No 1049/2001 regarding Public Access to European Parliament, Council and Commission documents, $\mathrm{COM}(2004) 347$ final, (Brussels: European

Commission), available at:

http://europa.eu.int/eur-lex/lex/LexUriServ/site/en/com/2004/com2004_0347e n01.pdf

The European Data Protection Supervisor (2005), Public Access to Documents and Data Protection, Background Paper Series Number 1 (Brussels: European Data Protection Supervisor).

The European Economic and Social Committee (2005), The EESC in Ten Points (Brussels: European Economic and Social Committee).

The European Ombudsman (1998), The European Ombudsman Annual Report for 1997 (Strasbourg: European Ombudsman).

- - (2000), Ombudsman calls for a fundamental right to an open, accountable and service-minded administration Press Release 3/2000 (02 February 2000), available at: http://www.euro-ombudsman.eu.int/release/en/charter1.htm

- - (2002), What can the European Ombudsman Do for You (Luxembourg: European Ombudsman).

- (2002), Special Report from the European Ombudsman to the European Parliament following the draft recommendation to the European Parliament in complaint 341/2001/(BB)IJH (Luxembourg: European Ombudsman).

- - (2002), Special Report from the European Ombudsman to the European Parliament following the draft recommendation to the Council of the European Union in complaint 1542/2000/(PB)SM (Luxembourg: European Ombudsman).

- (2003), The European Ombudsman, Annual Report 2002 (Luxembourg: 
Publications Office).

- - (2004), The European Ombudsman, Annual Report 2003 (Luxembourg: Publications Office).

- - (2004), Special Report from the European Ombudsman to the European Parliament following the draft recommendation to the European Commission in own-initiative inquiry OI/2/2003/GG (Luxembourg: European Ombudsman).

The European Parliament (2003), Review of the Implementation within the European Parliament of Regulation (EC) 1049/2001, PE 324.892/BUR, (Strasbourg: European Parliament).

- (2003), Report on Public Access to Parliament, Council and Commission Documents (Implementation of Regulation 1049/2001/EC in the year 2002) (2003/2022(INI)), Final A5-0298/2003, (Strasbourg: European Parliament).

The European Union (2002), Access to European Parliament, Council and Commission Documents, A User's Guide (Luxembourg: Publications Office).

Forwood, N. (2003), 'The Judicial Architecture of the European Union - the Challenges of Change' in Hoskins and Robinson (2003): 81-90.

Frost, A. (2003), 'Restoring Faith in Government: Transparency Reform in the United States and the European Union', 9 European Public Law 96.

Geradin, D., Munoz, R., and Petit, N. (eds.) (2005), Regulation through Agencies: $a$ New Paradigm of European Governance (Cheltenham Glos: Edward Elgar Publishing).

Goldberg, D., Prosser, T., and Verhulst, S. (1998), EC Media Law and Policy (Essex: Longman).

Harden, I. (2001), 'Citizenship and Information', 7 European Public Law 165.

Harlow, C. (2000), 'Freedom of Information and Transparency as Administrative and Constitutional Rights' in Dashwood and Ward (2000): 285-302. 
- (2002), Accountability in the European Union (Oxford: Oxford University Press).

Hartley, T. (1999), Constitutional Problems of the European Union (Oxford: Oxford University Press).

- - (2003), The Foundations of European Community Law, $5^{\text {th }}$ edn. (Oxford: Oxford University Press).

- (2004), European Union Law in a Global Contcxt, Texts, Cases and Materials (Cambridge: Cambridge University Press).

Hayes-Renshaw, F. (2002), 'The Council of Ministers' in Peterson and Shackleton (2002): 47-70.

Herlitz, N. (1958), 'Publicity of Official Documents in Sweden', Public Law 50.

Hoskins, M., and Robinson, W. (2003), A True European, Essays for Judge David Edward (Oxford: Hart Publishing).

Hoskyns, C. (2000), 'Democratizing the EU: Evidence and Argument' in Hoskyns and Newman (2000).

- - and Newman, M. (eds.) (2000), Democratizing the European Union, Issues for the Twenty-First Century (Manchester: Manchester University Press).

The House of Lords Select Committee on the European Union, HL Report of the Select Committee on European Union: Public Access to EU Documents (HL Report (2000) No 16), available at:

http://www.parliament.the-stationery-office.co.uk/pa/ld199900/Idselect/ldeuc om/102/10205.htm

- HL Report of the Select Committee on European Union: Public Access to Documents: The Council Decision of 14 August 2000 (HL Report (2001) No 8), available at:

http://www.parliament.the-stationery-office.co.uk/pa/ld200001/Idselect/ldeuc om/31/3101.htm 
Hurwitz, L., and Lequesne, C. (eds.) (1991), The State of the European Community: Policies, Institutions, and Debates in the Transition Years (Boulder: Lynne Rienner).

Jacobs, F. (1999), 'Recent Developments in the Principle of Proportionality in European Community Law' in E. Ellis (1999): 1-21.

Joerges, C., and Vos, E. (eds.) (1999), EU Committees: Social Regulation, Law and Politics (Oxford: Hart Publishing).

Klang, M., and Murray, A. (eds.) (2005), Human Rights in the Digital Age (London: The GlassHouse Press).

Mansell, R. (2005), 'Introduction - Human Rights and Equity in Cyberspace' in Klang and Murray (2005): 1-10.

McGoldrick, D. (1997), International Relations Law of the European Union (Esscx: Longman).

Murray, D. (2005), 'Should States Have a Right to Informational Privacy' in Klang and Murray (2005): 191-202.

Neuwahl, N., and Rosas, $\Lambda$. (eds.) (1995), The European Union and Human Rights (The Hague: Martinus Nijhoff).

Nicol, A., Millar, G., and Sharland, A. (eds.) (2001), Media Law \& Human Rights (London: Blackstone Press).

Öberg, U. (1998), 'Public Access to Documents after the Entry into Force of the Amsterdam Treaty: Much Ado about Nothing?', 2(8) European Integration Online Papers, available at: http://eiop.or.at/eiop/texte/1998-008.htm

- - (2000), 'EU Citizens' Right to Know: the Improbable Adoption of A European Freedom of Information Act' in Dashwood and Ward (2000): 303-328.

O'Keeffe, D., and Bavasso, A. (eds.) (2000), Judicial Review in European Union Law (The Hague: Kluwer Law International). 
O'Neill, M. (1998), 'The Right of Access to Community - Held Documentation as a General Principle of EC Law', 4 European Public Law 403.

Örücü, E. (ed.) (2003), Judicial Comparativism in Human Rights Cases (London: The United Kingdom National Committee of Comparative Law).

Österdahl, I. (1998), 'Openness v. Secrecy: Public Access to Documents in Sweden and the European Union', 23 European Law Review 336.

Paraschos, E. (1998), Media Law and Regulation in the European Union, National, Transnational and U.S. Perspectives (Armes: Iowa State University Press).

Peers, S. (2003) 'The European Court of Justice and the European Court of Human Rights: Comparative Approaches' in Örücü (2003): 107-129.

Peterson, J., and Shackleton, M. (eds.) (2002), The Institutions of the European Union (Oxford: Oxford University Press).

Pitt-Payne, T. (2003), 'Privacy Versus Freedom of Information: Is There a Conflict?', Special Issue European Human Rights Law Review 109.

Roberts, A. (2002), 'Multilateral Institutions and the Right to Information: Experience in the European Union', 8 European Public Law 255.

- (2004), 'National Security and Open Government', 9 The Georgetown Public Policy Review 69.

- (2004), 'A Partial Revolution: the Diplomatic Ethos and Transparency in Intergovernmental Organizations', 64 Public Administration Review 408.

- (2005), 'Spin Control and Freedom of Information: Lessons for the United Kingdom from Canada', 83 Public Administration 1.

Schermers, H. (2003), International Institutional Law: Unity within Diversity (Boston: Martinus Nijhoff Publishers).

— - and Waelbrtoeck, D. (1992), Judicial Protection in the Europcan Communitics 
(Deventer: Kluwer Law and Taxation Publishers).

Senden, J. (2004), Soft Law in European Community Law (Oxford: Hart Publishing).

Shaw, J. (2000), Law of the European Union, $3^{\text {rd }}$ edn. (Basingstoke: Palgrave).

Söderman, J. (1997), 'A Thousand and One Complaints: The European Ombudsman en Route', 3 European Public Law 351.

Stubb, A., Wallace, H., and Peterson, J. (2003), 'The Policy-Making Process' in Bomberg and Stubb (2003): 136-155.

Tridimas, T. (1999), 'Proportionality in European Community Law: Searching for the Appropriate Standard of Scrutiny' in E. Ellis (1999): 65-84.

Uhm, K-Y. (2000), The Right to Know: Idealism and Realism in National Security Secrecy (PhD thesis: The University of Iowa).

Urwin, D. (1995), Community of Europe: A History of European Integration Since 1945, $2^{\text {nd }}$ edn. (Essex: Longman).

Usher, J. (1998), General Principles of EC Law (Essex: Longman).

Wallace, H. (1991), 'The Council and the Commission after the Single European Act' in Hurwitz and Lequesne (1991).

_- (2000), 'The Institutional Setting' in Wallace and Wallace (2000).

- - and Wallace, W. (eds.) (2000), Policy-making in the European Union, $4^{\text {th }}$ edn. (Oxford: Oxford University Press).

Zhu, Y. (2000), The Competent Public: A Reexamination of Walter Lippmann's Views on the People's Competence to Know (PhD thesis: University of South Carolina). 


\section{APPENDIX}

Regulation (EC) No 1049/2001 of the European Parliament and of the Council of 30 May 2001 regarding public access to European Parliament, Council and Commission documents

Official Journal L 145, 31/05/2001 P. 0043 - 0048

Regulation (EC) No 1049/2001 of the European Parliament and of the Council of 30 May 2001 regarding public access to European Parliament, Council and Commission documents

\section{THE EUROPEAN PARLIAMENT AND THE COUNCIL OF THE EUROPEAN UNION,}

Having regard to the Treaty establishing the European Community, and in particular Article 255(2) thereof,

Having regard to the proposal from the Commission(1),

Acting in accordance with the procedure referred to in Article 251 of the Treaty(2), Whereas:

(1) The second subparagraph of Article 1 of the Treaty on European Union enshrines the concept of openness, stating that the Treaty marks a new stage in the process of creating an ever closer union among the peoples of Europe, in which decisions are taken as openly as possible and as closely as possible to the citizen.

(2) Openness enables citizens to participate more closely in the decision-making process and guarantees that the administration enjoys greater legitimacy and is more effective and more accountable to the citizen in a democratic system. Openness contributes to strengthening the principles of democracy and respect for fundamental rights as laid down in Article 6 of the EU Treaty and in the Charter of Fundamental Rights of the European Union.

(3) The conclusions of the European Council meetings held at Birmingham, Edinburgh and Copenhagen stressed the need to introduce greater transparency into the work of the Union institutions. This Regulation consolidates the initiatives that the institutions have already taken with a view to improving the transparency of the decision-making process.

(4) The purpose of this Regulation is to give the fullest possible effect to the right of public access to documents and to lay down the general principles and limits on such access in accordance with Article 255(2) of the EC Treaty.

(5) Since the question of access to documents is not covered by provisions of the Treaty establishing the European Coal and Steel Community and the Treaty establishing the European Atomic Energy Community, the European Parliament, the Council and the Commission should, in accordance with Declaration No 41 attached to the Final Act of the Treaty of Amsterdam, draw guidance from this Regulation as regards documents concerning the activities covered by those two Treaties.

(6) Wider access should be granted to documents in cases where the institutions are acting in their legislative capacity, including under delegated powers, while at the same time preserving the effectiveness of the institutions' decision-making process. 
Such documents should be made directly accessible to the greatest possible extent. (7) In accordance with Articles 28(1) and 41(1) of the EU Treaty, the right of access also applies to documents relating to the common foreign and security policy and to police and judicial cooperation in criminal matters. Each institution should respect its security rules.

(8) In order to ensure the full application of this Regulation to all activities of the Union, all agencies established by the institutions should apply the principles laid down in this Regulation.

(9) On account of their highly sensitive content, certain documents should be given special treatment. Arrangements for informing the European Parliament of the content of such documents should be made through interinstitutional agreement. (10) In order to bring about greater openness in the work of the institutions, access to documents should be granted by the European Parliament, the Council and the Commission not only to documents drawn up by the institutions, but also to documents received by them. In this context, it is recalled that Declaration No 35 attached to the Final Act of the Treaty of Amsterdam provides that a Member State may request the Commission or the Council not to communicate to third parties a document originating from that State without its prior agreement.

(11) In principle, all documents of the institutions should be accessible to the public. However, certain public and private interests should be protected by way of exceptions. The institutions should be entitled to protect their internal consultations and deliberations where necessary to safeguard their ability to carry out their tasks. In assessing the exceptions, the institutions should take account of the principles in Community legislation concerning the protection of personal data, in all areas of Union activities.

(12) All rules concerning access to documents of the institutions should be in conformity with this Regulation.

(13) In order to ensure that the right of access is fully respected, a two-stage administrative procedure should apply, with the additional possibility of court proceedings or complaints to the Ombudsman.

(14) Each institution should take the measures necessary to inform the public of the new provisions in force and to train its staff to assist citizens exercising their rights under this Regulation. In order to make it easier for citizens to exercise their rights, each institution should provide access to a register of documents.

(15) Even though it is neither the object nor the effect of this Regulation to amend national legislation on access to documents, it is nevertheless clear that, by virtue of the principle of loyal cooperation which governs relations between the institutions and the Member States, Member States should take care not to hamper the proper application of this Regulation and should respect the security rules of the institutions. (16) This Regulation is without prejudice to existing rights of access to documents for Member States, judicial authorities or investigative bodies.

(17) In accordance with Article 255(3) of the EC Treaty, each institution lays down specific provisions regarding access to its documents in its rules of procedure. Council Decision 93/731/EC of 20 December 1993 on public access to Council documents(3), Commission Decision 94/90/ECSC, EC, Euratom of 8 February 1994 on public access to Commission documents(4), European Parliament Decision 97/632/EC, ECSC, Euratom of 10 July 1997 on public access to European 
Parliament documents(5), and the rules on confidentiality of Schengen documents should therefore, if necessary, be modified or be repealed,

\section{HAVE ADOPTED THIS REGULATION:}

Article 1

Purpose

The purpose of this Regulation is:

(a) to define the principles, conditions and limits on grounds of public or private interest governing the right of access to European Parliament, Council and Commission (hereinafter referred to as "the institutions") documents provided for in Article 255 of the EC Treaty in such a way as to ensure the widest possible access to documents,

(b) to establish rules ensuring the easiest possible exercise of this right, and

(c) to promote good administrative practice on access to documents.

\section{Article 2}

Beneficiaries and scope

1. Any citizen of the Union, and any natural or legal person residing or having its registered office in a Member State, has a right of access to documents of the institutions, subject to the principles, conditions and limits defined in this Regulation.

2. The institutions may, subject to the same principles, conditions and limits, grant access to documents to any natural or legal person not residing or not having its registered office in a Member State.

3. This Regulation shall apply to all documents held by an institution, that is to say, documents drawn up or received by it and in its possession, in all areas of activity of the European Union.

4. Without prejudice to Articles 4 and 9, documents shall be made accessible to the public either following a written application or directly in electronic form or through a register. In particular, documents drawn up or received in the course of a legislative procedure shall be made directly accessible in accordance with Article 12.

5. Sensitive documents as defined in Article 9(1) shall be subject to special treatment in accordance with that Article.

6. This Regulation shall be without prejudice to rights of public access to documents held by the institutions which might follow from instruments of international law or acts of the institutions implementing them.

Article 3

\section{Definitions}

For the purpose of this Regulation:

(a) "document" shall mean any content whatever its medium (written on paper or stored in electronic form or as a sound, visual or audiovisual recording) concerning a matter relating to the policies, activities and decisions falling within the institution's sphere of responsibility;

(b) "third party" shall mean any natural or legal person, or any entity outside the institution concerned, including the Member States, other Community or nonCommunity institutions and bodies and third countries. 
Article 4

Exceptions

1. The institutions shall refuse access to a document where disclosure would undermine the protection of:

(a) the public interest as regards:

- public security,

- defence and military matters,

- international relations,

- the financial, monetary or economic policy of the Community or a Member State;

(b) privacy and the integrity of the individual, in particular in accordance with

Community legislation regarding the protection of personal data.

2 . The institutions shall refuse access to a document where disclosure would undermine the protection of:

- commercial interests of a natural or legal person, including intellectual property,

- court proceedings and legal advice,

- the purpose of inspections, investigations and audits,

unless there is an overriding public interest in disclosure.

3. Access to a document, drawn up by an institution for internal use or received by an institution, which relates to a matter where the decision has not been taken by the institution, shall be refused if disclosure of the document would seriously undermine the institution's decision-making process, unless there is an overriding public interest in disclosure.

Access to a document containing opinions for internal use as part of deliberations and preliminary consultations within the institution concerned shall be refused even after the decision has been taken if disclosure of the document would seriously undermine the institution's decision-making process, unless there is an overriding public interest in disclosure.

4. As regards third-party documents, the institution shall consult the third party with a view to assessing whether an exception in paragraph 1 or 2 is applicable, unless it is clear that the document shall or shall not be disclosed.

5. A Member State may request the institution not to disclose a document originating from that Member State without its prior agreement.

6. If only parts of the requested document are covered by any of the exceptions, the remaining parts of the document shall be released.

7. The exceptions as laid down in paragraphs 1 to 3 shall only apply for the period during which protection is justified on the basis of the content of the document. The exceptions may apply for a maximum period of 30 years. In the case of documents covered by the exceptions relating to privacy or commercial interests and in the case of sensitive documents, the exceptions may, if necessary, continue to apply after this period.

\section{Article 5}

Documents in the Member States

Where a Member State receives a request for a document in its possession, originating from an institution, unless it is clear that the document shall or shall not be disclosed, the Member State shall consult with the institution concerned in order to take a decision that does not jeopardise the attainment of the objectives of this Regulation. 
The Member State may instead refer the request to the institution.

Article 6

Applications

1. Applications for access to a document shall be made in any written form, including electronic form, in one of the languages referred to in Article 314 of the

EC Treaty and in a sufficiently precise manner to enable the institution to identify the document. The applicant is not obliged to state reasons for the application.

2. If an application is not sufficiently precise, the institution shall ask the applicant to clarify the application and shall assist the applicant in doing so, for example, by providing information on the use of the public registers of documents.

3. In the event of an application relating to a very long document or to a very large number of documents, the institution concerned may confer with the applicant informally, with a view to finding a fair solution.

4. The institutions shall provide information and assistance to citizens on how and where applications for access to documents can be made.

\section{Article 7}

Processing of initial applications

1. An application for access to a document shall be handled promptly. An acknowledgement of receipt shall be sent to the applicant. Within 15 working days from registration of the application, the institution shall either grant access to the document requested and provide access in accordance with Article 10 within that period or, in a written reply, state the reasons for the total or partial refusal and inform the applicant of his or her right to make a confirmatory application in accordance with paragraph 2 of this Article.

2. In the event of a total or partial refusal, the applicant may, within 15 working days of receiving the institution's reply, make a confirmatory application asking the institution to reconsider its position.

3. In exceptional cases, for example in the event of an application relating to a very long document or to a very large number of documents, the time-limit provided for in paragraph 1 may be extended by 15 working days, provided that the applicant is notified in advance and that detailed reasons are given.

4. Failure by the institution to reply within the prescribed time-limit shall entitle the applicant to make a confirmatory application.

\section{Article 8}

Processing of confirmatory applications

1. A confirmatory application shall be handled promptly. Within 15 working days from registration of such an application, the institution shall either grant access to the document requested and provide access in accordance with Article 10 within that period or, in a written reply, state the reasons for the total or partial refusal. In the event of a total or partial refusal, the institution shall inform the applicant of the remedies open to him or her, namely instituting court proceedings against the institution and/or making a complaint to the Ombudsman, under the conditions laid down in Articles 230 and 195 of the EC Treaty, respectively.

2. In exceptional cases, for example in the event of an application relating to a very long document or to a very large number of documents, the time limit provided for in 
paragraph 1 may be extended by 15 working days, provided that the applicant is notified in advance and that detailed reasons are given.

3. Failure by the institution to reply within the prescribed time limit shall be considered as a negative reply and entitle the applicant to institute court proceedings against the institution and/or make a complaint to the Ombudsman, under the relevant provisions of the EC Treaty.

Article 9

Treatment of sensitive documents

1. Sensitive documents are documents originating from the institutions or the agencies established by them, from Member States, third countries or International Organisations, classified as "TRÈS SECRET/TOP SECRET", "SECRET" or "CONFIDENTIEL" in accordance with the rules of the institution concerned, which protect essential interests of the European Union or of one or more of its Member States in the areas covered by Article 4(1)(a), notably public security, defence and military matters.

2. Applications for access to sensitive documents under the procedures laid down in Articles 7 and 8 shall be handled only by those persons who have a right to acquaint themselves with those documents. These persons shall also, without prejudice to Article 11(2), assess which references to sensitive documents could be made in the public register.

3. Sensitive documents shall be recorded in the register or released only with the consent of the originator.

4. An institution which decides to refuse access to a sensitive document shall give the reasons for its decision in a manner which does not harm the interests protected in Article 4.

5. Member States shall take appropriate measures to ensure that when handling applications for sensitive documents the principles in this Article and Article 4 are respected.

6. The rules of the institutions concerning sensitive documents shall be made public.

7. The Commission and the Council shall inform the European Parliament regarding sensitive documents in accordance with arrangements agreed between the institutions.

Article 10

Access following an application

1. The applicant shall have access to documents either by consulting them on the spot or by receiving a copy, including, where available, an electronic copy, according to the applicant's preference. The cost of producing and sending copies may be charged to the applicant. This charge shall not exceed the real cost of producing and sending the copies. Consultation on the spot, copies of less than 20 A4 pages and direct access in electronic form or through the register shall be free of charge.

2. If a document has already been released by the institution concerned and is easily accessible to the applicant, the institution may fulfil its obligation of granting access to documents by informing the applicant how to obtain the requested document.

3. Documents shall be supplied in an existing version and format (including electronically or in an alternative format such as Braille, large print or tape) with full regard to the applicant's preference. 
Article 11

Registers

1. To make citizens' rights under this Regulation effective, each institution shall provide public access to a register of documents. Access to the register should be provided in electronic form. References to documents shall be recorded in the register without delay.

2. For each document the register shall contain a reference number (including, where applicable, the interinstitutional reference), the subject matter and/or a short description of the content of the document and the date on which it was received or drawn up and recorded in the register. References shall be made in a manner which does not undermine protection of the interests in Article 4.

3. The institutions shall immediately take the measures necessary to establish a register which shall be operational by 3 June 2002 .

Article 12

Direct access in electronic form or through a register

1. The institutions shall as far as possible make documents directly accessible to the public in electronic form or through a register in accordance with the rules of the institution concerned.

2. In particular, legislative documents, that is to say, documents drawn up or received in the course of procedures for the adoption of acts which are legally binding in or for the Member States, should, subject to Articles 4 and 9, be made directly accessible.

3. Where possible, other documents, notably documents relating to the development of policy or strategy, should be made directly accessible.

4. Where direct access is not given through the register, the register shall as far as possible indicate where the document is located.

Article 13

Publication in the Official Journal

1. In addition to the acts referred to in Article 254(1) and (2) of the EC Treaty and the first paragraph of Article 163 of the Euratom Treaty, the following documents shall, subject to Articles 4 and 9 of this Regulation, be published in the Official Journal:

(a) Commission proposals;

(b) common positions adopted by the Council in accordance with the procedures referred to in Articles 251 and 252 of the EC Treaty and the reasons underlying those common positions, as well as the European Parliament's positions in these procedures;

(c) framework decisions and decisions referred to in Article 34(2) of the EU Treaty;

(d) conventions established by the Council in accordance with Article 34(2) of the

EU Treaty;

(e) conventions signed between Member States on the basis of Article 293 of the EC Treaty;

(f) international agreements concluded by the Community or in accordance with Article 24 of the EU Treaty.

2. As far as possible, the following documents shall be published in the Official Journal: 
(a) initiatives presented to the Council by a Member State pursuant to Article 67(1)

of the EC Treaty or pursuant to Article 34(2) of the EU Treaty;

(b) common positions referred to in Article 34(2) of the EU Treaty;

(c) directives other than those referred to in Article 254(1) and (2) of the EC Treaty, decisions other than those referred to in Article 254(1) of the EC Treaty, recommendations and opinions.

3. Each institution may in its rules of procedure establish which further documents shall be published in the Official Journal.

Article 14

Information

1. Each institution shall take the requisite measures to inform the public of the rights they enjoy under this Regulation.

2. The Member States shall cooperate with the institutions in providing information to the citizens.

Article 15

Administrative practice in the institutions

1. The institutions shall develop good administrative practices in order to facilitate the exercise of the right of access guaranteed by this Regulation.

2. The institutions shall establish an interinstitutional committee to examine best practice, address possible conflicts and discuss future developments on public access to documents.

Article 16

Reproduction of documents

This Regulation shall be without prejudice to any existing rules on copyright which may limit a third party's right to reproduce or exploit released documents.

Article 17

Reports

1. Each institution shall publish annually a report for the preceding year including the number of cases in which the institution refused to grant access to documents, the reasons for such refusals and the number of sensitive documents not recorded in the register.

2. At the latest by 31 January 2004 , the Commission shall publish a report on the implementation of the principles of this Regulation and shall make recommendations, including, if appropriate, proposals for the revision of this Regulation and an action programme of measures to be taken by the institutions.

\section{Article 18}

Application measures

1. Each institution shall adapt its rules of procedure to the provisions of this Regulation. The adaptations shall take effect from 3 December 2001.

2. Within six months of the entry into force of this Regulation, the Commission shall examine the conformity of Council Regulation (EEC, Euratom) No 354/83 of 1 February 1983 concerning the opening to the public of the historical archives of the European Economic Community and the European Atomic Energy Community (6) 
with this Regulation in order to ensure the preservation and archiving of documents to the fullest extent possible.

3. Within six months of the entry into force of this Regulation, the Commission shall examine the conformity of the existing rules on access to documents with this Regulation.

Article 19

Entry into force

This Regulation shall enter into force on the third day following that of its publication in the Official Journal of the European Communities.

It shall be applicable from 3 December 2001.

This Regulation shall be binding in its entirety and directly applicable in all Member States.

Done at Brussels, 30 May 2001.

For the European Parliament

The President

N. Fontaine

For the Council

The President

B. Lejon

(1) OJ C 177 E, 27.6.2000, p. 70.

(2) Opinion of the European Parliament of 3 May 2001 (not yet published in the Official Journal) and Council Decision of 28 May 2001.

(3) OJ L 340, 31.12.1993, p. 43. Decision as last amended by Decision 2000/527/EC (OJ L 212, 23.8.2000, p. 9).

(4) OJ L 46, 18.2.1994, p. 58. Decision as amended by Decision 96/567/EC, ECSC, Euratom (OJ L 247, 28.9.1996, p. 45).

(5) OJ L 263, 25.9.1997, p. 27.

(6) OJ L 43, 15.2.1983, p. 1. 